UNIVERSIDADE DE SÃO PAULO

FACULDADE DE ECONOMIA, ADMINISTRAÇÃO E CONTABILIDADE

DEPARTAMENTO DE CONTABILIDADE E ATUÁRIA

PROGRAMA DE PÓS-GRADUAÇÃO EM CONTROLADORIA E CONTABILIDADE

SAMIR SAYED

Financial reporting como instrumento ideológico para fins hegemônicos: evidências do Banco do Brasil (1853 - 1902) 

Prof. Dr. Marco Antônio Zago

Reitor da Universidade de São Paulo

Prof. Dr. Adalberto Américo Fischmann

Diretor da Faculdade de Economia, Administração e Contabilidade

Prof. Dr. Gerlando Augusto Sampaio Franco de Lima

Chefe do Departamento de Contabilidade e Atuária

Prof. Dr. Luiz Paulo Lopes Fávero

Coordenador do Programa de Pós-Graduação em Controladoria e Contabilidade 


\section{SAMIR SAYED}

Financial reporting como instrumento ideológico para fins hegemônicos: evidências do Banco do Brasil (1853 - 1902)

Tese de Doutorado apresentada ao Departamento de Contabilidade e Atuária da Faculdade de Economia, Administração e Contabilidade da Universidade de São Paulo como parte dos requisitos para a obtenção do grau de Doutor em Ciências.

Área de concentração:

Controladoria e Contabilidade

Orientador:

Prof. Dr. Edgard Cornacchione Júnior

Versão original 
Autorizo a reprodução e divulgação total ou parcial deste trabalho, por qualquer meio convencional ou eletrônico, para fins de estudo e pesquisa, desde que citada a fonte.

FICHA CATALOGRÁFICA

Elaborada pela Seção de Processamento Técnico do SBD/FEA/USP

Sayed, Samir.

Financial reporting como instrumento ideológico para fins hegemônicos: evidências do Banco do Brasil (1853-1902) / Samir Sayed. -- São Paulo, 2016.

$228 \mathrm{p}$.

Tese (Doutorado) - Universidade de São Paulo, 2016.

Orientador: Edgard Cornacchione Júnior.

1. Contabilidade - História 2. Hegemonia 3. Ideologia 4. História do Brasil I. Universidade de São Paulo. Faculdade de Economia, Administração e Contabilidade II. Título.

CDD -657.09 
Dedico minha tese aos meus pais (Omar Sayed e Vilma Bock Sayed), meu avô (Sayed Abdul Ghani, in memoriam) e minha tia (Fátima Sayed Ghani, in memoriam). 



\section{AGRADECIMENTOS}

Inicialmente gostaria de agradecer aos meus pais (Omar e Vilma) por me ensinarem o valor do conhecimento e do estudo. Mãe: aquelas noites passando os cadernos a limpo não foram em vão. Pode ter certeza. Serei eternamente grato.

Também gostaria de deixar aqui o meu sincero agradecimento ao Professor Dr. Edgard Bruno Cornacchione que aceitou o imenso desafio que essa tese nos representou. Bem como ao estimado Prof. Dr. Alan Sangster, que teve a missão de ser coorientador nesse projeto.

Também queria deixar minhas homenagens a todos os professores do programa, tanto os que tive o prazer de ter aulas, como aqueles que encontramos apenas no corredor. Em especial aos Prof. Dr. Gilberto Martins, Prof. Dr. Eliseu Martins, Prof. Dr. David Carter, bem como aqueles professores de outras unidades da USP, que tive o privilégio de ter aulas, como a Prof. Dra. Carmen Sylvia Vidigal Moraes da FE-USP e seu conhecimento vasto dos conceitos de Gramsci.

Não poderia deixar de mencionar meus queridos alunos da Fipecafi, FBM e UNIFESP, em especial às "gêmeas siamesas" Julia Alonso e Luna Romeu da UNIFESP (Juna) que tanto me ajudaram com a confecção dessa longuíssima base de dados. 

A realidade é meramente uma ilusão, apesar de ser uma ilusão bem persistente.

\section{Albert Einstein}





\section{RESUMO}

Sayed, S. (2016). Financial reporting como instrumento ideológico para fins hegemônicos: evidências do Banco do Brasil (1853 - 1902). Tese de Doutorado, Faculdade de Economia, Administração e Contabilidade, Universidade de São Paulo.

O objetivo central do nosso estudo é evidenciar e entender como o poder dominante brasileiro se apoderou do financial reporting e da contabilidade em si como instrumento ideológico e consequentemente de controle hegemônico, através da criação de uma realidade que satisfaça seus interesses materiais. A unidade de estudo é o Banco do Brasil entre 1853 e 1902, fase de muitas mudanças sociais, econômicas e políticas no país. Baseando-se na abordagem crítica, em um estudo de caráter histórico através de pesquisa documental primária, utilizamos a plataforma teórica do marxista italiano Antonio Gramsci (1891-1937) em suas definições de hegemonia e ideologia, sobretudo. Os documentos foram analisados em duas frentes. A primeira se refere ao discurso empregado. A segunda, estudamos questões contábeis específicas, sobretudo o cálculo do lucro e a distribuição de dividendos. As conclusões apontam que o Banco do Brasil ao longo do período áureo da produção cafeeira nacional foi utilizado pelo poder dominante, apoderado do Estado, para a transferência de recursos para a burguesia, contribuindo de maneira importante para a desigualdade econômica e social em nosso país. Especificamente, em primeiro, através a interface entre sociedade civil e sociedade política no seio do Estado Brasileiro durante o período estudado. Em segundo lugar, analisamos o vínculo orgânico entre a estrutura e a superestrutura no Brasil e os efeitos para os beneficiados. São evidenciados, sobretudo, a questão dos conflitos entre intelectuais orgânicos e os tradicionais e as ações da classe dominante para manter a ideologia do mesmo grupo. Adicionalmente, a tentativa de transformismo do intelectual rural e de algumas classes subalternas e por fim, o abandono das regiões e classes desfavorecidas. Defendemos, pois, que o financial reporting e a contabilidade são instrumentos de disseminação e controle ideológico, mas ao conterem essas características, evidenciam adicionalmente as contradições do sistema capitalista-burguês.

Palavras-chave: história da contabilidade, hegemonia, ideologia, história do Brasil. 


\begin{abstract}
Sayed, S. (2016). Financial reporting as ideological instrument for hegemonical purposes: evidences of Banco do Brasil (1853 - 1902). PhD Thesis. Faculdade de Economia, Administração e Contabilidade, Universidade de São Paulo.
\end{abstract}

The central objective of our study is to demonstrate and analyze how the Brazilian ruling group took over the financial reporting and accounting itself as an ideological instrument and consequently of hegemonic control, by creating a reality that satisfies their material interests. The study unit is the Banco do Brazil between 1853 and 1902, period of many changes in social, economic and politics in the country. Based on the critical approach, in a historical cstudy through primary documentary research, we use the theoretical platform of the marxist italian, Antonio Gramsci (1891-1937) in its hegemonic definitions and ideology, especially. The documents were analyzed on two fronts. The first one relates to the discourse employed. The second one analyzes specific accounting issues, especially the income calculation and the dividends distribution. The findings suggest that the Banco do Brasil during the golden period of national coffee production was used by the ruling group, seized by the state, for transferring resources to the bourgeoisie, contributing significantly to the economic and social inequality in our country. Specifically, first, through the interface between civil society and political society within the Brazilian State during the period studied. Secondly, we show the direct relationship between the structure and the superstructure in Brazil and the effects for the beneficiaries. We evidence, above all, the issue of conflicts between organic intellectuals and the traditional ones and the actions of the ruling class to keep the ideology of that group. Additionally, attempting to transform the rural intelectual and some subaltern classes and finally the abandonment of poor regions and disadvantaged classes. Our position, therefore, is that the financial reporting and accounting are used as ideological controlling tool, but by containing these characteristics additionally, they show the contradictions of bourgeois-capitalist system.

Keywords: accounting history, hegemony, ideology, Brazilian history. 


\section{LISTA DE TABELAS}

Tabela 1 - Exportação de café entre 1857 e 1869 (em 1 milhão de sacas) ................51

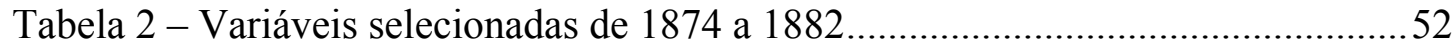

Tabela 3 - Lucro e relação com capital effectivo ......................................................... 113

Tabela 4 - Efeitos da remuneração dos diretores na rentabilidade, constituição de fundo de reserva e distribuição de dividendos para os anos bancais de 1850 (em réis-mil)

Tabela 5 - Efeitos da remuneração dos diretores na rentabilidade, constituição de fundo de reserva e distribuição de dividendos para os anos bancais de 1860 (em réis-mil)

Tabela 6 - Efeitos da remuneração dos diretores na rentabilidade, constituição de fundo de reserva e distribuição de dividendos para os anos bancais de 1870 (em réis-mil)

Tabela 7 - Efeitos da remuneração dos diretores na rentabilidade, constituição de fundo de reserva e distribuição de dividendos para os anos bancais de 1880 (em réis-mil)

Tabela 8 - Efeitos da remuneração dos diretores na rentabilidade, constituição de fundo de reserva e distribuição de dividendos para os anos bancais de 1890 a 1893 (em réis-mil)

Tabela 9 - Efeitos da contabilização do fundo de reserva no patrimônio na rentabilidade e distribuição de dividendos para os anos bancais de 1850 (em réis-mil)

Tabela 10 - Efeitos da contabilização do fundo de reserva no patrimônio na rentabilidade e distribuição de dividendos para os anos bancais de 1860 (em réis-mil)

Tabela 11 - Efeitos da contabilização do fundo de reserva no patrimônio na rentabilidade e distribuição de dividendos para os anos bancais de 1870 (em réis-mil)

Tabela 12 - Efeitos da contabilização do fundo de reserva no patrimônio na rentabilidade e distribuição de dividendos para os anos bancais de 1880 (em réis-mil)

Tabela 13 - Efeitos da contabilização do fundo de reserva no patrimônio na rentabilidade e distribuição de dividendos para os anos bancais de 1890 a 1900 (em réis-mil)

Tabela 14 - A distribuição de dividendos comparando os números reais e ajustados nos anos de 1850 (em réis-mil)

Tabela 15 - A distribuição de dividendos comparando os números reais e ajustados nos anos de 1860 (em réis-mil)

Tabela 16 - A distribuição de dividendos comparando os números reais e ajustados nos anos de 1870 (em réis-mil) 208

Tabela 17 - A distribuição de dividendos comparando os números reais e ajustados nos anos de 1880 (em réis-mil) 
Tabela 18 - A distribuição de dividendos comparando os números reais e ajustados nos anos de 1890 a 1900 (em réis-mil) ...................................................211

Tabela 19 - Os efeitos da distribuição de dividendos no Banco do Brasil (1853 -

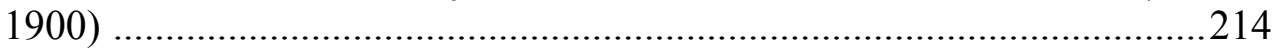




\section{LISTA DE QUADROS}

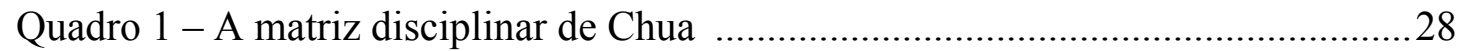

Quadro 2 - As premissas da pesquisa mainstream em contabilidade ........................32

Quadro 3 - As premissas da pesquisa interpretativista em contabilidade ...................34

Quadro 4 - As premissas da pesquisa crítica em contabilidade ..................................37

Quadro 5 - Os ciclos do período pré-intervenção oficial $(1857$ - 1906)......................50

Quadro 6 - Os diversos Bancos do Brasil ..................................................................63 


\section{LISTA DE FIGURAS}

Figura1 - Produção de café no Brasil durante o século XIX .......................................48

Figura 2 - Preço de importação do café nos EUA entre 1850 e 1890 .........................49 


\section{LISTA DE SIGLAS}

BB: Banco do Brasil

EUA: Estados Unidos da América

MA: Maranhão

PA: Pará 



\section{SUMÁRIO}

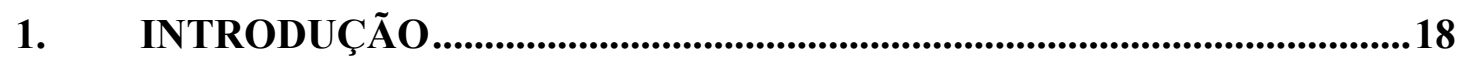

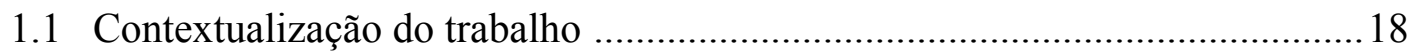

1.2 Contextualização epistemológica e ontológica …………………………….......26

1.3 Críticas ao paradigma atual e o porquê das premissas ontológicas e epistemológicas adotadas nessa pesquisa …………………………...................... 30

1.4 Objetivos, objeto e método de análise …………………….............................39

2. REFERENCIAL TEÓRICO...................................................................46

2.1 Mudanças econômicas e sociais no Brasil a partir do século XIX ………….....46

2.2 Uma breve história do Banco do Brasil e suas relações com as sociedades

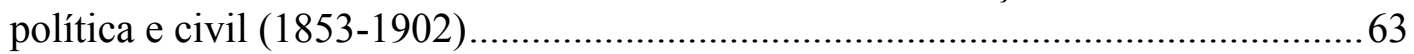

2.3 As principais ideias de Antonio Gramsci.......................................................

3. FINANCIAL REPORTING COMO INSTRUMENTO DE DISSEMINAÇÃO IDEOLÓGICA: ELEMENTOS DO DISCURSO .....................96

$3.1 \mathrm{O}$ vínculo entre a estrutura e a superestrutura.................................................97

3.1a O café como símbolo do bem público ……………………………......98

3.1b Abandono das regiões desfavorecidas: o contraste com as regiões mais

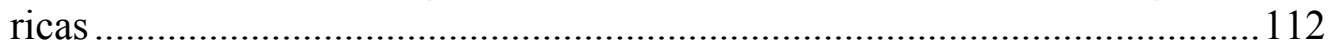

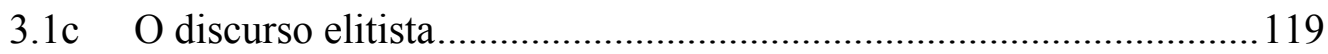

3.1d A questão dos meios de produção: o trabalho escravo …………….....127

3.2 Interface entre sociedade civil e sociedade política no seio do Estado Brasileiro ...............................................................................................132

3.2a Interesse público ou privado: operações e troca de favores entre o banco e o(s) governo(s) ..........................................................................133

3.2b A visão sobre as revoltas no país ………………………………........161

3.2c Transição do regime político: do Império para a República Militar e da República Militar para a República Oligárquica ............................................166

4. FINANCIAL REPORTING COMO INSTRUMENTO DE DISSEMINAÇÃO IDEOLÓGICA: ELEMENTOS CONCEITUAIS

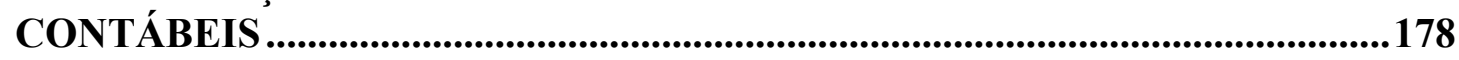

4.1 A definição de lucro e a remuneração dos diretores .........................................181

4.2 A principal despesa de um banco: os títulos duvidosos.................................190

4.3 A nefasta distribuição do público para o privado ...........................................203

5. CONSIDERAÇÕES FINAIS E CONCLUSÕES.....................................212

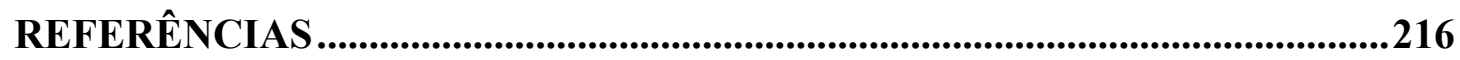





\section{CAPÍTULO 1 - INTRODUÇÃO}

\section{1 - CONTEXTUALIZAÇÃO DO TRABALHO}

O mundo do século XVIII foi marcado por grandes transformações, tais como a Revolução Francesa e a consolidação de regimes democráticos na Europa, além de um enfraquecimento contínuo do poder da Igreja, tendo a ciência um papel cada vez mais fundamental na vida das pessoas. (Hobsbawn, 2005)

No início dos XIX, Napoleão Bonaparte forçava Portugal a aderir ao bloqueio continental, em que deveria declarar guerra à Inglaterra. Outras consequências desta retaliação eram o fechamento dos portos aos navios ingleses, a prisão de seus cidadãos residentes em terras lusitanas, além do confisco de seus bens. Mas Portugal resistia à pressão francesa, já que era dependente economicamente dos ingleses, seus principais consumidores e financiadores à época. Napoleão marchava rapidamente em território espanhol: a situação de Portugal era alarmante, dado que a pujança econômica já não era aquela da época da expansão ultramarina dos séculos XVI a XVIII. Uma decisão era urgente. A família real e a corte deveriam abandonar a Europa. E assim o fizeram; chegaram ao Brasil em 24 de janeiro de 1808. E trouxeram consigo grandes inovações para a colônia - uma delas, a criação do Banco do Brasil em 12 de outubro de 1808, sendo considerado o banco central da província, tendo como objetivos principais, a confecção de moeda e a indução do desenvolvimento da parca indústria nacional da época. (Furtado, 2007; Ribeiro, 2009).

Durante o século XIX o Brasil viveu um de seus períodos de maiores mudanças sociais, políticas e econômicas, decorrentes da instalação da corte portuguesa no país em 1808. Assistimos a muitos eventos marcantes, como a independência, a mudança da nossa monocultura de exportação (café), toda a injustiça com os escravos oficialmente abolida, embora não na prática, a mudança de regime político, o início das atividades industriais, etc. Mas a sociedade em geral permanece privada de toda a riqueza gerada no período e alienada a um modo de produção nos dias mais primeiros do capitalismo no Brasil.

O ambiente sócio-político também passou por grandes transformações neste período, como a institucionalização dos impérios (1822 a 1889), a independência em relação à metrópole (1822), a abolição da escravatura (1888) e culminando com a proclamação 
da República (1889), a República Militar (1889-1894) e a República Oligárquica, finda somente em 1930. Porém não há como negar o chavão da época Imperial e primeiras décadas da República: O Brasil era o café e o café era o Brasil!

Ainda baseado no modelo agroexportador, a economia brasileira começa a apresentar seus primeiros sinais de diversificação e industrialização, como por exemplo, na produção do charque no sul do país e o desenvolvimento da cultura de algodão e da indústria têxtil, a fim de fornecer tecidos para a Inglaterra. Como afirma Caio Prado Jr. (2012), embora as primeiras mudas da planta tenham surgido na porção norte e nordeste de nosso país, é durante o século XIX, que o eixo se descola para o SudesteSul, mais notadamente após a segunda metade.

Na visão de Celso Furtado (2007), o desenvolvimento da produção do referido gênero na região próxima a capital federal se deu devido a abundância de mão-de-obra, oriunda da desagregação das minas, à proximidade do porto, solucionando o problema de transporte: enfim, nessa primeira fase da expansão do café, a sua expansão se deu por aproveitamento de recursos já existentes e subutilizados. Furtado (2007) aponta que nessa fase ocorre a formação de uma nova classe empresária nacional, que "desde cedo ... compreenderam a enorme importância que podia ter o governo como instrumento de ação econômica.” (p. 170).

Holanda (1995) coloca a interface da importância agrícola na formação da sociedade nacional:

(...) a rigor uma civilização agrícola o que os portugueses instauraram no Brasil, foi, sem dúvida, uma civilização de raízes rurais. É efetivamente nas propriedades rústicas que toda a vida da colônia se con centra durante os séculos iniciais da ocupação européia: as cidades são virtualmente, se não de fato, simples dependências delas. Com pouco exagero pode dizer-se que tal situação não se modificou es sencialmente até à Abolição. 1888 representa o marco divisório en tre duas épocas; em nossa evolução nacional, essa data assume significado singular e incomparável. $\mathrm{Na}$ Monarquia eram ainda os fazendeiros escravocratas e eram filhos de fazendeiros, educados nas profissões liberais, quem monopolizava a política, elegendo-se ou fazendo eleger seus candidatos, dominando os parlamentos, os ministérios, em geral todas as posi ções de mando, e fundando a estabilidade das instituições nesse incontestado domínio. (p. 73) 
Em relação à intermediação financeira, até a vinda da família real ao Brasil, a dinâmica do crédito no país era efetuada por capitalistas ingleses e brasileiros, que efetuavam a captação de recursos em terras nacionais e enviavam à Europa a fim de convertê-los em títulos de renda. (Banco do Brasil, 2010). A escassez de moeda tanto nacional quanto externa (libras e dólares) são a tônica em todo nosso período de pesquisa.

Andrada (1923) abordou a questão monetária em quatro fases históricas em nosso país. A primeira iniciada ainda em tempos coloniais com a fundação do Banco do Brasil em 1808, com os bilhetes bancários inicialmente conversíveis em moeda metálica, ficaram posteriormente inconversíveis, devido à emissão desordenada, circulando até 1829, quando foram encampados pelo Estado. A segunda, iniciada com a fundação do Banco do Brasil (emissor) em 1853, com o privilégio de ser único emissor até 1857, ampliando-se a pluralidade até 1860, ano em que após dura regulamentação legal, aqueles bancos emissores de outrora deixaram de existir, com o Banco do Brasil sendo o único habilitado a emissão, novamente perdida em 1866, que por força de lei começou a ser apenas um banco de descontos e depósitos. Já a terceira fase, iniciou-se em 1889 ainda no Império, com, inicialmente, pluralidade de bancos emissores e conversibilidade dos bilhetes em ouro, depois pluralidade porém com inconversilidade das notas, tendo apenas como lastro apólices da dívida pública ou metal e, por fim, a unidade na emissão, porém com bilhetes inconversíveis. Em 1896, os bilhetes circulantes passaram às mãos do Tesouro, sendo substituídos por notas por ele emitidas, encampadas pelo Estado Republicano. E, por fim, a quarta fase com início em 1921 com a fundação da carteira de emissão e redesconto do Banco do Brasil. Vejamos que boa parte da história monetária e financeira do país se confunde com a própria história da nossa unidade de estudo.

O Banco do Brasil (BB) fundado em 1808 com a chegada da família real lusa em terras nacionais e ainda de presença relevante nos dias atuais sempre teve em sua missão agir em prol do interesse público, contribuindo de maneira direta para o desenvolvimento econômico e social do país.

Porém dentro da dinâmica capitalista, qual seria esse interesse público? O que é desenvolvimento econômico e social? 
A unidade de nosso estudo (BB) é uma instituição curiosa no momento que desde os seus primórdios é uma entidade de capital misto, sendo controlada (de fato não de direito) pelo Estado, que detinha alguns privilégios em relação à referida instituição, já que os estatutos da mesma estipulavam que o governo central tinha poderes para apontar presidente e vice-presidente, bem como solicitar operações com o banco (muitas vezes em condições bem vantajosas) como a dividindo as demais ações, inicialmente com a burguesia portuguesa, nos primeiros anos de sua conturbada existência; brasileira num segundo momento (mais notadamente após a sua fundação de 1853) e globalizada num terceiro instante (com a dinâmica da globalização crescente no terceiro quarto do século $\mathrm{XX}$ ): curiosa, pois ao mesmo tempo é sociedade civil e sociedade política, numa visão gramscista, como abordaremos mais a frente.

\section{O objetivo dessa pesquisa é entender através de uma abordagem gramsciana} como o Banco do Brasil, entidade representante da união entre sociedade civil e sociedade política brasileira, utilizou-se do financial reporting como instrumento de disseminação ideológica do grupo dominante entre 1853 e 1902.

Ou seja, pretendemos contar a história na visão daqueles que tem o poder de criar a história, modelando-a em seu interesse.

Como plataforma teórica, utilizaremos a contribuição do intelectual marxista italiano Antonio Gramsci (1891-1937) e sua concepção de hegemonia e ideologia.

Gramsci trabalhou ativamente como jornalista de esquerda inclusive dentro do Partido Comunista Italiano, sendo inclusive uma de suas lideranças desde a fundação. Secco (2006) destaca que o período compreendido entre 1921 e 1926 é uma "fase de transição entre o jovem Gramsci, esperançoso na Revolução Mundial e aquele teórico do cárcere que meditará sobre porque a revolução foi derrotada no Ocidente.” (p. 107).

Nos anos 20 o fascismo ganha força e em 1926 é preso pela polícia italiana. Fiori (1979) bem destaca:

Quando em 2 de junho de 1928 o Ministério Público tomou a palavra no processo contra Antonio Gramsci e outros líderes do Partido Comunista dÍtalia (PCD'I) presos com ele, uma violenta exposição de motivos condenando-o foi proferida. Sobre Gramsci, o 
pronunciamento expôs sua total irracionalidade: por vinte anos devemos impedir que este cérebro funcione. (p. 285)

Bianchi (2008) apontou uma das cartas trocadas entre o encarcerado e sua cunhada, Tatiana, afirmando que era necessário fazer algo für ewig (para sempre), assim como dizia Goethe.

Durante sua estadia no cárcere, de 1926 até 1937, ano de sua morte, sua obra de maior destaque foi compilada, não como um livro único, um projeto com começo, meio e fim, muito devido às condições precárias de saúde do autor: a condição no cárcere que o impedia a ter uma biblioteca para melhor referenciar seu trabalho, bem como ter apenas cadernos escolares, que totalizaram 33 e após algumas edições e coletâneas, além do esforço grande da cunhada de Gramsci e demais membros do Partido Comunista em levar os cadernos em segurança para Moscou, chegou-nos o clássico Cadernos do Cárcere. Segundo Bianchi (2008) notas de conteúdo muito denso, porém "provisórias, inacabadas" (p. 21).

O ponto principal da obra de Gramsci que vamos abordar é o conceito de ideologia, mas para compreendermos tal significado, se faz necessário falarmos sobre os demais pontos da teoria gramsciana (Capítulos 2.3). Em linhas gerais, o teórico italiano aborda a questão da ideologia sob três formas complementares conforme elucidado por Portelli (1977):

(i) como ideologia da classe dirigente, abrangendo todos os ramos da ideologia, em áreas como artes, ciências, economia, direito, etc;

(ii) como concepção de mundo, que é difundida de maneira ampla nas mais diversas camadas sociais para liga-las às classes dirigentes: assim ela se impregna e se adapta a todos os grupos e

(iii) como se trata da direção de cunho ideológico da sociedade, se exprime sob três faces: (a) com as organizações que criam e difundem a estrutura ideológica e (b) com os instrumentos de difusão ideológicos, ou seja, o material ideológico, como o sistema escolar, a mídia de massa, as bibliotecas (p. 22)

A utilização de Gramsci nesse estudo se dá por dois motivos. O primeiro, devido à identidade ideológica do autor dessa tese com o pensamento gramscista. Em segundo 
lugar, como buscamos efetuar o estudo da disseminação da ideologia dominante no Brasil através de uma visão material, as ideias de Gramsci mostram-se adequadas no que se refere a hegemonia e disseminação ideológica.

Para isso estudaremos uma fase de muitas mudanças no Brasil: o Império durante os anos de 1853 (segunda "fundação" do BB) e 1902, passando pela época da República da Espada (1889-1894) e os dois primeiros presidentes da República Oligárquica (1894 - 1902), através de dados contidos nos relatórios anuais, demonstrações contábeis (e seus conceitos), pareceres de conselho fiscal, relatórios da presidência e da gerência (o que chamaremos de financial reporting, conceito mais amplo que apenas demonstrações financeiras), além de correspondências trocadas entre o banco e o poder político. Para fins de análise, dividimos em duas grandes frentes: (a) questões de discurso e (b) questões conceituais contábeis específicas.

Como argumento, nossa tese defende que as demonstrações contábeis e demais formas de comunicação com o público são instrumentos de disseminação e controle ideológico, mas ao conterem essas características, evidenciam também as contradições do sistema capitalista-burguês.

As nossas conclusões mostram que o Banco do Brasil ao longo do período áureo da produção cafeeira nacional foi utilizado pelo poder dominante, apoderado do Estado, para a transferência de recursos para a burguesia, contribuindo de maneira importante para a desigualdade econômica e social em nosso país.

Nesse sentido, verificamos que apesar das diversas mudanças de cunho político, com Império, República Militar e República da Oligarquia, a ideologia dominante permanece a mesma, privando os demais brasileiros da sua noção consciente de sua existência em plenitude.

Mais precisamente observamos nesse interim, em primeiro lugar, a interface entre sociedade civil e sociedade política no seio do Estado Brasileiro durante o período estudado.

Em segundo lugar, percebemos o vínculo orgânico entre a estrutura e a superestrutura no Brasil e os efeitos para os beneficiados.

Nesses dois pontos falaremos sobre a questão dos conflitos entre intelectuais orgânicos e os tradicionais e as ações da classe dominante para manter a ideologia do mesmo grupo. Adicionalmente, a tentativa de transformismo do intelectual rural e de 
algumas classes subalternas e por fim, o abandono das regiões e classes desfavorecidas.

Não cumpriu, pois, sua secular missão.

A fim de melhor compreensão, nossa pesquisa está estruturada em 5 capítulos:

CAPÍTULO 1 - INTRODUÇÃO: após a contextualização geral do trabalho acima, elucidamos alguns aspectos geralmente negligenciados pelos pesquisadores da área contábil: epistemologia e ontologia (Parte 1.1); a seguir, são levantadas algumas críticas ao paradigma atual da pesquisa em nosso campo: o positivismo, bem como discutiremos alternativas, como o interpretativismo e sobretudo, a teoria crítica (Parte 1.2); na sequência desse trabalho, são comentados o objeto, o objetivo e o método utilizado no mesmo (Parte 1.3).

CAPÍTULO 2 - REFERENCIAL TEÓRICO: na sequencia a essa seção de apresentação das bases do trabalho (Capítulo 1), comentamos a plataforma teórica utilizada no trabalho, focando aspectos importantes do Brasil do século XIX e início do XX: respectivamente, a sociedade brasileira e as mudanças na sociedade e economia brasileira no período (Parte 2.1), uma seção sobre um pequeno histórico do Banco do Brasil (Parte 2.2), bem como a elucidação dos principais conceitos da obra do marxista italiano Antonio Gramsci aplicadas nesse estudo (Parte 2.3).

\section{CAPÍTULO 3 - FINANCIAL REPORTING COMO INSTRUMENTO DE DISSEMINAÇÃO IDEOLÓGICA: ELEMENTOS DO DISCURSO: contém as} análises de discurso com base no arcabouço gramsciano do financial reporting do Banco do Brasil entre 1853 e 1902, em primeiro lugar (3.1), nos seguintes aspectos: (3.1a) o café como símbolo do bem público; (3.1b) abandono das regiões desfavorecidas do país; (3.1c) o discurso elitista no tocante aos diferentes tipos de funcionários e (3.1d) a questão dos escravos e da abolição desse sistema. Nesse certame, também verificaremos a cooptação do intelectual rural (transformismo) com a política benévola do banco e do governo para com os pequenos e médios proprietários, sobretudos, os cafeicultores. Em segundo lugar (3.2), vamos abordar a interação entre a sociedade civil e sociedade política brasileiras no seio do Estado brasileiro mais especificamente no tocante às (3.2a) ao interesse final da instituição, em especial em relação às operações efetuadas entre o Banco do Brasil e o Poder Político, (3.2b) a questão das revoltas populares, destacadamente aquelas ocorridas 
nos anos primeiros da república e por fim estudaremos a (3.2c) transição do poder político brasileiro, desembocada com a Proclamação da República aos 15 de Novembro de 1889 e posteriormente, em 1894, com a queda do gabinete militar para o civil oligárquico, em que são verificados os conflitos entre os intelectuais tradicionais e os orgânicos, bem como o alguns elementos que podem (ou não) indicar o reajustamento do bloco histórico nacional.

CAPÍTULO 4 - FINANCIAL REPORTING COMO INSTRUMENTO DE DISSEMINAÇÃO IDEOLÓGICA: ELEMENTOS CONCEITUAIS CONTÁBEIS: vai evidenciar assuntos conceituais específicos, como o cálculo do lucro, a questão dos títulos duvidosos e a nefasta distribuição de dividendos. Nesse sentido, como a regulamentação contábil à época era praticamente inexistente os intelectuais tinham liberdade para deturpar alguns conceitos contábeis, com algumas omissões importantes, como a não-consideração como despesa os títulos duvidosos ou aqueles já considerados prejuízos. A própria bonificação dos diretores, representantes da burguesia nacional não transitava pelo resultado. Assim, o cálculo do lucro era seriamente comprometido. Nesse certame, o Banco do Brasil como veremos mais a frente tinha como praxe a distribuição quase completa de seu lucro a título de dividendos para as classes abastadas da corte e para o Estado, principalmente. Como sabemos que lucro não significa necessariamente caixa, durante o período a classe dominante transferiu recursos para sua ganância, descapitalizando a instituição de maneira importante, com efeitos inclusive sobre aquelas classes mais baixas, que não tinham acesso aos capitais fornecidos a título de empréstimo pelo banco, bem como contribuindo para o incremento do abismo social entre os mais ricos e os mais pobres no país.

CAPÍTULO 5: CONSIDERAÇÕES FINAIS E CONCLUSÕES: Por fim, fazemos as considerações finais bem como as conclusões do trabalho e encerramos, finalmente, com as referências utilizadas no nosso estudo. 


\section{2 - CONTEXTUALIZAÇÃO EPISTEMOLÓGICA E ONTOLÓGICA}

(...) lá fora, mesmo através da vidraça fechada, o mundo parecia frio. Na rua, pequenos rodamoinhos de vento levantavam em pequenas aspirais poeira e papéis rasgados, e embora o sol brilhasse e o céu fosse dum azul berrante, parecia não haver cor em coisa alguma, salvo nos cartazes pregados em toda parte. $\mathrm{O}$ bigodudo olhava de cada canto. Havia um cartaz na casa defronte, $\mathrm{O}$ GRANDE IRMÃO ZELA POR TI, dizia o letreiro, e os olhos escuros procuravam os de Winston. Ao nível da rua outro cartaz, rasgado num canto, trapejava ao vento, ora cobrindo ora descobrindo a palavra INGSOC. Na distância um helicóptero desceu beirando os telhados, pairou uns momentos como uma varejeira e depois se afastou num vôo em curva. Era a Patrulha da Polícia, espiando pelas janelas do povo. Mas as patrulhas não tinham importância. Só importava a Polícia do Pensamento (Orwell, 1948/2009, p. 1).

Começo essa investigação com um pequeno trecho do livro clássico 1984, de George Orwell. Obra que foi finalizada em 1948 e sua denominação é famosa por ter os dígitos invertidos em relação ao seu ano da conclusão, com o intuito de mostrar que aquela realidade abordada no livro não era uma ameaça (tão) distante.

A realidade descrita em Oceânia, ex-Londres, gira em torno da história de Winston e sua luta em torno de um ambiente controlado física e mentalmente pelo Grande Irmão. Uma história de totalitarismo e dominação. Uma criação e destruição da realidade segundo os desejos do Partido, do poder dominante. O grande poder era a habilidade de controlar e contar os fatos segundo esses interesses, alienando as pessoas de sua mais íntima e individual existência.

Essa pesquisa vai em contraponto ao discutido por Orwell a fim de questionar a realidade em que a contabilidade é desempenhada. Morgan (1988) aponta que "os contadores geralmente vêem a si mesmos como avaliadores objetivos da realidade, representando (a realidade) 'como ela é' (...) os contadores tipicamente constroem a realidade de uma maneira limitada e única"” (p. 477), ideia essa corroborada por Hines (1988).

\footnotetext{
${ }^{1}$ Accountants often see themselves as objective appraisers of reality, representing reality "as it is" (...) accountants typically construct reality in limited and one-sided ways.
} 
Mais precisamente no tocante as questões mais amplas na definição do conhecimento, Chua (1986b) afirma que dado que a interação mútua entre o conhecimento e os homens, o mundo físico e a criação do conhecimento são circunscritos em "regras de crenças" (p. 583) que definem os domínios do conhecimento (a), o fenômeno empírico (b) e a relação entre estes (c): coletivamente, esses 3 conjuntos de crenças delineiam a forma como se enxerga e como se pesquisa o mundo a nossa volta. A discussão na filosofia e demais áreas sociais é muito ampla e descreveremos brevemente esses pontos, devido a amplitude do tema:

O primeiro (a) tem a ver com o que uma pessoa ou um grupo delas entendem como conhecimento, dividido em premissas epistemológicas (a1) e metodológicas (a2): as premissas epistemológicas decidem o que é uma "verdade aceitável" dentro de critérios específicos e as metodológicas, as maneiras (válidas) em se alcançar essa "verdade".

O segundo (b) corresponde às premissas sobre o objeto de estudo, a ontologia (b1), intenção humana e racionalidade (b2) e conceitos de ordem e/ou conflito social (b3). A ontologia (b1) é o ponto inicial de qualquer geração de conhecimento, mesmo antes da epistemologia e metodologia já que primordialmente se deve verificar qual a atitude do pesquisador diante do objeto de seu estudo: ele de fato existe? Há uma série de premissas ontológicas, destacando-se na pesquisa contábil o realismo (os objetos existem independentemente do pesquisador) e subjetivismo (os objetos não existem, são atribuídos significados subjetivos aos mesmos). A intenção humana e racionalidade (b2) são fundamentais já que todo o conhecimento é intencional a um propósito e constituído por desejos humanos e seus objetivos. O terceiro e último ponto (b3) é ligado as ideias sobre a natureza da sociedade humana, se é conflituosa ou essencialmente estável e ordenável.

A terceira premissa (c) busca aludir qual o papel do conhecimento para o "mundo prático": se para melhorar o bem-estar dos indivíduos, para emancipar as pessoas da repressão ou para respostas técnicas para objetivos pré-determinados.

Entender como qualquer autor se posiciona em relação a esses pontos é primordial, já que todo o desenrolar de seu trabalho deriva destes. Embora na academia contábil exista uma linha mainstream, fontes alternativas podem oferecer explicações e teorias 
que complementam ou contrariam esta, causando assim um crescimento tanto em quantidade quanto em qualidade dos debates nos meios acadêmicos e profissionais.

O Quadro 1 sumariza a classificação das premissas, ou como aponta Chua (1986b), da matriz disciplinar:

Quadro 1 - A Matriz Disciplinar de Chua

\section{A. Crenças sobre o conhecimento}

Epistemológico

Metodológico

B. Crenças sobre a realidade física e social

Ontológico

Intenção humana e racionalidade

Ordem social/Conflito

\section{Relações entre teoria e prática}

Conclusão da seção:

Em nossa pesquisa, adotaremos quanto ao primeiro ponto (a) a visão da Construção Social (Social Construction) e ao segundo (b) a perspectiva do Realismo (Realism). Contrariamente ao Objetivimo inerente ao Positivismo (como abordaremos mais a frente), a Construção Social e o Realismo pressupõem que os objetos existem, porém esses não tem significado até que determinado por alguém ou por algum grupo; assim não há verdade contida nos mesmos, como subjacente à pesquisa mainstream em contabilidade no cenário atual. Ao contrario, a realidade é contingente à prática dos seres humanos. (Crotty, 1998). Em relação ao ponto (c), consequentemente, a visão de que o conhecimento deve ser gerado (principalmente nas "ciências" tidas como sociais ou humanas) para libertar os homens de cenários e condições repressivas, o que impede seu entendimento de ser enquanto ser. 
Ou seja, não temos aqui inteção de predizer, função primeira da pesquisa positivista, mas sim de fornecer uma explicação da realidade baseada em um ambiente de conflito de classes. 


\section{3 - CRÍTICAS AO PARADIGMA ATUAL E O PORQUÊ DAS PREMISSAS ONTOLÓGICAS E EPISTEMOLÓGICAS ADOTADAS NESSA PESQUISA}

O papel da teoria da contabilidade é fornecer explicação e predição para as práticas contábeis. (Watts \& Zimmermann, 1990, p. 148)

Com essa frase positivista de Watts \& Zimmermann inicio a seção 1.3 do trabalho, que essencialmente visa conceituar, questionar e oferecer alternativas no modo em que os cientistas da contabilidade (do nosso país essencialmente, mas que se estende à muitos outros também) entendem como ciência.

A pesquisa contábil no Brasil ainda carece de outras abordagens epistemológicas e ontológicas. E nesse contexto esse trabalho pretenderá se inserir.

Chua (1986) bem pontua que:

A pesquisa mainstream em contabilidade é fundada em um conjunto comum de premissas filosóficas sobre conhecimento, o mundo empírico, e a relação entre teoria e prática. Esse modelo particular de ver o mundo, com ênfase no modelo hipotético dedutivo e controle técnico, possui certos pontos fortes, mas restringiu a amplitude de problemas estudados e o uso de métodos de pesquisas. Mudando esse conjunto de premissas, obteremos uma pesquisa diferente e potencialmente mais rica ${ }^{2}$. (p. 601)

A autora bem como muitos outros antes e depois (Hines, 1986, 1987, 1988; Morgan, 1988; Tinker, 1988; Covaleski \& Dirsmith, 1990; Laughlin, 1995; Baker \& Bettner, 1997; Merino, 1998; Parker, 2007; Arnold, 2012; Aversari Martins, 2012 - no Brasil)

\footnotetext{
${ }^{2}$ Mainstream accounting is grounded in a common set of philosophical assumptions about knowledge, the empirical world, and the relation between theory and practice. This particular world-view, with its emphasis on hypothetic-deductivism and technical control, possesses certain strengths but has restricted the range of problems studied and the use of research methods. By changing this set of assumptions, fundamentally different and potentially rich research are obtained.
} 
questionam de maneira muitas vezes ácida o jeito em que o mundo acadêmico vem criando o conhecimento contábil.

Baseada na matriz do conhecimento, Chua (1986a) explica a maneira dominante de pesquisa (positivismo), além de duas fontes alternativas: o interpretativismo e a teoria crítica. Falaremos brevemente sobre esses pontos, bem como as críticas ao modo mainstream de se desempenhar pesquisas na área contábil:

Quando Chua analisa o positivismo, a respeito do ponto (b) crenças sobre a realidade física e a realidade social, ela diz que esse modo de se pesquisar se afirma na crença do realismo físico: nesse sentido, é fundamental a conhecida distinção e afastamento do objeto e do sujeito, já que um é independente do outro. A maioria das pesquisas mainstream entendem que o retorno no mercado de ações é um fato objetivo que pode ser classificado como normal ou anormal.

No tocante ao item (a) crenças sobre o conhecimento existe uma realidade física que o pesquisador precisa descobrir, utilizando o método erroneamente chamado de "científico" (como se as outras maneiras não o fossem), baseados na empiria, observação e métodos quantitativos, tentando (em vão) se aproximar das hard sciences, como física e matemática. Assim ficam testando as teorias criadas nessa repetição monocromática de retorno de ações, já que o conhecimento deve permitir explicar e predizer a realidade, como as Leis de Newton.

Como a autora coloca (Chua, 1986a) há uma aceitação quase universal entre nós do argumento hipotético-dedutívo de Hempel (1905 - 1997), filósofo, físico e matemático alemão, que considera que para ser científico uma explicação deve ter 3 componentes: (i) deve incorporar uma ou mais princípios e leis gerais; (ii) deve existir uma hipótese, uma observação inicial e (iii) deve haver uma descrição do que está sendo explicado (p. 607). Logo há uma busca constante e interminável de relações mais generalizáveis possíveis: os pesquisadores aparentam acreditar que o mundo empírico não é apenas objetivo, mas principalmente caracterizado como uma série de relações constantes que são passíveis de serem descobertas. Em consequência, essas crenças sobre a explicação científica influenciaram de sobremaneira a escolha dos métodos "válidos" para solucionar os problemas do mundo empírico: insere-se uma hipótese, coletam-se os dados e obtem-se uma conclusão baseada nos dados observados, afirmando ou negando a hipótese pré-estabelecida. Quando se fala das 
crenças sobre o mundo social, as duas premissas mais importantes da pesquisa mainstream são: (i) o comportamento humano é proposital: as pessoas tem objetivos que desejam alcançar, sendo o principal a maximização da utilidade e (ii) há um princípio de ordem social controlável: embora existam conflitos entre agentes, esses são possíveis de ser gerenciados, remediados. Mas são sempre considerados "disfuncionais" na teoria. Como exemplo, temos a crença da maioria dos pesquisadores de que as organizações e os mercados tem uma tendência natural à ordem social.

Já o ponto (c) relações entre teoria e prática, os pesquisadores contábeis devem apenar verificar quais as maneiras mais eficazes e eficientes de atender as necessidades informacionais, sem efetuar qualquer julgamento (subjetivo) sobre as necessidades daqueles. A conhecida ciência livre de valor ou de viés.

O quadro 2 destaca os principais pontos da pesquisa mainstream em contabilidade:

Quadro 2 - As premissas da pesquisa mainstream em contabilidade

\section{A. Crenças sobre o conhecimento}

A teoria é segregada da observação que é utilizada para verificar ou falsear uma teoria. Explanação científica baseada nos ditames hipotéticos-dedutivos

Preferência por métodos quantitativos de análise e coleta que favoreçam a generalização

\section{B. Crenças sobre a realidade física e social}

A realidade empírica é objetiva e externa ao sujeito. Seres humanos são objetos passivos.

Objetivo único de maximização da utilidade para indivíduos e empresas. Racionalidade assumida.

Sociedades e organizações são essencialmente estáveis: conflitos disfuncionais podem surgir e ser gerenciados

\section{Relações entre teoria e prática}

Contabilidade significa "meio", não "fim".

Após a descrição da matriz disciplinar, a autora aponta uma série de críticas, elucidando as consequências e limitações da pesquisa mainstream. Listamos abaixo as principais: 
Em primeiro lugar, a visão de que a estrutura social, política e econômica são préestabelecidas e naturais: questionar esses aspectos está fora de escopo da pesquisa mainstream. Aceitamos, não questionamos. Assim, criamos e reforçamos uma realidade que nós é dada, imposta. Ela critica essa premissa, já que como aponta Weber a distinção entre fato e valor já é por si só um julgamento. Isso favorece o status quo.

Em segundo lugar, a premissa da racionalidade e propósitos humanos: baseados nos conceitos da microeconomia, o pensamento da pesquisa mainstream é estruturado segundo os interesses dos proprietários ou acionistas, que devem ser satisfeitos: se esse objetivo for atingido, todos os outros também serão. Será realmente esse pensamento simplista que explica o sucesso de uma organização? E dentro dessa racionalidade são criados conceitos objetivos que vão reforçando tanto as coisas quanto às ideias que se têm das coisas.

Em terceiro lugar, a contabilidade não acompanhou o debate filosófico das ciências sociais sobre realismo e teste de teorias, já que as observações que suportam as conclusões também são falíveis e não neutras: quase caminhando para um absoluto relativismo da verdade e escolha quase irracionais de teorias. A pesquisa mainstream ignorou e ignora novos questionamentos surgidos em outras áreas, esses de natureza filosófica. O resultado disso é na visão de Baker \& Bettner (1997) uma "homogeneidade de outputs de pesquisa que não refletem a realidade social complexa na qual a contabilidade opera." (p. 301).

A pesquisa em contabilidade financeira é efetuada como se o mainstream fosse a única maneira de se fazer ciência, segundo Hines (1987). Isso obscurece os papéis da mesma na criação e manutenção da sociedade. Como bem pontua Hines (1988) em outro famoso paper: “em comunicar a realidade, nós construímos a realidade.” (p. 251).

E como superar? Há modos alternativos?

A primeira alternativa à pesquisa positivista é a abordagem interpretativista. Segundo a Chua (1986a) essa linha enfatiza os papéis da linguagem, interpretação e compreensão nas mais diversas ciências e técnicas sociais. No que tange às crenças sobre o conhecimento (a), a linha interpretativista busca compreender as ações humanas inserindo-as em uma lista de objetivos individuais e também na estrutura 
social de significados. No tocante às crenças sobre as realidades física e social (b), a noção de consciência humana surge apenas quando os seres detém sua atenção e atribuem significado às coisas. As ciências sociais se preocupam, então, em entender como as pessoas atribuem significado aos mais diversos elementos e construções. Ganha importância como um grupo de pessoas criam e relacionam esse conceito: a interação social contínua torna esses significados objetivamente reais de maneira intersubjetiva. Conforme Chua (1986a) "eles formam uma compreensível e dada realidade social que confronta o indivíduo de maneira análoga ao mundo natural." 3 (p. 614). Já o mundo social é baseado em duas premissas principais: (i) a atribuição de propósitos as ações humanas e (ii) um mundo pré-estabelecido e ordenado de significados que estruturam a ação. Já em relação a teoria e prática (c) o conhecimento gerado por essa linha mostra como e o que as pessoas estão fazendo quando essas agem e falam da maneira que elas o fazem: a busca por estruturas simbólicas é mister. O principal objetivo é fornecer as pessoas mais elementos à compreensão das suas ações. O Quadro 3 pontua as premissas de Chua na linha:

Quadro 3 - As premissas da pesquisa interpretativista em contabilidade

\section{A. Crenças sobre o conhecimento}

A explicação científica da intenção humana, avaliada pela consistência lógica, interpretação subjetiva e concordância com a interpretação comum dos atores.

Trabalhos etnográficos, estudos de caso e observação-participante. Os atores são estudados no seu mundo cotidiano.

\section{B. Crenças sobre a realidade física e social}

A realidade social é emergente, criada subjetivamente e objetivada através da interação humana.

Todas as ações tem significados e intenções que são dotadas e baseadas nas práticas sociais e históricas.

Ordem social assumida. O conflito é mediado através de esquemas de significados sociais.

\section{Relações entre teoria e prática}

A teoria visa apenas explicar a ação e entender como a ordem social é produzida e reproduzida.

\footnotetext{
${ }^{3}$ They form a comprehensive and given social reality which confronts the individual in a manner analogous to the natural world.
} 
Por fim, a alternativa crítica quanto a matriz do conhecimento contábil de Chua tem em relação ao item (b) crenças sobre a realidade física e social de que no seu estado mais puro de existência, um individuo ou sociedade tem potencialidades historicamente constituídas que não são satisfeitas. A famosa frase: "tudo é devido ao que é e ao que não é ${ }^{4}$." Porém essas potencialidades humanas são restringidas pelos sistemas de dominação prevalecentes em um dado momento histórico, operando tanto no nível da consciência quanto nas condições materiais, econômicas e políticas. Chua aponta (1986a) que as construções ideológicas podem estar embutidas no nosso modo de conceitualização, na nossa maneira de criar o senso-comum e dado como naturais sobre práticas sociais aceitáveis (p. 619). Assim, a sociedade está presente apenas na ação humana, que lhe atribui significado: a realidade social é ao mesmo tempo subjetivamente criada e objetivamente real. Importante para nossa pesquisa é a afirmação (Chua, 1986a) de que "existe uma ênfase no estudo do desenvolvimento histórico das entidades", já que para entender uma parte particular temos que entender o estágio anterior de existência. (p. 620).

Em relação às crenças sobre o conhecimento (a) a "verdade é muito mais o processo de ser forjado e é galgado nas práticas social e história. Não há fatos teoriaindependentes que podem conclusivamente provar ou rejeitar uma teoria." ${ }^{5}$ (p. 620). A ênfase em estudos históricos de longo prazo é encorajada, dada a premissa de que um fato ou objeto só pode ser "entendido" através de uma análise histórica: o que ele foi, o que está se tornando e o que ele não é. Quanto ao entendimento do mundo social, há uma similaridade com o interpretativismo, já que é fundamental a linguagem do objeto/sujeito. Porém essa interpretação está longe de ser simbolicamente mediada, mas moldada pelas condições materiais de opressão. A teoria crítica em consequência foca as relações de poder e conflito social, pretendendo, enfim, responder questionamentos dos seguintes tipos: como os sujeitos constroem seus mundos? Qual o papel do poder e da política? Por que somos e por que não somos? Por que as coisas são do jeito que são? Nesse cenário, diferentemente do paradigma positivo, a alternativa crítica é fortemente histórica, sendo que a essa leva ao hoje, dado que as ideias se mantem ao longo dos períodos. Essa linha toma uma série de posições intelectuais que examinam os arranjos sociais através das lentes

\footnotetext{
${ }^{4}$ Everything is because of what it is and what it is not.

5 Truth is very much in the process of being hammered out and is grounded in social and historical practices. There are no theory-independent facts that can conclusively prove or disprove a theory.
} 
do poder, dominação e conflito, com o compromisso de examinar e questionar as premissas mais básicas das práticas sociais, a fim de mudar o sistema. Quando aplicado a ciência, está muito mais ligada com a ampla tradição da intelligentsia, no qual o processo de pesquisa é visto muito mais como um compromisso à crítica e a dialética do que à mera praxis ou método, como na pesquisa mainstream da área contábil (Alvesson \& Deetz, 2000).

Quando se fala da relação entre teoria e prática (c), Chua (1986a) afirma que a teoria está preocupada com a liberdade do espírito humano, que tem a função de trazer ao conhecimento as condições restritivas a que somos impostos em nossa experiência mundana. Como ela bem pontua (Chua, 1986a): "isso envolve demonstrar que as chamadas leis sociais universais e objetivas são apenas produtos de formas particulares de dominação e ideologia.” (p. 621). A posição moral do pesquisador é de que essas formas de injustiças devem ser expostas e muito mais do que isso, mudadas. Ou como afirmam Arrington \& Watkins (2002) a tradição crítica tanto quando expõe nossas racionalidades contemporâneas inquestionadas ou quando tenta nos livrar das mais diversas formas de opressão busca, em última instância, nossa emancipação. (p. 141). O Quadro 4 contempla a matriz do conhecimento na alternativa crítica: 
Quadro 4 - As premissas da pesquisa crítica em contabilidade

\section{A. Crenças sobre o conhecimento}

Os critérios para julgamento de teorias são temporais e contextualizadas.

Pesquisas históricas, etnográficas e estudos de caso são as metodologias mais comuns

\section{B. Crenças sobre a realidade física e social}

Os seres humanos tem potencialidades internas que são alienadas através de mecanismos restritivos. Os objetos apenas podem ser estudados através de seu desenvolvimento histórico e mudança dentro do contexto da totalidade das relações.

A realidade empírica é objetiva com relações reais que são transformadas e reproduzidas por interpretações subjetivas.

Intenção humana e racionalidade são aceitas, mas são criticamente analisadas sob a premissa de falsa consciência e ideologia.

O conflito é endêmico à sociedade. Esse surge devido a injustiça e ideologia nos domínios sociais, econômicos e políticos o que impele a dimensão criativa dos seres humanos.

\section{Relações entre teoria e prática}

O imperativo é: a identificação e remoção de práticas de dominação e ideológicas.

\section{Conclusão da seção:}

Parece que nos esquecemos (a academia principalmente) que a contabilidade é acima de tudo uma prática humana, baseada na interação entre indivíduos e organizações, que segundo Carnegie e Napier (2012), são seres capazes de aprender com o tempo, sendo que suas ações e pensamentos são em grande medida produto de seu passado, bem como da sociedade, mas primordialmente ideologicamente constituído e tido como verdade absoluta e universal. Os mesmos apontam que "as nossas atividades presentes, quando vistas sob a lente da história, nem parecem eternas nem efêmeras, mas são fundamentadas em seu passado ${ }^{6} . "($ p. 330).

\section{Assim sendo, não buscamos em nossa tese encontrar a verdade, mas contar uma verdade (grifo nosso).}

\footnotetext{
6 Our current activities, when viewed through the lens of history, appear neither eternal nor ephemeral, but are grounded in their past.
} 
Crook (2008) bem afirma que:

(...) Eu sei que não encontrei a verdade completa; eu acharia apenas fragmentos como peças de quebra-cabeças. Eu pegaria essas peças e formaria uma figura, sempre sabendo que haveria peças importantes escondidas de mim. Talvez alguém pegue minha figura e adicione as peças perdidas e mude a figura de tal maneira que todos nós contribuímos para o seu entendimento. Meu trabalho seria então importante, mas não como uma figura final da situação (...). ${ }^{7}$ (p. 14)

Ansiamos, pois, debater a contabilidade e demonstrar a relevância no seu estudo em aspectos mais amplos, como sociedade e conflitos. Não menos importante que o apontado anteriormente, também que este trabalho seja um incentivo às formas ditas alternativas de se fazer pesquisa, sobretudo no ambiente científico contábil brasileiro.

7 (...) I knew that I would not find a whole truth; I would find bits like puzzle pieces. I would take those pieces and form a picture, all the while knowing that there were important pieces hidden from me. Perhaps someone else will take my picture and add the hidden pieces and change the picture so that we all contribute to understanding. My work would then be important, but not necessarily a stand-alone picture of the situation (...) 


\section{4 - OBJETIVOS, OBJETO E MÉTODO DE ANÁLISE}

No início do livro clássico de 1979 , intitulado Accounting Theory, Kenneth Most (1979) afirma que não há uma definição satisfatória da palavra "contabilidade": aquela mais amplamente difundida é proveniente do American Institute of Certified Public Accountants (AICPA), em seu Boletim n.1 de 1941:

Contabilidade é a arte de registrar, classificar e sumarizar de maneira significativa e em termos monetários, transações e eventos que são, em parte pelo menos, de caráter financeiro e então, interpretar os resultados obtidos. ${ }^{8}$ (p. 1).

Já na década de 1970, Most (1979) afirma que o Accounting Principles Board (APB) em seu pronunciamento n. 4 (Statement n.4) efetua sua definição de contabilidade fazendo referência ao conceito de "informação para um usuário na tomada de decisão econômica":

Contabilidade é uma atividade de serviço. Sua função é prover informação quantitativa, primariamente financeira em sua natureza, sobre entidades econômicas e que tendam a ser úteis na tomada de decisões econômicas, em decisões racionais entre diferentes alternativas de ação. ${ }^{9}$ (p.4).

Cabe lembrar que essa ainda é a postura dos órgãos normatizadores internacionais, International Accounting Standards Board (IASB) e Financial Accounting Standards Board (FASB). A Estrutura Conceitual para Elaboração e Divulgação de Relatório Financeiro (Framework) do primeiro aponta que o objetivo primeiro das demonstrações contábeis é fornecer informação útil a investidores atuais e potenciais, bem como aos credores, quando da tomada de decisão econômica. O próprio Board afirma que diferentemente do senso comum, as demonstrações financeiras não são

\footnotetext{
${ }^{8}$ Accounting is the art of recording, classifying, and summarizing in a significant manner and in terms of money, transactions and events which are, in part at least, of a financial character, and interpreting the result thereof.

${ }^{9}$ Accounting is a service activity. Its function is to provide quantitative information, primarily financial in nature, about economic entities that is intended to be useful in making economic decisions, in making reasoned choices among alternative courses of action.
} 
elaborados para se alcançar o valor da empresa, mas para auxiliar os diversos stakeholders a calcularem essa informação. Nesse sentido, para alcançar esse objetivo as informações contábeis devem conter uma série de características qualitativas, tais como relevância/materialidade e representação fidedigna (características fundamentais) e comparabilidade, verificabilidade, tempestividade e compreensibilidade (características de melhoria). (IASB, 2016).

Assim sendo, a contabilidade e as demonstrações financeiras são tidas como as principais fontes de informação para os usuários externos sobre a "realidade econômica" de uma entidade. Cabe destacar que os diversos demonstrativos contábeis são preparados segundo as regras contábeis e que estas, por sua própria natureza, deixam de captar alguns eventos, como por exemplo as marcas (quando não adquiridas em combinações de negócios), pessoal qualificado, etc.

Há um sentimento enraizado na cultura corporativa de que essa contabilidade representa a "verdade" sobre uma organização, ou como apontam os pareceres dos auditores independentes, "uma visão justa e verdadeira" acerca da condição financeira da empresa. (Hines, 1991; Clarke, Dean \& Oliver, 2003; Lee, 2006; Macintosh, 2006).

Mas essa é uma visão deturpada e limitada, já que embora muitos entendam a contabilidade como "exata", no momento em que os débitos são iguais aos créditos, o ativo igual ao passivo adicionado ao patrimônio líquido, todos aqueles números, fechando como magia, conferiram à nossa disciplina uma aura imaculada e sacra. E o mundo inteiro utiliza os números provenientes dos demonstrativos para os mais diversos fins, sem se questionar quem fez, por que fez, como fez. As pessoas acreditam nos contadores e no produto de seu trabalho, já que conforme aponta Most (1979) “(...) o contador tem outra função pública no qual ele ou ela é identificado(a) como uma pessoa de confiança, um(a) profissional que a sociedade pode dar uma variedade de tarefas sabendo que eles(as) vão executar segundo o interesse público." ${ }^{10}$ ( p.3).

Porém, a dinâmica e o contexto em que a contabilidade é desempenhada são muito mais complexos que isso. A nossa disciplina, sendo uma técnica social é feita por

\footnotetext{
${ }^{10}$ (...) the accountant has another public role in which he or she is identified as a person of trust, a professional whom society can give a variety of tasks knowing they will be performed in the public interest.
} 
humanos e para humanos a fim de atingir um objetivo. Essa realidade ou verdade apontada nos parágrafos anteriores é apenas uma utopia, já que os números e relatórios provenientes da contabilidade são influenciados de sobremaneira pelas pessoas e seus contextos que os preparam. Quem são essas pessoas? A resposta pode parecer óbvia: os contadores. Mas isso não é verdade por completo, já que estes indivíduos são contratados pela entidade (capitalistas) para desempenhar sua função e toda as camadas de intelectuais, inclusive em seu próprio campo profissional. A contabilidade, então, é influenciada de maneira importante pelo poder dominante, tanto no nível material quanto no ideológico, quando da confecção desses demonstrativos. Além disso, em uma visão marxiana, as construções ideológicas criadas pelo modo de vida e de produção capitalista do nosso mundo ao transformar todas as esferas da vida cotidiana e do raciocínio, tornam, inclusive, a contabilidade e seus relatórios instrumentos de criação de fatos e realidades consumadas que alienam as pessoas, impelindo-as de entender a situação de completa dominação a que são sujeitas (inclusão nossa).

O objetivo principal dessa pesquisa é evidenciar como o poder dominante se utiliza do financial reporting para fins ideológicos (como instrumento de disseminação) e, consequentemente de controle hegemônico, através da criação de "uma realidade" que satisfaça seus interesses.

Nossa unidade de estudo será o Banco do Brasil no período compreendido entre 1853 e 1902, período em que o nosso país era visto com uma imensa plantação de café. Essa fase é muito importante na história do Brasil, já que, conforme apontado pela nossa historiografia econômica clássica, como Celso Furtado (1958/2007) e Caio Prado Jr. (1945/2012) o capital oriundo do café foi determinante para o desenvolvimento econômico e social no país. E como veremos todos os esforços da nação foram empenhados nesse gênero agrícola.

Mais especificamente analisaremos as demonstrações contábeis e demais formas de comunicação com o mercado, tais como as relatórios anuais, pareceres de conselho fiscal, relatórios da presidência e da gerência, etc (o que chamamos de financial reporting), que ao contarem a realidade segundo os interesses capitalistas, também mostram suas contradições. 
Nessa direção, Chua (1986a) aborda algumas características importantes da teoria crítica quando inseridas no ambiente de pesquisas contábeis e que essa tese corrobora incondicionalmente. A primeira é de que a contabilidade não é mais vista como uma técnica racional, uma ferramenta que é separada das relações sociais mais amplas: a contabilidade deve ser encarada como um modo de acentuar e constituir conflitos tanto em nível micro (empregados x gerentes, acionistas x administração) quanto no nível macro (proletariado x classe dominante, empresas x Estado). A segunda é o interesse nos fenômenos estruturais mais amplos que são negligenciados na pesquisa mainstream. Por fim, os contadores não são vistos mais como elementos neutros, já que estão inseridos no cenário descritos na primeira e segunda características. E o mais importante, de que a visão da informação contábil como instrumento de controle social e mediador dos conflitos são mistificados por poderosas ideologias desempenhadas no ambiente, que isolam as pessoas da sua essência verdadeira. (p. 623).

Como afirma Morgan (1988): “eles (os contadores) não são apenas técnicos desempenhando um assunto técnico. Eles são parte de um processo muito mais amplo de construção de realidade (...)” (p. 477).

A contabilidade tem a capacidade de criar e controlar a realidade: isso se traduz em poder para aqueles que a usam (Baker \& Bettner, 1997). Eles afirmam que esse poder reside nas instituições que criam valores, sustentam e legitimam mitos e fatos, mascaram conflitos e perpetuam ordem social. Quem controla a estrutura de poder tem o interesse de manter o status quo e usa a contabilidade como artifício para essa finalidade.

Nesse cenário, a utilização do Banco do Brasil como objeto de pesquisa se dá por uma série de motivos. O primeiro reside no fato que desde sua fundação é considerado um banco de função pública (controlado em essência pelo Governo, em alguns momentos, e por classes abastadas, como veremos mais a frente), sendo uma ferramenta de política econômica e social do poder estatal e das classes dominantes. Segundo, há dados disponíveis para esse longo período de tempo que estudaremos (1853-1902). Em seguida, a literatura de história econômica (Furtado, 2007, Prado Jr., 2012) aponta o período da crise do café e consequente apoio do governo, culminando na fase conhecida como Encilhamento como um dos principais entraves do desenvolvimento industrial do nosso país; e por fim, mudanças estruturais na 
economia, política e sociedade brasileira, com a abolição do trabalho escravo e a influência do café na vida do país.

Em termos amplos, pretendemos com esse estudo contribuir com o conhecimento em História da Contabilidade (em menor parte) e da sociedade e economia brasileira (em maior parte), através de seu principal banco e um dos mais antigos, o Banco do Brasil, presente em nosso país desde 1808 com a chegada da família real e da corte portuguesa fugida dos temores de um iminente ataque de Napoleão Bonaparte ao reino luso.

Como na justificativa abordada mais acima essa investigação tem como contribuições desejadas, inicialmente, fornecer uma visão da contabilidade através de um novo paradigma (construção social-realismo-teoria crítica).

Em segundo lugar, dar mais subsídios para o entendimento da história e do presente da nossa sociedade e de sua prática contábil.

Terceiramente, ser um incentivo às novas pesquisas em história da contabilidade e também uma chamada aos métodos alternativos de se fazer ciência e finalmente, colocar a contabilidade como prática social e como tal, influenciada pelas pessoas, instituições, ideologias e inserida em um ambiente de conflitos.

A unidade de estudo como apontando acima é o Banco do Brasil no período compreendido entre 1853 a 1902, fase do Segundo Império Brasileiro, da República da Espada e dois primeiros representantes civis da oligarquia cafeeira. Assim, estudaremos períodos de transição do poder político, ora representado pelo Imperador ora pelos Presidentes e Vice-Presidente.

Para alcançar os objetivos da pesquisa usarei como dados 50 anos em relatórios anuais e demonstrações financeiras (primordialmente) e outras formas de comunicação com o mercado e com o público em geral, bem como outros documentos, como correspondências, relatório de gerência, pareceres, etc. Essas fontes se localizam essencialmente no Arquivo Histórico do Banco do Brasil (RJ). Foram consultadas apenas fontes primárias.

Em relação à metodologia, essa pesquisa tem caráter histórico, estudando o discurso em uma perspectiva dupla (como veremos mais a frente) empregado nas demonstrações contábeis (notadamente nos na seção Comentários da 
Administração/Presidência) do Banco do Brasil, focando nas análises ideológicas contidas nestas.

O método de análise do discurso é baseado na discussão de ideologia/hegemonia do teórico italiano Antonio Gramsci, de veia fortemente ligada a Teoria do Materialismo Histórico de Karl Marx.

Conforme abordaremos mais a frente na análise do discurso empregado, este considera a questão ideológica sob três formas complementares conforme elucidado por Portelli (1977):

(i) como ideologia da classe dirigente, abrangendo todos os ramos da ideologia, em áreas como artes, ciências, economia, direito, etc;

(ii) como concepção de mundo, que é difundida de maneira ampla nas mais diversas camadas sociais para liga-las às classes dirigentes: assim ela se impregna e se adapta a todos os grupos e

(iii) como se trata da direção de cunho ideológico da sociedade, se exprime sob três faces: (a) com as organizações que criam e difundem a estrutura ideológica e (b) com os instrumentos de difusão ideológicos, ou seja, o material ideológico, como o sistema escolar, a mídia de massa, as bibliotecas (...) (p. 22)

Objetivamos, pois, através dos dados do Banco do Brasil, identificar elementos para, em primeiro lugar, elucidar traços ideológicos da classe dominante no Brasil durante o período analisado.

Por conseguinte, pretendemos identificar traços específicos da concepção de mundo criada pela classe dirigente e a maneira pela qual ela é difundida, a fim de ser impregnada a todos os demais grupos componentes da sociedade brasileira e, por fim, a atuação específica na criação e difusão da estrutura ideológica nacional através do instrumento de difusão importante nos dias atuais e mais ainda nos dias passados, o financial reporting, devido à extrema carência de outras formas de comunicação da empresa para com o mundo externo. Ou seja, pretendemos contar a história do Brasil pelas lentes daqueles que tem o poder de contar (e fazer) a história, a classe dirigente nacional. 
Nossa tese, pois, defende que, durante o período analisado, o Banco do Brasil foi utilizado em todos os tipos de artifícios econômicos com claras intenções de lucro e manutenção das classes dominantes, tanto na esfera da sociedade civil (em seus trâmites) como na esfera da sociedade política (e sua relação intrínseca com o Estado brasileiro).

Além disso, resultados extraordinários foram obtidos para as duas partes, em detrimento do "restante do Brasil." Aquele fim de atender o interesse público e contribuir para o desenvolvimento do país é uma afirmação (ou ilusão?) bem questionável.

A análise é apresentada em duas frentes.

A primeira vai estudar o discurso proveniente dos textos oriundos do financial reporting do Banco. Visa identificar essencialmente traços da ideologia dominante em nosso país, com base no arcabouço gramsciano do financial reporting do Banco do Brasil entre 1853 e 1902, desde sua "segunda fundação", depois com a queda do Império no país, seguida da primeira República militar finda em 1894 e encerrando com os dois primeiros presidentes civis, Prudente de Moraes (1894 - 1898) e Campos Sales (1898 - 1902), representantes da chamada República Oligárquica (Cafeeira).

Neste certame, verificaremos indícios da ideologia nacional no seio do discurso empregado e mais precisamente, o (i) vínculo orgânico entre estrutura e superestrutura; (ii) a interface entre a sociedade civil e a sociedade política no seio do Estado brasileiro e (iii) a transição do poder político.

A segunda versará sobre temas contábeis específicos oriundos do financial reporting, que nos ajudam a compreender melhor ainda a ideologia dominante (e algumas ótimas razões de agirem como tal), como o cálculo do lucro, a questão dos títulos duvidosos e a nefasta distribuição de dividendos. 


\section{CAPÍTULO 2 - REFERENCIAL TEÓRICO}

\section{1 - MUDANÇAS ECONÔMICAS E SOCIAIS NO BRASIL A PARTIR DO SÉCULO XIX}

O eixo central em torno do qual tentei organizar a história do século foi, basicamente, o triunfo e a transformação do capitalismo na forma historicamente específica de sociedade burguesa em sua versão liberal. A história começa com a dupla e decisiva irrupção da primeira revolução industrial na GrãBretanha, que estabeleceu a capacidade ilimitada do sistema produtivo, criado pelo capitalismo, em promover crescimento econômico e penetração mundial, e da revolução politica franco-americana, que estabeleceu os modelos dominantes das instituições públicas da sociedade burguesa, completadas pela emergência praticamente simultânea de seus sistemas teóricos mais característicos - e inter-relacionados: a economia política clássica e a filosofia utilitarista (...) Ela levou à conquista audaciosa do planeta pela economia capitalista, conquista essa realizada por sua classe característica, a 'burguesia', e sob a bandeira de sua expressão intelectual característica, a ideologia do liberalismo (Hobsbawn, 2005, p. 23).

O mundo do século XVIII carrega consigo grandes mudanças, sobretudo encarregadas pela Inglaterra, como a máquina de fiar de Hargreaves, a máquina a vapor de James Watt, etc. O capital era mais que necessário: a burguesia incipiente ensejava novos mercados. Porém, o capitalismo recente levava à guerra, como verificado entre as potencias Inglaterra e França. O bloqueio continental que teve a incumbência de levar a família real portuguesa e a corte ao Brasil é um exemplo dessa disputa. (Alencar, Carpi \& Ribeiro, 1994)

No século XIX, com chegada dos absolutistas lusitanos, a vida na colônia e seus costumes mudam drasticamente:

Segundo Alencar, Carpi e Ribeiro (1994), o Rio de Janeiro era a cara de toda essa modernização, com iluminação a gás e agua encanada. Os teatros, os bailes, as influencias na Corte, os favores: a cidade ia se aparelhando. Hábitos simples até então desconhecidos como o ato de comer com talheres ao invés de usar a mão. Inclusive, para os fazendeiros a vinda para as grandes cidades era como um banho de 
civilização. Mas os valores ainda são aqueles ligados à aristocracia agrária, inclusive das médias camadas autônomas, que tinham as principais reinvindicações bem semelhantes aos latifundiários. (p. 183).

São criadas uma variedade imensa de órgãos que anteriormente existiam apenas na metrópole: "para muitos, o gigantismo burocrático era uma forma de justificar a presença de tantos bicudos ou marinheiros caiados na colônia. (Alencar, Carpi \& Ribeiro, 1994). Afinal era necessário dar funções a todos os membros da Corte e seus agregados. Uma dessas instituições foi o Banco do Brasil.

Nesse mesmo período, nos primeiros anos do século XIX, as mudas de café começam a se proliferar em território nacional. E como bem destacado por Prado Jr. (2012):

Nas transformações ocorridas no Brasil no curso do séc. XIX, nenhuma terá contribuído para modificar a fisionomia do país como a verdadeira revolução que se opera na distribuição de suas atividades produtivas. Tal revolução já se pode observar em seus começos na primeira metade do século; mas é na segunda que se caracteriza propriamente e se completa (...). Dois fatos (aliás, intimamente relacionados) a constituem: um de natureza geográfica: é o deslocamento da primazia da econômica das velhas regiões agrícolas do norte para as mais recentes do Centro-Sul e partes limítrofes de Minas Gerais e São Paulo). Outro é a decadência das lavouras tradicionais do Brasil - de cana-de-açúcar, do algodão, do tabaco -, e o desenvolvimento paralelo e considerável da produção de um gênero até então de pequena importância: o café, que acabará por figurar quase isolado na balança econômica brasileira. (p.154)

O parágrafo acima de História Econômica do Brasil obra clássica de 1945, (Prado Jr., 2012) resume de maneira singular a dinâmica econômica brasileira do século XIX, mais notadamente a segunda metade:

Até o terceiro quartel do século passado, toda essa área que abrange a bacia do Paraíba e regiões adjacentes será o centro por excelência da produção cafeeira do Brasil. Geograficamente forma uma unidade: assinalei suas características naturais e que lhe são comuns: altitudes médias, clima temperado, relevo acidentado, revestimento natural de florestas subtropicais. Comercialmente orienta-se para o Rio de Janeiro, que é o porto de escoamento do produto, e por isso seu centro financeiro e controlador (...). Atinge, também, pela mesma época, o auge de seu desenvolvimento; logo 
virá o declínio. Repetia-se mais uma vez o ciclo normal das atividades produtivas do Brasil: a uma fase intensa e rápida de prosperidade, segue-se a outra de estagnação e decadência. Já se vira isso (sem contar o longínquo caso do pau-brasil) na lavoura de cana-de-açúcar e do algodão no Norte, nas minas de ouro e diamantes do Centro-Sul. A causa é sempre semelhante: o acelerado esgotamento das reservas naturais por um sistema de exploração descuidado e extensivo. (p.162)

Assim sendo, o Brasil deterá por quase três quartos de século o café como o instrumento concentrador de renda. Prado Jr (2012) afirma "a famosa frase, O Brasil é o café pronunciada no Parlamento do Império e depois largamente vulgarizada na República, correspondia então legitimamente a uma realidade: tanto dentro do país como no conceito internacional o Brasil era efetivamente, e só, café.” (p. 167).

O mapa abaixo talvez reflita qual (ou o que) era o Brasil pensado pelo grupo dominante à época: um país continental reduzido a um pequeno trecho.

Figura 1 - Produção de café no Brasil meridional durante o século XIX

Fonte: Prado Jr. (2012, p. 163)

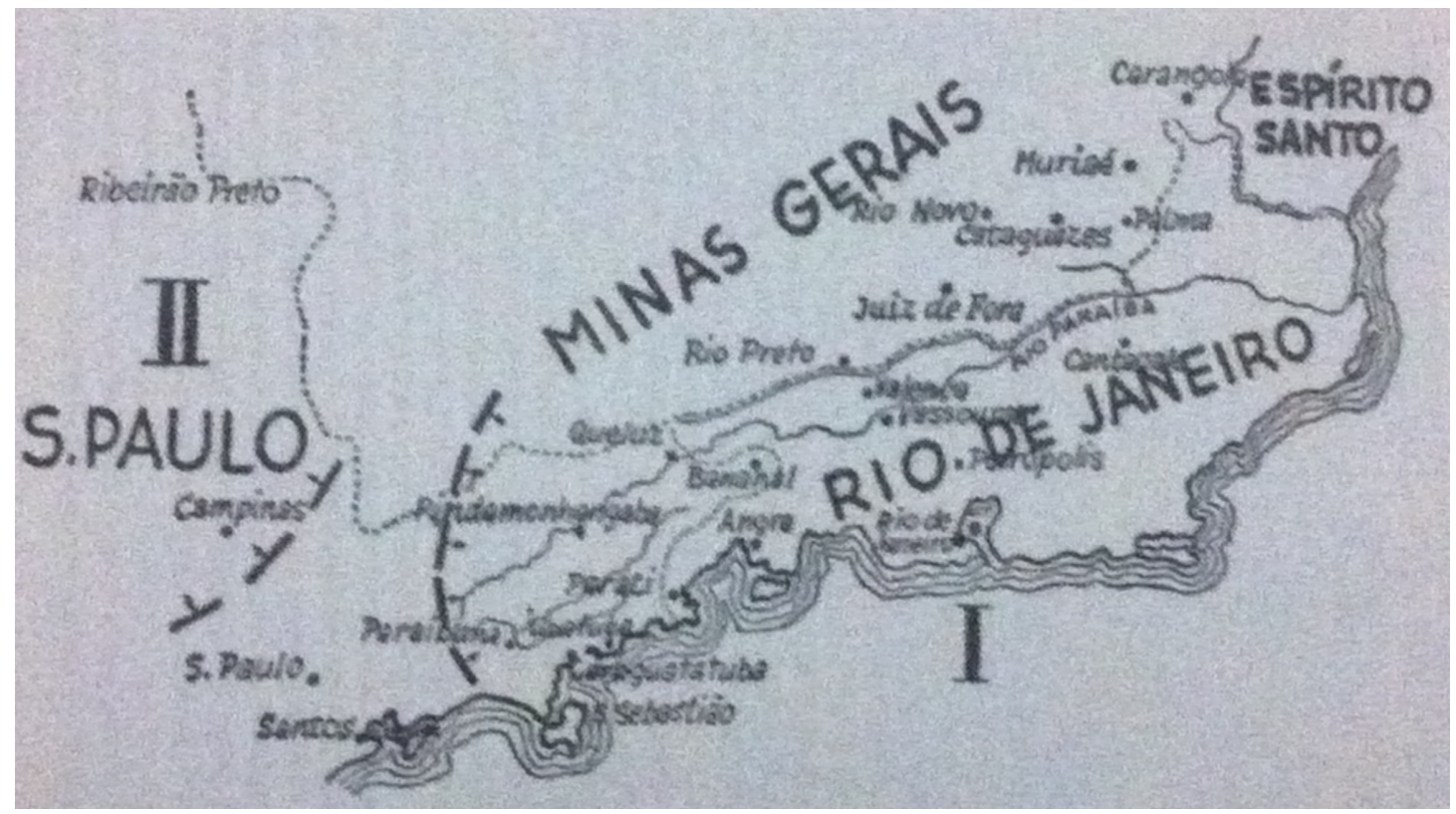

Delfim Netto, na principal obra sobre o impacto do café na historiografia econômica brasileira, O Problema do Café no Brasil (1959/2009), oriunda da sua tese de doutoramento confeccionada nos anos de 1950, separa a produção e mercado cafeeiro 
em duas grandes fases: a primeira, de 1857-1906, período sem intervenção estatal e a segunda, de 1906 a 1957 com intervenção do governo central. Falemos brevemente desse primeiro período.

A primeira fase (1857-1906), a relevante para esse trabalho, é dividida em três ciclos: (i) $1857-1868$; (ii) $1869-1885$ e (iii) $1886-1906$.

Nessa direção, Netto (2009) elucida que a "análise do mercado cafeeiro anterior à intervenção governamental (iniciada em 1906) (...) objetiva, principalmente, tentar distinguir um comportamento cíclico que se espera que exista.” (p. 13). A variável levada em consideração é o movimento oscilatório do preço do café.

A Figura 2 elucida o preço da importação dos Estados Unidos (principal proxy para o preço do café adotada por Delfim, por questões metodológicas) para o período da pesquisa:

Figura 2 - Preço da Importação do café nos EUA entre 1850 e 1950

(Fonte: Netto, 2009, p. 13)

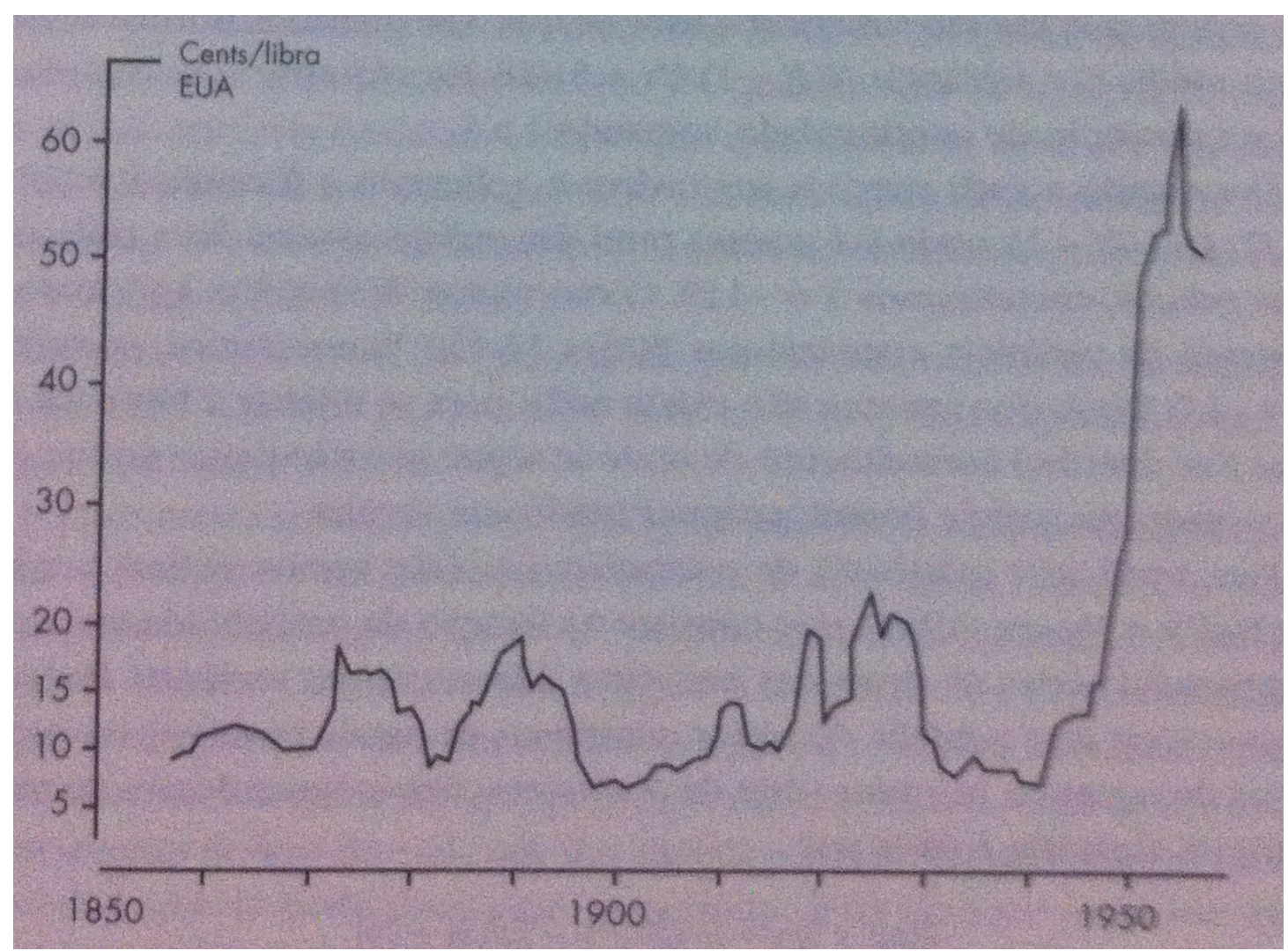


Para o período antes da intervenção (1857-1906), Netto (2009) identifica algumas características. A primeira, os preços flutuaram sem apresentar qualquer tendência secular. Em segundo lugar, as flutuações apresentadas dão clara indicação de que existe um movimento oscilatório, explicados pela interação entre oferta e demanda do café. O quadro abaixo resume os ciclos antes da intervenção oficial:

Quadro 5 - Os ciclos do período pré-intervenção oficial (1857 - 1906)

\begin{tabular}{|c|c|c|}
\hline Ciclo & Período & Características \\
\hline \multirow{2}{*}{$\begin{array}{l}\text { Primeiro } \\
\text { ciclo }\end{array}$} & \multirow{2}{*}{$\begin{array}{l}1857- \\
1868\end{array}$} & Fase ascedente: inovações merceológicas na produção \\
\hline & & $\begin{array}{l}\text { Fase descedente: Guerra do Paraguai (América do Sul) e da Secessão } \\
\text { (EUA) }\end{array}$ \\
\hline \multirow{2}{*}{$\begin{array}{l}\text { Segundo } \\
\text { ciclo }\end{array}$} & \multirow{2}{*}{$\begin{array}{l}1869- \\
1885\end{array}$} & Fase ascedente: quebra da safra brasileira e da América Central \\
\hline & & Fase descedente: exportações constantes, mas com crise cambial \\
\hline \multirow{2}{*}{$\begin{array}{l}\text { Terceiro } \\
\text { ciclo }\end{array}$} & \multirow{2}{*}{$\begin{array}{c}1886- \\
1906\end{array}$} & $\begin{array}{l}\text { Fase ascedente: quebra da safra brasileira e fim das crises americanas e } \\
\text { européias }\end{array}$ \\
\hline & & Fase descedente: superprodução, culminando na intervenção estatal direta \\
\hline
\end{tabular}

Quando se fala do primeiro ciclo (1857 a 1868), o aumento percebido nos preços se deu pela recuperação da economia europeia, pela infestação da elachista coffella na lavoura nacional, bem como a promulgação da Lei Eusébio de Queiroz (1850) que limita a utilização (e encarece) de escravos, já que o desembarque se tornou proibido.

Nessa primeira fase, o Brasil entrou num processo de dinamização das atividades econômicas e como apontado por Prado Jr. (2012) fundaram-se 62 empresas industriais, 14 bancos, 3 caixas econômicas, vinte companhias de navegação a vapor, 23 de seguros, 4 de colonização, 8 de mineração, 3 de transporte urbano, 2 de gás e 8 de estradas de ferro. Porém muitas dessas iniciativas são oriundas do surto de especulação e súbita liberação de capitais, através da emissão de papel-moeda por parte dos bancos e demais companhias detentoras do benefício.

Porém esse cenário de preços altos e estabilização da taxa cambial estimulou em muito a mobilização de mão-de-obra, mais notadamente São Paulo, que entra com todo o vigor na produção.

Mas todo esse progresso é interrompido de maneira mais profunda quando da Guerra do Paraguai, que embora vitorioso saia arrasado. (Prado Jr., 2012) 
Mesmo a Guerra do Paraguai (1864 - 1870) na América do Sul quanto a da Secessão na do Norte (1861 - 1865) causaram impactos não tão violentos no preço da mercadoria, já que em 1865 houve talvez a principal modificação merceológica: o café deixa de ser vendido verde para ser torrado posteriormente pelos consumidores e passa a ser vendido já torrado e em pacotes, resolvendo dois grandes problemas: aroma e paladar. Isso permitiu a padronização do produto, o que facilitou o desenvolvimento da cultura cafeeira em vários territórios (Netto, 2009).

Veja pela Tabela 1 abaixo, que mesmo com essas duas guerras, a exportação no período se manteve relativamente constante:

Tabela 1 - Exportação de café entre 1857 e 1869 (em 1 milhão de sacas)

Fonte: Netto, 2009, p. 20

\begin{tabular}{|c|c|c|}
\hline Anos & Europa & Estados Unidos \\
\hline 1857 & 1,5 & 1,1 \\
\hline 1858 & 0,8 & 1,4 \\
\hline 1859 & 1,1 & 1,4 \\
\hline 1860 & 1,4 & 1,4 \\
\hline 1861 & 1,6 & 0,9 \\
\hline 1862 & 1,3 & 5,0 \\
\hline 1863 & 1,2 & 0,5 \\
\hline 1864 & 1,1 & 0,7 \\
\hline 1865 & 2,3 & 0,9 \\
\hline 1866 & 1,3 & 1,0 \\
\hline 1867 & 1,7 & 1,5 \\
\hline 1868 & 1,4 & 1,4 \\
\hline 1869 & 1,6 & 1,5 \\
\hline
\end{tabular}

Com o fim da Guerra do Paraguai em 1870 começou a se restabelecer o fornecimento à América do Norte, que já era o principal importador, bem como a Alemanha. 
Passamos um período que teria de tudo para ser extremamente conturbado, com razoável tranquilidade, se assim se pode falar.

O segundo ciclo (1869 a 1885) assiste a uma interrupção da produção mundial que vinha aumentando de maneira robusta, devido a quebra da safra brasileira e da América Central, que junto com o aumento do consumo manteve a elevação dos preços em níveis violentos até 1874. Delfim aponta que as exportações do Brasil tinham a média de 3,6 milhões de sacas ao ano entre 1868-1871 e atingiram 3,3 milhões entre 1873-76: nessa direção os preços dobraram entre os dois períodos, aumentando consequentemente a receita de exportações nessa mesma faixa, em que o café representa $60 \%$ da nossa pasta de produtos vendidos para o estrangeiro. Mas a crise de 1873 (Primeira Crise do Capitalismo, 1873 - 1896) trouxe impactos também ao preço do café acompanhado em nosso país de uma diminuição do câmbio, mas as exportações se mantinham constantes, muito em decorrência da importação dos EUA (Netto, 2009), como mostra a tabela abaixo:

Tabela 2 - Variáveis selecionadas de 1874 a 1882

Fonte: Netto, 2009, p. 20

\begin{tabular}{|c|c|c|c|}
\hline Anos & Câmbio médio & $\begin{array}{l}\text { Preço médio do café por } \\
10 \mathrm{~kg}^{11}\end{array}$ & $\begin{array}{l}\text { Exportação em } 1 \mathrm{~mm} \\
\text { de sacas }\end{array}$ \\
\hline 1874 & $2423 / 32$ & $7 \$ 257$ & 2,67 \\
\hline 1875 & $277 / 32$ & $5 \$ 597$ & 3,15 \\
\hline 1876 & $2511 / 32$ & $5 \$ 293$ & 3,76 \\
\hline 1877 & $249 / 16$ & $6 \$ 290$ & 2,85 \\
\hline 1878 & $2215 / 16$ & $5 \$ 244$ & 3,03 \\
\hline 1879 & $213 / 8$ & $5 \$ 374$ & 3,54 \\
\hline 1880 & $223 / 32$ & $5 \$ 087$ & 3,46 \\
\hline 1881 & $215 / 8$ & $4 \$ 123$ & 4,38 \\
\hline 1882 & $215 / 32$ & $3 \$ 303$ & 4,20 \\
\hline
\end{tabular}

\footnotetext{
${ }^{11}$ Moeda brasileira no período da pesquisa é o Real (plural Réis), mesma denominação da moeda portuguesa, substituída pelo cruzeiro em outubro de 1942. Há a notação conto de réis, para indicar 1 milhão de réis (1:000\$000 ou Rs 1.000.000). Também há a notação mil-réis indicando 1\$000 ou Rs 1.000. (Souza, 1994).
} 
Netto (2009) aponta que "num período de 18 anos, que revela, nos primeiros 7, uma violenta elevação de preços e, nos 11 seguintes, uma baixa das mesmas proporções, a produção e o consumo não cessaram de crescer, passando de 6,6 milhões de saca em 1868-69 para 11,5 milhões de sacas em 1884-1885.” (p. 26).

Segundo Netto (2009), o terceiro ciclo (1886-1906) inicia seu primeiro ano com "uma nova e violenta fase de expansão" de preços. (p. 27). Essa se explica pela quebra de metade da safra em 87-88, a superação das crises americanas (84) e europeia (82), aumentando deveras o rendimento do consumidor e os preços do café. Netto (2009, p. 27) também destaca o incremento do impulso com a libertação da mão-de-obra escrava em 1888, que foi um passo decisivo na transferência da lavoura do Rio para São Paulo.

Nesses primeiros anos da República, Prado Jr. (2012) afirma que “o capital estrangeiro e o Estado tomam-nos a seu cargo.” (p. 195)

Netto (2009) aponta que no período entre 1890 e 1894, os preços haviam se mantido, mesmo com o aumento da oferta, mas devido à crise estadounidense e com o aumento da produção nacional (plantados sob o estímulo da alta), eles começaram a cair consequentemente.

Essa queda nos últimos anos do período sem a intervenção estatal não é explicada por Netto (2009) tanto pelo aumento da oferta, mas sim "pela folga que havia sido deixada pela depreciação do câmbio em condições de grande equilíbrio estatístico." (p. 33).

Na dimensão política e social foi a mesma coisa.

Conforme Prado Jr (2012), o café originou a última das três grandes aristocracias do nosso território, após os donos de engenho do nordeste (séc. XVI a XVII) e os empresários da mineração (séc. XVII e XVIII): os fazendeiros se tornaram a elite social brasileira. Esse fato é fundamental no entendimento de nossa ideia de pesquisa, já que toda a discussão e ação tanto econômica quanto social desempenhada no período do trabalho focou o benefício desses fazendeiros, quer estipulado oficialmente pelo governo, como de maneira indireta, inclusive com a participação do Banco do Brasil. O autor continua destacando que devido ao café São Paulo é o que hoje o é: "e na vanguarda desse movimento de ascensão, e impulsionando-o marcham os fazendeiros e seus interesses." (p.169). E mais: quase todos os fatos econômicos, 
sociais e políticos até 1930 mais ou menos se desenrolam em função do café. Porém esses grandes fazendeiros e o Brasil, em consequência, estavam a mercê dos interesses capitalistas ingleses que financiaram o nosso país, com somas jamais vistas (mais de 60 milhões de libras até o fim do Império), inclusive via Banco do Brasil em vários anos de nosso estudo.

Assim, o café tem um papel fundamental principalmente para as classes aristocráticas e dominantes, já que com os constantes superávits decorrentes da exportação da nossa monocultura de exploração do momento permitem esse Brasil conhecer sobretudo após 1860 um padrão de vida a que ainda não havia sido submetido, com certo progresso e bem-estar material. Começamos a acompanhar (importando a grandes somas) os benefícios da Revolução Industrial: construção de ferrovias, introdução de maquinofatura, comunicação e transportes, etc. Da grande massa de brasileiros, a minoria teve acesso a todos esses desenvolvimentos.

Além dos grandes e tradicionais fazendeiros do nordeste da antiga riqueza do pais, o açúcar, nascia a pequena burguesia sobretudo na Corte e depois em São Paulo: os grandes, pequenos e médios produtores da nova riqueza nacional e toda a indústria ligada à sua necessidade, o café. Esses eram a elite nacional no século XIX, somados com a própria corte. Porém, diferentemente dos países europeus, ainda éramos um Estado de cunho absolutista: vide que mesmo com a Independência em 1822, fomos regidos por um Imperador até 1889 (Alencar, Carpi \& Ribeiro; 1994):

Para a aristocracia agrária que conduzia o movimento da independência, a liderança de D. Pedro cumpria uma papel fundamental: significava a manutenção da monarquia, de preferencia unitarista, que impediria ou frearia as possibilidades mais revolucionárias, isto é, abolicionistas. (p. 108).

Viotti da Costa (2010) traz um panorama da elite brasileira que "toma o poder em 1822 ", composta por fazendeiros, comerciantes e sua clientela, ligados intimamente à dinâmica da importação/exportação, interessados, sobretudo "na manutenção das estruturas tradicionais de produção cujas bases eram o sistema de trabalho escravo e a grande propriedade.” (p. 11). Ocorre, na visão da autora, a expurgação de pensamentos liberais e dotação de um espírito antidemocrático, elitista, inclusive com a subordinação da Igreja ao Estado. 
Verifica-se um fato inusitado em nosso primeiro império, conforme Viotti da Costa (2010). já que os críticos do poder central quando o tomavam, tornaram-se conservadores: nos anos que se seguiram, mesmo revezando os gabinetes liberal ou conservador, mesmo estando em grupos antagônicos, "mantiveram concordância a respeito de questões tais como a manutenção da economia agrária e da escravidão." (p. 13).

Mas na formação da elite brasileira no século XIX, Viotti da Costa (2010) afirma que esta se afastava ou "adotava uma posição ambígua em relação á ética burguesa e ao capitalismo", já que esse primava pelo "culto à liberdade individual, na valorização do trabalho e da poupança", fato esse que "não fazia muito sentido numa sociedade em que o trabalho era feito por escravos, as relações humanas se definiam em termos de troca de favores e a mobilização social dependia da patronagem da elite.” (p. 13).

Assim, na visão da autora, "o Império foi cabide de empregos, os burocratas sujeitos ao capricho da política e ao revezamento dos partidos no poder." (p. 13).

Inclusive aquela parcela da população mais esclarecida, denominado bacharéis, com formação superior, algo tão incomum naqueles tempos em terras nacionais, segundo Viotti da Costa (2010) não se opuseram ao patriarca, mas ao contrário, foram elemento de conciliação de interesses.

Porém, segundo Alencar, Carpi e Ribeiro (1994) o poder do Imperador continuava grande, já que pela Carta de 1824 era tido como "sagrado e inviolável", inclusive com a criação do Poder Moderador, de atribuição do Augusto Imperador, que tinha poderes exclusivos, como por exemplo dissolver a Câmara e sancionar decretos. (p. 119).

Mesmo com a Independência, era extremamente interessante para a Inglaterra que o Brasil permanecesse como uma monarquia, com o medo da crescente do bloco republicano liderado pelos Estados Unidos. (Alencar, Carpi \& Ribeiro, 1994).

Com a abdicação de Pedro I em 1831, Sodré (1969) elucida que este estava desgastado "profundamente, tornou-se inválido para servir aos propósitos conservadores da classe que empresara a autonomia e que dele se servira, chocandose com muitos de seus melhores e mais poderosos representantes." (p. 189). Adicionalmente, segundo Alencar, Carpi e Ribeiro (1994) a abdicação efetivou e 
consolidou o poderio na mão dos grandes latifundiários do sudeste brasileiro, "que poderiam agora reconstruir o Império à sua maneira.” (p. 134).

Momentos conturbados, já que o herdeiro do trono ainda era uma criança de 5 anos. Muitas revoluções em vários cantos no país...Cabanada, Praieira e Balaiada são exemplos dessa agitação política e econômica. Vivíamos o Período Regencial (provisória, trina e una, respectivamente).

As enormes dificuldades do período fizeram com que muitas figuras importantes da cena política brasileira, como Paulino Soares e Eusébio de Queiroz, negociassem a antecipação da maioridade de Pedro II, agradando tanto conservadores como liberais: em 23 de julho de 1840, o menino Pedro pronuncia o famoso: “quero já!”. A opção parlamentarista brasileira iniciada em 1840 era sensivelmente diferente do modelo clássico inglês, já que confere grande poder na mão do Imperador, através do Poder Moderador. Porém, diferentemente de seu pai, Pedro II usou o poder Moderador em sintonia com os interesses dos partidos constituídos, com intuito de eliminar ou reduzir qualquer liberalismo mais radical. Esses, no ano de 1868, após a dissolução da Câmara pelo imperador, formou-se o Partido Liberal Radical, gênese do futuro Partido Republicano. (Alencar, Carpi \& Ribeiro, 1994).

Nesse tocante, Alencar, Carpi e Ribeiro (1994) elucidam que o fortalecimento dos laços militares com a vitória na Guerra do Paraguai em 1870 "traria sérias questões políticas para a monarquia.” (p. 193).

A questão mais importante era a mão-de-obra escrava.

Além dos brasileiros livres fora da aristocracia cafeeira, um grande massa era totalmente excluída e sujeita aos mais perversos castigos que uma pessoa pode fazer a outra (perceba o cunho necessariamente econômico capitalista dessa relação): os escravos. Não cabe aqui nessa tese discutir os aspectos psicológicos e sociais do ato de escravizar uma pessoa: vou focar na sua dimensão infinitamente menor, contudo infinitamente maior no tratamento pelos estudiosos, a dimensão econômica da cessação oficial das atividades escravocratas em nosso território.

Corroboramos com a visão de Florestan Fernandes (1972) de que o negro, tanto o cativo quanto o alforriado eram corpos estranhos à sociedade brasileira no século XIX: era "como se estivesse dentro dos muros da cidade, mas não participasse coletivamente de sua vida econômica, social e política.” (p. 82) 
Toda a questão do fim da escravidão, desde o tráfico, dos nascidos, dos sexagenários e finalizando com a completa abolição, um fato é curioso em nossa história econômica já que muitos afirmam o grande desenvolvimento que o país passou com o término dessa injustiça social e humana. Permitiu ilusoriamente a criação de instituições privadas, decorrentes do acúmulo de capital outrora empregado no tráfico de pessoas oriundas da África. Também cria uma relação capitalista mais clássica quando começa a pagar, o famoso trabalho assalariado.

Essa dimensão da atividade humana cresce muito no Brasil, mais notadamente após 1880 , fato esse que caracteriza muito do que criamos como conceito de trabalho em nossa sociedade atual. Caio Prado Jr. (2012) destaca em muitas passagens do História Econômica uma certa vergonha e descalabro de membros de nossa administração oficial acerca da questão da abolição, fato esse que corrobora a tese de não interesse no fim da mesma, já que ia contra seus anseios econômicos. O próprio desenvolvimento e quebra posterior das instituições bancarias e de créditos no país são explicados pelos capitais especulativos outrora empregados no tráfico negreiro.

A escravidão não degradava somente os negros, mas toda a nação: a questão dos negros não era nova, já que desde princípios do século XIX o Brasil era forçado, mais notadamente pela Inglaterra na abolição da escravatura. A própria expansão do café trazia a tona a problemática, já que era necessário mais mão-de-obra. De duas uma: ou mais escravos ou braços livres. Em 1822, ano da independência, segundo Alencar, Carpi e Ribeiro (1994), metade da nossa população era composta por escravos, “sendo que em 1850 esse número alcança a marca de 2,5 milhões de pessoas." (p. 169). Como bem pontua Furtado (2007):

Mais que em qualquer outra matéria, nesta dificilmente se conseguem separar os aspectos exclusivamente econômicos de outros de caráter social mais amplos. Constituindo a escravidão no Brasil a base de um sistema de vida secularmente estabelecido, e caracterizando-se o sistema econômico escravista por uma grande estabilidade estrutural, explica-se facilmente que para o homem que integrava esse sistema a abolição do trabalho servil assumisse as proporções de uma "hecatombe social". Mesmo os espíritos mais lúcidos e fundamentalmente antiescravistas, como Mauá, jamais chegaram a compreender a natureza real do problema e se enchiam de susto diante dessa "hecatombe" inevitável. Prevalecia então a ideia de que um escravo era uma "riqueza" e que a abolição da 
escravatura acarretaria o empobrecimento do setor da população que era responsável pela criação de riqueza no país. ( p. 199).

Um primeiro ponto a ser tocado deve ser efetuado em respeito a questão da mão-deobra, já que a população livre brasileira, tanto as oriundas das zonas urbanas quanto aqueles oriundas da agricultura de subsistência tinham dificuldade no tocante a adaptação às condições de vida na fazenda em relação à disciplina que o trabalho agrícola requeria: Furtado (2007) ensina que esse fato contribuiu para formar a opinião de que a mão-de-obra livre do país não servia para a grande lavoura." (p. 176): a solução alternativa era desenvolver a imigração europeia. Porém o mesmo autor aponta que "não havia precedente, no continente, de imigração europeia de mão-de-obra livre para trabalhar em grandes plantações.” (p. 181).

Alencar, Carpi e Ribeiro (1994) apontam que Brasil e Inglaterra viviam em clima de guerra: o Império teve que ceder, mesmo com resistência dos fazendeiros, emitindo diversas regulamentações emancipatórias antes da abolição propriamente dita, como por exemplo a Lei Eusébio de Queirós de 1850, que proibia o tráfico; a Lei do Ventre Livre de 1871, alforriando os nascidos e a Lei dos Sexagenários de 1885, alforriando os escravos idosos. O próprio imperador identificava-se com a causa abolicionista desde a década de 50.

Dessa forma, a suspensão do tráfico ao mesmo tempo que aliviaria a questão diplomática, adicionalmente criaria um mercado interno, que poderia beneficiar tanto os produtores do Norte (que venderiam seus escravos) como para os do Centro-sul, que os comprariam. Entretanto, conforme levantado por Prado Jr. as regulamentações pré lei Áurea, como a Lei do Ventre Livre, resultaram, na visão de Prado Jr. (2012) em uma "última análise, senão numa diversão, uma manobra em grande estilo que bloqueou muito mais que favoreceu a evolução do problema escravista no Brasil.” (p. 179). O autor calcula que nessa direção a escravidão demoraria de 50 a 60 anos para desaparecer no país!

Mas nessa mesma época a questão da imigração toma corpo novamente, com a intensificação dos desembarques em terras nacionais: somente em São Paulo o número de imigrantes sobe de 13 mil imediatamente após os anos 50 para 184 mil nos 80 e no último decênio do século para 609 mil. (Furtado, 2007). 
A partir da segunda metade do século XIX, a expansão do mercado internacional e a revolução nos sistemas de transportes impactaram de sobremaneira e abriram novas possibilidades para a cultura cafeeira nacional, tornando a imobilização do capital em escravos menos produtiva. Viotti da Costa (2010) afirma que os fazendeiros dessas novas áreas do Sudeste, já certos da questão da abolição do tráfico, foram em defesa da proposição de legislação mais aberta, e de mais fácil acesso às terras por parte dos imigrantes, trabalho este que parecia ser mais lucrativo em certas áreas.

Inicialmente, foram testados as colônias de parceria, que espalhou-se rapidamente por São Paulo, resolvendo temporariamente a questão da mão de obra. Essa métrica se tornou extremamente onerosa para o colono, que assumia quase uma dívida interna com os fazendeiros, ligados à política e repressão policial. (Alencar, Carpi \& Ribeiro; 1994).

Com o fracasso desse método, o Governo iniciou a imigração subvencionada, em que o Estado assumiria as despesas de viagens das famílias e os recrutariam para as fazendas. Furtado (2007) ensina que o papel do poder político foi fundamental para esse sistema de colonato: a "classe dirigente da economia cafeeira passou a preocupar-se diretamente com o problema.” (p. 184).

Mas devido à precariedade da dinâmica econômica, já que não havia mercado interno para os excedentes da produção: assim, a possibilidade de desenvolver esse, dependia da expansão do setor de exportação; na visão de Furtado (2007) mas como "a chave do problema era a oferta da mão-de-obra retornava-se ao ponto de partida. (p. 184).

Inclusive, as primeiras experiências desse trabalho livre no Brasil suscitavam muitas dúvidas no continente europeu, devido às notícias de semiescravidão, ou escravidão disfarçada. (Furtado, 2007).

No terceiro quartil do século XIX, a corrente imigratória ganha grande força, devido ao sistema de pagamentos ao colono, no qual esse tinha garantida parte de sua renda, recebendo um salário anual fixo por cuidar de um determinado número de pés e um pagamento variável, baseado no volume da colheita. Outro fator destacado para esse aumento, está na função do governo em propagar a imigração para o país, inclusive encarregando-se dos gastos dos imigrantes em relação ao custo da viagem. Além disso, a própria questão da unificação política da Itália facilitou a onda imigratória para o Brasil. (Furtado, 2007). 
Após algumas experiências privadas com a questão dos imigrantes, tais como as fazendas do Senador Vergueiro na primeira metade do século XIX, esse segundo processo, de maior sucesso, denomina-se imigração subvencionada. (Prado Jr. 2012). Lamounier (2007) destaca que a grande mobilidade dos trabalhadores rurais entre 1850-1890 na produção de café e também na construção de rodovias era decorrente da não geração de serviço durante o ano todo, em que eram adotadas medidas repressivas a fim de conter essa onda de instabilidade e mobilidade de mão-de-obra.

Nesse ponto, cabe discutirmos a transição do trabalho negro-escravo para aquele denominado livre. Para isso, nos apoiaremos na visão de José de Souza Martins na sua obra $O$ Cativeiro da Terra (1986).

No referido livro, o autor questiona a visão clássica de que a crise no trabalho escravo decorrer a substituição para o trabalho livre: para o mesmo, esse processo foi extremamente lento e decorrente das redefinições das relações sociais emanadas pelo capitalismo. Nesse sentido, a ideia do trabalho livre era mais ideológica que de fato, já que o trabalhador ainda era explorado, porém acreditando estar livre (Martins, 1986).

No mesmo movimento, algumas comunidades negras campesinas, substituídas pela força livre de trabalho, criaram comunidades, geralmente chefiadas e lideradas por um messias, pessoa essa de grande poder carismático, capaz de orientar para uma ordem social mais justa, que foram duramente combatidas por forças militares republicanas. (Martins, 1986).

Segundo Viotti da Costa (2010), o papel dos esclarecidos, ganha força nos anos de 1870-89, quando começam a participar dos movimentos reformistas, sendo que essa adesão dos bacharéis, "se dá no momento em que os setores novos das elites agráriomercantil-exportadoras se lançam num projeto de modernização relativa do país e disputam o poder às elites tradicionais.” (p. 14).

Nos anos 80, os climas escravocrata e monárquico estavam desgastados, perdendo apoio em todos os cantos da sociedade. Aos 13 de maio de 1888, a princesa Isabel assinava a Lei Áurea. Para Alencar, Carpi e Ribeiro (1994) isso significou a liberdade legal dos negros, mas não de vida, pois foram jogados às traças e sem nenhuma forma de integração à sociedade, pouco contribuindo "para terminar com a ideia da inferioridade do negro (...) agravou ainda mais a marginalização das populações negras.” (p. 207). O preconceito racial foi reforçado de maneira importante. 
Nesse certame, Viotti da Costa (2010) analisa que o progresso da economia brasileira da segunda metade do século acarretou profundo desiquilíbrio entre poder econômico e poder político: aquele sistema de 1822 parecia inapropriado nos anos 80 , já que as novas elites urbanas não se sentiam representadas de maneira suficiente e os fazendeiros das áreas cafeeiras, produtores de boa parte da riqueza do país, "sentiamse peados pelas estruturas políticas do Império.” (p. 17).

E um ano depois, com o apoio da nova burguesia paulista e do fortalecido exército tomam o poder sem maiores resistências. A república era uma necessidade: ela proporcionaria a descentralização do poder. (Alencar, Carpi \& Ribeiro, 1994).

Contudo, mesmo com algumas tentativas de mobilização da população, a nossa primeira República tal como no movimento de Independência se fez sem a colaboração das massas. (Viotti da Costa, 2010).

No mesmo caminho, Werneck Vianna e Carvalho (2000) argumentam acerca da nossa passagem para a República que:

A herança do patrimonialismo, originária de processos societais derivados do exclusivo agrário, significava uma república de poucos - oligarquia que se tornava tão mais anacrônica quanto mais se modernizava e se complexificava a estrutura social do país. Esgotava-se, enfim, a matriz civilizatória das antigas elites socializadas no Império, e a ordem racional-legal se torna uma dimensão vazia de sentido, com o direito se aviltando em um maneirismo de bacharéis. Prisioneira da hipoteca ao patrimonialismo, a ordem racionallegal, ao conceber uma república sem democracia e sem incorporação social, cristalizou o liberalismo como ideologia de elites, sem desenvolver as suas potencialidades universalistas, em termos de direitos civis. E foi nessa recusa à inovação, mantendo-se indiferente às pressões dos novos setores emergentes, como empresários, militares, classes médias e operariado urbanos, que o ideário liberal, força subterrânea que presidiu o longo processo de transformações moleculares ao longo do período anterior, perdeu substância, frustrando as expectativas de uma plena passagem do país a uma ordem social competitiva. (p. 29). 
Nos governos militares e mais destacadamente, naquele da Oligarquia do Café, a penetração dos interesses dos cafeicultores toma uma dimensão ainda maior, como o caso da eleição de Campos Sales, representante do Partido Republicano Paulista. 


\section{2 - UMA BREVE HISTÓRIA DO BANCO DO BRASIL E SUAS RELAÇÕES COM AS SOCIEDADES POLÍTICA E CIVIL (1853 - 1902)}

Antes de adentrarmos na fase relevante para essa pesquisa, é fundamental falarmos da vida do banco em seu primeiro nascimento. O quadro abaixo resume os principais eventos em questão:

Quadro 6 - Os diversos Bancos do Brasil

\begin{tabular}{l|l}
\hline Ano & Evento \\
\hline 1808 & Fundação do primeiro Banco do Brasil por D. João VI \\
\hline 1829 & Liquidação por lei do primeiro Banco do Brasil \\
\hline 1851 & Fundação do segundo Banco do Brasil pelo Barão de Mauá (privado) \\
\hline 1853 & $\begin{array}{l}\text { Fundação do novo Banco do Brasil com intervenção imperial, através da fusão do Banco do Brasil } \\
\text { de Mauá e o Banco Commercial do Rio de Janeiro }\end{array}$ \\
\hline 1893 & $\begin{array}{l}\text { Fusão do Banco do Brasil com o Banco da República dos Estados Unidos do Brasil, com nova } \\
\text { denominação, Banco da República do Brasil }\end{array}$ \\
\hline 1905 & $\begin{array}{l}\text { Por decreto de dezembro desse ano, volta a ter o nome de Banco do Brasil, que se mantém até os } \\
\text { dias atuais }\end{array}$ \\
\hline
\end{tabular}

A primeira fundação do Banco do Brasil monta ao ano de 1808, formado por um capital de 1.200 contos de réis, divididos em 1.200 ações com valor nominal de 1 conto cada. Segundo tal documento, as operações da instituição consistiam, então, no desconto mercantil de letras de câmbio sacadas ou aceitas por negociantes de crédito, nacionais ou estrangeiros; na comissão dos cômputos arrecadados de particulares ou estabelecimentos públicos, ou adiantados através de hipotecas; no depósito geral em prata, ouro, diamantes ou dinheiro; na emissão de letras ou bilhetes pagáveis ao portador, no mínimo de 30 mil réis; na comissão dos saques particulares ou do Real Erário, de fundos localizados no estrangeiro ou nacional, em área remota; no recebimento de toda a soma, que se lhe oferecesse a juro da lei; na comissão da venda dos gêneros privativos dos contratos e administração reais, como os diamantes, paubrasil, marfim e urzela; no comércio das espécies de ouro e prata. Mesmo assim, porém, uma de suas tarefas, não elucidada nos seus estatutos, durante esses primeiros anos de existência era o fornecimento de capital para cobrir os gastos da enorme corte trazida ao país, fato este que levou ao fechamento do banco em 1833, devido a grande quantidade de saques efetuados pelos membros ligados à Corte. (Cardoso, 2010). A 
instituição nesse primeiro período fora usada como meio de financiamento de uma classe apenas, a nobreza.

Melo Franco (1947) aponta que o problema do meio circulante também já era sentido em Portugal no fim do século XVIII, com a crise na exploração mineira brasileira: "com a vinda da corte portuguesa para o Brasil, a necessidade de aumento do meiocirculante, que já premente na Metrópole e na Colônia, tornou-se ainda maior.” (p. 21).

Costa Neto (2004) ainda lembra que nessa primeira fase inúmeros favores foram concedidos ao banco, tais com a emissão de notas bancárias, isenção de todo e qualquer tributo e monopólio sobre a comercialização de vários produtos.

E como bem lembrado por Souza Franco (1848), "não obstante tão valiosos privilégios concedidos por vinte anos, que tantos devia durar o estabelecimento, passou mais de ano antes que pudesse completar 1/10 do capital necessário (...)”. (p. 16). Além disso, foram tomadas algumas providências por parte do governo "para animar a empresa" e o alvará de 12 de outubro de 1812 criou impostos denominados do Banco, "sendo o dos primeiros cinco anos totalmente em benefício dos acionistas, e para que seus juros fizessem parte dos dividendos (...) e do segundo prazo de cinco anos reduzidos a ações por conta do Tesouro Real.” (p. 16).

Cardoso (2010) afirma que a ruina do Banco do Brasil se deu devido à soma entre a má administração (através de fraudes e presença maciça de relações pessoais e de favores) bem como uma má solução no tocante à moeda (através da emissão descontrolada de notas).

Mesmo já quando em estado de insolvência, os favorecimentos ao Banco ainda continuam, como por exemplo a deliberação de 28 de julho de 1821, tratando de suspender o troco dos bilhetes em metal, autorizando o banco a trocar em uma proporção diferente do anteriormente acordado. (Souza Franco, 1848).

Apesar dessa primeira quebra, Souza Franco (1848) afirma que "o Banco, ou seus acionistas foram os que lucraram vantagens importantes, e que as teriam ainda maiores, se melhor escolha dos empregados, e mais severa vigilância sobre seus atos tivessem prevenido as perdas de que eles foram causa. Ainda assim o dividendo anual do Banco foi avultado.” (p. 24). 
Assim, segundo Melo Franco (1947), em "nada temos que admirar, portanto, no fato de a crescente inflação de papel moeda constituir a constante, que seria monótona se não fosse trágica, da vida do primeiro Banco do Brasil.” (p. 28).

E como bem destacado pelo mesmo Melo Franco (1947):

Necessitando sempre de dinheiro, sobretudo depois da independência, o Governo passou a intervir abertamente na administração, apesar de não ter possuído senão um número reduzido de ações (...), nomeando discricionariamente administradores, suspendendo alguns favores, não cumprindo regularmente outros, diminuindo até o possível o valor nominal dos bilhetes (...), aumentando a seu talante as emissões, impedindo praticamente todas as transações com os particulares e não pagando as suas dívidas. Está claro que tudo isto se tornara inevitável (...). (p. 32).

O mesmo autor, em reflexão sobre essa primeira liquidação conclui que para os acionistas o curto período de vida do Banco do Brasil não foi assim de todo o ruim, já que após a dissolução do banco foram distribuídos aos acionistas $81 \%$ do seu capital, acrescido de um dividendo anual médio de 12,31\%. (Melo Franco, 1947).

Nessa fase até meados do século, o país viveria sem o Banco do Brasil e quase em instituições financeiras, já que apenas em 1838 surge o Banco Commercial do Rio de Janeiro. (Pacheco, 1973).

$\mathrm{Na}$ visão do autor, o período conturbado politicamente para o Brasil, com a Independência, a Regência e Governos Provisórios não criavam ambiente propício para o surgimento de um novo Banco do Brasil. (Pacheco, 1973).

O segundo nascimento do Banco do Brasil monta ao ano de 1851 promovido pelo Barão de Mauá, que dois anos depois efetuou a fusão da instituição com o Banco Comercial do Rio de Janeiro, tida como a primeira operação deste tipo da indústria bancária ocorrida no país. Iniciou suas operações dois anos depois, em 1853. (BB, 2010).

Não se deve confundir o Banco do Brasil de Irineu Evangelista (privado) com o surgido em 1851 ("público”). Da fusão desses dois bancos privados, nasceu o Banco do Brasil, "público ou misto", já que embora controlado societariamente por entes privados na era do Império, este tinha grande influência, através da indicação do 
presidente e vice-presidente da instituição, bem como nas definições e interferência nas políticas operacionais da mesma.

BB (2010) elucida que a operação foi encabeçada por José Joaquim Rodrigues Torres, o visconde de Itaboraí, com a objetivação de criar um banco de emissão e aumentar o crédito para as crescentes riquezas nacionais, porém "não podia ser oficial, pois o governo não poderia, sem abandonar a posição de protetor imparcial de todos os interesses da sociedade, encarregar-se de dirigir operações comerciais.” (p. 27).

Após a extensos debates e críticas no Senado e Câmara, a proposta ministerial foi aprovada sem muitas alterações. Através do decreto 1.222 de 31 de agosto de 1853 o plano de fusão foi aprovado pelo governo. (BB, 2010).

Percebemos que desde esse novo nascimento do Banco do Brasil, este já nasce com seus pilares formados pela ideologia privada, dado que é o produto da união de dois bancos privados (o Banco do Brasil de Mauá, que não era o público e o Banco Commercial, da cidade do Rio de Janeiro, também não público). Inclusive, a própria máquina administrativa nesses primeiros anos era a oriunda das duas instituições fundidas.

Como bem colocado por Pacheco (1973), o grande atraso no início do funcionamento do Banco (10 de abril de 1854) ocorria em um cenário em que:

Os Estatutos que acompanharam esse decreto tinham a dupla qualidade de lei orgânica da instituição e contrato bilateral entre o Governo e as administrações dos antigos estabelecimentos bancais existentes nesta Corte, devidamente autorizados por seus acionistas. (p. 158)

Nessa época, logo após o fim do período regencial brasileiro, além das desordens de cunho político, também existia a questão econômica e financeira, com o grande problema da circulação de moeda e crises inflacionárias.

Mais notadamente, as discussões travadas nas legislaturas brasileiras sobretudo após 1840, se davam em última análise em dois pontos: a questão da moeda e o papel dos bancos. Segundo Saez (2008): 
Os metalistas, por exemplo, defendiam o predomínio de moeda metálica, acreditavam no valor intrínseco dos metais preciosos como meio-circulante, nos benefícios que traria sua utilização como moeda e atrelavam a questão da taxa de câmbio à conversibilidade da moeda por um valor fixo em metal. Os pluralistas, por sua vez, acreditavam no predomínio da circulação do papel-moeda, nas facilidades de transação com esse tipo de moeda e na maior facilidade de expansão do crédito. $\mathrm{O}$ foco de sua preocupação era a circulação interna e para que o papel-moeda emitido não pesasse sobre o câmbio era necessário que as emissões não ultrapassassem a quantia necessária ao movimento da produção interna. Divergiam também quanto à idéia de formação do instrumento, ou sistema, que executaria a emissão do meio circulante e que seria a referência para o fornecimento de crédito. (p. 11)

Segundo BB (2010), os bancos criados nesse período podiam, segundo os estatutos aprovados pelo governo, emitir "vales ou letras ao portador e a prazo determinado, que acabaram circulando como moeda." Era uma atitude perigosa do governo nos olhos de alguns críticos que entendiam que a cunhagem de moeda deveria ser exclusiva do poder central. (p. 26).

Com esse objetivo, a ajuda do Governo Imperial também é notória através da rápida provisão de letras impressas para o Banco do Brasil no tocante às suas atividades, conforme Pacheco (1973). Aliás “folgo de poder declarar-vos (...) que neste e como em todos os outros casos em que teve a Diretoria de dirigir-se ao governo imperial, o encontrou sempre solícito em coadjuvá-la e protege-la.” (p. 159)

O objetivo final de Itaboraí era um banco concentrador, com o poder da unidade de emissão, acabando de alguma maneira com os males, sobretudo inflacionários, promovidos pelo descontrole na emissão de bilhetes por parte das mais diversas instituições. (BB, 2010).

Já em 1854, após o sucesso na emissão de suas ações já era comentado o grande sucesso do banco, aumentando de maneira importante a sua cotação na bolsa do Rio de Janeiro. (BB, 2010). Porém um fato curioso chama a atenção, já que a análise do primeiro balancete do Banco na edição de 29 de maio de 1854 do Jornal do Commercio concluiu que os lucros extraordinários não poderiam se manter tão elevados. 
Já em 1854 foram iniciadas as Caixas Filiais (Caixas Filiaes) nas províncias, com a de São Paulo, através da extinção do Banco da Província de São Paulo, com a criação em Ouro Preto e da conversão na província do Rio Grande do Sul. Outras conversões ocorreram, como as caixas filiais de Pernambuco, Maranhão, Pará e Bahia. Estas não eram agências propriamente ditas, já que gozavam de certa autonomia, com estatutos e diretoria próprios. Também nos seus primeiros anos iniciou-se a grande dinâmica e volumosas operações com o Tesouro, com taxas inclusive favorecidas quando comparadas com as demais operações do banco. (BB, 2010).

Alguns conflitos ocorrem, porém como bem pontuado por Gambi (2010):

Internamente, o fato de ser um banco privado abria uma brecha para ações independentes que desencadeavam conflitos com o Estado, mas não se tratavam de conflitos que pudessem levar ao rompimento da relação. Sua intensidade dependia do grupo político que estivesse no governo. Justamente por conta da divergência entre interesses públicos e privados, surgiam conflitos também entre acionistas e diretoria do banco. Em alguns casos, os acionistas serviam como massa de manobra política e, em outros, a diretoria procurava atender seus interesses, mas sem romper a relação com o governo, reclamando e obedecendo (grifo nosso). (p. 461).

As rusgas entre diretores se inicia e o Barão de Mauá, defensor da pluralidade de emissão, demite-se do cargo e cria novo estabelecimento através da sociedade em comandita, logo proibida pelo imperador de dividir o capital em ações, boicotando, assim, a empreitada. (BB, 2010).

A ganância rapidamente toma conta da instituição, através do fluxo de emissão que já se aproximava do limite estatutário, que era o dobro do fundo disponível. Esse fato começou a preocupar a diretoria, rompendo em março de 1855 o limite supracitado. Apelando ao ministro da Fazenda, foi autorizado o incremento para o triplo do fundo disponível por decreto $10.581 \mathrm{em} 2$ de abril de 1855, pedido feito novamente em 1856 por ter expirado a validade da autorização governamental. (BB, 2010).

Como bem lembrado por Souza Franco, no ensaio intitulado Os Bancos de Emissão no Brasil, obra de 1848, anos antes da segunda fundação do Banco do Brasil (Souza Franco, 1848, p. 9): 
São verdades hoje reconhecidas em todos os pontos do Império, como o atestam os bancos estabelecidos ou que se tenta estabelecer, e contudo, indispensável é que o Governo não abandone a si mesmo estes esforços da população brasileira e a não deixe exposta aos erros e desvios que o tirocínio e má-fé de outros lhe possam acarretar e que os coadjuvem com todas suas forças os entendedores e profissionais na matéria. Bem regulados e dirigidos os bancos podem ser de grande vantagem ao Império, e, pelo contrário, até nocivos se lhe tornaram, e muito ao Tesouro, acionistas e fregueses, se os consentirem abandonados aos estímulos desregrados do interesse privado e da ambição individual.

Severas críticas foram feitas, de acordo com BB (2010), inclusive na seção do Conselho de Estado que "deu parecer onde declarou que uma das causas da pressão do momento consistia na 'grande massa de transações fruto de jogatina, sobre as ações do Banco do Brasil (...)"” (p. 33).

O Banco alega a problemática de seu fundo disponível as constantes remessas efetuadas para as províncias da região norte, decorrentes do pagamento de escravos e de aplicações nas safras. Essa situação fazia com que o banco tivesse que importar ouro dos mercados estrangeiros, bem como adquiri-lo, mesmo que em menor parte no próprio território. $(\mathrm{BB}, 2010)$.

Com as más noticias vindas da Europa, decorrentes da baixa do câmbio e da suspensão da compra de café, a crise dos Estados Unidos, no período pré-guerra civil (1861-1865) e com a questão do fundo disponível, que se encontrava perto do limite legal, foram elevadas as taxas de juros em 1857 e 1858, bem como suspenderam-se alguns empréstimos. Diante de tal situação foi solicitado ao Império o consentimento para elevação da emissão ao quádruplo e realizar saques de moeda estrangeira em Londres, com a intenção de reduzir a queda do cambio, tão prejudicial às pretensões dos exportadores brasileiros de café. (BB, 2010).

Pacheco (1972) através do estudo das atas mostra que:

Disse ainda o Presidente, que mesmo que ao último dia do mês ocorresse alguma diferença para menos, ele, no oficio que dirigisse ao Governo remetendo-lhe o balanço mensal, explicaria o motivo dela e certo das benévolas intenções do Governo para com o Banco, estava persuadido de que não se recusaria a admitir (...). (p. 189) 
Em 1860 foi apresentado parecer de Comissão de Inquérito para estudar a problemática do meio circulante brasileiro e uma das principais conclusões é de culpa do excesso de emissões de notas do Banco do Brasil, as quedas no câmbio de 1857 e 1860, segundo BB (2010) "auxiliando o espírito de empresa e de especulação, foram além do que comportavam as condições em que nos achávamos.” (p. 36). Nessa direção, “a influencia governamental e a pressão dos interesses privados sobre o Banco concorreram para que se tomassem medidas artificiais e precárias (...)” (p. 36).

Comparadas com algumas experiências internacionais, Souza Franco (1848) bem coloca que:

No exame das relações dos bancos com o Estado cujos planos eles podem auxiliar, o contrariar, convém não perder de vista, que estas associações, e especialmente as que emitem bilhetes circulantes, tomam caráter público, e importância, que muitas vezes lhe exige direção, e sempre contraste. E a influência que adquirem no suprimento do mercado monetário, e os riscos de abusos, que em alguns países hão chegado a ser gravíssimos, tem chamado sobre sua organização a atenção dos Governos. (p. 65-68).

Nessa direção, Melo Franco (1947) destaca:

(...) que por mais que se pretendesse dar ao Banco a aparência de uma organização comercial autônoma, capaz de viver vida própria com seus recursos, pouco a pouco se foi tornando patente o seu caráter de dócil instrumento nas mãos do Estado, que dele se serviu cada vez mais livremente, até que a sua utilidade se diluiu na onda de descrédito, injustamente exagerada por uma demagogia parlamentar deslembrada dos serviços que o país devia a um instituto tão miseravelmente tratado. (p. 33).

O futuro ministro da Fazenda, em sua obra Os Bancos do Brasil, faz uma reflexão sobre as experiências francesas, inglesas e norte-americanas no tocante ao papel dos bancos emissores (“centrais") em meados do século XIX. Quando mencionado o caso francês, o autor afirma que a legislação era dura, restrita e severa aos bancos, com uso quase total da moeda metálica e o funcionamento quase que exclusivo em solo francófono do Banco da França e suas filiais (Souza Franco, 1848).

Na Grã-Bretanha, Souza Franco (1848) ensina que a legislação era mais livre, com plena liberdade de associação e emissão de bilhetes, exceto numa zona de 65 milhas 
em torno da Igreja de Saint Paul em Londres, "onde por privilégio do Banco da Inglaterra só era concedido por este.” (p. 66).

Em relação aos Estados Unidos, Souza Franco (1848) afirma que a especulação é desenfreada, com quase oito centenas de instituições financeiras, com "espantoso número de quebras". (p. 67). Como as legislações são distritais, cabem aos legisladores locais a determinação de regras e poucos deles à época tem trabalhado para tal fim.

Com a ascensão em 1857 de Bernardo de Souza Franco como ministro da Fazenda, este partidário da pluralidade de emissão, foram criados diversos bancos de emissão através de simples decretos executivos, sendo, inclusive, acusado de inconstitucionalidade. (BB, 2010). A reforma bancaria empreendida por Souza Franco foi duramente impactada pela crise de 1857-58, que também causaram perdas ao Banco do Brasil, que perdia sua maior vantagem, que era a exclusividade do poder de emissão. (BB, 2010).

Com a queda de Souza Franco em 1858, sobe como ministro Sales Torres-Homem que também fica apenas um ano no poder, sendo contrário as ideias anteriores de pluralidade emissora. Uma de suas propostas era que todos os bancos emissores deveriam realizar seus bilhetes em ouro à vontade do portador. Nesse projeto, o Banco do Brasil deveria resgatar anualmente 2.000:000\$000 de papel do governo. (BB, 2010).

Pacheco (1973) afirma que o Imperador era contrário às ideias de Souza Franco, “e que sua posição sempre predominava, quando ele passava da atitude de expectativa, em que muitas vezes como que hibernava (...) era claro (...) que significavam um passo decisivo para uma correção da política bancaria”. (p. 137).

BB (2010) estipula que "a questão bancaria transformou-se em uma devoradora de governos", com a queda de diversos ministros e presidentes da instituição, devido ao embate sobre a unidade/pluralidade de emissão. (p. 43).

O senador Angelo Muniz da Silva Ferraz assume como novo chefe do Gabinete em 1859 aumentando de maneira rigorosa o controle governamental nas instituições bancárias, com o decreto 2.457 de 5 de setembro de 1859 inclusive com envio de demonstrativos semanais sobre as operações. Além disso, empreendeu diversas ações para o controle direto do governo das sociedades anônimas, culminando com a Lei 
1083 de 22 de agosto de 1860. Demitiu-se em 1861, com Gabinete chefiado pelo Duque de Caxias, tendo como ministro da Fazenda, José Maria da Silva Paranhos. (BB, 2010).

O Banco do Brasil efetuou uma comissão para tratar diretamente da Lei de 1860 (BB, 2010), já que suas disposições não poderiam ser aplicadas ao Banco "sem grave ofensa de direitos adquiridos (...)" (p. 50).

Nesse certame, Pacheco (1973b) afirma que o Banco do Brasil era elemento central em todos os debates, alvo de ataques e defesas; porém "sua posição era de constante embaraço, não só porque nem sempre coibia excessos emissionistas, como porque não consegui sustentar (...) por vício de origem, a suficiência do seu fundo disponível (...)". (p. 199).

Mas segundo BB (2010):

$\mathrm{Na}$ verdade, ambas representavam o inconformismo dos acionistas do Banco, inclusive de seus diretores, ante o duro sistema de controle e exigência de conversibilidade que a lei da reforma bancária introduzira (...) A imprensa do Rio de Janeiro, em outubro de 1861, registrava que o estado de espírito dos acionistas do Banco do Brasil era de decepção e revolta, por entenderem que o seu capital não estava sendo devidamente remunerado. (p. 50)

Nesse cenário ganha novamente força a posição da unidade de emissão, com a negociação entre os bancos emissores do Rio de Janeiro. A Assembleia dos Acionistas do Banco do Brasil aprovam em 2 e 4 de abril de 1862 e o Parlamento através do decreto 2.970 de setembro do mesmo ano. Entraram, assim, novas disposições estatutárias com a elevação do capital do Banco do Brasil para 33.000:000\$000, além de um acerto de número de ações e compensações financeiras entre este e os demais bancos, o Banco Commercial e Agrícola e o Banco Rural e Hipotecário. (BB, 2010).

O ano de 1863 já trazia indícios do que seria a Grande Crise de 1864, com os problemas de liquidez da casa bancária A.J.A Souto \& Cia, que exigia auxílio imediato do Banco do Brasil na visão de sua diretoria. (BB, 2010). Porém, os fatos se agravaram e o tumulto já havia se instalado, com corrida bancaria a fim de trocar as notas bancárias por ouro em 13 de setembro de 1864: “o fundo metálico do Banco do 
Brasil estava ameaçado de se esgotar.” (p. 55). Foi novamente acionado o governo, com os anseios da diretoria em suspender todos os pagamentos na praça por 30 dias e exceder o seu limite de emissão novamente: foi atendido pelo Imperador, com permissão do triplo e suspensão de até 60 dias dos vencimentos dos títulos.

As consequências da crise: até março de 1865, falências e concordatas na corte no montante de aproximadamente 70.000:000\$000, queda do movimento comercial e imobiliário, decesso das ações das companhias e aumento ao quíntuplo da emissão do Banco do Brasil. (BB, 2010). Mas a causa mais comentada da crise foi novamente o abuso do fornecimento de crédito, mais notadamente aqueles efetuados em prol da Casa Souto, "que adotava procedimentos de operações e de contabilidade bastante peculiares e insólitos.” (p. 56).

Além desse cenário, havia a pressão do governo por recursos para cobrir a cara Guerra do Paraguai, no qual estávamos envolvidos. (BB, 2010).

As críticas começam a aumentar: temia-se quanto a sua estabilidade e solvência. (BB, 2010). Mas a situação era estranha, já que embora em grande crise institucional e conjuntural, "registrava lucros que canalizavam vantagens para os seus acionistas, o que era chocante numa época em que a guerra externa era sorvedouro insaciável de recursos, especialmente da preciosa e sempre escassa moeda metálica." (p. 58): "não teria sido inferior a 40.000:000\$000 a soma das importâncias que o Tesouro retirou de circulação para cobrir as despesas com a guerra (...)"(p. 60). Em muitas ocasiões, o governo já nem solicitava os recursos, apenas enviava ofícios exigindo as entregas ao Tesouro. (BB, 2010).

Com o Império em dúvida e sem ação diante de alarmante cenário, o senador Silveira da Mota apresentou um projeto de lei a fim de mudar a natureza do Banco do Brasil, com o intuito de auxiliar mais notadamente a lavoura, a nossa principal indústria. Foi aprovado com pouquíssimas alterações. (BB, 2010). Os principais pontos seriam o fim da emissão por parte do Banco do Brasil e a divisão do mesmo em duas repartições: a de hipotecas, com fundo de 35.000:000\$000 e a carteira agrícola, destinada quase exclusivamente às operações com cafeicultores da Corte e regiões adjacentes. (BB, 2010). Nesse cenário, o Governo comprou toda a reserva metálica do banco. 
Em 1867-1868 foram reorganizadas as Caixas Filiaes: as deficitárias da Bahia e Pernambuco estavam em processo de liquidação; foram mandadas liquidar as do Pará, Maranhão e Rio Grande do Sul, mantendo-se apenas as caixas de São Paulo e Ouro Preto. (BB, 2010).

Embora tenha ocorrido um afastamento da interferência do governo no Banco, com o ônus da emissão, outras intromissões ainda eram válidas, como o apontamento do presidente, o resgate do papel-moeda e os encargos do financiamento à guerra. (BB, 2010).

O fim dos anos 60 trouxeram consigo inúmeros pedidos de renegociações e liquidações e também uma mudança de direção completa do banco, com nova diretoria presidida por Militão Máximo de Sousa e a extinção da Filial de Ouro Preto, restando apenas a matriz na Corte e a agência de São Paulo. Também nessa fase volta a operar no financiamento com o governo ao comprar do Tesouro 20.000:000\$000 em apólices da dívida pública e posteriormente mais 18.300 contos de réis. (BB, 2010).

Inúmeras críticas foram levantadas, já que o foco da carteira era o empréstimo aos agricultores, não ao governo. A questão agrícola volta a tona: era mister aumentar volumes e prazos e diminuir a taxa de juros para tão importantes devedores. (BB, 2010)

Porém dessa nova proposta apenas a província do Rio e as duas adjacentes seriam atingidas, deixando de lado as outras 17.

Além disso era elitista, já que deixava de fora a pequena agricultura, restringindo para operações superiores a 10 contos. (BB, 2010): “o Banco, segundo as críticas, visava mais seus interesses do que as necessidades da lavoura, e agia no sentido de salvar seus devedores de uma liquidação que lhe pudesse ser desvantajosa.” (p. 73).

Assim, em 1873 foi sancionada a lei 2.400 de 17 de agosto que prorrogava a duração da instituição por mais de 14 anos e obrigava-o a empregar uma quantia nunca inferior a 25 mil contos em empréstimos à lavoura, fixando em $6 \%$ e 5\%, respectivamente, os juros e amortizações. (BB, 2010).

Em maio de 1875 a crise é deflagrada com a concordata dos Bancos Alemão, Nacional e a Casa Mauá, inclusive com corrida bancaria. (BB, 2010). 
Nesse mesmo ano, a repartição hipotecária da instituição, mais precisamente o seu fundo estava esgotado, necessitando, novamente dos auxílios do governo, já que estava despojado dos antigos poderes de emissão. (BB, 2010).

A promulgação do decreto legislativo n. 2.687 de 6 de novembro de 1875, apoiado na tese defendida na Câmara dos Deputados em julho - de que a agricultura era a principal, quase exclusiva criadora de riqueza, sendo "indispensável à proteção dos poderes públicos" (p. 76) - esquecia que a base de garantias naquele época ao financiamento rural era extremamente débil, vide o exemplo das próprias propriedades que não estavam precisamente demarcadas e a própria questão do escravo. (BB, 2010). Após a metade dos anos de 1870, o Império e seu representante maior começam a se abalar: "o longo reinado se tornou cansativo para o imperador e para a comunidade.” (p. 82). Nesse período ocorreu uma reaproximação do BB com o poder político, propondo medidas "que pareciam ser de conveniência entre o Banco e o governo." (p. 83). Essas medidas surtaram algum efeito, provocando, inclusive o aumento do já farto dividendo por ação de $9 \$ 000$ para $10 \$ 000$.

Porém o abalo mais sério se deu com o fim da escravidão nos anos de 80 , que provocou a perda de muitas garantias, já que o banco era detentor de inúmeras operações garantidas pelos recém-abolidos, além das próprias dificuldades trazidas com o encarecimento da produção, ao ter que procurar braços livres e, consequentemente, assalariados para desempenhar as atividades outrora executadas pelos libertos. (BB, 2010).

Nesse esteira, entra novamente o governo fornecendo funding para a instituição e para o Tesouro a fim de intensificar os empréstimos à nossa deficiente lavoura: esse fato se acentua nos últimos meses do Império, com a ascensão do Visconde de Ouro Preto à pasta da Fazenda, inclusive com a fundação de um banco de crédito real - o Banco Nacional do Brasil - de grande envergadura e com apoiado, também, em garantias governamentais. (BB, 2010).

Mesmo com a proclamação da República aos 15 de novembro de 1889, o Banco do Brasil e o Ministério da Fazenda, nesses primeiros anos, através de Rui Barbosa, seu ministro, continuaram a trabalhar arduamente com a intenção de salvar a agricultura, nossa principal riqueza. (BB, 2010). 
A atuação do Governo se torna direta, inclusive com as participações dos Bancos, assim como destacado mais acima por Netto (2009).

Esses primeiros anos da República tanto militar quanto a civil foram marcados pelos problemas sociais, como as Revoltas de Canudos e das Armadas, causando grande gastos para o governo e também pela incipiência da crise de superprodução do café assistida nas primeiras décadas do século XX, acompanhando da emissão de notas por parte das empresas: a febre especulativa. Nessa transição do poder político, o Banco do Brasil não passou ileso, pois vivia ainda os percalços da abolição da escravidão, em que via suas garantias perderem completamente valor e seus devedores encontrando muitas dificuldades no cumprimento de suas obrigações. Mas suas relações eram bem cordiais com o Ministro da Fazenda, oferecendo, inclusive, com a cessação da carteira hipotecária, auxílio ao crédito público. (BB, 2010).

Os anos de 90 assistem a uma série de transformações no Banco do Brasil. Em primeiro lugar, a venda da importante filial de São Paulo, operando exclusivamente no Rio de Janeiro. Em segundo, a rescisão da carteira hipotecária em 1891, que forçava sua liquidação junto ao Governo. Terceiro a transferência dos privilégios de emissão para o Banco da República dos Estados Unidos do Brasil. (BB, 2010).

Porém, importante fato é a nova fusão do Banco do Brasil, agora com o Banco da República dos Estados Unidos do Brasil, instituição agora denominada Banco da República do Brasil, com novamente o Governo elegendo presidente e vice (de nove membros da diretoria), com poder de veto, muito semelhante àquele de 1853 . De acordo com BB (2010), esse evento foi aprovado em 1893: "nasceria o novo banco, assim, solidamente amparado nos recursos do governo." (p. 97).

A crise é extremamente difícil nesses primeiros anos da República: a questão do papel-moeda se torna elemento central.

Mesmo nesse período, a diretoria estende aos agricultores os benefícios dos financiamentos através da emissão de bônus. As liquidações atingiam níveis alarmantes em 1895. A negociação da transferência das carteiras hipotecárias dos dois bancos fundidos também fora efetuada. Para isso, alguma decisão deveria ser dada à problemática da emissão das duas instituições, e defendido pelos seus diretores as mesmas passaram a ser encampadas pelo Tesouro. (BB, 2010). 
No governo de Prudente de Morais, ocorre uma nova reforma nos estatutos em decorrência dos pontos citados acima, porém a diretoria continua encabeçada pelo governo, que tem agora o poder de apontar o presidente em uma diretoria composta por mais quatro membros. $(\mathrm{BB}, 2010)$.

A crise chegou a seu extremo em 1897, com o câmbio na mínima e uma dívida alarmante notadamente com os ingleses, forçando, assim, uma negociação da dívida nacional. Segundo BB (2010), no ano de 1898, o banco se "libertava (...) das suas amarras com o governo", através da negociação e início do pagamento de suas dívidas para com o mesmo. Novamente o estatuto foi reformado e o banco passa "ao regime comum das sociedades anônimas, com diretores todos eleitos em Assembleia com um presidente e quatro membros, (...) deixavam de existir os diretores nomeados pelo governo. (p. 107).

Mas não levou muito e o Banco entrou em colapso muito em decorrência da descapitalização de 50.000:000\$000 pagos ao Tesouro e `a concorrência dos bancos estrangeiros, que vinham tendo à preferência dos brasileiros (BB, 2010).

Após muitas discussões e à beira de uma derrocada, o banco apelou socorro ao governo que foi negado. Como resultado das negociações, o banco passava à direção do governo em 1900, transferindo toda a administração e todo patrimônio social ao poder político: a nova administração seria composta por apenas dois diretores nomeados pelo Ministro da Fazenda. BB (2010) afirma que a interferência era tão poderosa que:

Durante esta gestão a rotina do Banco transcorreu em quase completa obscuridade. Não se divulgaram relatórios, nem balanços, não seu reuniu a Assembleia dos Acionistas, não se distribuíram dividendos e nem se lavraram atas de sessões dos órgãos dirigentes. Nem se cumpriu o mínimo dever de prestar contas aos acionistas e à opinião pública. (p. 109). 


\section{3 - AS PRINCIPAIS IDEIAS DE ANTONIO GRAMSCI}

Quando se fala em Teoria Crítica, não há como se desvincular do nome de Karl Marx (1818 - 1883), cuja obra permeia diversos campos do conhecimento, como filosofia, economia, sociologia e política. Aliás, ele é o cerne ou a inspiração para as tradições não explicitamente marxistas nesse paradigma. Nesse sentido, Marx acreditava que "a razão era não só um instrumento de apreensão da realidade mas, também da construção de uma sociedade mais justa, capaz de possibilitar a realização de todo o potencial de perfectibilidade existente no seres humanos." (Quintaneiro, Barbosa \& Oliveira, 2011, p. 27). Esse pensador influenciou de sobremaneira a obra de Antonio Gramsci.

Quando inseridos esses conceitos na obra de Gramsci (e mesmo na de Marx), conforme colocado por Portelli (1977) existe muita controvérsia acerca da relação e/ou primazia da estrutura em relação a superestrutura (ou vice-versa), mas segundo o mesmo esta é uma questão secundária: o ponto fundamental é o vínculo orgânico, em primeiro lugar e dialético, na sequência entre estrutura e superestrutura.

Já afirmava o autor (Portelli, 1977) que a análise da estrutura no bloco histórico não é muito abordada nos Cadernos, talvez muito ao fato da teoria marxista já ter consagrado tal abordagem. De modo clássico, Gramsci (1999) define estrutura com base nas forças materiais de produção. Além disso, há um caráter um tanto quanto estático da estrutura em relação à superestrutura no contexto do bloco histórico.

Gramsci (1999) destaca que a análise da estrutura só pode ser feita quando findo o período considerado: "a solução será, portanto, reportar-se ao passado; o passado representa as condições materiais objetivas, para as quais o presente é apenas a continuação, o desenvolvimento. A partir daí, passado e estrutura se identificam.” (p. 222). Assim sendo, Gramsci (1999) destaca que o estudo da estrutura do bloco histórico pode ser empreendido de três formas:

(a) um estudo imediatista, de caráter hipotético;

(b) o estudo tido como "perigoso" do passado que busque uma "justificação tendenciosa da superestrutura" e 
(c) a importância do bloco histórico e a importância da superestrutura, já que a análise de sua evolução permitirá o estudo indireto da própria estrutura.

Na visão de Portelli (1977), para a formação de um bloco histórico é fundamental que a superestrutura e a estrutura esteja organicamente ligados: na visão gramscista a organicidade pode ser entendida como "a necessidade do movimento superestrutural do bloco histórico evoluir nos limites do desenvolvimento da estrutura, mas também, mais concretamente, como a obra dos grupos sociais encarregados de gerir as atividades superestruturais". (p. 47).

Para o autor esse vínculo orgânico é uma organização social bem concreta, já na própria influência da estrutura sobre a evolução da superestrutura. Dessa forma, Portelli (1977) afirma que:

Gramsci estuda as características essenciais de todo movimento superestrutural orgânico, sublinhando dois aspectos:

- Qualquer ato ou ideologia orgânico deve ser 'necessário' à grupos sociais e dirigi-los de acordo com as condições socioeconômicas.: enquanto historicamente necessárias, têm elas uma validade psicológica; organizam as massas humanas, forma o terreno onde os homens se movem, adquirem consciência de sua posição, lutam etc;

- Devido a isso, e este é o segundo aspecto, os movimentos superestruturais orgânicos adquirem caráter permanente. Representam a ideologia, a política dos diversos grupos sociais e, nesse sentido, dão lugar à crítica histórica-social, que se dirige aos vastos agrupamentos, mais além das pessoas diretamente responsáveis, mais além do pessoal dirigente. Apenas na medida em que os movimentos superestruturais respondam a essas condições orgânicas, serão o 'reflexo' da estrutura e formarão com ela um bloco histórico. (p. 48).

Porém, resta uma pergunta: como se traduz de maneira concreta esse vínculo orgânico?

Gramsci (1999) afirma que esse movimento é assegurado pela "camada social encarregada de gerir a superestrutura do bloco histórico - os intelectuais." (p. 1518). Dessa maneira, eles podem ser entendidos como funcionários da superestrutura em nome da classe que representam e à qual estão estreitamente vinculados, social e economicamente (ao grupo dominante). O vínculo orgânico entre estrutura e 
superestrutura mostra-se, pois, de maneira bem concreta e não somente teórica. Mas relembra o autor que há certos limites nessa organicidade, existindo alguns tipos de movimentos superestruturais que não são orgânicos, tais como os:

(i) conjunturais, que se diferem quanto à duração e o alcance histórico;

(ii) erros políticos dos representantes da classe dirigente, que o próprio desenvolvimento histórico através de suas crises corrige e supera;

(iii) atos para alinhamento e reorganização interna da superestrutura e do pessoal intelectual e;

(iv) ideologias arbitrárias, que são apenas a negação das ideologias orgânicas.

Portelli (1977) destaca Bobbio em sua interpretação sobre Gramsci quando afirma que o sardo "atribui um papel determinante e mesmo a primazia à superestrutura do bloco histórico, enquanto a estrutura é considerada o elemento essencial na teoria marxista clássica.” (p. 52), Porém essa visão é criticada, já que afirmar a primazia do primeiro, “não seria inverter o esquema marxista?" (p. 52)

Gramsci distingue, pois, as relações estrutura-superestrutura em vários graus, segundo a análise de Portelli (1977):

(i) O mais primitivo é aquele em que a correlação de forças está estritamente vinculada à estrutura e em que as superestruturas são um prolongamento direto desta;

(ii) Em um segundo nível situa-se a correlação de forças políticas, que Gramsci define como 'a avaliação do grau do homogeneidade, autoconsciência e organização atingido pelos diferentes grupos sociais. (p. 53)

Nesse ponto, Bianchi (2008) aponta que a relação entre estrutura e superestrutura na visão gramscista adquire um “nexo necessário e vital.” (p. 137).

Portelli (1977) quando analisa as diversas interpretações dos autores afirma que na de Bobbio, a primazia da superestrutura ocorre já que "o momento ético-político domina o momento econômico através do reconhecimento de que o sujeito ativo da história faz da objetividade reconhecimento que permite transformar as condições materiais em instrumento de ação e assim atingir o objetivo almejado.” (p. 54). Já a 
interpretação ortodoxa e resposta a Bobbio são dadas por J. Texier e L. Gruppi, que consideram que para Gramsci, “a estrutura socioeconômica do bloco histórico permanece o momento determinante ao qual é necessário se referir, ainda que em ‘última análise' (p. 55).

No ponto de vista de Portelli (1977), as visões que atribuem primazia ou a estrutura ou a superestrutura se referem mais ao entendimento de Marx do que de Gramsci propriamente: para o primeiro há uma primazia à estrutura econômica, que desempenha o papel principal, sendo o 'palco de toda a história', enquanto a superestrutura política lhe é subordinada e a superestrutura ideológica subordinada a essa última; já Gramsci "não analisa essa relação no seio do bloco histórico como uma relação entre dois elementos de importância desigual, e nisso difere de Marx: a superestrutura ético-política tem um papel de importância igual ao de sua base econômica, e não primordial (...)” (p. 55-56)

Vejamos a interessante visão levantada por Bianchi (2008) sobre a questão da revolução social, em que apoiado no Prefácio de 1859 à Contribuição para a Crítica da Economia Política afirma que "a crueza dessas formulas facilitou a apropriação dogmática por parte do nascente movimento socialista e sua consolidação em uma versão economicista e evolucionista, que tinha entre seus autores expoentes da Segunda Internacional.” (p. 125)

Para Gramsci (1999), o “tempo da estrutura é lento” (p. 1443), sendo que no passar da história e no seu desenvolvimento, o conjunto de forças materiais de produção é o elemento que menos varia, podendo ser determinado e medido com exatidão.

Portelli (1977) reforça que essa relação é:

(...) dialética entre dois momentos igualmente determinantes: o momento estrutural, pois ele é a base que engedra diretamente a superestrutura, que no início é apenas o seu reflexo; durante o período considerado, a superestrutura só poderá desenvolver-se e agir entre limites estruturais bem precisos: assim, a estrutura influi, constantemente sobre a atividade superestrutural. $\mathrm{O}$ momento éticopolítico desempenha de qualquer modo, em função dessa base, um papel motor. É ele que desenvolve a consciência de classe dos grupos sociais, que os organiza política e ideologicamente (...). (p. 56) 
Nessa direção, Gramsci buscava reservar a expressão ideologia em seu sentido forte para designar 'a superestrutura necessária de uma determinada estrutura. Pode-se, pois, segundo o Gramsci (1999) pensar em uma "teoria materialista das ideologias na qual as forças materiais são o conteúdo e as ideologias a forma, sendo essa distinção entre forma e conteúdo seriam uma distinção metodológica e não orgânica, porque as forças materiais não seriam concebíveis historicamente sem forma e as ideologias seria fantasias individuais, sem as forças materiais. Assim, as ideologias são fatos históricos reais e concretos que devem ser revelados e combatidos "em sua natureza de instrumentos de domínio":

(...) Como das estruturas nasce o movimento histórico? E entretanto esse é o ponto crucial de toda a questão do materialismo histórico, é o problema da unidade entre a sociedade e a "natureza". As duas proposições: -1) a "sociedade" não se coloca problemas para cuja solução não tenham se dado as condições (premissas) necessárias e suficientes; 2) nenhuma forma de sociedade desaparece antes de ter esgotado todas as possibilidades de desenvolvimento - deveriam ter sido analisadas em todas suas possibilidades e consequências. Apenas nesse terreno é possível eliminar todo o mecanicismo e todo o traço de "milagre" supersticioso. Também nesse terreno deve ser colocado o problema da formação dos grupos políticos ativos e, em última análise, o problema das grandes personalidades da história. (p. 869)

Segundo Portelli (1977) o principal conceito na obra de Gramsci é de Bloco Histórico, já que dele são derivados ou analisados todos os demais conceitos.

Bem afirma Bianchi (2008) que a definição desse termo tinha uma "relação dialéticomaterial com a realidade, assumindo-se como unidade dialética entre forças produtivas, relações sociais de produção e superestrutura jurídico-política num dado momento histórico": unidade entre natureza e o espírito (estrutura e superestrutura). Dessa forma, o conceito de bloco histórico era visto como uma "ferramenta crítica com vistas a interpretação das relações histórica (...) existentes entre estrutura e superestrutura, condições objetivas e subjetivas, forcas materiais de produção e ideologias." (p. 137).

Para a função de propagadores de um dado sistema hegemônico, em Gramsci (1999) os intelectuais das classes dominantes, vistos como progressistas atraem e dão por 
cabo subordinando os demais intelectuais dos outros grupos, gerando, dessa forma, "um sistema de solidariedade entre todos os intelectuais, com laços de ordem psicológica (vaidade, etc.) e, frequentemente de casta (técnico-jurídico, corporativo, etc.) (...) leva à criação de um bloco ideológico (...) que vincula as camadas de intelectuais aos representantes de classe dirigente." (p. 104). Outrossim afirma que não basta o a condição econômica, é necessário que o grupo dominante tenha uma política para os intelectuais, quer através de (i) uma concepção de vida, uma dignidade intelectual ou (ii) do programa escolar, educativo, pedagógico.

Como consequência dessa abordagem, observa-se a anulação das tentativas de sobrevivência dos grupos rivais e da antiga classe dirigente.” Portelli (1977) afirma:

O bloco ideológico é fator de hegemonia sob um duplo aspecto, num sistema realmente hegemônico: por um lado em seu próprio seio, na medida em que os representantes da classe dirigente orientem os outros grupos sociais e sobretudo, por outro lado, a nível do bloco histórico, permitindo à classe dirigente controlar por intermédio do bloco ideológico, outras camadas sociais. (p. 67)

O controle dos outros setores visa diminuir o peso da sociedade política e, consequentemente, da coerção; como exemplos, Gramsci (1999) cita o fenômeno da opinião pública, em que a classe dirigente utilizando a sociedade civil para um resultado político determinado e a divisão dos poderes, tal como o Parlamento.

Outro fenômeno tratado pelo cárcere é o do transformismo, que consiste na agregação dos intelectuais das classes subalternas à classe política, para decapitar a direção desses grupo. (Gramsci, 1999). A ferramenta mais eficaz para esse fim é a absorção ideológica, capaz de conformar as novas forças aos interesses vitais do grupo dominante.” (p. 633). O objetivo é simples, a perpetuação da dominação, impedindo de maneira acintosa a formação de elites intelectuais dos demais grupos. Nesse sentido o movimento sociopolítico relevante ao transformismo é o de revolução passiva, isto é, aquela não-jacobina, de dois tipos, a primeira sem participação das massas, tal qual no Risorgimento Italiano e a segunda com o impedimento de progresso dissimulado de classes sociais que avançam.

Porém bem afirma Portelli (1977): 
Gramsci mostra, pois, que se a hegemonia de uma classe fundamental é a base da edificação do bloco histórico, um bloco histórico localmente determinado pode ser a base da hegemonia dessa classe: a formação do bloco histórico italiano sob a dominação da burguesia foi facilitada pela força hegemônica da burguesia sobre toda a Europa na mesma época, e pela prévia formação de um bloco histórico local estreitamente dirigido pela burguesia, no Piemonte. (p. 76)

A interpretação de Gramsci acerca do tema hegemonia contém três grupos sociais diversos no contexto do bloco histórico na visão de Portelli (1977).:

(a) a classe fundamental: que dirige o sistema hegemônico;

(b) os grupos auxiliares, que servem de base social à hegemonia e de "viveiro para seu pessoal";

(c) as classes subalternas, isto é, os excluídos do sistema hegemônico.

Todavia, Nogueira (2003) lembra que o conceito gramsciano é "empregado basicamente para caracterizar a capacidade que um grupo tem de dirigir eticamente e estabelecer um novo campo de liderança" (p. 185): deve-se evitar a aproximação do uso de Gramsci, com seu uso coloquial, de raízes militares, como força, como imposição.

Quando falamos sobre os intelectuais, Portelli (1977) afirma que o estudo dos papéis dos intelectuais apresenta três aspectos no contexto do bloco histórico, a saber:

(a) o vínculo orgânico entre o intelectual e o grupo que ele representa e sua função no seio da superestrutura;

(b) as relações entre os intelectuais do bloco histórico e os do antigo sistema hegemônico;

(c) a organização interna do bloco intelectual no seio do bloco histórico.

Em relação ao ponto (a), Gramsci afirma que há diferentes categorias de intelectuais, porém um traço comum é o seu vinculo mais ou menos estreito a uma determinada classe social. Para o autor o vínculo orgânico entre a estrutura e a superestrutura é refletida na função dos intelectuais, sendo encarregada de elaborar e gerir a superestrutura que dará a essa classe (dominante) homogeneidade e direção do bloco 
histórico. Evidencia-se, assim, o caráter dialético do vínculo orgânico. (Portelli, 1977).

Mas deve ficar claro que os intelectuais não são uma classe, mas grupos contidos nessas. Contudo, afirma Portelli (1977):

(...) as camadas mais importantes e complexas constituem-se a partir das classes fundamentais no domínio econômico (...) tal situação não se produz (...) no caso das classes subalternas, que são obrigadas a importar seus intelectuais, e particularmente os grandes intelectuais. Isso explica a grande vulnerabilidade dessas classes: a consciência de classe de seus intelectuais pode ser menos elevada e os dirigentes das classes dominantes tentarão permanentemente integrar esses intelectuais à classe política, particularmente através do recurso ao transformismo. (p. 85)

Assim, a principal função do intelectual é de ser um (Portelli, 1977):

(...) emissário do grupo dominante para o exercício das funções subalternas de hegemonia social e do governo político (...) Gramsci (os) qualifica como funcionários das superestruturas (...) os intelectuais são células vivas da sociedade civil e da sociedade política: são eles que elaboram a ideologia da classe dominante, dando-lhes assim consciência de seu papel, e a transforma em concepção de mundo, que impregna todo o corpo social. No nível da difusão da ideologia, os intelectuais são os encarregados de animar e gerir a estrutura ideológica da classe dominante no seio das organizações da sociedade civil (Igrejas, sistema escolar, sindicatos, partidos, etc) e de seu material de difusão (mass media). Funcionários da sociedade civil, os intelectuais são igualmente os agentes da sociedade política, encarregados da gestão do aparelho do Estado e da força armada (homens políticos, funcionários, exército, etc.) (...) somente após a criação de uma camada de intelectuais que exerça a hegemonia e a coerção uma classe adquire, realmente, sua homogeneidade. (p. 87).

Porém mesmo representando, como função, o intelectual tem uma certa autonomia em relação à estrutura socioeconômica, em primeiro lugar como resultado da origem social destes, já que a grande massa provém de classes ligadas ao poder dominante, a classe dirigente (Gramsci, 1999). O mesmo autor afirma que essa autonomia pode levar a uma crise orgânica, quando uma classe não é tida mais como fundamental. 
Já em relação ao segundo item (b) Gramsci (1999) afirma que nas sociedades que tomaram um rumo capitalista foi criado um novo tipo de intelectual, aquele ligado ao quadro técnico, o especialista da ciência aplicada. Adicionalmente, o sardo categoriza dois tipos de intelectuais: aqueles tidos como orgânicos, isto é, da nova classe fundamental e os tradicionais, aqueles do sistema hegemônico anterior: para exercer a hegemonia, a classe fundamental deve ou aniquilar ou absorver os intelectuais tradicionais.

Porém, Portelli (1977) afirma que "o fato de que os intelectuais se afirmarem ao mesmo tempo como novos e autônomos mostra que realmente são intelectuais do antigo sistema hegemônico que continuam dirigindo a sociedade civil e tentam manter-se assumindo a direção ideológica da nova classe fundamental.” (p. 94). O autor continua:

A atração exercida pelos intelectuais orgânicos sobre os intelectuais tradicionais leva, seja à adesão destes, com a manutenção de sua organização, seja a uma fusão, no próprio seio da organização superestrutural. Nesse último caso, os órgãos onde se realiza essa fusão são o aparelho de Estado, na esfera da sociedade política, e os partidos, na esfera da sociedade civil. (p 94).

Já no tocante ao item (c) afirma Portelli (1977), os intelectuais podem ser categorizados ou hierarquizados sob dois prismas na visão gramscista: a primeira, qualitativa, quando se considera apenas a superestrutura e a segunda, às relações, quando tomado o bloco histórico como um todo.

Inicialmente devem ser excluídos os agentes subalternos, que no bojo da superestrutura não desempenham função de direção, mas sim empregos de caráter instrumental e manual, de pura execução e não de iniciativa (Gramsci, 1999). Após esse corte, tem-se dois grupos: o dos grandes intelectuais, que são os criadores da concepção de mundo nos mais diversos campos do saber e o escalão inferior, aqueles que tem a função de administrar ou divulgar a ideologia: para Portelli (1977) "na luta ideológica contra os intelectuais do grupo dominante, de dirigir o essencial do esforço para os grandes intelectuais, chaves-mestras da criação ideológica.” (p. 97). Contudo, continua o autor, "não se deve concluir da importância do papel dos grandes 
intelectuais uma subestimação da parte de Gramsci do papel dos intelectuais subalternos (...) (p. 98).

No tocante às relações, os intelectuais também controlam o camponês, sendo seu modelo social, desviando-o, dessa maneira, do projeto de revolução. Afirma Gramsci (1999) que "o camponês sempre pensa que pelo menos um de seus filhos poderia vir a ser um intelectual (especialmente um padre), isto é, tornar-se um senhor, elevando o nível da família e facilitando sua vida econômica pelos contatos que ele não deixará de ter com os outros senhores." (p. 11).

Assim, Portelli (1977) elucida que o intelectual rural, do campo não é intelectual orgânico do campesinato, mas sim da classe dominante. (p. 100).

Além disso, Portelli (1977) também aponta outra função dos grandes intelectuais é a de desarmar ou coibir qualquer tentativa de ruptura da ideologia em benefício das classes subalternas, isolando seus intelectuais e, ao mesmo tempo, inserindo-os no sistema cultural "desligado do contexto social" da classe dominante. (p. 101). A "concepção de mundo", como referido por Gramsci, era voltada e incentivada estritamente com ambições ao lucro, como algo normal e natural, em cooptação da dinâmica estrutural no tocante à vida das pessoas como um todo.

Portelli (1977) elucida que Gramsci afirma frequentemente nos Cadernos o conceito de sociedade civil, de influência de Hegel e Marx, que retoma a direção intelectual e moral de um sistema social: como um complexo da superestrutura ideológica. Assim, Gramsci (1999) afirma que a sociedade civil é concebida como "o conjunto de organismos, vulgarmente ditos privados que correspondem à função de hegemonia que o grupo dominante exerce em toda a sociedade.” (p. 9).

A confusão aqui também deve ser evitada com o uso coloquial da palavra, já que como colocado Nogueira (2003) é um termo extremamente complexo, que envolve tanto um conceito per si como um projeto político "abrangente e igualmente sofisticado, com o qual se pode transformar a realidade." (p. 186).

Como bem afirma Portelli (1977), seu campo é muito extenso, sendo considerada também em três aspectos complementares:

(i) como ideologia da classe dirigente, abrangendo todos os ramos da ideologia, em áreas como artes, ciências, economia, direito, etc; 
(ii) como concepção de mundo, que é difundida de maneira ampla nas mais diversas camadas sociais para liga-las às classes dirigentes: assim ela se impregna e se adapta a todos os grupos e

(iii) como se trata da direção de cunho ideológico da sociedade, se exprime sob três faces: (a) com as organizações que criam e difundem a estrutura ideológica (grifo nosso) e (b) com os instrumentos de difusão ideológicos, ou seja, o material ideológico (grifo nosso), como o sistema escolar, a mídia de massa, as bibliotecas e porque não as informações emanadas das demonstrações contábeis (inclusão nossa).

"Uma concepção de mundo que se manifesta implicitamente na arte, no direito, na atividade econômica, em todas as manifestações da vida individual e coletiva.": é assim que Gramsci (1999) define o conceito-chave, ideologia. (p. 868). O autor afirma que só são essenciais as ideologias tidas como orgânicas, aquelas que são vinculadas a uma classe fundamental: a ideologia vai se difundir e se propagar na medida que se desenvolve a hegemonia sobre todas as atividades do grupo dirigente, criando diversas camadas de intelectuais (Portelli, 1997):

(..) que se especializam em um aspecto da ideologia desse grupo: a economia, as ciências, (...) Os diferentes ramos da ideologia qualquer que seja sua aparente independência, constituem as diversas partes do mesmo todo: a concepção de mundo da classe fundamental. (p. 23)

O autor aponta que as consequências dessa concepção tão ampla da ideologia é que estão contidas nessa todas as atividades do grupo dirigente, mesmo as que parecem ser menos ideológicas (Gramsci, 1999).

Porém a expansão não poderia aparecer como a realização dos interesses dos grupos diretamente beneficiados, devendo se aparentar como uma expansão universal como se fosse expressão de toda a sociedade. (Gramsci, 1999).

Nessa direção, essa concepção da classe dirigente, isto é, a ideologia deve se espalhar para toda a sociedade: para isso a filosofia e história se identificam nesse momento: qualquer filosofia histórica, isto é, orgânica deve prolongar-se através do senso 
comum, que, segundo Portelli (1977), é garantido pela "política, que assim assegura a unidade ideológica do bloco histórico.” (p. 25).

Bianchi (2008) bem afirma que "o desenvolvimento da economia e da política encontram intimamente vinculados e marcados por influências, ações e reações recíprocas, pelas lutas que protagonizam as classes em presença e suas formas superestruturais no terreno nacional e internacional.” (p. 175).

O senso comum se revela então como uma mistura de ideologias tradicionais, notadamente a religião e da ideologia dominante, através do bom senso. (Gramsci, 1999). O autor elucida que o senso comum seria o "folclore da filosofia", se situando no meio termo entre a filosofia e o folclore, esse que está no nível mais baixo do bloco ideológico, sendo uma concepção de mundo primitiva e incoerente.

A articulação da sociedade civil se dá de maneira muito complexa, ou seja, como a classe dirigente se organiza para difundir sua ideologia: essa organização se dá através da estrutura ideológica, entendida como a organização material para manter, defender e desenvolver a frente teórica, influenciando a chamada opinião pública. (Gramsci, 1999).

Bianchi (2008) afirma baseando-se nas ideias de Norberto Nobbio (1975), grande estudiosos de Gramsci, que a sociedade civil pode ser depreendida como "um conjunto de organismos vulgarmente chamados de "privados." (p. 179).

Contudo, afirma Nogueira (2003) a sociedade civil não deve ser encarada apenas como um território de ações e iniciativas privadas, mas deve ser observada com uma função estatal, dado que é colocada como hegemonia política e cultural de um dos grupos perante a sociedade como um todo.

Nessa estrutura existem as organizações que são encarregadas da propagação ideológica: a Igreja, a organização escolar sob o controle do Estado ou de grupos privados, a imprensa e a edição. Já em relação aos meios de comunicação há diversas formas de propagar, como os meios audiovisuais, livros, revistas (Gramsci, 1999).

Como bem destacado por Bianchi (2008), "a função desses organismos é articular o consenso das grandes massas e sua adesão à orientação social impressa pelos grupos dominantes." (p. 179). 
No tocante à sociedade política, Portelli (1977) afirma que nos Cadernos esse conceito foi pouco estudado, mas há várias referencias ao termo:

(i) sociedade política ou Estado, que corresponde à (função de) dominação direta ou de comando que se exprime no Estado ou governo jurídico;

(ii) sociedade política ou ditadura, ou aparelho coercitivo para conformar as massas populares ao tipo de produção e economia de um determinado momento;

(iii) governo político (...) aparelho coercitivo do Estado, que assegura legalmente a disciplina desses grupos que recusam seu acordo (...).

Essencialmente, agrupa o conjunto das atividades da superestrutura vinculadas à coerção, não se limitando ao domínio militar, mas se estendendo ao domínio do governo jurídico, o símbolo da força legal. (Gramsci, 1999).

A função de coerção é administrada por um tipo bem específico de intelectual, os burocratas, tornando esse fenômeno inclusive casta. (Gramsci, 1999).

Nesse sentido, Gramsci (1999) afirma que “(...) o Estado não é concebível mais que como forma concreta de um determinado mundo econômico, de um determinado sistema de produção" (p. 132), dessa maneira, o Estado é a expressão da organização social da produção no terreno das superestruturas.

Quando estudamos as relações entre sociedade civil e sociedade política, Gramsci (1999) afirma que não existe sistema social em que o consentimento seja a base exclusiva da hegemonia, nem Estado que possa, somente por meio da coerção, continuar a manter de forma durável sua coerção; assim, a sociedade civil e a sociedade política mantêm, pois, relações permanentes, através da colaboração dos órgãos das duas sociedades no seio do Estado, como a formação da opinião pública que favorece o consenso em todos os atos da sociedade política, através da imprensa, radio, etc.

Portelli (1977) afirma que esse vínculo é tão estreito, que se torna orgânico, no momento que o "Estado - strictu sensu - apodera-se diretamente, sem o intermédio de organismos privados, dos meios de modelar a opinião pública.” (p. 33).

O próprio Parlamento mostra essa relação, com sua forma ambivalente, órgão elaborador de leis da sociedade política e tradutor da opinião da sociedade civil: o exercício da hegemonia se caracteriza, então pela combinação entre força e consenso. 
Nesse sentido, Gramsci efetua uma ampliação do conceito de Estado, que seria entendido como um conjunto de organizações através dos quais é exercida a influência do grupo dominante. (Gramsci, 1999).

Gramsci define Estado em várias partes dos Cadernos, conforme apontado por Portelli (1977):

(i) Estado, isto é, sociedade civil mais sociedade política, hegemonia encouraçada de coerção;

(ii) Estado, em seu significado integral: ditadura mais hegemonia;

(iii) O Estado define-se, pois, por três características: (a) reúne a superestrutura do bloco histórico, tanto intelectual e moral quanto política, (b) equilíbrio entre esses elementos e (c) sobretudo, a unidade do Estado decorre de sua gestão por um grupo social que assegura a homogeneidade do bloco histórico: os intelectuais.

Nessa direção, Portelli (1977) aponta a importância relativa da sociedade civil na sociedade política, sendo de nível capital, já que para que a hegemonia se estabeleça de maneira robusta é preciso que estas sejam "igualmente desenvolvidas e organicamente vinculadas" para que a classe dominante possa "harmoniosamente perpetuar sua dominação”. (p. 37).

Assim, a hegemonia da burguesia se dá na impregnação ideológica de todo o sistema social.

Para Gramsci (1999), a primazia da sociedade civil só aparece com o fim do Estado e a sociedade sem classes. Esse novo sistema hegemônico, composto pela classe operária é capaz de resolver a distinção entre sociedade política e civil, fundamentalmente devido ao fato de ter que se unir a elementos da sociedade política (insatisfeitos) para a derrubada do poder dominante.

O Estado, nessa maneira, deve criar os mais novos e altos padrões para a civilização, adaptando-a, principalmente através da fusão dos intelectuais das duas sociedades no seio do Estado, sendo apenas uma etapa para a chamada "sociedade regulada", ou seja, sociedade sem classes. Logo, conclui o sardo que somente o grupo social que coloca o fim do Estado e de si mesmo pode criar um Estado-ético tendente a por fim às divisões internas dos dominados e a criar um organismo social unitário técnicomoral. (Gramsci, 1999). 
Na transição de um regime político, há a divisão desse último nível em várias etapas, culminando no que Gramsci (1999) chama de 'catarse', período no:

(...) qual as ideologias que germinaram anteriormente tornamse partido, confrontam-se e entram em luta, até que uma única, ou ao menos uma só combinação entre elas, tende a prevalecer, imporse, difundir-se por toda a área social, determinando, mais além da unicidade dos fins econômicos e políticos, a unidade intelectual e moral, colocando todas as questões em torno das quais a luta se desenvolve não em plano corporativo, mas em plano 'universal', criando assim a hegemonia de um grupo social fundamental sobre uma série de grupos subordinados. (p. 45).

Conclui-se, então que a catarse é o momento em que as ideologias de reflexo passivo da estrutura tornam-se parte integrante da superestrutura. (Gramsci, 1999).

Bianchi (2008) afirma que nesse fenômeno catártico:

(...) a estrutura deixaria de ser uma força exterior capaz de esmagar os indivíduos e condená-los a uma situação de passividade, e passaria a ser condição da liberdade desses homens, um meio para a criação de novas formas ético-políticas por meio da elaboração superior da estrutura em superestrutura. A determinação desse momento catártico era, assim, ponto crucial da filosofia da práxis, na medida em que esse momento coincidiria com o próprio movimento histórico. (p. 136).

Surpreendentemente, segundo Bianchi (2008) Gramsci foi apresentado ao público italiano como um teórico da cultura, mas o seu pensamento deveria ser mais lembrado por outra vertente, a política: “Gramsci parece ter identificado a necessidade de uma reflexão mais sistemática sobre a atividade política e aquilo que denominava de "ciência política" ou "ciência da política". (p. 143). Nessa reflexão, o diálogo com Maquiavel ocupava uma posição estratégica. Nesse cenário, Gramsci analisou Maquiavel e sua obra $O$ Príncipe sob duas vertentes:

(a) uma pesquisa sobre a interpretação marxista da obra de Maquiavel e

(b) a tradução para o marxismo de alguns conceitos. 
Afirma Bianchi (2008) que Gramsci fez uma aproximação do florentino com Marx no âmbito de uma filosofia da práxis, sendo esse o primeiro representante dessa vertente: “é por isso que nas notas intituladas Marx e Machiavelli ambos os autores não apareciam opostos um ao outro, nem como complementares, e sim como autores que partilhavam um mesmo lugar.” (p. 144)

Segundo palavras de Gramsci (1999) no Caderno 4: Dupla interpretação de Maquiavel: "por parte dos homens de Estado tirânicos que desejam conservar e aumentar sua dominação e por parte daquelas tendências liberais que querem modificar as formas do governos." (p. 425).

A caracterização maquiaveliana acerca da natureza humana (fixa e imutável) deveria ser rejeitada: isso permitiria conceber uma ciência política que em seu conteúdo concreto se identificaria com ciência histórica. A politica assim como pensada por Maquiavel era uma prática que se afirma em um tempo circular no qual a regularidade da natureza humana garantiria a constância dos ciclos históricos; para esse fim o estudo do passado é fundamental. Para Bianchi (2008), Gramsci negava essa característica de Maquiavel e a "afirmação de uma 'autonomia da política' implicava o reconhecimento de que a política não poderia ser reduzia à religião ou à ética": antes disso a arte, a moral e a filosofia "servem" a política . (p. 148-149).

Para Gramsci (1999), no Caderno 8 a "atividade política é, justamente, o primeiro momento ou o primeiro grau das superestruturas, é o momento no qual todas as superestruturas encontram-se ainda na fase imediata de mera afirmação voluntária, distinta e elementar." (p. 977). E ao recusar "o projeto intelectual de construir de modo idealizado um modelo de Estado, e ao assumir como objeto a ação política imediata, Bianchi (2008) elucida que o secretário florentino estava, também, recusando todo traço de idealismo metafísico. Seu pensamento político era, desse modo, materialista e histórico.

Para Bianchi (2008) “o interesse que Gramsci manifestou nos Quaderni del carcere pela obra de Maquiavel deve ser interpretado como constitutivo de um desenvolvimento crítico e uma nova problematização do tema vontade.” (p. 153). Assim, o caráter fundamental estava na junção da ciência política e da ideologia política na forma dramática do mito, que "teriam a capacidade a capacidade de, ao 
mesmo tempo, despertar a esperança e a mobilização necessária para a ação.” (p. $155)$.

Na visão de Gramsci (1999), a política pode ser dividida em a grande política e a pequena política, essa que tem "por objetivo a transformação ou conservação das relações de produção", daquela, que era tida como a "política do dia-a-dia, política parlamentar, de corredor, de intriga." Isso é o equivalente a superar a conjuntura da situação (p. 1563).

Para Portelli (1977) "a noção de hegemonia não era praticamente utilizada na literatura marxista." (p. 61). A origem desse conceito está mais ligado à Lenin (que nunca utilizou-o de forma literal), que segundo palavras do próprio Gramsci seria o mais importante desenvolvimento do marxismo, já que essa definição reavalia as concepções mecanicistas e fatalistas do economicismo.

Já a análise de Gruppi (1978) quanto a aproximação do sardo a Lenin é focada em quatro pontos principais:

(a) Base da classe da hegemonia: esse é tido como o mais importante aspecto na análise de Gruppi, já que para Lenin a ditadura tanto da burguesia quanto do proletariado se caracterizam pela uso da violência, pela coerção: já para Gramsci esses fatores são relevantes, mas sua análise não se limita a isso, dando valor a direção cultural e ideológica, completando a análise lenilista; o sardo afirma que “(...) se a hegemonia é ético-política, não pode deixar de ser também econômica, de ter seu fundamento na função decisiva que o grupo dirigente exerce no núcleo essencial da atividade econômica": nesse sentido, o Estado não é visto apenas como a sociedade política, mas a combinação deste com a sociedade civil.” (p. 62).

(b) Organização intelectual da hegemonia: esse é um ponto de confluência entre Gramsci e Lenin, apenas destacando que aquele versa mais sobre seu aspecto educativo.

(c) Grupos aliados: esse é um fator de destaque na análise da hegemonia, que corresponde "na necessidade da classe fundamental apoiar-se em grupos aliados."

(d) Correlação de forças no seio do sistema hegemônico: muito em decorrência do ponto anterior, deve existir uma correlação de forças na gestão e gestação do sistema hegemônico. 
Assim sendo, na visão de Gruppi, Lenin foca no aspecto político da questão hegemônica, sendo a missão-fim a derrubada pelo uso da força do aparelho Estatal; a sociedade política é o objetivo e, para atingi-lo, uma prévia hegemonia política é necessária. Já em Gramsci, o ambiente principal de luta é na sociedade civil, sendo que a conquista da sociedade política coroa essa hegemonia, completa Portelli (1977). Porém, Portelli (1977) ensina que quando ocorre seu “esboroamento e a utilização da força" são gerado sinais da "debilitação da hegemonia e da passagem à ditadura." (p. 67). Ditadura ou dominação são utilizados como definição de um grupo social não hegemônico, que domina a sociedade exclusivamente através da coerção, sendo para Gramsci, um período transitório entre dois períodos hegemônicos (Gramsci, 1999).

A seguir, analisaremos o financial reporting do Banco do Brasil buscando as construções ideológicas contidas nesse discurso (Capítulo 3) e os fins materiais para qual tal discurso era empenhado (Capítulo 4). 


\section{CAPÍTULO 3 - FINANCIAL REPORTING COMO INSTRUMENTO DE DISSEMINAÇÃO IDEOLÓGICA: ELEMENTOS DO DISCURSO}

Como comentado na Introdução, para atingir seus objetivos, a nossa análise está estruturada em duas vertentes:

(i) Questões específicas de discurso empregado (Partes 3.1 e 3.2)

(ii) Assuntos conceituais específicos a contabilidade (Parte 4.1 até 4.3).

A análise do discurso empregado no financial reporting nos permite captar traços da ideologia do grupo dominante brasileiro no período. Ou seja, queremos identificar qual a concepção de mundo que tal grupo desejou impregnar a fim de manter seus intuitos hegemônicos.

Já o estudo dos assuntos contábeis específicos nos fornecem elementos que permitem melhor compreender o porquê daquela ideologia (material), bem como identificar algumas contradições no incipiente sistema capitalista brasileiro. Ou seja, nos proporciona tanto estudar a causa, quanto à consequência.

Para esse fim, numa visão gramsciana, separamos a análise do discurso em duas frentes.

$\mathrm{Na}$ presente seção (3.1), abordamos a discussão do vínculo orgânico entre a estrutura e a superestrutura na realidade brasileira, nos seguintes aspectos: (3.1a) o café como símbolo do bem público; (3.1b) abandono das regiões desfavorecidas; (3.1c) o discurso elitista e (3.1d) a questão dos escravos. Nessa dimensão, também analisaremos a cooptação do intelectual rural (transformismo) com a política benévola do banco e do governo para com os pequenos e médios proprietários, sobretudos, os cafeicultores. 


\section{1 - O VÍNCULO ORGÂNICO ENTRE A ESTRUTURA E A} SUPERESTRUTURA

Nessa seção iremos abordar algumas evidencias do vínculo orgânico entre estrutura e superestrutura e a relevância do mesmo para a hegemonia ideológica do grupo dominante no Brasil durante o período estudado.

Iniciamos nossa análise com a disseminação da ideia de que o Brasil era só café e todos os esforços deveriam se direcionar para tal fim (3.1a).

Em segundo lugar, falaremos do abandono das regiões desfavorecidas do país em favor da dinâmica quase que exclusiva para os cafeicultores do sudeste brasileiro (3.1b).

Em seguida, abordamos o discurso elitista sobretudo com os funcionários, fazendo um comparativo com aqueles do alto escalão da instituição financeira (3.1c).

No quarto ponto, verificamos as ideias que tinham aqueles do grupo dominante acerca da questão dos escravos e todo o impacto com a sua abolição (3.1d).

Como argumento, percebe-se uma ligação clara entre as ideias que eram espalhadas e os interesses/fins materiais em que eram concebidas. 


\section{$\underline{3.1 \mathrm{a}-\mathrm{O} \text { café como símbolo do bem público }}$}

O intuito dessa seção é mostrar a atuação do Banco do Brasil em prol dos detentores dos meios de produção, sobretudo os cafeicultores, eclodindo com a disseminação da ideia geral de que estes deveriam ser incentivados a qualquer custo em detrimento do restante da sociedade brasileira. Verificaremos a atuação dos intelectuais do grupo dominante.

Como consequência, o momento presente nos permite verificar quais os resultados de tal política na vida dos brasileiros, com uma parcela gigante de excluído em detrimento de um pequeno número de privilegiados, ligados à dinâmica estrutural.

Com a transferência da família real e da Corte para o Rio de Janeiro, nos princípios século XIX assistimos com veemência a transferência do centro econômico e político para as mãos do Sudeste brasileiro, sobretudo financiado e sustentado pela produção cafeeira daquela região.

O Banco do Brasil não passa ao largo dessa situação já que o crescimento de sua carteira foi sustentado praticamente por capitais emprestados a esse tipo de devedor.

No início dos anos de 1870, começam a ser verificados as primeiras menções a importância do café para o Brasil e para a instituição financeira (BB, 1871):

(...) E sabido que as instituições de credito rural ou agrícola tem por fim resolver o problema de empréstimos de capitaes á lavoura a juro modico e lenta amortização, visto como a natureza desta industria não permite avultados lucros nem reproducção rápida dos capitaes nella empregados (grifo nosso). (....) Os fins da instituição não estão portanto satisfeitos: o prazo é curto, a contribuição suportada pelo devedor é grande na maioria dos casos superior ás forças da sua producção. O lavrador vê com terror approximar-se a época do vencimento da sua hypotheca, que o colloca á mercê do credor.

A regularidade com que tem sido feito o pagamento dos juros e amortização de nossa hypotheca parece contrariar o que levamos dito: mas essa regularidade, que honra sobre modo dos nossos lavradores, é conseguida á custa de sacrifícios, de que estão isentos sómente aquelles cujo débito é relativamente inferior ao valor da propriedade hypothecada (grifo nosso). São comissários que, com mira nas futuras colheitas, fornecem ao lavrador os recursos de que necessita para a satisfação de seus empenhos no banco. 
Este estado não póde durar muito tempo, e a deficiência de uma colheita é bastante para constituir a divida em mora, e coagir talvez a Administração do Banco a fazer valer seus direitos contra o devedor afim de acautelar os interesses do estabelecimento.

Com obviar a estas imperfeições que todos reconhecem no mecanismo da instituição, creada para o effeito de animar e facilitar os melhoramentos da produção agrícola, a industria quase excluisva deste paiz (grifo nosso). Segundo calculos razoaveis a lavoura em estado normal deve produzir a média de $6 \%$ do capital encorporado na terra, machinismo e outros instrumentos de trabalho.

E estipulando a lei como maximo dos empréstimos $50 \%$ do valor da propriedade de mutuario, é claro que este poderá destinar para juros e amortização uma anuidade até $12 \%$ do valor emprestado e que constitue a sua divida.

Se computarmos $6 \%$ para juro e o restante para armotização, conservando-se aquella annuidade inalterável, a divida estará extincta no prazo approximado de 12 annos.

Por este meio o lavrador, certo de que naquelle período terá saldado seu debito mediante o pagamento de uma annuidade que está nas forças de sua producção, cobrará animo, trabalhará com desassombro procurando melhorar sempre o patrimonio que um dia ha legar a seus filhos livre de qualquer onus.

Não escapa, por certo, á vossa illustração as vantagens que resultarião para o Banco do uma modificação neste sentido no regimen das hypothecas (grifo nosso).

Mas para que tenha lugar semelhante modificação é necessário dilatar o prazo da duração do Banco, e minorar o onus do resgate das notas circulantes reduzindo-o a uma proporção mais equitativa, afim de que o Branco do Brazil fique habilitado para continuar a prestar novos auxílios á lavoura que os demandar.

Como vêdes a realização destes idéias depende de concessões de favores que só os Altos Poderes do Estado podem fazer (grifo nosso).

Se depois de reflectido estudo julgardes que o Conselho deve impetrar aquellas alterações, é de esperar que os Poderes do Estado não recusarão os meios de que necessitamos para conseguir o fim de emprestar á lavoura capitaes a juro nunca maior de 6\%, com amortização lenta e desassombrada (grifo nosso). (p 14).

Nesse ponto, devemos lembrar que os estatutos do banco à época previam uma duração máxima de tempo para a existência da instituição e que devido as peculiaridades da produção cafeeira, lenta e vagarosa, os prazos dos empréstimos hipotecários deveriam ser longos, muito longos. 
Assim, sempre recorrendo aos poderes de estado, são mencionados em 1872, as regiões de atuação da carteira hipotecaria do Banco, bem como as condições requeridas anteriormente e agora aprovadas (BB, 1872):

A escassez na colheita do café o anno passado influio sobre a regularidade do serviço da divida hypothecaria.

Esta mora de caracter todo transitorio, nenhum receio inspira á Administração do Banco, que concedeu aos devedores prazo razoável para o pagamento de seus compromissos até á exportação da nova colheita. Minorados os encargos que pesão sobre os contratos hypothecarios, resultado que se há de conseguir com as providencias que solicitamos dos altos poderes do Estados, e alargada a zona das operações a outros municípios das províncias de S.Paulo e Minas, o futuro da Caixa Hypothecaria se apresenta debaixo de melhores auspícios. (...) Os capitaes não podem encontrar emprego mais seguro não só quanto á solvabilidade do devedor, como quanto á pontualidade na prestação da renda: além da garantia do emissor, o Banco do Brazil (que só por si é plena) e aos quaes se prende inteiramente a futura grandeza do paiz (grifo nosso). (p. 21).

Percebemos aqui a visão dominante de que a grandeza do país depende do sucesso da produção do café, responsável por alimentar os cofres do governo e dos acionistas. E que para atingir o objetivo, deveriam ser tomadas atitudes para com esse bem nacional.

Mesmo com todos os problemas advindos do risco de crédito, decorrente da dinâmica cafeeira, a postura era de complacência e ajuda direta e irremediável a tal grupo.

No ano seguinte, é mencionado projeto de lei que destina favorecimentos a essa classe crescente em território nacional, os detentores da "grandeza do paiz" (BB, 1873) :

Depois da vossa ultima reunião foi discutido e votado pela Camara dos Srs. Deputados um projecto de lei, concedendo, com algumas modificações, as medidas solicitadas pelo Banco do Brazil em sua representação aos Poderes do Estado. Remmetido para o Senado, está hoje dependente da approvação do segundo ramo do Poder Legislativo, de cujo illustração e patriotismo devemos esperar que ainda este anno seja convertido em lei do Paiz o 
referido projecto, para satisfação dos bem entendidos interesses deste Banco, e da lavoura, que anhela pelos favores ahi consignados (grifo nosso). (p. 5).

Vejamos que trata-se de uma questão de patriotismo, a conversão em lei de ajuda direta aos cafeicultores: a "satisfação dos desejos do banco e da lavoura."

Além disso, a benesse com esse tipo de devedor são explícitas (BB, 1873):

Continuão ainda em atrazo de juros e amortização alguns de nossos devedores hypothecarios.

$\mathrm{Na}$ cobrança a que se procede com actividade, procura a Administração conciliar os interesses do Banco com os desses devedores (grifo nosso), nem usando de excessivo rigor que redundaria no desmantelamento de muita propriedade agricola, nem tambem cedendo a suggestões de demasiada brandura que iria acorçoar a indolencia, e fazer perigar garantias do Banco. (p. 22-23)

Não demorou e a lei foi aprovada (BB, 1874):

Pela referida lei e subseqüente accordo, o prazo de duração do Banco foi prorrogado por mais 14 annos até 31 de Dezembro de 1900 , e a amortização annual de sua emissão era de 5 a $8 \%$ foi reduzida a $21 / 2 \%$; por sua parte, o Banco obrigou-se a elevar o capital de sua caixa hypothecaria a 25,000:000\$000, além do que fôr apurado nos titulos em liquidação pertencentes á mesma caixa, e a emprestal-os á lavoura dentro de tempo breve com juros de $6 \%$ e amortização de $5 \%$ ao anno. Além disso, a zona das operações hypothecarias, que só abrangia a Provincia do Rio e termos limitrophes das Provincias de S.Paulo, Minas e Espirto Santo foi estendida (...). (grifo nosso)

(...) a Administração do Banco , logo em começo do anno corrente preencheu o capital de 25,000:000\$000 da caixa hypothecaria.

Para harmonizar os Estatutos da Caixa Filial de S.Paulo com os da sua Matrz propoz o Conselho Director a reforma dos Estatutos que a região desde 16 de Outubro de 1867, os quaes forão approvados pelo decreto n.5,624 de 2 de Maio proximo passado (Annexo B), e começárão a vigorar desde 17 do corrente mez. A reforma procurou dar mais unidade e força á Gerencia, e estendeu o circulo das operações daquella filial, de modo que ella possa acompanhar o incremento das transacções em uma provincia que tanto se avantaja pela sua prosperiedade (grifo nosso). (p. 7) 
Abaixo, declaração datada de 1874 de D. Pedro II sobre as disposições da lei acima referida $(\mathrm{BB}, 1874)$ :

Dom Pedro Segundo, por Graça do Deos e Unanime Acclamação dos povos, Imperador Constitucional o Defensor Perpetuo do Brazil: Fazemos saber a todos os nossos Subditos que a Assembléa Geral Decretou e nós Queremos a Lei seguinte:

(...) $\S 2 .^{\circ} \mathrm{O}$ Banco do Brazil em sua secção hypothecaria não poderá nos emprestimos feitos á lavoura exigir juro superior a $6 \%$ ao anno, nem amortização annual maior de 5\% calculada sobre o total da divida primitiva: os juros e amortização serão pagos por semestres vencidos.

$\S 3 .^{\circ}$ Os empréstimos realizados pelo Banco do Brazil antes da data desta Lei, sob garantia de hypotheca de estabelecimentos agrícolas, ficão sujeitos á disposição do paragrapho antecedente. ( $\mathrm{s} / \mathrm{n})$.

Na visão do Banco (BB, 1874):

(...) O pensamento da lei de 17 de Setembro ultimo é habilitar o Banco (...) importantes auxílios á lavoura nacional ampliando suas operações (grifo nosso) (...).

(...) emprego dos 25.000:000\$ em beneficio da lavoura, foi applicada do modo mais efficaz, conciliando-se a cautella requerida pelo Banco (grifo nosso), que temia comprometter-se por um prazo menos de tres annos, com o interesse publico que deve corresponder ao importante favor ora concedido a esse estabelecimento. (grifo nosso) O Banco terá um anno para cumprir aquella indeclinável disposição da lei, gozando do pleno favor do resgate de suas notas na razão de $2 \frac{1}{2} \%$; se porém, findo este primeiro anno, não tiver realizado os 25.000:000\$ de empréstimos hypothecarios, no anno seguinte a taxa do resgate sobre a differença será de $4 \%$, no $3^{\circ}$ de $6 \%$ e de $4^{\circ}$ anno em diante de $8 \%$.

A circunscripção territorial para as operações hypothecarias é consideravelmente alargada.

Actualmente só comprehende o município da côrte, a provincia do Rio de Janeiro e os municípios limitrophes de S.Paulo, Minas Geraes e Espirito-Santo; pelo accôrde estende-se a todos os municípios destas províncias, e ás do Paraná e Santha Catharina. (...) recusaria o governo maior circunscripção, mas a administração do Banco não julgou isso praticável, allegando considerações ponderosas, e pedio ser dispensada de uma faculdade que poderia acarretar-lhe queixas de esperanças mallogradas, ao mesmo tempo que difficultasse talvez a organisação de outras sociedades locaes (grifo nosso). 
O decreto e regulamento de 22 de Julho de 1867 vedão empréstimos hypothecarios inferiores a 10:000\$000, ou superiores a 10:000\$000, ou superiores a 120:000\$000. Aquelle mínimo tinha sua razão de ser na garantia precária de estabelecimentos agrícolas de tão diminuta importancia. Não osbtante, porém, com a dita restriç̧ão foi censurada no senado por nimiamente rigorosa para com a pequena lavoura, julgou-se conveniente suppprimil-a agora que se dota melhor a repartição hypothecaria, e o Banco inspira bastante confiança por sua solidez e pela experiencia de sua administração.

O maximo de 120:000\$000 foi mantido, para a mais extensa e equitativa distribuição dos auxílios do Banco, (grifo nosso) e não será de certo considerado muito restricto, desde que se attende á regra legal que prohibe emprestimos excedentes da metade ou tres quartos do valor dos bens hypothecados, segundo são estes ruraes ou urbanos. (p. 4).

Nesse sentido, vejamos que política interessante, focar uma região (sul-sudeste), antes limitando o valor mínimo, por ora não aprovado pelo senado, como consequência, mais produtores pequenos e médios teriam acesso a esse crédito indiscriminado, cooptando-os seus interesses e alinhando-os aos do grupo dominante.

Numa visão materialista, o fenômeno da cooptação de membros de outras classes se tornam fundamental para o enforcement da concepção de mundo hegemônica da classe dirigente brasileira. E o limite máximo, assumiu-se que era irrelevante sua colocação ou não, devido às restrições com as garantias das operações hipotecarias, que funcionaria como uma ferramenta anti-concentração não há motivos de sua existência.

Inclusive em muitos momentos, o Banco do Brasil foi acusado por não auxílio adequado aos cafeicultores (BB, 1878):

Para que esta carteira podesse prestar serviços do que os que tem realisado e continúa a realisar, fôra preciso que seu agente--- as letras hypothecarias--- encontrasse agasalho na mão dos capitalistas, contentando-se estes com o juro de 5\%; o que não é fácil conceberse em um paiz novo, dispondo de poucos capitaes e quando os existentes encontrão emprego mais lucrativo.

Vozes autorisadas têm accusado o Banco nas Camaras, na imprensa, e ainda ha poucos dias no Congresso da Lavoura, da falta de cumprimento de suas obrigações; mas, força é confessar, que essas accusações forão vagas e não conseguirão desfazer a verdade, que é só uma. (grifo nosso) 
(...) No intuito de dar maior desenvolvimento á carteira hypothecaria, prestando ao paiz real serviço (grifo nosso), é que o Banco em Janeiro de 1875 iniciou a $1^{\text {a }}$ emissão de letras hypothecarias, por isso que estando esgotado o seu capital, não podia ir além daquillo a que se obrigára, nem pedir recursos que não fossem os autorisados ás sociedades de credito real, e para que tinha faculdade.

Como, pois, desconhecer-se que o Banco emittindo letras a juro de $5 \%$ e cobrando $6 \%$ dos lavradores, e isto na pequena escala em que o tem feito, não póde auferir lucros que compensem as eventualidades de liquidações, despezas de material e pessoal.

Por tão pouco não valeria a pena soffrer tão graves accusações; mas o móvel que guia o Banco é outro: ---prestar serviço ao paiz (grifo nosso).

Não entrarei em outra ordem de argumentos.

Meu fim é defender a administração do Banco, provando a toda a luz, que este tem cumprido o seu contracto, e effectivamente empregado, ou á disposição da lavoura mais de 25:000:000\$000 em dinheiro (grifo nosso), e quem compulsar os balanços desde o dia 31 de Dezembro de 1874 até hoje, verificarà a exactidão do exposto.

Sirvão estas palavras de protesto ás muitas accusações que ao Banco têm sido dirigidas até por aquelles que delle têm recebido auxílios directos (grifo nosso). (p. 32).

$\mathrm{Na}$ sede de mais recursos, em um país novo, ainda com os dramas na política monetária e cambial, os agricultores em muitas ocasiões questionavam o papel do banco, que inclusive forjou o dispositivo legal limitando a 25 mil contos a carteira hipotecária.

Porém, é interessante o exposto no último parágrafo pelo presidente da instituição: "ás muitas accusações que ao Banco tem sido dirigidas até por aquelles que delle tem recebido auxilios directos." O vínculo material e o apelo ao lucro indiscriminado são a tônica nessa formação específica.

A crise econômica do final dos anos 70 tem causa bem explicada pela Instituição, o que reforça seu caráter (BB, 1879):

O movimento commercial foi pouco activo por causas geralmente conhecidas, entre as quaes nota-se a baixa consideravel do preço do café nos mercados consumidores, a secca persistente em algumas províncias do Norte, que tem diminuído a producção do paiz e aggravado os encargos do Estado (...)(grifo nosso). 
Continuão os mutuarios hypothecarios a satisfazer com mais ou menos regularidade os pagamentos de suas prestações de juros e amortisações, de sorte que de 534 contratos de longo prazo na importancia de 22.989:380\$490, apenas 82 estão em atrazo, e destes a maior parte de uma só prestação, que costumão cumprir com mais alguma demora; e dos 202 contratos de curto prazo ora existentes na somma de 7.781:910\$111, achão-se em atrazo de amortisações e juros 54, de amortisações sómente 26 e de juros 8. (p. 5).

A ideia interessante que a crise ocorria primeiro em diminuição das receitas, com a baixa do preço de café, mas interessante notar que a responsabilidade recai sobre os Estados do Norte, devido à seca e as constantes remessas de capitais efetuadas à época: eram vistos como encargo do Estado. Porém não se compara com a relação monetária entre o banco e o governo, representado sobretudo na atenção especial às províncias do sudeste.

As inovações advindas com o café também são motivos de comemoração (BB, 1880 e 1881)::

Assim tambem fôra muito para desejar um systema de armazenar nosso café, que désse base segura ao contrato de emprestimo sobre penhor. Estas innovações trarião grandes elementos de vida para as instituições de credito com muito proveito do commercio e da riqueza publica (grifo nosso).

Tratando da repartição hypothecaria, devo informar-vos que é lisongeiro o seu estado, e que, dentro de suas forças, continúa ella aprestar serviços á lavoura (grifo nosso)." (1880, p. 6)

(...)

Grande tem sido o incremento das operações da Caixa Fiial de S. Paulo depois se forão estabelecidas correspondencias nas cidades de Santos e Campinas, que estão estando relevantes serviços ao commercio e á lavoura daquella importante provincia.

A administração do Banco aproveita esta ocasião para agradecer aos dignos serviços da Caixa Filial a coadjuvação, que dos mesmo tem recebido (grifo nosso)." (1881, p. 7)

Porém, as medidas se tornam mais diretas e específicas nos anos de 1880 sendo efetuado, inclusive, um Acordo com o Governo Imperial em 1888, devido às 
"intempéries" causadas pela abolição da escravatura. Vejamos as condições desse Accordo (BB, 1888):

ACCORDO celebrado entre o Governo Imperial e o Banco do Brazil em 3 de agosto de 1888 para auxilios a lavoura 5.a Nenhuma hypotheca se fará por somma menor de dous contos de réis nem maior de vinte contos de réis (...)

6.a O juro será para todas de seis por cento (...) 7.a A zona estabelecida para estas operações comprehenderá as provincias de S. Paulo, Rio de Janeiro, Minas Geraes e Espirito Santo, sendo destinados quatro mil contos de réis á primeira e oito mil contos de réis para ás tres ultimas.

(...)

9.a O Banco facilitará estas operações, tanto quanto puder (grifo nosso), afim de ter sempre empregado o referido capital (...)

10.a O capital fornecido pelo Governo Imperial não vencerá juro a seu favor (grifo nosso), mas ser-lhe-á restituido integralmente no fim do prazo do contrato, correndo os lucros e prejuizos por conta do Banco (...)

11.a Por virtude deste accordo fica o Banco dispensado da multa de oito por cento a que está sujeito (...) para a execução da Lei 2.400 de 17 de Setembro de 1873 (...) (p. 41-42)

Esse Accordo de agosto de 1888 do Banco do Brasil mostra muito bem as generosas relações com o poder dominante já que destina 12 mil contos para o Sudeste brasileiro, os cafeicultores. A taxa também é diferenciada, 6\% contra 10\% nos empréstimos "normais". E lembrando que o "Banco facilitará estas operações, tanto quanto puder (...)" como apontado acima.

Porém também percebe-se a tentativa do Banco de incluir nessa realidade os pequenos produtores da região (contratando até "dous contos"), numa tentativa de aumentar a massa dos adeptos da ideologia cafeeira brasileira através das benesses material tanto do banco quanto do Estado na atuação direta na questão cafeeira. Uma tentativa de transformismo por parte dos intelectuais do grupo dirigente. Porém deixa de lado os produtores de menor escala, de cunho familiar que não consegue financiar os referidos "dous contos".

O Banco também sai ganhando, já que se trata de um dinheiro sem custo “já que não vencerá juro algum” (p. 42) para o Império: corre apenas o risco de crédito, altíssimo 
na época e não refletidos na contabilização desses títulos duvidosos como veremos na Parte 4.2.

Adicionado ao grave problema de liquidez que o Banco sofria nesses tempos, com avultadas somas emprestadas mais notadamente a Corte e as regiões mais abastadas do país e aos produtores de café, que já nas duas últimas décadas do século sofrem duros golpes na sua dinâmica produtiva, com o fim da mão de obra não remunerada, como eles falavam à época $(\mathrm{BB}, 1888)$ :

No exercicio findo nota-se um decrescimento no movimento da Caixa, devido sem duvida a causas, que não ignoraes, de perturbações econômicas que não deixarão de actuar sobre as transações ordinarias do commercio, produzindo uma certa paralysação e estagnação dos negocios. (BB, 1888, p. IV)

Apezar da crise, que ha longos annos atormenta a nossa lavoura, fonte de producção do paiz, com a questão da transformação do trabalho servil, a propriedade agricola ainda apresenta base segura para a fundação de instituições de credito real (...)

Quando a propriedade agricola tiver perdido totalmente o seu valor, tudo ficará destruido, a propriedade urbana, os titulos da divida publica, as acções e debentures das Companhias, não terão mais valor algum, porque a lavoura é ainda a exclusiva industria do paiz e a fonte perenne da riqueza publica $e$ particular (grifo nosso).

É cedo para avaliar-se as consequencias da Lei de 13 de Maio sobre o movimento da Carteira hypothecaria.

A prudencia e tino deste estabelecimento, secundado pelos auxilios prestados pelo governo, directa ou indirectamente a lavoura, é de esperar que superarão as difficuldades de momento na substituição de braços livres para laborarem os estabelecimentos agricolas.

Neste intuito, o governo imperial celebrou com o Banco o accordo de 3 de Agosto para constituir-se uma nova secção de credito agricola com o capital de $12.000 .000 \$ 000$ para auxiliar os lavradores na colheita da safra. (BB, 1888, p. VI)

Mais uma vez o Banco não se recusou de cooperar com o seu capital e serviços em favor da nossa lavoura, que prende-se aos interesses vitaes do commercio e ao futuro do paiz. (grifo nosso) (p. VII)

Como bem lembrado por Bianchi (2008): a "expansão (dos interesses) não poderia aparecer como a realização dos interesses dos grupos diretamente beneficiados" (p. 
175-176), devendo se aparentar como uma "expansão universal" como se fosse expressão de toda a sociedade.

Nessa direção, essa concepção da classe dirigente, isto é, a ideologia deve se espalhar para toda a sociedade (Portelli, 1977): para isso a filosofia e história se identificam nesse momento: "qualquer filosofia histórica, isto é, orgânica deve prolongar-se através do senso comum", que é garantido pela "política, que assim assegura a unidade ideológica do bloco histórico.” (p. 25).

Assim, começamos a verificar o argumento do Banco e das classes dominantes de que o café representa o bem para o Brasil e que sua salvação é questão nacional, de Estado, já que como bem citado mais acima (BB, 1888):

(...) Quando a propriedade agricola tiver perdido totalmente o seu valor, tudo ficará destruido, a propriedade urbana, os titulos da divida publica, as acções e debentures das Companhias, não terão mais valor algum, porque a lavoura é ainda a exclusiva industria do paiz e a fonte perenne da riqueza publica e particular. (p. VII)

Com o advento da República (1889) as relações se tornam mais diretas, assim como referido por Netto (2009).

Lembremos pois que tanto os militares quanto a própria república oligárquica era balizada pelos mesmos ideais materiais, já que seu poder político era financiado quase que de maneira exclusiva pelos rendimentos do café (BB, 1890):

Ainda uma vez a Administração do Banco consultou, menos sus interesses, do que os da lavoura, a quem tem auxiliado ha longos annos, sem outra preoccupação que não seja a de cumprir lealmente, os compromissas para tal fim contrahidos com o Governo (grifo nosso).

$\mathrm{O}$ resultado, porém, deste succinto balanço de lucros e perdas, procedentes da liquidação verificada, demonstra que o Banco não tem auferido dos auxilios prestados á lavoura vantagens taes, que podessem induzil-o a aceitar novos sentimentos de patriotismo pelo mesmo Governo, que se manifestava então empenhado em debellar a crise do trabalho, com que luctava a lavoura (grifo nosso). (p. 32) 
Na república oligárquica o discurso era o mesmo (BB, 1894):

Elles revelam em alto gráo o tino, o acerto e a prudencia com que foi sempre gerida esta Carteira do Banco do Brazil. Ainda mais: baseados os emprestimos principalmente na lavoura do café, foram na sua maioria os compromissos saldados com pontualidade, mesmo no periodo difficil da transformação do regimen do trabalho escravo para o trabalho livre, pontualidade esta que por si só faz entrever corollarios do maior valor : a pubberdade do nosso solo e a probidade da classe agricola (grifo nosso). (p. 7)

Além da própria operação, como vista mais acima (de menos de 1\%a.a. de spread e prazos superiores a 10 anos), a problemática operacional enfrentada pelos agricultores com o fim do regime servil, a tolerância e ajuda mútua continua.

Com a crise de preços do final do século XIX, os auxílios continuam (BB, 1898, 1899, 1900):

Os soffrimentos por que está passando a principal industria do paiz, a lavoura, pela baixa extraordinaria que teve o preço do café, muito vai contribuindo para procrastinar a terminação da crise que se pronunciou nas nossas principaes praças do commercio desde 1892.

A historia demonstra que semelhantes crises affectam periodicamente as nações. (grifo nosso)

A do algodão nos Estados Unidos, pronunciada em seguida á abolição da escravidão, tem muitos pontos de semelhança com a do café que ora observamos em nosso paiz.

Esses paizes lutaram resolutamente, as difficuldades desappareceram e os dias de prosperidade voltaram.

Confiemos que o mesmo acontecerá entre nós.

Bem longos têm sido os mesmos soffrimentos; mas nem sempre será assim: «quanto mais longa vai a noite, mais proxima está a alvorada,» diz o proverbio (grifo nosso). (1898, p. 17).

(...)

A persistente baixo do preço do nosso principal producto, o café, e outras de vós bem conhecidas, determinaram certa pressão na praça, resultando d'ahi algumas fallencias, parte das quaes já estão liquidadas, sem terem, felizmente, trazido abalo ao credito do commercio, que, em abono da verdade, arrostando todos os sacrificios, tem sabido desempenhar-se honestamente dos seus compromisso. (1899, p. 10 e 11) 
A crise que, assoberbou a nossa praça, devida não só ao retrahimento e deslocação do meio circulante, mas também á baixa do preço do café, vae-se desvanecendo, e brevemente se tornarão regulares as transacções, si, como espero, a circulação monetaria continuar a melhorar e si se mantiveram as cotações que ultimamente têm predominado no mercado, em relação ao principal producto de nossa lavoura.

Dos balanços insertos (...) comprehendereis que a Administração não tratou senão de fortalecel-as afim de consolidar o credito do estabelecimento. (1900, p. 9)

Percebemos que diante da superprodução do café em vista, assim como apontado por Netto (2009) e com a crise do excesso de emissões, o relacionamento entre Banco, Estado e Café se tornou a dinâmica principal, pelo menos nos trinta primeiros anos do século.

\section{Conclusão da seção:}

Historicamente, desde os primórdios da colonização portuguesa, fomos sempre um país agroexportador/extrativista, geralmente monocultural: passamos pelo pau-brasil, açúcar, ouro e culminamos no café nos séculos XIX/XX.

Nossa construção histórica-moral foi elaborada com esse pano de fundo.

A transferência da corte no início dos oitocentos muda radicalmente o centro econômico brasileiro. A necessidade monetária torna-se escambrosa.

Consequentemente, o café aparece como esperança e, como verificado mais acima, talvez a única, no objetivo de geração de divisas para esse país novo, com problemas sociais antigos.

Assim, verificamos em primeiro lugar, que o Banco do Brasil foi utilizado como instrumento direto no fornecimento de crédito, em condições extremamente favoráveis para os cafeicultores, sobretudo os grandes, médios e pequenos. Um jogo bem arquitetado entre os dentetores dos meios de produção (proprietários de terras, governo e Banco) que trazia vantagens diretas a esses envolvidos.

Porém a agricultura familiar, de subsistência, fora abandonada com os limites operacionais relativos aos empréstimos.

Em segundo lugar, em termos da dialética, era necessário impregnar a concepção de mundo da classe dirigente nacional em todos: criar a ideia que a questão do café não 
era um problema apenas dos agricultores que se dedicavam ao gênero, mas da nação como um todo. O símbolo da riqueza pública deveria ser incentivado a qualquer custo. Mesmo com as mudanças do poder político, a tônica do discurso continua monocrômica.

Essa transformação do café em bem público é uma tentativa clara do poder dirigente de fazer transparecer as ações do grupo dominante como não apenas com o objetivo de atingir seus interesses, mas sim da sociedade como um todo.

Como consequencias dessas observações, na análise gramsciana verificamos a (a) criação da superestrutura necessária à estrutura, com a criação da "realidade" de que o café era um bem nacional, de todos; (b) o sistema de soliedariedade das classes dominantes em relação às outras classes, em geral, os grupos auxiliares, culminando no transformismo do intelectual rural, mais notadamente aquele da porção meridional brasileira; (c) o controle do camponês, o desvirtuando do projeto de revolução e (d) o isolamento das classes subalternas, principalmente aqueles localizadas no norte e nordeste do país. 
$\underline{3.1 \mathrm{~b} \text { - Abandono das regiões desfavorecidas: o contraste com as regiões mais ricas }}$

No exposto acima verificamos o discurso empregado em prol dos interesses dos cafeicultores, do banco e do Estado como um objetivo comum.

Assim, indicamos a atuação da política de empréstimos da instituição como extremamente concentrada nas regiões produtoras daquele gênero agrícola, com todos as suas intrínsecas benesses.

Agora abordaremos a atuação do banco para com as regiões mais desfavorecidas do país. Nesse interim, percebemos a ideia geral e presente do atraso econômico e social das regiões setentrionais brasileiras, fato esse extremamente impactado pelas políticas anteriores, como as do século XIX. O interesse material dos nossos dirigentes se sobrepõe aos interesses da nação como um todo.

Iniciemos nossa análise, com uma política que visa "atender" aos interesses de outras regiões e classes do país, a questão das Caixas Filiaes, nascidas junto com o Banco do Brasil na década de 1850, produto das agências dos bancos privados fundidos. As primeiras além de São Paulo e Ouro Preto, foram as do nordeste brasileiro, notadamente em Pernambuco, Bahia, Maranhão e Pará. (BB, 1857):

Estes importantes Estabelecimentos apenas contão hum anno de existencia: em tão curto período não he possível avaliar a sua importância futura pelo movimento actual (...) e servido de grande auxiliar, principalmente ás Praças da Bahia e Pernambuco na epocha das safras. (p. 8)

Naquelas duas últimas localidades (MA e PA) era de se esperar a atuação do Banco em prol do bem público e devido às peculiaridades e a pobreza extrema dessas, atuasse com um vínculo mais estreito aos desfavorecidos.

Essa caixas não eram agencias no sentido literal, mas tinham uma autonomia, com estatutos e diretorias próprias. (BB, 2010). E crescem rapidamente: no segundo ano de funcionamento $(\mathrm{BB}, 1858)$ : 
Estes estabelecimentos tem correspondido em geral ás esperanças que presidirão á sua creação - suas operações progridem, auxiliando as praças onde impera sua acção, e facilitando as transacções de umas para outras (...) (grifo nosso).

\begin{tabular}{|l|r|r|}
\hline & $\begin{array}{r}\text { Valor - Ano bancal } \\
\mathbf{1 8 5 8}\end{array}$ & $\begin{array}{r}\text { Evolução } \\
(\%)\end{array}$ \\
\hline $\begin{array}{l}\text { Carteira em } \\
31.05 .1857\end{array}$ & 10.929 .574 .041 & \\
\hline $\begin{array}{l}\text { Carteira em } \\
31.05 .1858\end{array}$ & 16.119 .258 .023 & $147,48 \%$ \\
\hline $\begin{array}{l}\text { Diferença para } \\
\text { mais }\end{array}$ & $\mathbf{5 . 1 8 9 . 6 8 3 . 9 8 2}$ & $\mathbf{4 7 , 4 8 \%}$ \\
\hline $\begin{array}{l}\text { Emissão em } \\
\text { 31.05.1857 }\end{array}$ & 16.892 .590 .000 & \\
\hline $\begin{array}{l}\text { Emissão em } \\
31.05 .1858\end{array}$ & 20.975 .330 .000 & $124,17 \%$ \\
\hline $\begin{array}{l}\text { Diferença para } \\
\text { mais }\end{array}$ & $\mathbf{4 . 0 8 2 . 7 4 0 . 0 0 0}$ & $\mathbf{2 4 , 1 7 \%}$ \\
\hline Lucro - 1858 & $\mathbf{1 . 0 3 6 . 8 8 4 . 9 5 6}$ & \\
\hline
\end{tabular}

O movimento de fundos entre as caixas e o Banco central deo em resultado hum saldo a favor deste de Rs. 2.544.085\$739, devido na sua maior parte aos saldos do Thesouro tomados pelo Banco, e á diminuição de transacções entre esta Praça e as do Norte do Imperio. (p. 14-15).

Em 1860 são narradas a diminuição da carteira das Caixas Filiaes, mesmo essas sendo mais rentáveis que aquela do Rio de Janeiro. Notemos também a importância residual dadas às operações nas províncias mais desfavorecidas (PA e MA):

Tabela 3 - Lucro e relação com capital effectivo (fonte BB, 1860, p. 12)

\begin{tabular}{l|r|r}
\hline Caixas Filiaes & Lucro - 1860 & Lucro/Capital effectivo \\
\hline Ouro Preto & $26: 145 \$ 983$ & ou 26.14 por \% \\
\hline S. Paulo & $199: 279 \$ 853$ & ou 24.90 por \% \\
\hline Rio Grande do Sul & $81: 413 \$ 959$ & ou 16.28 por $\%$ \\
\hline Bahia & $160: 326 \$ 044$ & ou 8.01 por $\%$ \\
\hline Pernambuco & $268: 328 \$ 204$ & ou 13.41 por $\%$ \\
\hline Maranhão & $48: 397 \$ 146$ & ou 7.56 por $\%$ \\
\hline Pará & $60: 522 \$ 524$ & ou 15.13 por $\%$ \\
\hline
\end{tabular}


Porém apesar dessa interessante lucratividade, no ano de 1867 é anunciada a descontinuidade das operações das caixas filiais Rio Grande do Sul, Pará, Maranhão, Bahia e Pernambuco; foram mantidas as de São Paulo e Ouro Preto. Os motivos fornecidos foram $(\mathrm{BB}, 1867)$ :

Á sua apreciação não é por certo lisonjeira para os interesses do Banco do Brasil, de cujos sacrifícios em favor da maior parte das suas filiaes só colheo a vantagem de concorrer para o progresso e desenvolvimento do commercio e industria das praças em que as estableceo.

Esses sacrifícios, porem, não podem perpetuar-se sem más consequencias para os legítimos interesses d'este estabelecimento (grifo nosso).

Se por um lado o resultado dos algarismos que representão os lucros de cada uma das caixas em relação ao seu capital effectivo, mostra com evidencia a sua insufficiencia para cobrir não só os prejuízos a que estão expostos os estabelecimentos de credito, mas até despeza necessária ao seu costeio; por outro lado a nova phase em que entrou o Banco do Brasil, e os effeitos da novíssima lei de 12 de setembro de 1866, aconselhão a concentração de todos os seus recursos para que o bom exito da reforma decretada possa corresponder á vossa expectativa.

(...)

A Directoria resolveu liquidar as caixas do Rio Grande do Sul, Pará e Maranhão (...) as únicas que julga conveniente manter, que são as de S.Paulo e Outro Preto (grifo nosso).

Para mais facilmente realisar esta medida a Directoria solicitará authorisação do Ministerio da Fazenda para que as operações de resgate e substituição das notas destas duas caixas possão ser feitas por intermédio das Thesourarias das respectivas províncias. (p. 17).

Comparemos então que os incentivos à "importante província" paulista já eram destacados ano antes $(\mathrm{BB}, 1866)$ :

(...) A directoria da caixa filial de S.Paulo diz que: ---- estando reconhecido que as operações d'esta caixa filial são de máxima utilidade para a província, e de que não menos proveito para a praça do Rio de Janeiro, as quaes por ellas entretem e liquidão os seus negocios de compra e venda, com um centro de valiosa producção e de grande consumo (grifo nosso); devendo supôr-se que o proximo trafego de via ferrea desde Santos a Jundiahy, e o proseguimento, que se emprehende d'essa linha a abraçar outros pontos da província enriquecidos pela lavoura (grifo nosso); a 
cultura do algodão cuja importancia, há tres annos, nem merecia mencionar-se e que sobe hoje a 250 mil arrobas, e promettendo elevar-se brevemente a uma exportação consideravel; o commercio que há de desenvolver-se sob estas condições de trabalho e de actividade de transporte fará certamente d 'esta caixa filial um poderoso e influente intermediário, se for habilitada com os recursos de que em breve tempo carecerá para acompanhar a nova phase, que parece incontestavel ainda aos menos crédulos. Termina solicitando que seja considerada a caixa filial de $S$. Paulo em relação com o seu prospero andamento e com o que promette em um futuro muito proximo, apenas tão distante quanto podem estar os novos elementos de industria $e$ commercio da província. (grifo nosso). (p. 14).

Somente em 1870 foram de fato encerradas as atividades das respectivas caixas (BB, 1870):

Dentro do anno bancario liquidarão-se as Caixas da Bahia, Maranhão, Pará e Rio Grande do Sul, e para você conhecimento consigno aqui o resultado dessas liquidações. (p. 6).

Outra atuação direta na instituição para com as regiões menos desenvolvidas (se assim podemos dizer), ainda na época do Império, com a sua ajuda às províncias do norte, datada de 9 de outubro de 1888, mesmo ano da ajuda às províncias cafeicultoras $(\mathrm{BB}, 1888)$ :

Neste pensamento, ainda o governo imperial celebrou com o Banco outro accordo de 9 do corrente, para levar também auxilios á lavoura do Norte, nas províncias de Pernambuco, Alagôas, Parahyba e Rio Grande do Norte (grifo nosso) (...)

ACCORDO celebrado entre o Governo Imperial e o Banco do Brazil em 9 de Outubro de 1888 para auxilios a algumas provincias do Norte

1.a O Banco do Brazil estabelecerá na cidade do Recife uma secção de Credito Agricola com o capital de tres mil contos de réis (...) sendo metade fornecida pelo Governo Imperial, por prestações de quinhentos contos de réis, á proporção que cada uma for empregada em emprestimos á lavoura, e metade pelo fundo capital da repartição hypothecaria do mesmo Banco.

5.a Nenhuma hypotheca se fará por somma menor de dous contos de réis nem maior de dez contos de réis (...) 
7.a A zona estabelecida para estas operações comprehenderá as provincias do Rio Grande do Norte, Parahyba, Alagôas e Pernambuco, sendo destinados trezentos contos de réis á primeira, quatrocentos contos de réis á segunda e a terceira e mil e novecentos contos de réis á ultima. (grifo nosso). (p. 45-46).

Já percebemos a diferença dos Accordos Imperiais no tocante ao valor: 12 mil contos contra 3 mil para as províncias mais pobres, sendo apenas metade financiada diretamente pelo Governo: neste, o capital da carteira é dividido em parte igual com o Banco do Brasil. E vejamos que para as províncias de fato mais pobres, como Rio Grande do Norte, Parahyba e Alagôas os recursos destinados são praticamente irrisórios, sendo apenas relevante aquele fornecido à Pernambuco, já secularmente dominado pelo grandes engenhos de açúcar da monocultura latifundiária brasileira.

Correspondem, pois, ações claras de aumento da base do grupo de aliados e tentativas de também contemplar os "excluídos", quando na verdade se contempla apenas os "incluídos".

Todavia, novamente, o pequeno empréstimo, denominado "auxílio" foi extinto e entrou em liquidação isso já no início dos anos 90, devido à escassez do meio circulante nas regiões mais importantes do país (BB, 1892):

Continúa a ser melindroso o estado da nossa praça.

Causas que vos não são desconhecidas, e avultam como mais proximas, a escassez do meio circulante, pela sua exportação em massa para fóra d'esta Capital, e o retrahimento dos capitaes particulares, receiosos de se comprometterem na grande desvalorisação que tudo assoberba, tem actuado gravemente sobre todas as transacções, difficultando o credito e embaraçando a marcha regular dos negocios.

Já na carta que abaixo transcrevo e que dirigi ao Sr. Ministro da Fazenda, em 23 de Fevereiro do corrente anno, quando este Banco teve a honra de ser consultado por S. Ex. sobre a aorigem d'aquellas difficuldades e os meios de removel-as, assignalei esses motivos como os principaes para determinarem a crise que observamos, e opinei pela conveniencia de intervir o governo no sentido das leis n. 2.565 de 29 de Maio de 1875 e n. 3.263 de 18 de Julho de 1885."

" $1^{\circ}$ A escassez do meio circulante é de facto incontestavel; a sua larga exportação para os Estados do Norte da Republica, a sua internação continua nos Estados visinhos d'esta Capital, e, por outro lado, o retrahimento absoluto dos capitaes particulares, naturalmente timidos e receiosos pela desconfiança inevitavel, n'uma conjunctura 
assim difficil e de diminuição de valores, aggravada pela consideravel e extraordinaria baixa do cambio, tudo, em summa, explica por modo irrecusavel o facto, que ahi está palpavel, não sendo possivel á primeira vista dizer até onde vão as legitimas necessidades das transacções normaes d'esta importante praça, nem tão pouco asseverar, com exactidão, onde por ventura possa começar qualquer demasia, condemnavel, de sua actividade commercial e industrial. (p.11)

(...)

Continúa a liquidação dos emprestimos aos Estados do Norte, a cargo dos nossos correspondentes em Pernambuco, os honrados Srs. Pereira Carneiro \& C., que a estão realisando sem vexar os devedores. (p. 29).

Vide a posição relativamente pequena de operações em 1894 (BB, 1894):

A liquidação dos emprestimos aos Estados do Norte, continúa a cargo dos nossos zelosos correspondentes em Pernambuco, Srs. Pereira Carneiro \& $\mathrm{C}^{\mathrm{a}}$.

A somma dos emprestimos, que no anno anterior era representada pela quantia de 1.284:370\$911, está hoje reduzida a 838:093\$571, sendo:

Em

Pernambuco

$326: 607 \$ 158$

Alagoas.

$180: 787 \$ 193$

Parahyba

$228: 650 \$ 050$

Rio Grande do Norte. $102: 040 \$ 170$

Total. $838: 093 \$ 571$ (p. 3)

Conclusão da seção:

Como argumento dessa seção, verificamos a postura da sociedade política, e tembém da sociedade civil acerca da questão com as classes desfavorecidas, sobretudo aquelas afastadas da região da dinâmica cafeeira (Norte, Nordeste e Centro-Oeste).

O abandono de outrora se faz sentir ainda nos dias atuais.

Assim, como consequencia dessa realidade, obervamos em primeiro lugar o abandono as classes subalternas e, em segundo, a tentativa de transformismo do intelectual rural e das classes subalternas (e seus intelectuais), com as políticas específicas.

Com o escasso fornecimento de numerário, através do envio de notas ou empréstimos propriamente ditos, a região supracitada, principalmente aqueles não ligados aos 
latifúndios do nordeste, gozadores de privilégios e poder em outras épocas, ficou alienada de todo o progresso econômico, impelindo-os de todos os “desenvolvimentos" advindos com o capitalismo nascente.

Foram praticamente deixados à sorte de sua existência. Seria essa evidência da exclusão dessa classe do sistema hegemonico, como bem apontado por Gramsci (1999), ao definir a classe subalterna.

Em relação às políticas específicas, verificamos que até a nomenclatura designada tem caráter de dissimulação, como por exemplo, a "Ajuda aos Estados do Norte".

Essas ações não visavam, como numa leitura primeira, mais superficial, o desenvolvimento ou progresso das regiões atendidas.

Pelo sua duração, extensão e caráter, percebemos que foi em primeiro lugar empréstimos para regiões outrora envolvidas com a monocultura exportadora, como Pernambuco, atendendo a interesses materiais diretos, mas continham também elementos, em segundo lugar, para um agricultor menor, porém não tão menor, aquele de subsistência: mais uma tentativa de cooptação de interesses, tanto do intelectual rural, quanto alguns das classes subalternas. 


\section{$\underline{3.1 \mathrm{c}-\mathrm{O} \text { discurso elitista }}$}

A cultura organizacional reflete as ideologias vigentes no campo das relações sociais mais amplas. O financial reporting do Banco do Brasil traz valiosas contribuições no estudo de um discurso elitista na valorização da chefia, mais notadamente da Alta Administração em detrimento dos funcionários, tidos como de menor escalão.

Em boa parte dos Relatórios que tivemos acesso são descritas por parte da Administração, uma visão dos trabalhos dos funcionários e chefes. Vejamos alguns momentos, situados em todos os períodos de nossa pesquisa (BB, 1857, 1860, 1862, 1870, 1898, 1899, 1900):

O serviço das diversas repartições he satisfactoriamente desempenhado, sendo por isso digno de louvor o modo por que os empregados, mormente os chefes, cumprem seus deveres. (1857, p. 11) (...)

O serviço das differentes repartições do Banco, apezar de arduo e por demais trabalhoso em consequencia do grande augmento de expediente que vão tendo, á proporção que se vão tambem ampliando as transacções; he contudo satisfactoriamente desempenhado; devido isso ao zelo e aptidão da maior parte dos empregados, principalmente pelo que respeita os Chefes.

A Directoria attendendo ao acréscimo trabalho e á insufficiencia dos ordenados de todos os empregados do Banco, julgou praticar hum acto de justiça melhorando sua posição, e marcando-lhes os vencimentos que se achao indicados na tabella anexa sob n. 9.

As diversas Repartições do Banco continuam a funccionar com regularidade, devendo accrescentar que em geral os Empregados cumprem dignamente os seus deveres.

Tendo resignado o cargo de director do Banco o sr. Francisco Xavier Pereira (...) O sentimento que causou á Directoria do Banco a perda dos valiosos serviços que recebera da intelligencia, e consumada experiencia daquele digno companheiro, só pode ser compensado pelo auxilio que lhe prestará sem duvida a reconhecida ilustração, e zelo da pessoa que o substituio. (1860, p. 15). (...)

O serviço das diversas Repartições do Banco é satisfactoriamente desempenhado, cumprindo os seus empregados, e com especialidade os Chefes, com os deveres que estão ao seu cargo. (1862, p. 16).

As diversas repartições do Banco continuão a funccionar com toda a regularidade, e os seus empregados tem cumprido e bem desempenhado seus deveres. (1870, p. 14)

(...) 
$\mathrm{E}^{\prime}$ grato reconhecer que, em geral, os Empregados do Banco têm desempenhado com regularidade seos deveres distinguindo-se os Chefes se serviço pelo zelo e dedicação que tratam os interesses do Banco. (1898, p. s/no $)$.

(...)

O Conselho encontrou a maior fraqueza por parte da Directoria quer para examinar os documentos, quer para obter as informações, que julgou necessarias; e deve accrescentar que em trabalhos de alguns empregados, que teve de consultar, observou proficiencia, ordem e aceio, dignos de menção. $(1899$, p. 8).

(...)

A praz-me informar-vos de que os empregados do Banco mostram no desempenho de seus encargos, com especialidade os chefes das differentes repartições, muita dedicação e interesse. (1900, p. 10)

Verifica-se aqui a diferença no teor das palavras quando se referem aos "chefes" e quando são abordados os "simples empregados": digno de louvor, mormente os Chefes, arduo, trabalhoso, grande augmento de expediente, satisfactoriamente desempenhado, zelo e aptidão da maior parte dos funcionarios, principalmente no que se respeita aos Chefes, cumprem dignamente.

Quando são mencionados os diretores, os termos são mais entusiasmados ainda. Comparemos a morte ou saída de diretores com a dos empregados (quando mencionado) (BB, 1861, 1865, 1868, 1869, 1873, 1878, 1881, 1885):

Nomeado por Decreto do Governo Imperial de 8 do corrente para o honroso cargo de Presidente do Banco do Brazil, diz-me a consciencia, senhores, que vindo occupar o logar do finado Conselheiro de Estado Candido Baptista de Oliveira, só posso trazer-vos o tributo do maior zêlo e dedicação no desempenho da ardua tarefa que me foi commettida; e que os importantes interesses confiados a este Estabelecimento deverão ressentir-se da falta dos talentos e reconhecida ilustração profissional daquelle prestimoso cidadão, cuja perda a Directoria sinceramente lamentou. (1861, p. 14). (...)

Tendo fallecido o chefe da contabilidade João Frederico Moller antigo zeloso e dedicado empregado do Banco, foi nomeado para substitui-lo o Ajudante Manoel José Madeira que tem desempenhado muito satisfactoriamente as obrigações de seu cargo. (1865, p. 17).

(...) 
No curto período do anno ultimamente decorrido aprouve á Divina Providencia chamar a si tres Directores deste Banco, o conselheiro Herculano Ferreiro Penna, José Raphael de Azevedo, e Ignacio Eugenio Tavares. As distintas qualidades que recommendavão esses cavalheiros justificão a viva saudade que todos experimentamos, assim como zelo e dedicação que consgravãoa este estabelecimento perpetuará a nossa gratidão. (1868, p. 21).

(...)

Fallecendo no principio do anno corrente o escripturario do Banco Ricardo José de Souza Proença, foi nomeado para substituilo Eduardo Maria Campos. (1869, p. 17) .

(...)

Fallecendo durante o anno do Pagador, o Reecebedor, e o Fiel da emissão do banco, Candido Duarte Silva, Torquarto Joaquim da Costa e Joaquim da Costa e Francisco José Bento de Carvalho, o que a Directoria muito lastimou porque erão excellentes empregados, forão os dous primeiros substituidos por outros d'entre o pessoal do mesmo Banco, supprimindo-se assim tres lugares, do que resultou economia para o estabelecimento.

A morte nos privou, durante o anno do concurso de quatro bons empregados. O Secretario João Martins do Amaral cujo fallecimento vos foi comunicado no ultimo relatorio, e Recebedor Antonio Gonçalves Pecego, o Porteiro Diogo Antonio de Souza e o Contínuo Francisco Antonio Mendes de Oliveira, que exercia este emprego desde a fundação do Banco, com geral estima de seus superiores. (1873, p. 28).

(...)

No decurso do anno preencherão-se três vagas dadas no pessoal do Banco, sendo duas por morte de um escripturario e um praticante, e a terceira pela demissão (...)

O pessoal da Thesouraria foi augmentado com um ajudante de pagador e outro de recebedor, para se poder fazer o expediente com mais promptidão. (1878, p. 34).

(...)

O pessoal do Banco foi modificado pelo fallecimento do $3^{\circ}$ escrpturario Joaquim Carlos de Niemeyer Junior, e pela demissão que pedio o praticante Henrique Marques Lisboa Sobrinho. Estas vagas não forão preenchidas, tendo apenas havido algumas promoções que constão do quadro respectivo.(1881, p. 8). (...)

Deu-se no quadro dos empregados do Banco a seguinte modificação: passou a Fiel Recebedor o ajudante de Recebedor Alfredo da Costa Barradas, e a Fiel Pagador o recebedor José Maria do Amaral Junior.

O 2. ${ }^{\circ}$ escripturario José Alves Chavantes pediu demissão.

O Conselho director fez o exame e conferencia dos valores pertencentes ao Banco, e dos que estão confiados á sua guarda.

Tendes de proceder a eleição de um membro do Conselho para substituir ao distincto $\mathrm{Sr}$. isconde de Tocantins que se houve com a 
maior dedicação no desempenho de seu cargo; e bem assim tendes de prover a renovação da Commissão Fiscal, a cujos dignos membros em nome do Conselho Director, tenho o prazer de testemunhar profunda gratidão pelas suas maneiras cortezes e pelo seus prudentes conselhos. $\left(1885, \mathrm{~s} / \mathrm{n}^{\mathrm{o}}\right)$

As deplorações em virtude da saída ou morte de um não-diretor são bem menores que daquele com maior grau hierárquico.

Interessante também verificar que a morte de empregados comuns em muitos casos continham substituições rápidas, com pouca ou nenhuma atenção ao finado.

Porém duas mortes, Visconde de S. Franscisco (1892) e Sousa Dantas (1894) já na República chamam muito a atenção pelo tratamento dispensado (BB, 1892, 1894) :

Já depois de entrados no actual anno bancario, era tambem roubado ao nosso affecto e á nossa veneração, o dignissimo VicePresidente do Banco - Visconde de S. Francisco, caracter austero, e cujas altas qualidades lhe grangearam não só a vossa estima como tambem a do commercio, do qual foi incontestado ornamento.

Filiado a este Estabelecimento, desde o anno de 1853, em que se operou a sua fusão com o antigo Banco Commercial, foi o finado, sucessivamente, Thesoureiro Director e Gerente da carteira Commercial, cargos em que deu longas provas de infatigavel amor ao trabalho e de admiravel tino para os negocios, assim como da mais inquebrantavel probidade.

Caracter austero alliado á mais fina amenidade de tracto, tinha o conselheiro Diogo o dom de conquistar dedicações, procurando sempre desempenhar o seu dever.

Valeu-lhe isso a externa popularidade de que gosto n'esta Capital, e em mais de um Estado da União.

Familiarisado com o nosso commercio, conhecia-lhe todas as necessidades, e tinha a intuição do remedio para cada situação.

Pelo longo traquejo dos nossos negocios, tornára-se o repositorio vivo das tradições deste Banco, e o leal conselheiro da sua administração. (1892, p. s/no (...)

O desprendimento com que geria os negocios do Banco, traduz-se nos modestos haveres que legou aos seus herdeiros, após um tirocinio de quasi 50 annos de incessante labor bancario. E' este o seu maior elogio.

Da alta estima em que era geralmente tido, deram irrecusavel testemunho as numerosas demonstrações de estima, ainda não excedidas, que recebeu durante a enfermidade, e as derradeiras homenagens prestadas ao seu sahimento, com desusada consternação. 
Logo que tive a noticia do seu fallecimento, reuni a Directoria e, depois de assignalar o motivo que nos enlutava, manifestei a falta que nos fazia o digno companheiro que deixava n'esta casa exemplo inexcedivel de trabalho e honradez, no decurso de quasi meio seculo, e o dever em que estavamos, todos, de lhe prestar as ultimas e mais significativas homenagens.

Por essa occasião resolveu a Directoria dispensar-lhe as manifestações solemnes que conheceis, pela publicidade que tiveram, inclusive a de erigir-se um mausoleu no jazigo perpetuo, para esse fim adquirido, e que se acha em adiantada execução, devendo ficar prompto até o fim do proximo futuro mez de Outubro, segundo as affirmações do artista Bernardelli, incumbido da obra.

Cabe aqui não só pela immediata connexão com o assumpto, como pelo dever de dar cabal desempenho ás vossas deliberações, transcrever a resolução que, no justissimo empenho de proclamar os serviços prestados, em bem d'este Banco, pela finado, tomastes na ultima reunião da assembléa geral. (1892, p. 10)

(...)

RESOLVE:

«2. ${ }^{\circ} \mathrm{E}^{\prime}$ auctorizada a illustre Directoria a mandar fundir em bronze o busto do mesmo benemerito conselheiro para ser collocado no salão de honra do edificio do Banco;

«3..$^{\circ}$ A presente moção será transcripta de theor na acta da presente sessão, e do mesmo modo reproduzida no Relatorio do futuro anno.

Para preencher a vaga do finado na Directoria, foi convidao,, na fórma do art. 27 dos Estatutos, o Sr. Conselheiro Manoel Francisco Correia, Presidente do Conselho Fiscal d'este Banco, e o conhecedor, por isso, de todos os seus negocios.

Tendo o seu nome ligado á alta administração do paiz, onde prestou relevantes serviços, parece, sem offensa a terceiros, que a Administração não podia fazer recahir a sua escolha em cidadão mais competente.

(...)

Começarei a menção dos factos capitaes de que tenho o dever de dar-vos conta, consignando o fallecimento do benemerito e inolvidavel brazileiro, o Conselheiro Manoel Pinto de Souza Dantas, que tanto honrou o cargo de Presidente deste instituto, de que em boa hora o investio o Governo da Republica, depois de effectuada a fusão dos extinctos Bancos do Brazil e da Republica dos Estados Unidos do Brazil.

Não poderei nem saberei traduzir-vos o immenso pezar de que sou interprete neste momento, ante uma perda de tal magnitude e que enche de luto o coração de todos os que conviveram com aquelle espirito verdadeiramente privilegiado e cuja falta é profunda e sinceramente sentida por todos os que podem devidamente apreciar a collaboração inestimavel de que ficou privado o Banco da Republica do Brazil. (1894, p. s/no).

(...) 
Ao receber a fatal noticia apressou-se a Administração em prestar á memoria do seu digno e benemerito Presidente todas as homenagens do seu respeito, da sua gratidão e da sua saudade.

No dia do lugubre acontecimento a Directoria, em sessão extraordinária, unanimemente resolveu ;

$1^{\circ}$ Cerrar immediatamente as portas do edificio do Banco e serem assim conservadas durante tres dias ;

$2^{\circ}$ Tomar luto por 15 dias ;

$3^{\text {o }}$ Autorisar as despezas do funeral, obtida a devida venia da familia do illustre finado;

$4^{\circ}$ Collocar sobre a ataúde uma grinalda ;

$5^{\circ}$ Adquirir o jazigo perpetuo, mandadno collocar n'elle singelo mausoléo de marmore;

$6^{\circ}$ Mandar celebrar missas por alma do illustre morto no setimo dia do seu passamento.

Embalsamado o cadaver do semore chorado cidadão, enquanto esteve orvalhado pelo pranto dolorido e sincero da familia e dos amigos, recebendo as mais significativas demonstrações de respeito e veneração de seus compatriotas, os representates da Directoria deste Banco tambem velaram junto aos despojos venerando até o momento em que, n'um dos mais imponentes prestivos que se tem visto esta capital, foram recolhidos á sua ultima morada. (1894, p. 4).

Nessa direção percebemos que embora o trabalho crescesse de maneira importante, o discurso acerca do trabalho dos empregados era de subestimação. Eram vistos como inferiores, como coisas inanimadas, que eram facilmente substituídas.

Adicionalmente, o banco evidenciava que o aumento do trabalho não necessariamente exigia um aumento da mão-de-obra, já que os mesmos podiam "se esforçar" (BB, 1863, 1867):

O incremento havido, durante os dous ultimos semestres, nas transacções do Banco fez augmentar igualmente o trabalho, que pesava sobre os empregados, os quaes em geral, esforçando-se por bem desempenhar os seus deveres, conseguiram sempre que não se entorpecesse a marcha dos differentes serviços que constituem o mecanismo da administração interna do Banco (grifo nosso); mostrando-se principalmente os chefes das diversas repartições recommendáveis pela sua actividade, e dedicação a bem da ordem e regularidade, que caracterizam os estabelecimentos desta natureza. (1863, p. 16). 
Não obstante o extraordinario accrescimo de trabalho que se deu durante o anno, não foi augmentado o numero de empregados, os quaes redobrando de esforços para satisfazerem as exigencias do expediente (grifo nosso) diário,muito auxiliárão, segundo fui informado, a directoria do Banco, sobressaindo alguns de entre elles pelo seu zelo e intelligencia, mórmente os chefes das diversas repartições; pelo que cumpro um acto de justiça, manifestando-lhes perante a assembléa geral o reconhecimento da mesma directoria. (1867, s/n).

Na República, o método e disciplina tomam corpo no discurso. A postura para com os empregados dá indícios de ser intimidadora e agressiva, algo bem comum nas instituições financeiras dos dias atuais (BB, 1891):

\footnotetext{
O principal, em instituições de grande movimento como a nossa, é que as repartições estejam em facil e prompta communicação com os seus chefes, para o fim da fiscalisação, e deem commodo accesso ao publico, a bem da prompta solução dos negocios. (...)

Pequenas alterações tem soffrido o pessoal do Banco proporção que os cargos vão se tornando vagos a Administração vai supprimindo os dispensaveis, no intuito de manter o pessoal ao estrictamente necessario ao serviço. (p. 3)
}

\section{Conclusão da seção:}

Verificamos nessa seção o discurso em relação ao nível hierárquico dos diversos tipos de funcionários da instituição.

O capital privilegia e serve aqueles mais próximos da classe dominante, da estrutura. Aliás e inclusive é um instrumento forte de cooptação de interesses.

Assim, no tocante aquele mais favorecido economicamente, os adjetivos são de alto calão, inclusive com lástimas e homenagens dramáticas quando da perda dos mesmos. Em relação aos funcionários de agência, aqueles desvinculados da estrutura, a postura é bem diferente, inclusive com alguns adjetivos curiosos, como "dispensáveis", por exemplo.

Como consequência, concluímos três pontos, a saber: 
Primeiramente, a criação do desejo ao capital naqueles das classes mais baixas, incentivando-os a serem algum dia melhor hierarquicamente inserido, desvirtuando-os assim do ideal revolucionário.

Podemos admitir, numa visão gramsciana, que esse discurso elitista também tem a capacidade de cooptação das massas, a fim de serem mais bem vistos pela sociedade como um todo.

Segundamente, como consequência, ocorre o isolamento maior daqueles intelectuais das classes subalternas. Ao criar nos membros da classe menor o desejo de acesso ao capital, o intelectual dessa classe encontra maior dificuldade de disseminação ideológica característica e necessária à supressão das condições repressivas de vida a que sua classe é submetida.

Em terceiro, como efeito contrário ao primeiro ponto, esse mesmo discurso elitista, totalitário e antidemocrático, corroboramos com Viotti da Costa (2010), pode ter a capacidade de inibir aqueles mais distantes da estrutura de buscar maior acesso a condições financeiras de vida melhores, justamente em virtude do caráter do discurso e da pressão por eles sofrida. 
3.1d - A questão dos meios de produção: o trabalho escravo

O Brasil manteve sua escravidão como sistema legal até 1888. O escravo era tido como um dos fatores de produção, como coisa, como posse, como animal. Uma posse de seu senhor.

Nessa seção, objetivamos verificar qual a tratativa dispensada em discurso em relação ao negro e sua relação com a ideologia muitas vezes preconceituosa em relação a essa classe, com efeito inclusive nos dias atuais.

Nos anos anteriores à lei Áurea, o Banco se preocupava deveras com uma das principais garantias de sua carteira hipotecária (BB, 1886, 1887):

Bem que seja dificil estimar na actualidade as garantias de lavoura, em consequencia da depreciação n'ellas havida, mormente na que se refere ao braço escravo (grifo nosso), ainda assim pelo conhecimento de cada devedor e do estado de prosperidade maior ou menor de cada um, para reducção que apresentão os saldos de cada contracto, é opinião da gerencia que dos Rs. 24.062:442\$920 emprestados á lavoura, Rs. 16.089:090\$540 estão em mão de devedores que têm recursos para solver seus debitos de capital e juros, quando não dentro do prazo restrito de seos contractos, com a dilação de um - dous - tres annos a mais.

Se é certo que a garantia real soffre depreciação hoje, não é menos certo que ella possa melhorar amanhã, e quando se trata de uma instituição que não morre, o tempo é um elemento com que se deve contar (grifo nosso). (1886, p. 20).

Em execução da Lei n ${ }^{0} 3270$ de 28 de Setembro de 1885, expedio o Banco em Março de 1886 circular a todos os devedores hypothecarios recommendando-lhes que porcedessem á matricula dos seus escravos e até $\mathbf{3 0}$ de Setembro remettessem os documentos originaes, ou certidões authenticas. (grifo nosso) Bem poucos cumpriram em tempo esse preceito, de sorte que em 12 de Janeiro de 1887 foi expedida nova circular, sendo preciso no decurso do mez de Março, que o Banco pusesse em actividade advogados de diversas localidades ou para proceder á matricula ou para verificar a existencia d'ellas nas Collectorias.

Por esse meio ficou a Administração certa de que tinham sido matriculados todos os escravos, nas condições de o serem, embora até esta data não possua todas as matriculas ou certidões, acchandose por isso privada de apresentar as relações dos escravos e seus valores, como sempre tem feito. (1887, p. 17 e 18). 


\section{(...)}

Desde 1884 cessarão as operações regulares da carteira hypothecaria e sómente por cepção e para garantia de operações de outra natureza se tem realisado algumas. Sem parar na analyse das razões, que determinaram esta resolução, é rigoroso affirmar que, presente estado de cousas, falta a base indispensavel a taes operações, a apreciação do valor da propriedade - avillado por perturbações de tal ordem que, a continuarem chegarão a constituir o empobrecimento geral da mais importante e quase exclusiva industria do Brazil. (grifo nosso)

Sobre todos os elementos de desmoralisação, a ausencia do credito destruio a base sobre que teria de assentar o plano de reoganisação da lavoura, e emquanto cumpria aviventar as energias dos agricultores, tudo tem concorrido para lh 'as abater, abandonando-os no declinio em que a maior parte já nem pensa em reagir.

Esta deploravel situação carece de remédio ; a lavoura é e será no futuro a industria natural do Brazil e a fonte de sua riqueza ; avigora-la, rodea-la dos elementos que possão produzir a sua restauração deve ser empenho geral e ao Banco do Brazil cumpre dar o seu contingente a esta empreza meritoria.

Se os seus interesses não aconselhão a manutenção do regimen que adoptou, de accordo com o governo imperial, outros meios haverá de manter uma instituição sem a qual podemos perder a esperança de que se fortaleça a riqueza agricola, antes teremos a certeza da sua progressiva decadência (grifo nosso). (1887, p. 8).

A questão da abolição dos escravos é também um ponto muito curioso na maneira em que é contada: em nenhum momento se comenta das atrocidades cometidas, ou das injustiças. (BB, 1888):

Se considerarmos o atrazo de uma até tres prestações em contratos hypothecarios, mórmente depois de um anno de falha de café e quando entramos em anno de abundancia, embora cercado de outras difficuldades, causadas pelo acto de abolição (grifo nosso). (p. 16).

São tratados como fatores de produção inanimados, como matéria-prima. Percebemos que a abolição causou dificuldades, não resolveu injustiças. Além disso criou um grande problema para o Banco do Brasil que tinha em suas mãos nada mais que 19.650 escravos hipotecados, com valor superior a 12 mil contos. (BB, 1888): 
Depois da lei de 13 de Maio ainda procedeu o Banco a differentes sequestros, uns a pedido dos devedores, outros por estar informado que aos mutuarios faltavam recursos para pagar salarios, tendo-se retirado os libertos.

Como simples informação estatistica achei conveniente consignar nesse relatorio que ao decretar-se a extincção da escravidão existiam hypothecados ao Banco 19.650 escravos, representando, segundo a tabella que deu execução á lei n. 3270, de 28 de Setembro de 1885, em um valor approximado de RS. 12.000.000\$000 (grifo nosso). (p. 18)

E como tratar contabilmente? (BB, 1888):

É evidente que o desapparecimento desta garantia deve em alguns casos acarretar prejuizo para o Banco (grifo nosso), por emquanto porem não é possivel avaliar a que somma se elevarão taes prejuizos. (p. 18).

Se são libertos (e de propriedade do banco), o valor é zero. Solução: lançar a despesa ou renegociar com os devedores as garantias.

Já no ano seguinte, é evidenciado (BB, 1889):

Continuarão a actuar este anno os effeitos da grande revolução social terminada pela lei de 13 de Maio de 1888, que extinguiu a escravidão no Brazil. $O$ abalo que soffreu a lavoura, principal factor da nossa riqueza, e com ella todos os outros interesses da sociedade, naturalmente solidarias, tem transparecido nos nossos balanços fazendo avultar a verba “titulos em liquidação (grifo nosso). (p. 5).

O interesse do grupo dirigente confundido com o geral: mais uma vez, a questão do término das relações injustas e cruéis com os africanos e seus descendentes é tratada como um abalo, uma anomalia, que precisava de medidas drásticas para restabelecer "todos os outros interesses da sociedade" e o "principal factor da nossa riqueza." (BB, 1889): 
Mas, como para os grandes males são necessarios grandes remedios, de ha um mez a esta parte a estação promette correr bem e o Governo Imperial convencido de que a lavoura tinha direito a uma grande reparação, effectuou contractos com diversos Bancos e auxiliou a creação de outros, para que estes emprestassem a prazo largo e juro modico aos lavradores que apresentassem garantias reaes ou pessoaes.

Estas medidas não podiao deixar de produzir promptos effeitos. É assim que muitos dos desanimados creàrão coragem, e todos a uma parecem cheios de confiança no futuro, podendo-se affirmar que a terra já começa a valorisar-se e dentro de tres ou quatro annos os effeitos da lei de 13 de Maio, terão desapparecido como o das chuvas de pedra que assolão as lavouras de tempos a tempos. (grifo nosso) (p. 19)

Agora a comparação do fim da escravidão com uma chuva de pedras (BB, 1889):

Ainda assim devemos aqui assignalar (...) na qual o desapparecimento do braço escravo tornou imprestável a terra e o cafesal gasto (grifo nosso). (p. 20).

Mesmo após alguns anos da abolição, a menção à catástrofe social ainda é presente (BB,1892, 1902):

Posteriormente, tendo a lei de 13 de Maio annullado o valor de parte importante da garantia, sobre que repousavam taes contractos, pareceu fundado o receio de que sua liquidação seria difficil, lenta e prejudicial.

Felizmente, não se realisaram taes apprehensõoes, graças á vitalidade da lavoura, que assentava antes na fertilidade do solo, do que no valor do braço servil (grifo nosso). (1892, p. 28).

(...)

O resultado, porém, d'este succinto balanço de lucros e perdas, procedentes da liquidação verificada, demonstra que o Banco não tem auferido dos auxilios prestados á lavoura vantagens reaes, que pudessem induzil-o a acceitar novos accôrdos com o Governo; mas que só os realizou para corresponder ao apello feito a seus sentimentos de patriotismo pelo mesmo Governo, que se manifestava então empenhado em debellar a crise do trabalho, com que luctava a lavoura (grifo nosso). (1902, p. 27) 
Conclusão da seção:

Nessa seção verificamos o tratamento dispensado em termos de discurso a questão dos escravos e a abolição dos mesmos.

Vistos como mercadorias, como coisas, o fim do respectivo regime em nosso país foi visto como uma aberração, com consequencias claras para os detentores da estrutura, que teriam seus lucros cada vez mais dizimados, com a crise da abolição, comparadas, inclusive, como vimos, a "uma chuva de pedras".

Aqueles detentores dos meios de produção, inclusive escravos, viam suas garantias perdidas, viam seus custos estimados de produção provavelmente aumentar com a necessidade do trabalho assalariado, viam o país a beira de uma superprodução cafeeira, assim como colocado por Netto (2009), previam o colapso de sua riqueza, confundida com aquela do país.

A ideologia em relação ao escravo nada mais era que a superestrutura necessária à estrutura vigente. 


\section{2 - INTERFACE ENTRE SOCIEDADE CIVIL E SOCIEDADE POLÍTICA NO SEIO DO ESTADO BRASILEIRO}

$\mathrm{Na}$ presente seção (3.2), vamos abordar a interação entre a sociedade civil e sociedade política brasileiras no seio do Estado brasileiro mais especificamente no tocante às (3.2a) ao interesse final da instituição, em especial em relação às operações efetuadas entre o Banco do Brasil e o Poder Político, (3.2b) a questão das revoltas populares, destacadamente aquelas ocorridas nos anos primeiros da república e por fim estudaremos a (3.2c) transição do poder político brasileiro, desembocada com a Proclamação da República aos 15 de Novembro de 1889 e posteriormente, em 1894, com a queda do gabinete militar para o civil oligárquico, em que são verificados os conflitos entre os intelectuais tradicionais e os orgânicos, bem como o alguns elementos que podem (ou não) indicar o reajustamento do bloco histórico nacional. 
3.2a - Interesse público ou privado: operações e troca de favores entre o banco e o(s) governo(s)

Desde sua fundação, o Banco do Brasil era pensando para agir em prol do bem público, visando o desenvolvimento do país como um todo. Verificamos no Referencial Teórico que o mesmo era uma instituição privada, societariamente, porém com grande importância governamental nas suas decisões.

Todavia, o interesse que sobrepujava as ações e o discurso era ambíguo, já que misturava a causa pública com a consequência privada. Isto é, apenas nas palavras dispendidas o uso e a ação era em benefício do público, porém, as políticas foram em prol único de dois grupos: governo e detentores dos meios de produção, incluindo-se nesses últimos os acionistas, representantes maiores do capitalismo em sua dinâmica financeira.

O objetivo dessa seção, pois, é entender como o Banco do Brasil (representante da sociedade civil) foi ferramenta de orientação ideológica, levando em consideração o conceito de Estado Ampliado (Gramsci, 1999), dadas as suas relações com os diversos tipos de governo que vivemos.

Na segunda metade do século XIX, começou-se a assistir em território nacional um debate acalorado sobre a unicidade ou pluralidade de emissão bancaria causados pela grande problemática do câmbio fixado pela Lei de 11 de setembro de $1846^{12}$, sendo a primeira vertente encabeçada pelo Visconde de Itaboraí que retoma seu cargo de presidente em 1855 e a segunda, liderada por Irineu Evangelista de Souza, o Barão de Mauá, que era um dos diretores eleitos do BB. Esse manifestou seu descontentamento, demitindo-se do cargo, fundando conseguintemente, a Casa Mauá, com a razão social de Banco Mauá, Mac Gregor \& Cia em 1854, com vistas à tentativas reais de emissão $(\mathrm{BB}, 2010)$. A reação do Banco do Brasil foi direta e rápida, solicitando ao Imperador providências, que prontamente foram atendidas: “proibiu as sociedades em comandita de dividir seu capital em ações.” (p. 32).

\footnotetext{
${ }^{12}$ Que na verdade transferia o ônus da variação cambial para o Estado (para o Banco) em detrimento dos reais detentores desses riscos, que são em sua esmagadora maioria os inúmeros e crescentes proprietários de fazendas cafeeiras do Sudeste brasileiro).
} 
Uma prova primeira da ligação entre a sociedade política e a sociedade civil, a "velha nova" junção do público com o privado. Atende os interesses do Governo Imperial e dos acionistas, ávidos pelos gordos dividendos proporcionados pela máquina Banco do Brasil.

Tudo isso apoiado pelo contrato social estabelecido com a sociedade que confere esses direitos aos detentores do Estado. Apenas propiciando elementos para aumentar o monopólio do banco em um mercado ainda incipiente mas com previsões gigantes de crescimento (como o Brasil, o eterno país do futuro...).

Nessa mesma linha de raciocínio, vejamos mais um exemplo ocorrido no ano bancal de 1858 (BB, 1858):

A creação de hum novo Banco de circulação nesta Cidade com a faculdade de estabelecer Caixas Filiaes na Província do Rio de Janeiro, tendo o direito de emittir bilhetes de valor mínimo de Rs. $10 \$ 000$ collocando deste modo a circulação do Banco do Brasil em posição desvantajosa, por isso que lhe he unicamente permittida, na mesma Província, a emissão de notas de valor mínimo de Rs. 20\$000. Levou a Directoria a dirigir aos Poderes do Estado huma representação pedindo-lhe faculdade idêntica á do novo Banco. Esta representação levada ás Camaras Legislativas nos ultimos tempos da sessão passada não foi ainda tomada em consideração: espera, porém, a Directoria que o Corpo Legislativo á vista das obrigações de elevado alcance contrahidas pelo Banco com a Nação, não lhe negará os meios de desempenhal-as cabalmente, permitindo-lhe a faculdade pretendida (grifo nosso). (p. 5)

Os lucros e fartos dividendos evidenciam essa "posição desvantajosa" do Banco do Brasil. O argumento soa interessante "á vista das obrigações de elevado alcance contrahidas pelo Banco com a Nação".

O Banco do Brasil devido a grande falta de moeda em circulação em nosso país e aproveitando-se da sua ligação com as classes abastadas, os grandes fazendeiros, e também a incipiente pequena burguesia brasileira, já completamente dependente da produção cafeeira, efetua nesses três primeiros anos uma enxurrada de empréstimos, acusadas algumas vezes pela mídia da época e por vozes dissidentes como irresponsável, no mínimo, como o Jornal de Commercio nos anos de 1850 e 1860. (BB, 2010). 
Nessa direção, segundo BB (2010), o fluxo de emissões do Banco do Brasil “aproximava-se perigosamente do seu teto legal, que era o dobro do fundo disponível (...) Mas o próprio presidente do Banco (...) declarou que não havia motivo para receio (...) pois era uma circunstância transitória que qualquer dia despareceria pela marcha natural das coisas." (p. 33).

Mas...(BB, 1858):

A crise nas Praças dos Estados Unidos, e ramificada ás de Londres e Hamburgo, com as quaes se acha esta intimamente relacionada, devia produzir fortes abalos ao nosso commercio de importação e exportação, collocando aquelle na posição crítica de avultadas remessas, e este na impossibilidade de fazer transacções com os productos do Paiz, por falta de compradores convenientes nos mercados seus consumidores. $\mathrm{O}$ estremecimento do cambio, thermometro daquela operações, era consequencia inevitavel.

O Banco do Brasil sendo na Praça o unico reservatorio de capital monetario para a satisfação do commercio exterior, devia ser o primeiro a soffrer os resultados daquelles acontecimentos. $\mathrm{O}$ seu fundo disponível foi seriamente ameaçado, e de facto dentro de 10 mezes este fundo soffrera o desfalque de Rs. 4.714.123\$847 desfalque que promettia augmentar rapidamente pelos pagamentos forçados de recambios, e pedidos de remessas por parte dos credores nas Praças em crise. (p. 7)

Porém a história no conta que "essa marcha natural das coisas" não ocorreu como o previsto: dessa maneira, foi solicitado ao governo imperial, segundo BB (2010) a elevação da emissão até o triplo do fundo disponível e ao quádruplo posteriormente...(p. 33). Os dados de 1858 elucida a questão (BB, 1858):

Se pois a Directoria do Banco por hum lado estava na rigorosa obrigação de resguardar seu fundo disponivel, por outro lhe sobravão desejos de auxiliar o commercio, que em occasiões identicas luta com graves embaraços pela subita retirada de capitaes que o auxiliavão, e pela estagnação completa dos productos de exportação.

Tão ligados porém são esses dous termos, quando se trata de hum Banco de circulação, que a Directoria devia simultaneamente tratar de ambos, e por conseguinte:

Elevar a taxa de descontos.

Favorecer a satisfação das necessidades do commercio externo. Servir liberalmente as do commercio interno. (p. 8). 
E assim o fez: elevou a taxa de juros e serviu liberalmente a Corte. O Relatório de 1857 e de 1858 elucidam a questão do aumento da taxa de juros cobrada pela instituição, mesmo com todo o crescimento dos lucros e com o aporte generoso dos fundos do Thesouro Nacional, assim como narrados nesse mesmo Relatório. O intuito: mais lucro e dividendos para os acionistas, obviamente (BB, 1857):

Nestas medidas se comprehende a elevação da taxa do juro de 8 a 9 por cento, a primeira vez em 27 de Novembro de 1856, e a segunda em 6 de Maio do corrente anno. (p. 4).

E também no ano seguinte, primeiro com o aporte do Thesouro, o que permitiu segundo o Banco, uma redução na taxa de juros, devido ao recurso recebido (BB, 1858):

Além disso o Poder Legislativo havia autorizado o Governo a depositar no Banco do Brasil os saldos do Thesouro, que montavão a cerca de cinco mil contos de réis: e posto que não estivessem elles ainda recebidos nenhuma intenção tinha a Directoria de recusal-os. Em taes circumstancias a reducção da taxa era huma necessidade, e a Directoria assim o resolveo.

Nesse estado foi ella conservada até 15 de Dezembro, época em que tornando-se mais forte o receio, que levára a Directoria á elevação da taxa em Maio; isto he, a exportação do capital monetario par fora desta Praça, resolveo eleval-a a $10 \%$, e mais tarde a $11 \%$, acompanhando esta medida de outras que o caso exigia, e a ella pareceo convenientes. (p. 5-6)

Nesse mesmo período, mais uma grande lição da ligação entre a sociedade política e civil. Uma operação entre o Banco e a Corte (BB, 1857):

Em virtude da deliberação tomada pela Directoria de descontar em quanto lhe permitisse o estado da Caixa, letras da Thesouraria Provincial do Rio de Janeiro, até a quantia de 1.000.000\$, como no ultimo Relatorio foi trazido ao vosso conhecimento, tem aquella Thesouraria preenchido a mencionada quantia de $1.000 .000 \$$, pela qual figura como devedora ao Banco. Esta somma foi descontada com a differença de taxa de $2 \%$. (p. 8 ). 
Vemos que se tratava de um empréstimo bem generoso, já que somada ao diferencial do spread cobrado, no Relatório de 1858 este não fora amortizado nenhum centavo (ou conto) e concedido mais um "benefício extra" de 300:000\$000 (BB, 1858):

Durante o anno conservou-se no mesmo estado o emprestimo feita á Thesouraria da Provincia do Rio de Janeiro, sendo a sua importancia de Rs. 1.000.000\$000, e o juro de 2\% menos que a taxa geral. Além desta quantia se fizerão a pedido da Administração Provincial descontos de bilhetes seus com o abatimento do estilo, que tem sido de $1 \%$, achando-se hoje a responsabilidade da Thesouraria por estes titulos para com o Banco reduzida a 300 contos, além dos 1000 já referidos. (p. 10).

Se verificarmos bem, o funding recebido do Tesouro seria razoável para a diminuição das taxas de juros e para a dinamização de empréstimos para classes menos favorecidas. Porém, o que ocorreu? "Apenas" $20 \%$ do capital recebido foi devolvido à Corte, com uma taxa de juros subsidiada e com pagamentos quase sem previsão, já que até a análise feita, nenhuma amortização fora feita.

E o efeito para os demais? Um aumento da taxa de juros de $8 \%$ para $11 \%$ a.a.

Em muitos relatorios são descritas, de maneira bem simples e direta as relações financeiras entre banco e governo (BB, 1863, 1864, 1865):

As operações que tiveram lugar durante o anno bancario, directamente com o Thesouro Nacional, importaram em 15.419:000\$000 (...) (1863, p. 14).

(...)

As operações effectuadas no decurso do anno bancario, directamente com o Thesouro Nacional importárão em 18.176:000\$000 (...) (1864, p. 11)

(...)

As operações directamente effectuadas com o Thesouro Nacional, importárão durante o anno bancario findo em 30 de Junho em 13.654:000\$000. (1865, p. 11). (...)

Com a Provincia do Rio de Janeiro, importárão as operações feitas durante o mesmo periodo por letras descontadas em 2.112:904\$700. $(1865$, p. 12) 
Com esse alarmante cenário, de fornecimento de capital de maneira desvairada são narradas as constantes correspondências entre o Banco e o Governo Imperial, que mesmo devido aos laços estreitos, continham, também, suas discordâncias (BB, 1858):

Reconhecendo, porém, que por si só não poderia conseguir todos os resultados que visava, principalmente no tocante aos dous últimos, recorreo aos Poderes de Estado, dirigindo ao Exm. Ministro da Fazenda os Officios 1 e 2.

(...)

A estes Officios deo o Governo Imperial as respostas (...) pelas quaes se convenceo a Directoria de que as medidas propostos ficavão adiadas para occasião oportuna, e por conseguinte impossibilitada desde logo de ocorrer ás necessidades urgentes do momento, como desejava.

(...)

Com este officio terminou a correspondencia havida entre o Governo e o Banco a tal respeito; porque o Governo não se dignou responder se aceitava ou não os serviços postos á sua disposição pela Directoria.

(...)

Da fiel narração dos factos durante o periodo decorrido de Dezembro a Março, deveis reconhecer que se a Directoria do Banco não prestou ao commercio exterior todo o auxilio que desejava, concorreo de alguma sorte para tornam menos dolorosa a sua posição, facultando os saques de Dezembro a Janeiro na importancia de Lgst. 350.000 (...). (p. 5-6)

Dissidências entre o privado e o público? Talvez não... O Offício 4 do Governo para o Banco datado de 4 de dezembro de 1858 (BB, 1858):

(...) cumpre-nos responder a V. Ex, que merecendo a mais séria attenção do Governo Imperial as considerações de V. Ex., e sendo sua formal intenção prestar ao Banco toda a coadjuvação indispensável para se conservar o câmbio sobre Londres nos termos da Lei de 11 de Setembro de 1846, e salval-o da crise de que he ameaçado, de qual resultaria graves embaraços ao commercio e industrias do Imperio, está resolvido a autorizar o mesmo Banco para elevar até ao quadruplo do fundo disponível (...) (p. 6). 
Além disso, o Officio 5 de 15 de dezembro de 1858 do Augusto Imperador complementava (BB, 1858):

(...) Remetto á V.S. para seu conhecimento cópia do aviso que dirijo nesta data aos Agentes Brazileiros nessa Praça (Londres), a fim de que, sciente da intenção do Governo Imperial de que os saques do Banco do Brazil sobre o Union Bank até o valor de Lstg. 100,000 sejão pagos por conta do Thesouro Nacional no caso previsto no mesmo Aviso, faça V.S. o que estiver da sua parte e fôr preciso para que esta deliberação seja fielmente cumprida. (p. 6).

Em 1860 constam algumas medidas do Banco para sanar a situação (BB, 1860):

Se comparardes, Senhores, estes algarismos com os que vos foram apresentados nos anteriores relatorios, reportando-os especialmente ás épocas de maior movimento commercial e expansão do crédito, vereis que a Directoria do Banco, consultando devidamente $o$ interesse publico e a conveniencia do proprio Estabelecimento, procurou reduzir cautelosamente a massa das suas transacções, no intuito de habilitar-se para auxiliar mais efficazmente o commercio e as industrias do paiz com o seu credito, logo que as operações, de indole puramente mercantil, hajam recobrado a sua actividade normal (grifo nosso). (p. 8).

Nosso argumento é de que o "interesse publico" e a "conveniencia do proprio

Estabelecimento" não são tão factíveis no Banco do Brasil.

E a ajuda mútua entre Império e Banco aumenta de proporção, já que (BB, 1860):

De 1 de Julho de 1859 a 30 de Junho do corrente anno, importaram em 5.348:146\$926 as operações effectuadas pelo Banco do Brasil com o Thesouro Nacional, sendo pela maior parte saques tomados pelo Banco a favor de suas Caixas Filiaes.

Folgo nessa occasião de poder assegurar-vos, que este importante serviço tem sido prestado pelo Banco com a devida pontualidade, e sem ônus alguns para o Thesouro Nacional, no intuito de assim preencher um dos seus fins especiaes de creação.

Da conformidade com o disposto no art. 60 dos Estatutos do Banco, solicitou a Directoria ao Governo Imperial a prestação da sua garantia pelos créditos que houvesse ella de negociar na Praça de 
Londres, até a importancia de sete mil contos, valor do papel moeda resgatado pelo Banco até aquella época.

(...)

Com esta providencia tomada muito opportunamente, acha-se o Banco sufficientemente preparado para renovar o pagamento de suas notas em ouro, logo que o curso do papel circulante, e o estado do commercio o permittam, sem o risco de comprometter gravemente a conservação de seu fundo metallico. (p. 14).

Abaixo, verificamos uma análise da importância dos recursos recebidos do Thesouro, sendo explicado (BB, 1858):

O movimento progressivo destas duas verbas (...) he devido em grande parte ao deposito dos saldos do Thesouro e á elevação do juro pago pelo Banco aos particulares na razão de $2 \%$ menos que a taxa de seus descontos.

Como sabeis, achando-se o Governo autorisado pelo Poder Legislativo para depositar os saldos do Thesouro no Banco do Brasil, não podia a Directoria deixar de aceital-os contractando com o Governo, por isso que não somente procuraria interesse para os accionistas do Banco, como recolhendo a sua emissão, representante desses saldos, se collocaria na vantajosa posição de melhor regulara circulação do mesmo Banco, vantagem por si só bastante, para determinar este acto quando mesmo nenhum interesse dahi lhe proviesse. - A Directoria compraz-se porém em afirmar-vos que as sommas recebidas a premio tanto em conta corrente como por letras, concorrerão para o augmento dos interesses do Estabelecimento, sem que a sua faculdade emissora fosse ampliada.

As condições do contracto entre o Thesouro e o Banco são annexas sob n. 19 e nelas encontrareis o modo pelo qual a Directoria entendeu dever resguardar $s$ interesses do Banco harmonisando-os com os do Thesouro Nacional (grifo nosso). (p. 14).

Um trecho chama a atenção, após o recebimento da quantia do Thesouro: “(...) não podia a Directoria deixar de aceital-os (...) por isso que não somente procuraria interesse para os acionistas (..) mesmo quando nenhum interesse dahi lhe proviesse." (p. 14). Com o spread praticado pelo Banco, esse capital auxilia com uma média anual de 500:000\$000 que são livres de impostos e transferidos quase na sua completude para os acionistas.

A tônica da problemática continua a mesma no transcorrer dos anos $60(\mathrm{BB}, 1865)$ : 
Essas medidas, exigidas pelas circumstancias em que se achou o Banco por occasião da crise que se manifestou nesta praça a 10 de Setembro do anno passado, consistem na faculdade que lhe foi concedida de elevar a sua emissão além do duplo do fundo disponível, na suspensão do troco metalico das notas emittidas pelo Banco, e no curso forçado dado por enquanto, ás mesmas notas. (p. 5)

(...)

(...) agravára de instante a instante, a intensidade do mal e que colocada a Directoria do Banco entre duas necessidades oppostas, a de prestar auxilios ao commercio, a que faltavão de subito todas as fontes e recursos de credito, e a de ocorrer ao pagamento de suas notas, cuja demanda crescia nas proporções com que lavrava o panico, erão aquellas medidas naturalmente indicadas como capazes de melhorarem a situação, acalmando a agitação e serenando os espiritos; e foi sem duvida attendendo a estas ponderosas considerações apresentadas pela Directoria do Banco que o Governo Imperial em sua sabedoria julgou conveniente expedir os decretos ns. 3306 e 3307 de 13 e 14 de Setembro de 1864. (p. 6).

Veremos mais a frente que a ordem dos fatos não mudam, já que os interesses do Banco "harmonisados" com o do Thesouro são explicitados pela farta distribuição de benesses às classes abastadas e ao Governo.

Exemplos disso estão contidos no Relatório Anual de 1862, 1863, na questão da taxa de juros para os diversos stakeholders (BB, 1862, 1863):

A taxa de desconto regulou de 9 por $\%$ e 10 por $\%$ para todos os titulos commerciaes em geral, sendo de 10 por $\%$ e 11 por $\%$ para as cauções de Apolices e acções de Companhias, e de 8 por \% para as letras do proprio Banco, e do Thesouro Nacional negociada diretamente. (1862, p. 10)

(...)

A taxa dos descontos oscilou entre 9 e 11 por \% para todos as letras da praça, 9 a 12 por \% para as caucionadas, e $8,81 / 2$ e 9 por $\%$ para as letras negociadas directamente com o Thesouro Nacional e Thesouraria Provincial; resultando uma media de 9,75\%. (1863, p. $10)$.

Vemos aqui mais uma relação interessante, já que o Thesouro tinha o direito de negociar suas taxas diretamente com o banco, geralmente a um termo bem mais baixo que aqueles dispendidos para as demais classes (BB, 1862): 
Havendo o Banco cumprido com a obrigação imposta pelo art. 56 S1.o de seus Estatutos ${ }^{13}$, retirando da circulação 10.000:000\$000, e devendo proceder ao resgate de mais 2.000:000\$000, em cada anno subsequente, em data de 6 de Novembro do anno passado, assignou com o Thesouro Nacional, um convenio no qual se estipulou que o Banco entraria com a somma de 1.000:000\$000, até 31 de Dezembro ultimo, e com os outros 1.000:000\$000, até o fim de Junho de 1862, recebendo em pagamento Apolices da Divida Publica geral do Imperio de 6 por $\%$ ao preço de 93 por $\%$ o que em tempo competente effectuou recebendo 2150 Apolices e $500 \$ 000$ em dinheiro. (p. 12).

Notamos inclusive a discussão no aspecto do resgate de papel-moeda (BB, 1866):

Não tem continuado o resgate do papel moeda. Encontrando a directoria difficuldade em acha-lo, officiou, na fórma do art. 59 dos estatutos, ao governo em data de 12 de novembro de 1864, expondo respeitosamente o que occorria, e pedindo as providencias que o governo entendesse em sua sabedoria as mais apropriadas para remover o embaraço. Este officio ainda não foi respondido. Vós sabeis que o que o governo devia ao Banco relativamente ao resgate realizado anteriormente, além das quantias mencionadas no art. 2. $.^{\circ} \S 1 .^{\circ}$ e art. $4^{\circ}$ da lei de 5 de julho de 1853 , fornecidas pelo Banco, a titulo do emprestimo, sem juro, emquanto durar o privilegio do Banco, fora pago em apólices da divida publica ao preço do mercado de $93 \%$ em 27 de novembro de 1861 e 28 de junho de 1862, sendo taes apólices, como vós igualmente sabeis, vendidas pelo Banco gradualmente, sendo a ultima venda feita em 23 de maio de 1863. (p. 12).

Além disso, o ordenamento a fim de sanar a questão do meio circulante, com a transferência de recursos produtivos para o Estado, ao invés dos demais membros da sociedade $(\mathrm{BB}, 1863)$ :

Achando-se a emissao circulante do Banco em fins do anno passado, á ponto de aproximar-se o seu limite legal, em relação ao fundo disponivel; e não estando por isso o Banco habilitado para fazer frente aos descontos ordinarios dos titulos da praça, e satisfazer ao mesmo tempo ás urgentes necessidades do Thesouro nessa quadra, sem transpor o limite legal da sua emissão; julgou a Directoria necessário levar ao conhecimento do Governo Imperial 
os embaraços em que se achava, solicitando ao mesmo tempo, no intuito de os remover, a concessão da faculdade permittida pelo art. 63 dos Estatutos, nos termos em que já fôra feita pelo Decreto de 5 de Fevereiro de 1856, afim de elevar a emissão autorizada pelo art. 16 dos seus estatutos, até o limite do triplo do fundo disponivel, não só como um recurso regular, e efficaz para o fim acima indicado, como principalmente para manter por esse meio, permanentemente o necessario equilibrio entre a circulação de suas notas e a sua reserva metalica.

Entretanto que aguardava a Directoria a solução do que representara ao Governo Imperial, repondeo este em aviso de 7 de Fevereiro ultimo, adiando a concessão pedida pelo Banco (Documento n. 4), a qual se verificara todavia em 28 desse mesmo mez pelo Decreto $\mathrm{n}$. 3054 dessa data (Documento n. 5) sob condições, á que o Banco julgou dever fazer algumas ponderações, as quaes deram em resultado a revogação do mencionado Decreto, por outro expedido em data de 16 de Março ultimo, (Documento n. 6). Havendo porém a Directoria do Banco representado ao Governo Imperial os graves inconvenientes de restringir de prompto a sua circulação, para trazel-a ao limite legal, que transpuzera momentaneamente por motivos justificados, e com pleno conhecimento do mesmo Governo Imperial, foi ella devidamente attendida, recebendo em resposta o aviso de 19 de Março passado. (Documento n. 7).

Depois dos factos relatados, bem depressa restabeleceo o Banco o estado legal da sua emissão circulante, mediante as oportunas remessas de metaes, que por determinação da Directoria, lhe foram feitas de Inglaterra.

Representando o credito aberto e garantido em Londres pelo Governo Imperial, a favor do Banco do Brasil, o valor de 7.000 contos ou 787,500 libras, como no ultimo relatorio vos informei, e havendo o Banco já completado o resgate dos 10,000 contos de notas do Thesouro, a que se obrigará pelo art. 56 dos seus Estatutos, solicitou a Directoria do Governo Imperial a ampliação da referida garantia ao credito complementar de 3,000 contos, ou 337,500 libras, o que lhe foi concedido (Documento n. 8), representando assim o credito aberto pela somma dos 10,000 contos o valor esterlino de 1,125,000. (p. 7).

Percebe-se aqui a troca de favores entre o Banco e o Governo; enquanto um fornece recursos, através de empréstimos efetuados ao Thesouro e à Corte, da compra de apólices da dívida pública; o outro, tem a seu favor créditos abertos no estrangeiro a fim de trazer mais benefícios à instituição e seus principais clientes, os exportadores de café.

Interessante o trecho do Relatório de 1863, em que aborda os "supremos favores do Estado" (BB, 1863): 
Pondo aqui termo ás informações que tenho de dar-vos, como orgam official da Directoria, á cujo zelo e intelligencia haveis confiado a gestão do primeiro estabelecimento de credito do nosso paiz, me permittireis ainda, senhores, que eu chame a vossa atenção para o acurado exame dos factos relatados, cuja apreciação vos fará conhecer o estado regular, e direi mesmo satisfactorio em que se acha actualmente o Banco do Brasil (fallo da caixa Matriz); e mau grado os conhecidos embaraços que até o presente tem perturbado a sua marcha, não hesito de assegurar-lhe um futuro lisongero, continuando elle, como espero, a trilhar o caminho traçado pela prudencia, que o levará sem duvida com o favor dos Supremos Poderes do Estado, a collocar-se em uma situação normal, caraterisada pela consolidação do seu credito, e pelo cabal desempenho dos importantes fins de sua creação (grifo nosso). (p. 17).

Porém a Guerra do Paraguai requeriu muito do numerário brasileiro a fim de cobrir os gastos de guerra.

E nesse sentido, transcrevemos a representação efetuada pelo Banco do Brasil ao Governo Imperial e a Câmara em 1866 (BB, 1866):

Com o mais profundo respeito vem a directoria do Banco do Brasil patentear a esta augusta camara os perniciosos effeitos que para o commercio, a lavoura e mais industriais do paiz, e para os interesses dos accionistas do mesmo Banco, devem resultar das medidas propostas pelo Exm.Sr.ministro da fazenda a esta augusta camara em sessão de 9 do corrente mez (grifo nosso) (...) das providencias extraordinárias que a sabedoria do governo julgou conveniente então adoptar, e ás quaes com justa razão o projecto em seus fundamentos atribue á situação anormal da circulação fiduciaria.

Manifestada a crise em 10 setembro de 1864 pela suspensão de pagamento da mais importante casa bancaria (...). N'estas circumstancias se o Banco do Brasil, apreciando superficialmente a situação, cuidasse tão sómente dos seus proprios e immediatos interessses poderia, aos olhos de muitos, ter cortado as difficuldades com que actualmente se luta. Para isso não tinha a directoria mais do que cruzar os braços, suspender immediatamente as operações de descontos, ir deixando vencer os titulos de sua carteira e satisfazer o pagamento das notas que se apresentassem ao troco. Os recursos que então possuía o Banco, asseguravão o exito d'este procedimento, profícuo unicamente quanto ao augmento da emissão.

Mas, se tal fora em tão grave conjuctura a norma de proceder do Banco do Brasil; se em presença da maior crise que tem desabado sobre a nossa praça tivessse o primeiro estabelecimento de credito do paiz assumido uma posição 
meramente negativa de abstenção e indiferença, com razão se teria clamado, e se clamaria até hoje, que tinha elle faltado á sua verdadeira missão de proteger e auxiliar o commercio; teria merecido as censuras que espirtios systematicos e menos relectidos fazem a todos os bancps de circulação, e de se retrahirem quando o commercio mais precisa de seus serviços e dos grandes recursos de que podem dispor (grifo nosso). A esse procedimento se attribuirião os incalculabeis desastres inevitavelmente se deverião dar, e nem ao menos teria o Banco com bom senso e intelligencia zelado e resguardado os seus proprios interesses; pois não obstante o estado regular de sua carteira, poderia tornar-se victima das perdas que a crise necessariamente havia de causar a seus devedores.

Com effeito á primeira commoção causada pela notica da catastrophe, forão todos os estabelecimentos bancarios assaltados para a retiradas dos depositos. Sendo esses depositos á vista e achando-se empregados em titulos e prazos, como poderião os banqueiros pega-los de prompto. Se não lhes fosse em auxilio o Banco do Brasil.

Com o auxilio do Banco muitos d'esses estabelecimentos se salvárão, sustentando sua posição e fazendo face ao pagamento dos depositos; algumas casas não puderão resistir á catastrophe, e tiverão de suspender igualmente os seus pagamentos, declarando-se fallidas.

Faltárão de repente ao commercio varias casas bancarias com que tinha relações estabelecidas; as transacções da praça cessarão, porque pelo effeito do pânico a desconfiança manifestou-se, e os capitaes se retrahirão e occultárão.

Em tão graves e melindrosas circumstancias é facil de ver quaes serião as conseqüenciais, se o Banco do Brasil, em vez de francamente prestar auxilio e recursos ao commercio que d'elles precisava, tivesse o procedimento que hoje retrospectivamente se lhe aconselha (grifo nosso).

No estado de desanimo e de terror em que se achavão os espirios, e tendo completamente desapparecido os capitaes e importantes intermediários das transacções, o commercio não poderia resistir, e á inacção e indifferença do Banco do Brasil corresponderia a fallencia da maior parte do commercio d'esta praça mórmente do que mais intimamente está ligado com a lavoura.

Eis como o Banco do Brasil, tendo em vista unicamente os seus os seus proprios interesses, seria victima do erro fatal de ter desconhecido a importancia dos serviços que poderia prestar.

$\mathrm{O}$ que se deu então na nossa praça, é o que acontece e tem acontecido em todos os paizes em que se faz largo uso do credito, como o attesta a historia das mais notáveis crises commerciaes.

A retracção em que se collocão os bancos, e as medidas de segurança que tomão no momento do perigo aggravão a situação, quando pelo contrario, o alargamento da emissão seria o único remédio salutar e efficaz. As crises mais notáveis dominão-se e só podem ser superadas quando os bancos facilitão então os seus 
recursos, porque n'essas situações o elemento unido de vida é o meio circulante, que vem momentaneamente supprir o vasio feito pelo capital que desapparece.

O Banco do Brasil assom o comprehendeu,e, para poder efficazmente prestar auxílios ao commercio, teve de augmentar consideravelmente a sua emissão.

O governo imperial tambem assim o comprehendeu, e abundando nas vistas da direcotira, veiu promptamente em auxilio do Banco do Brasil, promulgando o decreto n.3306 de 13 de setembro de 1864 (grifo nosso), que facultou a emissão ao triplo do fundo disponivel, e logo, como consequencia necessária d'aqulle primeiro acto, promulgando igualmente o decreto n.3.307 de 14 do memso mez e anno que deu curso forçado ás notas de sua emissão; pois ao passo que o Banco do Brasil para socorrer a praça augmentava a emissão, diminua em igual proporção o fundo disponivel,-e tornava-se mais sensivel a cada instante desequilíbrio entre aquelles dous termos.

Este estado anormal, em que tão extraordinárias circumstancias tinhão collocado o banco, devia desapparecer pelo restabelecimento da confiança, que, fazendo voltar os depositos aos estabelecimentos bancarios, permitissem a retirada dos titulos descontados no Banco do Brasil , a diminuição da emissão em circulação, e finalmente restituíssem o banco ao regímen e condições normaes anteriores á crise.

Infelizmente, porém, augustos e digníssimos Srs. Representantes da nação, sobreveiu a guerra e com ella as urgentes necessidades do thesouro, o que tem absorvido a maior somma de capital fluctuante e disponivel, o qual teia de encaminhar-se ou para o Banco do Brasil, ou para os outros estabelecimentos bancarios; e em todo caso teria facilitado uma consideravel diminuição da emissão do banco.

A directoria do Banco do Brasil não tem dados para determinar com precisão a importancia total das quantias que tem o thesouro retirado da circulação para as necessidades da guerra;mas calcula que não poderá a sua somma ser inferior a 40.000:000\$000, para a qual tem concorrido não só os capitaes que se retrahirão da praça por effeitos da crise, como grande parte dos que se achavão depositados no Banco do Brasil e otros estabelecimentos de credito.

E se a esses 40.000:000\$000 se acrescentarem cerca de 8.000:000\$000 que o Banco tem por empréstimo fornecido directamente ao thesouro, ver-se-ha, augustos e digníssimos Srs. Representantes da nação, que sem as supevenientes emergências e necessidades da guerra, a emissão do Banco do Brasil, não obstante $o$ abalo e estemecimento, produzidos pela crise de 1864 , não excederia actualmente o limite maximo de 50.000:000\$000 que o projeto do Exm.Sr.ministro da fazendo fixa para circulação normal do mesmo Banco (grifo nosso).

Para neutralisar a concurrencia do thesouro, chamar a si maior somma de depositos e diminuir a sua emissão, poderia o Banco do 
Brasil recorrer ao meio que lhe tem sido aconselhado, de elevar a taxa de juro que paga pelos mesmos depositos. A directoria do Banco, porém, tem sempre repugnado essa medida, que poderia trazer embaraços ao thesouro, depreciar outros titulos que representão a divida do paiz, e afinal não produziria o effeito que se tem em vista; porquanto, faltando ao thesouro o recurso dos depositos particulares, teria de dirigir-se ao Banco para lh'os fornecer directamente por empréstimo.

A directoria do Banco do Brasil póde ter errado, mas tem preferido as mais injustas accusações a difficultar auxílios ao thesouro, na luta em que se acha empenhado o paiz; e, por isso sempre procurou não exceder a taxa de juro que paga o thesouro, recebendo a principio por menos, e depois por taxa igual, que até hoje tem conservado (grifo nosso).

Poderia igualmente a direcotira do Banco, com intuito de diminuir a sua emissão, adoptar a medida que ensinão os escriptores mais autorisados da sciencia econômica e aconselhão os homens mais versados na pratica das matérias bancarias; elevando a taxa dos descontos para contrahir a carteira. A elevação da taxa dos descontos, segundo esses mesmos mestres e escriptores, produz os melhores resultados em condições normaes de um banco de emissão, quando se dá depressão do cambio, e escoamento do fundo disponivel, sympthomas que revelão superabundância na circulação, que se corrige pela contracção da carteira.

Mas, nas condições especiaes em que se acha o Brasil, mórmente depois dos acontecimentos de setembro de 1864, e ainda mais depois que surgirão as extraordinárias necessidades do thesouro, fora uma illusão, augustos e dignissimos Srs. Representantes da nação, esperar tal resultado na elevação da taxa dos descontos.

N'um paiz essencialmente agrícola, cujo principal artigo de producção constitue a nossa primeira riqueza e o mais importante meio de permuta com os dos outros paizes, e em que entrentando não existe uma só instituição de credito real, a lavoura para abastecer-se dos capitaes indispensáveis ao seu agumento e desenvolvimento, recorria aos banqueiros e estabelecimentos bancarios, que lh'os fornecião, além dos seus proprios recursos, por meio dos depositos que recebião dos particulares; e a constante confiança do publico, e o equilibrio quase permanente entre as sahidas e as entradas d'esses depositos permittião que se fizessem a largos prazos os adiantamentos e recursos prestados á lavoura.

Era um erro fatal, era fixar-se sobre um volcão prester a devora-los a cada instante, e ao menos abalo, como os factos se encarregarão de demonstrar da maneira mais cruel e dolorosa! (grifo nosso)

Entretanto, erão os banqueiros e os estabelecimentos bancarios os intermediários entre os capitaes e a lavoura, e em taes circumstancias a elevação da taxa dos descontos do Banco do Brasil 
poderia trazer a contracção da carteira e a diminuição da emissão, porque os depositos facilitavão a retirada dos titulos descontados. Actualmente, porém, que por effeito da crise de setembro de 1864 e das necessidades do thesouro, os titulos que representão a divida da lavoura existem em grande parte no Banco do Brasil, e os depositos se encaminharão para o thesouro, a contracção da carteira e a diminuição da emissão não se podem esperar senão pelo pagamento real dos titulos descontados. E como esperar exigir-se o pagamento prompto e immediato dos titulos da lavoura, quando os capitaes que ella emprega não se reproduzem integralmente em espaço breve, e só por meio de uma quota annual de uma amortisação lenta se ópera a sua reproducção?

Essa amortização, a directoria do Banco a tem estabelecido e exigido em todos os vencimento das letras, apezar das vivas reclamações e que tem ella dado logar, e não obstante conhecer as dificuldades com que a luta a lavoura pela deficiência de colheitas regulares durante uma serie de annos.

A elevação da taxa dos descontos não traria, pois, a desejável diminuição da emissão, e só aggravaria a posição dos devedores do Banco; e é fundada nas considerações que ficam expostas que a directoria não tem igualmente lançado mão d'essa recurso, profícuo e efficaz em circumstancias diversas.

A directoria do Banco do Brasil, augustos e digníssimos Srs. Representantes da nação, julga ter demonstrado, não só, como muito bem diz um dos pontos do projecto do ilustrado Sr.ministro da fazenda, que o estado actual do Banco é o resultando da crise de 1864, como ainda que as circumstancias extraordinárias em que se tem achado $\mathrm{o}$ thesouro, contribuem consideravelmente para aggravarem-se as difficuldades da situação; e, finalmente, que as medidas de que efficazmente poderia a directoria lançar mão em circumstancias differentes, produzirião efffeitos contrários ao que se pretendessem alcançar.

Entretanto, augustos e digníssimos Srs. Representantes da nação, a direcotira do Banco do Brasil reconhece com o governo imperial a necessidade de se adoptarem medidas que restabeleção o mesmo Banco nas condições normaes de sua existencia, e melhorem o meio circulante do paiz; mas convicta de que as medidas propostas pelo Exm. Sr. ministro da fazenda produzirião calamidades maiores que os inconvenientes e males que se procurar evitar, o que certamente não está no pensamento do governo imperial, é que a directoria do Banco vem respeitosamente patentear a esta augusta cama os pontos em que, lhe parece, o projecto não corresponde ás intenções manifestadas pelo governo,e offende os direitos resultantes de um contrato existente entre o mesmo governo e o Banco do Brasil (grifo nosso).

O pensamento capital do projecto, manifestado nos considerandums que o precedem é restringir a emissão do Banco do Brasil até a somma de 50.000:000\$000 limite que em caso algum poderá o Banco exceder. 
Parece á directoria do Banco, augustos e digníssimos Srs. Representantes da nação, que basta a simples ennunciação do resultado final das medidas propostas, para condemnar todo o projecto como incompatível com a existencia do Banco do Brasil como banco de circulação; e melhor fora resolver-se a sua immediata liquidação, do que chegar ao mesmo fim com avultado prejuízo para o Banco, e grande sacrifício para o paiz.

E' principio corrente n'estas matérias, não contestado por escriptor algum autorisado e nunca desmetindo pela pratica, que não é possivel admitir a coexistência de duas espécies de circulação fiduciária, uma conversível e outra inconversível, pois que a inconversível expelle promptamente dos canaes da circulação a emissão conversível em metal, procurando afinal conveter-se em realidade e o representativo do valor no proprio valor .

Tal é entretanto a precaria e insustentável posição que o projecto destina ao Banco do Brasil.

O Banco do Brasil a custa dos maiores sacrifícios, e fazendo violenta pressão sobre seus devedores, conseguirá restingir a sua emissão a 50.000:000\$000 e abrirá o troco metallico de suas notas.

N'estas circumstancias a emissão do Banco terá como concorrente na circulação 40.000:000\$000 de papel do governo inconversível; e então é claro que tendo o Banco de sustentar uma circulação de 90.000:000\$000 á custa do seu fundo disponivel e do troco metallico de suas próprias notas, vêr-se-há forçado a suspender as suas operações e a entrar desde logo em liquidação. Não é este por certo, augustos e digníssimos Srs. representantes da nação , o pensamento enunciado pelo governo; mas os effeitos immediatos das medidas propostas conduzem inevitalmente a semelhante resultado.

A directoria do Banco deixa á illustração d' esta augusta camara o decidir se convém impor a um estabelecimento de credito como o Banco do Brasil, tantos e tão pesado onus e encargos, para chegar-se no fim de algum tempo a um resultado meramente negativo.

Os meios que indica o projecto para restringir a emissão do Banco consistem, principalmente, no pagamento em moeda-papel dos 11.000:000\$000 que o Banco tem recolhido á caixa da amortização por meio do resgate das notas do governo, e o pagamento em apólices da divida publica ao par, das quantias que estiver o governo devendo ao Banco por desconto de bilhetes do thesouro, não vencendo essas apolices juros em quanto as notas do Banco tiverem curso forçado, e devendo o Banco do Brasil retirar da circulação, no prazo que o governo designar, a importancia total das duas referidas sommas.

Quando á primeira somma de 11.000:000\$000, reconhece a directoria que, pelo contrato celebrado entre o governo e o Banco, subsistindo durante esse tempo o emprestimo sem juros, e gozando o Banco da faculdade de emissão equivalente. Quanto, porém, ao pagamento em apolices ao par da divida contrahida por desconto de bilhetes do thesouro, não póde a directoria occultar a dolora sopresa que lhe causou a manifesta 
injustiça de pretender o governo pagar uma divida contrahida por emprestimo, com titulos acima do preço por que livremente se comprão no mercado; causando assim ao Banco um prejuízo annual de varias centenas de contos de réis, pela cessação dos juros estipulados que essa divida vencia, e faltando-se por essa fórma á boa fé inherente a todas as convenções, mesmo entre os particulares, e sem a qual não haveria mais contrato possivel. Augustos e digníssimos Srs.representantes da nação, é no momento em que, para terminar com honra e dignidade a luta travada com os inimigos do império, precisa talvez o Brasil de procurar novos recursos nos mercados estrangeiros, e recorrer de novo ao credito de que até hoje tem elle gozado n'esses mercado pela escrupulosa fidelidade com que sempre tem procedido, que o governo acha mais azada a occasião para romper o seu contrato, pretendendo pagar menos do que recebeu, e impondo á outra parte contratante condições que não forão estipuladas.

Por honra e credito do Brasil, e por dignidade do proprio governo, augustos e digníssimos Srs.representantes da nação, uma tal medida não receberá a sancção do corpo legislativo; e o respeito devido á fé dos contratos será mantido por esta augusta camara, ileso, puro e sem a menor quebra.

Dir-se-há, augustos e digníssimos Srs.representantes da nação, como já se tem dito, que o governo pagando em apolices ao Banco do Brasil, nenhum prejuízo lhe causa, pois antecipa a época do pagamento a que pelo seu contrato era obrigado; e que podendo pagar em notas do thesouro a importancia dos bilhetes descontados, e esperar o vencimento do prazo para o pagamento da divida do resgate, ainda faz uma generosa concessão pagando em moeda, desde já, os 11.000:\$000 do resgate, e dando as apolices em pagamento dos bilhetes descontados.

(...) Pagando, porém, o governo anticipadamente essa importancia, deixa o Banco de perder os juros das quantias resgatadas mas perde por outra parte a faculdade da emissão correspondente; vindo portanto, a ser real e immediato pela cessão de juros, o prejuízo do pagamento em apolices ao par da somma dos bilhetes descontados. Ainda mais, augustos e digníssimos Srs.representantes da nação, a proposta do governo orbiga o Banco a retirar da circulação em notas de sua emissão, não só a quantia equivalente as 11.000:000\$000 resgatados, como tambem a impotancia dos bilhetes do thesouro descontados, que o governo pagará em apolices sem vencimento de juros.

Como poderá, porém, o Banco retirar da circulação a emissão equivalente á somma dos bilhetes do thesouro descontados, se o governo a pretende pagar em apolices que não vencerão juros?

Não podendo o Banco vender essas apolices, só exigindo immediato pagamento de seus devedores consiguirá a retirada da emissão correspondente.

A essa já avultada quantia, devem-se ainda acrescentar as mencionadas no arts. $4^{\circ}$ e $6^{\circ}$ do projecto; isto é, o Banco terá de retirar da circulação, além da importancia da divida representada 
por bilhetes do thesouro, mais a importancia dos lucros excedentes á $7 \%$, as quantias applicadas para o fundo de reserva, e mais semestralmente tambem a 3 a $6 \%$ das notas actualmente em circulação.

Será crível, augustos e digníssimos Srs. representantes da nação, que o commercio e a lavoura possão resistir a tão avultada e extraordinaria contracção mórmente nas circumstancias excepcionaes em que se acha o paiz, empenhado em uma guerra, externa que absorve e tem absorvido braços e capitaes, e depois de uns poucos annos de escassas e míngoadas colheitas do principal gênero de nossa producção?

Em circumstancias muito prosperas fora difficilimo; na situação actual do paiz, afoita-se a directoria do Banco a dizer que, exigir uma tal contraç̧ão, fora decretar a ruína geral.

Augustos e digníssimos Srs.representantes da nação, as considerações que respeitosamente, tem até aqui expendido a directoria do Banco bastão, no seu entender, para mostrar que a proposta apresentada pelo digno Sr.ministro da fazenda não só não consiguirá melhorar o estado do Banco do Brasil, collocando-o nas condições anteriores á crise de 1864 , como que o mesmo projecto, bem longe de realizar as benéficas intensões do governo imperial trará ao paiz incalculáveis males, aggravará as difficuldades da situação, e tornará impossivel por largo tempo o restabelecimento do mecanismo regular da circulação fiduciária, que circumstancias extraordinárias tem perturbado.

Poderia, pois, a directoria do Banco do Brasil, cônscia da illustração que distingue esta augusta camara, e, depositando a mais inteira confiança nos sentimentos que a animão pelo bem publico, pôr aqui termo ás considerações que the suggerirão as medidas propostas pelo illustrado Sr. ministro da fazenda, esperando tranquilla o resultado do estudo das deliberações d'esta augusta câmara (grifo nosso).

Mas, augustos e digníssimos Srs.representantes da nação, a directoria do Banco do Brasil não teria cumprido o seu dever, se depois de ter apresentado os inconvenientes, que, a seu ver, resultão das medidas econômicas indicadas no projecto do Exm.Sr.ministro da fazenda, não chamasse igualmente a vossa attenção para o aspecto moral do mesmo projecto, em que se propõem providencias que de akguma sorte affectão o caracter e a dignidade da administração do primeiro estabelecimento de credito do paiz, e o prestigio de que cumpre esteja sempre revestido o proprio representante do governo imperial n'aquelle estabelecimento.

Suppõe o projecto que o publico terá maior confiança na emissão do Banco do Brasil, uma vez que as notas do Banco forem substituídas por outras fornecidas pelo thesouro, com carimbo do thesouro e assignadas por empregados do thesouro.

A directoria do Banco do Brasil está intimamente persuadida de que a porposta não considerou maduramente, nem mediu o alcance de semelhante disposição; e se não fora a influencia que uma tal 
medida póde ter sobre o credito do estabelecimento, e se fora possivel considera-la unicamente em relação ao caracter pessoal dos membros de que se compõe a administração, por sem duvida a directoria do Banco nem um só instante se occuparia d'este ponto.

Quando, porém augustos e digníssimos Srs. representantes da nação, é o proprio governo do paiz que vem dizer ao corpo legislativo que a emissão do Banco do Brasil não inspira confiança ao publico, não por estar essa emissão fóra do limite normal, não por ser superabundante segundo os principios economicos que regem a circulação fiduciária, mas pelo facto de ter sahido dos cofres do Banco e de ter as assignaturas dos seus directores, abre-se campo largo ás conjucturas e corollarios por mais extravagantes que sejão, e para os quaes não ha defesa possivel.

Comprehemder-se-hia uma medida que fixando um limite para a emissão do Banco, determinasse que esse limite só podesse ser excedido para ocorrer ás necessidades do thesouro, e que as notas que representassem o excesso tivessem um signal ou carimbo do proprio Banco que facilmente as distinguisse.

Substituir, porém a emissão sahida dos cofres do Banco por notas fornecidas pelo thesouro, julga a directoria que equivale a suscitar uma suspeita, que os mais systematicos terroristas, os mais implacáveis inimigos do Banco, e os que menos possão confiar na estabilidade d'este estabelecimento, nunca um só instante conceberão.

A directoria do Banco do Brasil ufana-se de poder assegurar a esta augusta camara, sem receio de ser contestada, que graças ao zelo, intelligencia e dedicação da primeira directoria, ás regras por ella fixadas, e que invariavelmente têm sido observadas até hoje, e administração e serviço do Banco do Brasil em tudo quanto diz respeito á emissão de notas, são de uma regularidade e perfeição sem rivaes no paiz e constituem um verdadeiro modelo.

A substituição, pois, da emissão do Banco por outra fornecida pelo thesouro, nenhum accrescimo de garantia poderia dar ao publico; ao passo que só a proposta da medida póde diminuir o credito do estabelecimento.

A directoria do Banco do Brasil, augustos e digníssimos Srs. representantes da nação, não quer, nem deseja, eximir-se da responsabilidade dos seus actos e acoberta-los com uma inspecção official; e desde que o projecto estabelece a internveção do governo nas funç̧ões da directoria que mais tem o caracter e o cunho de propriamente commerciaes, e retira aos directores do Banco a faculdade de livremente exercerem o mandato que receberão dos accionistas, um tal cargo, honroso até aqui, amesquinha-se e tornar-se inaceitável, e melhor fora para maior e mais segura garantia dos interesses e capitaes dos accionistas do Banco, acabar de uma vez com esse simulacro que fica sendo de administração e gerencia, tornando-se completa a tutela, e assumindo o governo toda a responsabilidade da administração do Banco e dos interesses com elle estão ligados (grifo nosso). 
A directoria não falla na commissão fiscal até agora nomeada pelos accionistas, e que tinha por muito especial attribuição o exame das operações de desconto, por entender que desapparece essa entidade em face do systema de administração inaugurada pela proposta do governo.

Augustos e digníssimos Srs. representantes da nação, a directoria do Banco do Brasil julga ter demonstrado que não forão abusos que ella praticasse que levárão o banco á situação anormal em que se acha, e que as medidas propostas pelo Exm.Sr.ministro da fazenda não remediarão os males que a directoria do banco tambem reconhece de indispensavel necessidade reparar, senão postergando os mais sagrados direitos e impondo ao paiz sacrifícios que por largo tempo tornarião impossível o mecanismo regular da producção da riqueza e o restabelecimento em suas condições normaes de uma verdadeira circulação fiduciária, que é o pensamento dominante e o principio cardeal da lei n.683 de 5 de julho de 1853 .

Se as circumstancias extraordinárias em que se tem achado o paiz são inconstestavelmente a causa principal do estado da emissão do Banco, e das perturbações econômicas que d'ahi provém, parece a boa razão que se procure com toda a prudencia e criterio corrigir esses inconvenientes por medidas adequadas, que não tragão calamidades maiores que os perigos que se procura evitar, até que melhorando essas mesmas circumstancias e o aspecto geral do paiz, se possa desassombradamente e com mais afoiteza marchar para o desejado fim.

A directoria do Banco do Brasil, augustos e digníssimos Srs. representantes da nação, não se julga autorisada nem competente para indicar a esta augusta camara as medidas que, no seu entender, poderião contribuir para melhorar o estado do Banco sem causar abalos que aggravem as difficuldades e a situação critica em que se acha o paiz ; mas, tratando-se de alterações tão profundas na organisação do Banco do Brasil e das condições essenciaes de sua existencia, que tem por base um contrato celebrado entre o governo e o mesmo Banco, confiante espera que esta augusta camara se dignará de attender aos direitos resultantes do referido contrato, e a todas as conside rações eu respeitosamente submette ao seu illustrado criterio para resolver as medidas que reclama o paiz, de modo que se conciliem as vistas do governo com o interesse geral e com os direitos e interesses dos acionistas do banco.

A directoria do Banco do Brasil, augustos e dignissimos Srs. representantes da nação tem sobejas provas de illustração e patriotismo dos legisladores do Brasil para que possa duvidar um só instante de que, qualquer que seja a deliberação que houve de tomar ácerca do projeto do Exm.Sr.ministro da fazenda, fará esta augusta camara prevalecer e triumphar, como já o disse uma voz das mais autorisadas e respeitadas do paiz-os principios de justiça e o respeito devido á fé dos contratos (grifo nosso). (p. 9-16). 
Em 1868, a diretoria do Banco do Brasil fez uma série de questionamentos acerca do relatório apresentado pelo Ministério da Fazenda, que tecia duras críticas à postura da referida instituição financeira $(\mathrm{BB}, 1868)$ :

S. Ex. porém olvidou-se da existencia das outras caixas filiaes do Banco do Brasil, que tem igualmente emissão, resultando dahi e enorme differença para menos de 16.154:670\$000 em que importa a circulação das seguintes caixas omittidas no calculo do Ministro:

(...) Demonstra-se assim que na data a que se refere S.Ex. no seu relatorio, a circulação total do Banco do Brasil era de 57.069.505\$000 e não de 40:914:865\$000, o que aliás consta dos balanços e documentos remettidos ao thesouro.

(...)o decreto n.3814 de 16 de Março de 1867, imposerão ao Banco essa obrigação, por não ser necessária, e por attenderem ás difficuldade praticas que trairão consigo, deixando ao criterio e experiencia da direcção do estabelecimento o operar a dita amortisalão pelo modo mais conveniente. (...) S.Ex. parece ter confundido a proporção de que se trata, com a prescripta no decreto de 16 de Março do anno passado, sobre o resgate das notas pela venda do fundo metálico do Banco.

(...) a memória da futilidade e injustiça dessas publicações anonymas.

As censuras são as seguintes:

1. Proceder a directoria do Banco com incuria, erro e malversação, entendendo a lei de 12" de Setembro de 1866 como um meio de reembolçar-se dos capitaes mal empregados pelo proprio(...).

(...)Como é que o Banco poderia auxiliar a lavoura e o commercio sem primeiramente reembolsar-se dos capitaes ?(...).

(....) As industrias do paiz. Quanto mais rápidas e fecundas são liquidações, mais numerosas são as evoluções de seu capital e maior a somma(...).

(...) malversação um facto normal, e que representa a parte fundamental do mechanismo faz insituições de credito?

Por outro lado, não é também exacto, que a directoria(...) commercio na medida de seus recursos e dentro dos limites traçados por seus Estatutos.

(...) 12 de Setembro de 1866 ha sido religiosamente cumprida na parte hypothecaria, e producto das respectivas amortizações não tem tido outra applicação que não seja a de novos empréstimos sobre a mesma garantia.

(...)Pelas circumstâncias calamitosas da quadra actual, o numero dos novos titulos d'esta espécie deminuio; e a Directoria para não deixar dormir improductivamente $\mathrm{o}$ fundo superabundante da caixa commercial, tem empregado no desconto dos bilhetes do Thesouro, com aprasimento e elogio do ex-Ministro da Fazenda. (...) 2. ${ }^{\circ}$ Distribuir-se em Julho de 1867 um dividendo de 12\%, quando o capital do Banco, deve considerar-se irrealisavel, estando consumido em mais de $50 \%$. 
Respondo, que os Estatutos prescreverão regras precisas e terminantes sobre distribuição dos dividendos dos semestres, excluindo o arbítrio da directoria á tal respeito no art. $8^{\circ}$ que é o seguinte:---“Dos lucros liquidos do Banco provenientes das operações effectivamente concluídas no respectivo semestre, se deduzirão $18 \%$ para um novo fundo de reserva--- a somma precisa para um dividendo de 9 a 10\%---4\% da importancia do dividendo para retribuição da Directoria. Depois de feitas estas deducções, o que exceder será destinado ao coadjuvar a amortização das notas.

Se acontecer que o excedente destinado para esta amortização seja superior á importancia annual da mesma amortização, neste caso sómente as sobras que houver, serão applicadas no augmento proporcional do dividendo.

(...) a totalidade da somma, que a não ser a dispensa, houvera consagrado á amortisação. Mas a directoria, para evitar devidendos excessivos, não obstante o favor do referido Decreto, tomou a responsabilidade de retirar a renda liquida do semestre a que perencia, o ágio do ouro vendido ao governo no valor de $2,395,454 \$ 415(\ldots)$.

(...)imperfeições reaes ou suppostas dessas obra organisada pelos commissarios da Assembléa Geral,e que só ao Governo competia emendar, como effectivamente $\mathrm{o}$ fez com as modificações constantes do supramencionado Decreto?

(...) Quando mesmo taes impossibilidades não existissem, seria um espetaculo indigno, que o primeiro estabelecimento de credito, e tão altamente favorecido, especulasse sobre os eclipses da fortuna do Estado, tornando dependente o exito de seus calculos aleatórios dos revezes ou importancia de nossas armas e do progresso da ruína de nossas finanças.

(...) $-6 .^{\circ}$ Não se indagar com anecessaria antecedência do estado de solvabilidade de certos devedores, , com quem mais tarde se fizerão composição com prejuízo de $80 \%$

E falso que a directoria concluísse taes concordatas; e quando e fizesse poderia ter tido para isso excellentes razões. $\mathrm{O}$ facto alludido nesta censura é o de um devedor cuja propsta de concordata de $50 \%$ foi rejeitada pela directoria, preferindo a immediata abertura de fallencia. Sobre a segunda proposta mais razoável resolven o banco tomar a sai para sem reembolso a totalidade das letras de que era portador, e que representavão os tres quartos da divida, recebendo $20 \%$ em garantia, unicamente do resto da divida, que se achava irremediávelmente coberta com uma firma insolvável desde 1864. As perdas das concordatas não avalião-se pelos abatimentos feitos em uma ou outra parcella da divida; mas sim sobre a reducção no seu total; e na hypothese vertende o abatimento concedido foi inferior a $40 \%$.

---7. ${ }^{\circ}$ Fazerem-se em geral devidendos, que não são na realidade resultantes dos lucros realisados mas verdadeiras deducções do capital, senão dos depoistios.

A perfeição da escripturação do Banco, a publicidade dos documentos demonstrativos de suas operações, a notória 
probidade de seus directores e funccionarios, dispensão-me de responder esta miserável e brutal calumnia. (grifo nosso). (p. 9).

Com a reorganização do Banco nos fins dos anos 60 e início de 1870, tomam novamente corpo a interação e a troca de favores entre o Governo e o Banco, principalmente no tocante ao resgate das notas desta última (BB, 1877):

Por contracto firmado pelo Exm.Sr.Conselheiro Ministro da Fazenda em 23 de Janeiro, negociou este Banco a compra de 30.000 apolices ao preço de $970 \$ 000$ por 1:000\$000 sendo as condições de pagamentos e demais obrigações as que constão do respectivo contracto, cuja integra encontrareis em annexo.

Assim procedendo teve a Administração em vista não desfalcar a Caixa, de modo que as operações commerciaes se resentissem do menos abalo. (p. 6).

Com a saída da crise dos anos 60 a passos largos, a instituição financeira faz menção à excelente participação do poder político $(\mathrm{BB}, 1875)$ :

Este resultado, porém, não se teria obtido facilmente sem aquelle concurso do Governo Imperial, a quem o Banco do Brazil e o Commercio desta praça devem franco reconhecimento. (p. 5).

E novamente, já no final dos anos 70 e em praticamente todos os 80 , são elucidados alguns embates entre o banco e o governo, a força coercitiva do mesmo é apontada (BB, 1879):

Não havendo S.Ex. approvado a intelligencia dada, nem attendido á representação que lhe foi dirigida pela directoria, expondo longamente os motivos de sua deliberação, resolveu-se cumprir a decisão do Exm. Sr. ministro da fazenda por falta de outro qualquer recurso legal. (p. 9).

Percebemos nesses últimos 15 anos de Império cada vez menos elogios ao poder político vigente e são evidenciados indícios daquilo que estava porvir. Exemplificamos com o ano de 1887 (BB, 1887): 
Por Decreto Imperial de 4, publicado no Diario Official de 11 de Agosto, forão approvados com modificações os novos Estatutos do Banco, votados em Assembléia Geral de 27 de Agosto de 1885, os ques se achão em execução desde o dia 16 do dito mez.

Com referencia á emenda ao art. 59 da reforma, que foi mandada substituir pelo art. 50 dos Estatutos com modificações, pareceo á Administração conveniente reclamar do Governo Imperial que fossse restabelecido o art. 59 da reforma na sua integra, alem de que muitos accionistas mostrarão igual opinião, e aguardo solução, que vos será em tempo communicada. (p. s/n $\mathrm{n}^{\mathrm{o}}$ ).

(...)

Tratando do movimento da Caixa devo communicar-vos que, de conformidade com as disposições da lei n. 3263 de 18 de Julho de 1885, a administração do Banco propoz ao Governo levantar emprestimos mediante caução de bilhetes do Thesouro.

Só levada por causas muito justificadas teve a administração de lançar mão d'este recurso extremo, o qual foi favoravelmente resolvido pelo illustrado Sr. Ministro da Fazendo acceitando as propostas do Banco. (p. 14).

Durante a República da Espada (1889-1894), a interferência do Governo se dá de maneira mais direta, inclusive em relação à reorganização decorrente da fusão, resultante no Banco da República do Brazil, bem como na questão monetária do fim do século XIX e início do século XX (BB, 1891, 1895, 1896, 1897, 1898):

O marechal Manoel Deodoro da Fonseca, chefe do Governo Provisorio, constituido pelo Exercito e Armada em nome da Nação: Considerando a necessidade immediata e inevitavel de ampliar largamente o meio circulante, attenta a extrema tensão do mercado monetario ;

Art.1. ${ }^{\circ} E^{\prime}$ autorizado o Banco do Brazil, assim como o Banco Nacional do Brazil, a emitir bilhetes ao portador até ao duplo da quantia de 25.000:000\$ cada um.

(...)

(...) usando do direito que lhes confere o $\$ 2^{\circ}$. do art. $4^{\circ}$. do decreto n. 1.154 de 7 de Dezembro de 1890, e autorisados por despacho de 23 do corrente mez, proferido por S. Ex. o Sr. Ministro da Fazenda, deliberarão e accordarão entre si a cessão e transferencia ao Banco da Republica dos Estados Unidos do Brazil pelo Banco do Brazil dos direotos e privilegios (...) seguintes clausulas: $1^{\text {a }}$. fica pertencendo ao Banco da Republica dos Estados Unidos do Brazil a propriedade da somma de vinta e cinco mil contos em ouro, depositados pelo Banco do Brazil (...) 2 ${ }^{\mathrm{a}}$. o Banco da Republica dos Estados Unidos do Brazil obriga-se a pagar em ouro, á vontade do portador e á vista, nos termos do $\S 2^{\circ}$. do art. $1^{\circ}$. do decreto n. 253 de 8 de Março de 1890" (1891, p. s/no 
(...) pelo qual ficam rescindidos os contractos celebrados entre o Governo e o dito Banco em 3 de Agosto de 1888, em 9 de Outubro de 1888 , e em $1^{\circ}$ de Agosto de 1889 , para prestação de auxilios á lavoura, sendo substituidos pelo constante das seguintes clausulas: 1. O Banco do Brazil indemnisará a Estado da quantia de 8.000:000\$000 que do mesmo recebeu, no fim de dezesete annos, prazo maximo estipulado na clausula $12^{\mathrm{a}}$ do accôrdo celebrado em $1^{\text {o }}$ de Agosto de 1889. (1891, p. 46)

(...)

(...) cometteu ao nosso instituto de credito, não podia deixar de ser lenta e demorada. Ás causas conhecidas, originadas da crise economica que ainda perdura ; ás que a mais elementar previsão deixava antever, vieram juntar-se outras, inesperadas e temerosas, que por vezes fizeram descrer do bom succedimento da obra apenas encetada.

Para superar as difficuldades, que essas causas geraram, e vencer os consequentes embaraços provindos do mal-estar economico do nossa praça, empenhou a digna Administração os mais laboriosos esforços, apoiada no concurso que o Governo jámais lhe negou (...) $\left(1895, \mathrm{p} . \mathrm{s} / \mathrm{n}^{\mathrm{o}}\right)$

(...)

Para a concecussão de taes resultados muito hão concorrido - justiça é confessal-o - reflectindo zelo e os perseverantes esforços da digna Directoria, á qual nunca faltou o apoio do Governo, nem a confiança publica, aliás sempre manifesta em favor do Banco da Republica (1895, p. s/n) (...)

E'-me summamente agradavel confirmar o testemunho, já prestado pelo meo illustre antecessor, da perfeita cordialidade que continúa a presidir ás relações reciprocas entre os Srs. Directores de eleição e os de nomeação, enviando uns e outros, egualmente, esforços harmonicos em bem da prosperidade do Banco, sem attrictos pessoaes, que só poderiam prejudicar o regular funccionamento das diversas carteiras especiaes por que se acham distribuidos os multiplos e variadissimos negocios que óra se enfeixam neste importante Instituto. Aliás, não ee isso para admirar, attenta a circumstancia de ter o Thesouro Federal empenhados no Banco da Republica do Brazil interesses tão avultados e valiosos como os dos proprios Srs. Accionistas, de que são representantes directos os directores eleitos, - interesses que não são, nem podem ser, divergentes, $e$ menos antagonicos, Accresce que é grande o empenho dos Poderes Publicos Federaes pelo fortalecimento do principal instituto de credito da Republica, visando habilital-o a prestar, no mais curto prazo, ao commercio e á industria nacionaes, todos os serviços correspondentes aos patrioticos intuitor da poderosa organização com que for dotado pelo Congresso Nacional (grifo nosso). (1896, p. 11).

(...) 
Não é possivel, por emquanto, fixar a cifra exacta da reducção que o accôrdo trará, desde já, á divida do Banco para com o Thesouro Federal, por depender essa cifra ainda de resolução do Governo quanto á diversas propriedades offerecidas em encontro de contas. Pode-se porém calcular que essa reducção não será inferior a Rs. 115.000:000\$000, ficando reduzida a divida a menos de 80.000:000\$000, para cujo pagamento foi concedido o prazo de 20 annos sem juros, mediante amortização de $2 \%$ ao anno no $1^{\circ}$ quinquenio. - A grande somma de valores que possue o Banco, immobilisados em sua carteira, e de que só lentamente poderá dispôr, á menos que não se sujeite a sensivel prejuizo, aconselharam a concessão de largo prazo para extincção do restante de sua divida. O computo da media de lucros que tem auferido o Banco durante os quatro annos de sua existencia, demonstra claramente que poderá elle cumprir suas obrigações, e encarreirar uma época de prosperidade, desafogado como fica de uma importante parte de sua divida.

Por sua parte o Governo fazendo razoaveis e equitativas concessões, que redundam em fortalecimento da situação do Banco, que é a principal instituição de credito da Republica, procedeu como credor avisado, que tudo tem a lucrar com a melhoria de situação de seu devedor, além de fazer acto de previdente gestão governativa, cujo maximo empenho deve ser eliminar os effeitos de uma crise profunda que tanto tem affectado a vida dos Bancos e Emprezas industriaes do Brasil, nos ultimos annos. O renascimento da confiança é condição essencial para o desapparecimento do mal-estar, que affecta todas as classes da sociedade (grifo nosso). (1897, p. 14). (...)

A reforma dos Estatutos, operada em virtude da Lei n.427 de 9 de Dezembro de 1896 e approvada pelo Decreto n. 2509 de 8 de Maio ultimo e o accordo celebrado com o governo em data de 18 do mesmo mez de Maio, para pagamento da divida do Banco ao Thesouro, são os factos culminantes do anno findo e de inflluencia duradoura e decisiva ppara a prosperidade do nosso Instituto.

Pela entrega de bens e titulos, feita pelo Banco ao Thesouro, ficou a divida redusida a 94.670:149\$783 de 194.649:000\$510 que era em 31 de Dezembro de 1896, verificando-se uma diminuição de 99.548:850\$727. (1898, p. s/n $\left./{ }^{\circ}\right)$

Conclusão da seção:

Como destacado por Gramsci (1999), para a ação hegemônica, o discurso e a ação não podem parecer apenas como realização dos grupos diretamente beneficiados.

Deve-se refletir como expansão dos anseios de todos. 
Para isso, a sociedade civil tem papel fundamental, já que esta é a encarregada da propagação ideológica.

Assim buscamos estudar nessa seção a interface entre sociedade civil e sociedade política no caso brasileiro em primeiro lugar em relação ao interesse fim da instituição: público ou privado.

Visualizamos que o discurso empregado era de interesse público, este muitas vezes confundido com aqueles do governo e acionistas. Porém as ações beneficiaram estritamente os dois últimos.

Nesse certame, visualizamos as tentativas de se criar a ideia de que seus atos nada mais eram que a expansão universal do anseio geral.

Também identificamos os elementos de coerção e consenso da sociedade política em relação as atividades em que estava circunscrito o Banco do Brasil.

As benesses trocadas entre governo e banco, o primeiro dando política e dando dinheiro e recebendo mais dinheiro ainda eram métodos de coerção tanto para o banco em si, quanto para outras instituições, principalmente em relação à sensível questão monetária do século XVIII e início dos XIX.

O próprio financiamento de guerra é um exemplo desse poder coercitivo do Estado, como no caso do alto desembolso com a caríssima Guerra do Paraguai nos anos 60. 
$\underline{3.2 b}$ - A visão sobre as revoltas no país

Na última década do século XIX, mesmo com a mudança de poder político, as condições de vida da população ainda eram de miséria e desigualdade.

Foram tentadas algumas experiências por parte dos explorados, na construção de uma sociedade mais justa, longe das pressões e castigos dos latifundiários, sobressaindo-se o caso de Canudos (Bahia - 1896 a 1897) e sua esmagação por parte do Governo Militar.

Mesmo dentro do círculo militar (mais notadamente na Marinha), a insatisfação era grande, muito em decorrência da postura centralizadora do Marechal Deodoro da Fonseca, culminando na Revolta da Armada (Rio de Janeiro - 1891, 1892 e 1893).

Nosso objetivo é demostrar a visão do poder dominante acerca desses movimentos sociais e característica comum da ação do governo (e o apoio a essa visão por parte dos primeiros) de que eram perturbações e como tal deveriam ser banidas (e assim o foram, como contado pela hstória).

Iniciemos com as Revoltas da Armadas deflagradas nos primeiros anos de 1890 (BB, 1894):

Nascido da fusão dos dous Bancos - o do Brazil e o do Republica dos Estados Unidos do Brazil - o novo instituto teve de arcar com a temerosa crise economica cujos desoladores effeitos excedem as mais arrojadas apreciações. Para aggravar esta situação, já se si deploravel, vieram ainda os lamentaveis movimentos revolucionarios, que trouxeram as maiores perturbações á actividade commercial industrial do paiz e especialmente da nossa praça.

O Banco da Republica do Brazil pôde superar os grandes e graves embaraçosos que desse estado anormalissimo lhe advieram (grifo nosso), e o Relatorio, que é antecedido do presente parecer, dá-vos noticia, tão circumstanciada quanto possivel, não só da situação das suas differentes Carteiras como tambem dos serviços que lhe foi dado prestar ás forças vivas e productoras do paiz, das quaes é natural auxiliar. (p. 2)

(...) Se era já angustiosa a situação da nossa praça, semelhante crise mais se aggravou diante de acontecimentos politicos de tanta magnitude e que deveriam ter a sua natural e malefica repercussnão sobre todos os ramos da nossa actividade, entorpecendo 0 commercio, prejudicando as industrias, 


\section{deprimindo o cambio, cimentado o nosso descredito no estrangeiro, atemorisando o capital, e em summa causando perturbações de toda a ordem á nossa vida politica, economica e financeira (grifo nosso). (p. 6 e 7)}

A nossa primeira república oriunda de um golpe arquitetado por militares e alguns membros da oligarquia cafeeira e outros insatisfeitos aos desenlances com o regime monárquico foi uma ditadura em seus aspectos.

Sendo apenas um período de passagem entre dois períodos hegemônicos (Gramsci, 1999), as revoltas sociais, tanto de setores mais baixos da sociedade com Canudos ou mais ligados à dinâmica do poder como os membros da Marinha Brasileira no caso fluminense, eram de tal forma colocadas como causas da situação de calamidade economica e social no país nesses anos, com capacidade de entorpecer o comércio e cimentar nosso descrédito como visto acima (BB, 1894, 1895, 1896, 1897):

E' impossivel imaginar o que foi esse longo periodo de verdadeira tribulação por que passou o nosso paiz, principalmente durante os muitos mezes em que a Bahia do Rio de Janeiro foi o theatro de uma guerra fraticida, em que muito soffreu esta capital e principalmente a cidade de Nictheroy, até então capital do Estado visinho.

As reciprocas e intimas relações entre o Governo e o Banco, enfeixadas nas mutuas dependencias destas duas entidades, constituindo o systema do Decreto de 17 de Dezembro, refundido na Lei de 23 de Setembro, estabelecem um jogo isochrono de oscillações em que, ora é o credito publico que vem em auxilio do Banco para poder este prover ás justas necessidades de sua clientella em épocas de retrahimento e de comprovadas necessidades, mal equilibradas por economias deficientes, ora ao contrario é o Banco que, em periodos de maior folga dos que a elle recorrem, póde dispôr de suffcientes reservas afim de ir amostisando necessarios mediante adiantamentos por antecipação da receita

Neste fluxo e refluxo de circulação do capital, neste complexo conjugado em que duas entidades poderosas actuam como forças complementares, reside exactamente a harmonia do systema financeiro de que o Banco da Republica é uma peça importantissima.

D'ahi os corollarios naturaes do funccionamento regular de um apparelho calculado para agir com uma super-actividade que chegou a ser devéras extraordinaria!

Diversos factores, da maior importancia, influiram de feito para que o phenomeno economico e financeiro se passasse nas maiores proporções a que jámais attingio uma crise em nossa patria. 
Immensas foram, é certo, as necessidades determinadas pela cessação de actividades de toda a ordem e pelas apprehensões e incertezas motivadas pelos crueis momentos que atravessamos; mas em compensação tambem grande foi sempre a confiança de que constantemente se vio cercado este estabelecimento para onde refluiam, ainda mesmo no periodo o mais critico, as economias possiveis do rico, do remediado e até mesmo do pobre.

A justiça manda se consigne que, n'um supremo lampejo de verdadeira videncia, teve o Governo do paiz uma sabia intuição de sua acção impulsora, mantendo corajosamente, e sempre dentro dos recursos legaes, o credito inteiro deste estabelecimento, cuja vida não tem para elle mysterios, e em que via com sufficiente clareza os elementos latentes de sua prosperidade, aguardando apenas para sua fecunda proliferação a copartição indispensavel dos tres poderosos elementos: $1^{\mathrm{o}}$ a normalidade da nossas vida social, imprescindivel para a previsão segura da valorisação das riquezas; $2^{\circ}$ a prudencia, aconselhada pela experiencia resultante das facilidades, illusões, erros e desatinos de um periodo de allucinações epidemicas; $3^{\circ} \mathrm{o}$ tempo, esse multiplicador maravilhoso que, com pequenas economias, amontôa thesouros sorprehendentes.

$\mathrm{Na}$ troca de reciprocas relações de intimidade e de concursos é dever imperioso desta Directoria agradecer ao Governo o auxilio efficassissimo que sempre delle recebeu. (1894, p. 7-8).

(...)

No Governo do Sr. marechal Floriano Peixoto, que tão valioso apoio prestou a este Banco, a conversão do lastro que serve de garantia á emissão, como determina o art. $6^{\circ}$ da lei de 23 de Setembro de 1893, não foi levada a effeito apezar dos nossos esforços e ddos outros interessados ; o Governo Federal preoccupado com a guerra civil e com as consequencias que d'ella sobreviveram, não pôde resolver as questões que áquelle respeito se suscitaram.

O novo Governo, de quem o Banco continúa a merecer o mesmo apoio, prepara-se para resolver esta questão e creio que fal-o-ha brevemente. (grifo nosso). (1895, p. 13).

(...)

Por esse documento vereis que o nosso Instituto de credito, luctando embora com sérias difficuldades, ainda não de todo extinctas, originadas da grave crise economica e das não menos graves convulsões politicas (grifo nosso), alcançou no anno ultimo resultados que, sobre serem animadores, abrem margem á bem fundada esperança de proxima e definitiva consolidação do Banco. (1896, p. s/n)

(...) Durante o anno findo de 1895, fizeram-se ainda sentir infelizmente com bastante intensidade - os funestos e desastrosos effeitos da crise financeira que tem pesado sobre o paiz desde 1892, e cuja liquidação vae-se arrastando penosa e lentamente, difficultada por causas varias e complexas que, todavia, já parecem tender a proximo desapparecimento. Assim é que, no correr de 1895, apresentam-se mais serenos e desanuviados os 
horizontes politicos, permitindo jogo mais nórmal do machinismo institucional dos Poderes Publicos Federaes, dissipadas as penosas apprehensões de perturbações revolucionarias, que tanto mal causam ao credito publico e particular, impedindo a marcha regular dos negocios. Não ha contestar que taes perturbações são, geralmente, inherentes ao inicio de instituições politicas que forcejam por firmar e consolidar o regimem que lhes é proprio, e encontram - como é natural - resistencia em habitos e interesses radicados que precisa contrariar; e, por tanto, tendem fatalmente a desapparecer a proporção que se vae desenvolvendo a experiencia governativa dos homens novos e a adaptação dos novos moldes admnistrativos. (grifo nosso)" (1896, p. 11 e 12). (...)

De quanto ahi fica summariado, claramente se evidencia que o nosso grande estabelecimento de credito tem continuado a merecer o mesmo favor publico, que nunca o abandonou, e a mesma confiança dos Poderes da Republica" (1897, p. 6).

A tentativa ideológica era de tratar esses fenômenos como perturbações e como tal, deveriam ser banidas para a volta da ordem e como mencionam do fim de todos os males econômicos e sociais que nosso país vivia àquela época.

A história nos conta quais e como foram os desfechos das respectivas revoltas: a experiência governativa dos homens novos se resumia a aniquilar os adversários, que tendem naturalmente a desaparecer...

\section{Conclusão da seção:}

Conforme colocado por Gramsci (1999), a ditadura como período transitório entre duas fases hegemônicas, se resume ao poder político de um grupo não hegemônico e o uso coercitivo para conformar as massas.

No caso ditadorial percebemos o apoderamento da sociedade civil por parte do poder político então vigente a fim de disseminar os inconvenientes de tais movimentos tidos como revolucionários.

Verificamos, pois, que o poder político ditatorial brasileiro da República da Espada, apodera-se de entes da sociedade civil, no caso o Banco do Brasil, a fim de modelar a 
opinião pública de que tais movimentos eram aberrações, causadores, inclusive dos males estruturais econômicos e sociais, anteriores aos próprios movimentos revolucionários, e que, deveriam ser de tal forma aniquilados para a volta da ordem e do progresso.

Todavia, assim como apontado por Gramsci (1999), percebemos o sinal do esboroamento de seu poder quando do uso excessivo e constante da força: fato esse a tônica na tratativa dos movimentos sociais em questão.

Como ensinado pelo sardo, não se forma hegemonia apenas com coerção: também se faz necessário o consentimento. (Gramsci, 1999). 
3.2c - Transição do regime político: do Império para a República Militar e da República Militar para a República Oligárquica

O objetivo dessa seção é identificar os traços ideológicos do banco, representante da sociedade civil porém com alta influência governamental, no tocante às mudanças ocorridas no poder político brasileiro, com a queda do Império para a República Militar (1889) e da República Militar para a República Civil Oligárquica (1894).

Queremos verificar a interface entre os dois tipos de sociedade, mesmo com a mudança explícita em uma delas.

Também nesse certame, identificamos que em épocas anteriores ao momento fatal da transição, já ocorre um distanciamente entre banco e poder político, tanto em questão de ação quanto de discurso. Exemplo disso é o elucidado em 1887 (BB, 1887):

O augmento dos negocios realizados pelo Banco do Brazil durante o anno findo, é phenomeno digno de nota e faz transluzir a esperança de que recrudesça a actividade commercial, triumphante dos perigos que a assedião e ameação. $O$ melhoramento realmente verificado no systema financeiro do Estado, estabelecendo uma solução de continuidade, senão um verdadeiro e louvavel retrocesso no vicioso regimen de arrancar á praça avultados capitaes, destinados a augmentar os seus recursos e os seus meios de acção; esse pernicioso regimen que depaupera e enfraquce o commercio, privando-o de sus naturaes recursos durante longos periodos de tempo em que o Estado os absorve, é dupla calamidade, não só pela privação que chega a constituir uma lenta agonia, mas ainda, e talvez mais, pelos graves perigos de periodicas devoluções de grandes massas de capital, provindas de negociações extraordinarias que as actividades funccionaes do commercio não podem comportar e dão lugar a situações ephemeras, a impensados negocios, a temerarios empregos, desconforme com as necessidades, de impossivel sustentação por effeito do refluxo de elementos insubsistentes, temporarios e sem base no funccionamento regular da economia e da riqueza nacional (grifo nosso).

Esta benefica retrocessão aos bons principios, de tão favoreis consequencias para manutenção da ordem nas relações do commercio interno e externo, deve corresponder a profundas alterações no systema do commercio bancario regular, Desde que o thesouro publico deixar de intervir quotidianamente no movimento dos capitaes da praça, a necessidade de superintender ao livre funccionamento da circulação d'esses capitaes, de accôrdo com as 
circumstancias e as necessidades dos mercados, deve determinar a bancos, como este, uma posição especial e acorde com a nova ordem de cousas, tornando-se tanto quanto as boas regras aconselhão, os reguladores discretos da maior ou menor intensidade do movimento do credito. Para isso, cumpre ir dispondo os lineamentos essenciaes, abandonando aos estabelecimentos bancarios de menor vulto e aos banqueiros os negocios de pequena importancia, que requerem por sua natureza exame e conhecimento minuciosos, que o Banco do Brazil não póde dispensar-lhes, e que virão successivamente, fortalecidos pelos credito de respeitaveis intermediarios, tomar o seu lugar na carteira dos grandes bancos.

D’esta reformação no regimen actual, provirão ainda outras vantagens, mórmente a de trazer a administração do banco a uma organisação capaz de assegurar-lhe a continuidade de methodo, de orientação e de responsabilidade, que a sua actual constituição só mui difficilmente lhe pode assegurar.(...)

Não possuindo o Banco do Brazil um trabalho systematicamente organisado neste sentido devemos limitar as nossas observações ás informações do honrado gerente da secção hypothecaria.

Ao ver d'este funccionario os casos de meora produzidos por desidia fraudulenta dos devedores são rarissimos ; os que resultão de má gestão dos negócios não são em grande numero ; avultando entre os retardatarios os que são victimas de embaraços justificados, muitos do quaes, como tem acontecido, vêm a regularisar as suas contas com o auxilio de contemporisação por parte do banco.

Como excepção proveitosa e util aos devedores e ao banco, parecennos razoavel e necessaria uma certa benevolencia ; como regra não.

Nestes casos, e é de crer que sejão em numero de alguma importancia, a complacencia do banco só pôde acarretar perdas para o proprio banco, para os credores subsidiarios, e para o estado geral da agricultura. Para o proprio banco, porque a demasiada contemporisação e a consequente desmoralisação do devedor póde engendrar fraudes ; para os credores subsidiarios, por annullação das garantias absorvidas pelos encargos do devedor impontual ; para o estado geral da agricultura, porque de todas estas perturbações não póde resultar senão o abandono e a relaxação da administração e a consequente depreciação e ruina dos bens agricolas. (p. 6-7).

Acima já verificamos críticas à postura adotada pelo Império em todo o período da pesquisa, de constante interferência às atividades do Banco: aliás, essa foi a linhamestra desde sua fundação em 1808.

Notamos inclusive alguns termos de conotação militar, tais como: funcionamento regular, bons princípios, ordem, boas regras, trabalho systematicamente organisado. 
O relatorio de 1897 traz menção à transição para o vice-presidente da República (BB, 1897):

Graças, porém, á prudencia e tino do Bancos, que bem comprehendendo seus interesses, resolveram conceder prazos e facilitar liquidações a devedores que circumstancias superiores á sua vontade collocaram em posição de não poderem saldar de prompto suas responsabilidades, embora possuidores de recursos na sua Carteira, a crise que ameaçava generalisar-se, foi conjurada. Para tranquilidade dos espiritos, muito contribuio o facto da transmissão do poder ao illustre Vice-Presidente da Republica, sem abalos nem attrictos, que tanto se receiava, ficando assim demonstrado o funccionamento regular das instituições. (p. 10).

Quando da transição política, verificamos a existencia de dois tipos de discurso.

O primeiro em que tenta elucidar as melhorias e benesses das atitudes do atual poder político. Vejamos alguns exemplos (BB, 1897):

Para salvar uma parte dos interesses comprometidos, vê-se a Administração na contingencia de fazer largas concessões aos devedores, o que dá logar ás apreciações infundadas por quem não conhece as difficuldades inherentes a uma liquidação.

Existem negociações pendentes para compra de propriedades do Banco por syndicatos estrangeiros.

$\mathrm{E}^{\prime}$ grato verificar que começa a estabelecer-se uma corrente de capitaes estrangeiros para negocios no Brazil, quer para emprestimos, quer para compra de grandes propriedades agricolas, minas, carris-urbanos, estradas de ferro, etc. Embora ainda timidamente os primeiros passos estão dados e é de esperar que a corrente se accentue.

Pela baixa do cambio, o empregado de dinheiro no Brazil offerece actualmente aos capitalistas estrangeiros larga margem para lucros, desde que se resolvam applical-o em emprezas de larga duração. (p. 11-12).

Já a segunda forma, mais utilizada, é de criar a ideia de que a sua postura é a correta, geralmente denegrindo-se aquele que tinha o poder político anteriormente. Em 1899 são apontados alguns erros anteriores (BB, 1899): 
Para isso, continúa a Administração a empregar todo o zêlo e actividade no manejo prudente e criterioso das novas operações, e a envidar todos os esforços em promover as liquidações de transacções feitas em épocha de irreflectida expansão de credito, oriunda da emissões menos pensadamente applicadas, que tantos desastres causaram a esta praça e ao paiz. (p. 10)

(...) Sob o ponto de vista economico, convém lembrar que o Banco da Republica, oriendo da fusão do Banco do Brazil e do Banco dos Estados Unidos do Brazil, concentrou em sua carteira os residuos de todas as loucuras da Bolsa, para as quaes, convém não esquecer, muito concorreu o Governo com as emissões collossaes do papelmoeda.

No momento actual um dos maiores serviços que se póde prestar á situação economica do paiz é promover a liquidação dos restos de todos os negocios infelizes daquella época desastrada, pois que a nossa situação só póde melhorar eliminando-se a fantasia e assentando todos os negocios em terreno solido e positivo. (grifo nosso) (p. 36)

Porém no ano de 1902 em apresentação aos acionistas, foi efetuada uma varredura na história inteira do Banco, a fim de criticar as atitudes dos poderes políticos anteriores à ascensão dos cafeicultores do sudeste brasileito: um relatorio de quase 200 páginas em que são narradas os desatinos e erros decorrentes, em muito, da ambição e interferência do governo nas operações da instituição financeira.

Abaixo transcrevemos boa parte dele, para a averiguação da extensão e intensidade da crítica efetuada (BB, 1902):

Investidos por S. Ex. o Ministro da Fazenda do encargo da direção do Banco da Republica do Brazil em seu regimen actual, cabe-nos, de conformidade com o art. 12, Titulo V, dos estatutos em vigor, ministrar-vos informações sobre o estado do vosso instituto de credito; abrangendo essas informações o periodo que vae de Outubro de 1900, data em que elle passou á admnistração do Governo, a 31 de Dezembro do anno proximamente findo.

Anno de excepcional gravidade foi, para nó, o ultimo do seculo XIX em que, adiado por tantos annos, se deu o epilogo do jogo desenfreando e das grandes especulações, iniciados n'esta praça logo após a introducção, - por emprestimos ao Estado, ás provincias e a sociedades anonyas oi por aquisição de outras, de consideravel massa de capitaes estrangeiros em 1889, e ao delirio das grandezas provocado por essa torrente de ouro alheio, e exarcebado pelas temerarias emissões de papel-moeda 
em 1890 ; emissão que tiveram infelizes applicações e cujos perniciosos effeitos, pelas transgressões dos principios que regem o credito e a moeda ainda hoje perduram.

Dir-se-hia que, n'essa época, inexplicavel allucinação dominava os espiritos mais reflectidos, não lhes permittindo antever e medir as funestas consequencias a que seriam arrastados pelo esquecimento dos dictames da prudencia.

A idéa dominante era que o paiz tinha, enfim, despertado ; riquezas, até entao latentes, brotariam de todos os ramos de actividade, e o unico meio de exploral-as seria pôr em contribuição não só o pouco, que longos annos de trabalho perseverante accumulára, como o muito que os bancos de emissão lançassem á verocidade, sepre insaciavel, da praça em delirio.

Haviamos chegado, parece, ao periodo aureo : as industrias surgiam de toda a parte; 0 commercio, sob todas as suas fórmas, estava animado de movimento febril, impaciente ; e, á falta de numerario que podesse corresponder a tantas necessidade, as machinas de impressão fabricavam-n'o em escala sempre crescente (grifo nosso). (p. s/n $\mathrm{n}^{\mathrm{o}}$ )

(...) Não tinhamos precisão de reservas, que só o tempo e a prudencia criam: o papel de variegadas côres as substituiriam com a desejada elasticidade ; e, n'esse plano inclinado, o parar seria impossivel, porque não havia calcular a intensidade do primitivo impulso. Estavam - chegou um momento - obliterados todos os canaes da circulação ; a plethora ameaçava provocar perigosas estases, si não se rasgassem novos escoadouros, que drenassem o excesso da producção fiduciaria.

Dava-se, com effeito, o phenomeno curioso, inversão da ordem economica, de andarem os cappitaes de recente creação a inventar empresas, qual d'ellas mais extravagante, sendo as respectivas acções distribuidas e atiradas na praça, vendidas e compradas com maior ou menor agio e reproduzindo-se entre nós as scenas de Pariz, nos tempos de Law.

O Banco do Brazil, segundo d'esse nome, gosando de grande prestigio pelos importantes auxilios ao commercio e ao Estado, velha instituição experimentada na temerosa crise de 1864, estava nas condições de conter esses immoderados impulsos, fugindo ao impensado movimento que lhe poderia comprometter os creditos, si não a propria existencia.

Não o fez; e acompanhando a caudal, transportou para a sua carteira todos os productos elaborados pela especulação. Foi um pernicioso exemplo esse, dado pelo então nosso primeiro estabelecimentode credito, no qual as operações bancarias passaram por transformações radicaes, em que o credito não teve razoaveis limites e os negocios se faziam por massas colossaes, levando-o ás contingencias de não poder prescindir de uma fusão, desastrada para si e para a sua clientela ; sem vantagem, aliás, para o Banco da Republica dos Estados Unidos do Brazil, instituição creada em pleno periodo de delirio e que 
fatalmente tendia a desapparecer com o anniquilamento das phantasias que as suas emissões procrearam e animaram (grifo nosso).

Antes de dar-vos conta da situação actual do vosso estabelecimento e dos actos por nós praticados, na phase presente, julgamos indispensavel examinar as condições em que se achavam os Bancos do Brazil e da Republica dos Estados Unidos do Brazil, da fusão dos quaes, de conformidade com o Decreto n. 1167 de 17 de Dezembro de 1892 e a Lei n.183 C de 23 de Setembro de 1893, resultou o actual Banco da Republica do Brazil.

Faz-se mistér esse exame retrospectivo da situação dos dois institutos, porque é conviç̧ão nossa que n'essa situação estão as causas efficientes do desastre, a que foi arrastada a vossa instituição.

A preoccupação de ministrar-vos dados e esclarecimentos leaes e verdadeiros é o nosso unico objectivo, e diligenciaremos conseguil-o com o espirito de imparcialidade e com a franqueza, que a honestidade, a mais absoluta honestidade das diversas directorias, que se têm succedido na administração do Banco da Republica do Brazil, aos permitte ter e que folgamos de proclamar, para satisfacção propria e dos que, accionistas e credores, têm interesse n'este respeitavel instituto de credito.

Com calma e sem paixão, podemos hoje estudar a extensão das perdas, filhas de erros que são todos, pelas quaes ninguem póde, em rigor, ser responsabilizado, porque, em maior ou menor escala, cada um de nós, na gestão dos proprios interesses, commeteu faltas que, o tempo veio demonstrar, poderiam ter sido evitadas (grifo nosso).

(...) Obedeceremos á seguinte ordem, no relatorio que temos a honra de apresentar-vos:

O Banco do Brazil: -estado e avaliação do seu activo, na época da fusão ; suas responsabilidades ;

O Banco da Republica dos Estados Unidos do Brazil: -analyse do seu activo ; suas responsabilidades ;

Fusão: - vicios que inquinaram desde a origem o Banco da Republica do Brazil ;

Banco da Republica do Brazil: - marcha das liquidações e operações do Banco, desde a fusão até 12 de Stembro de 1900 ;

Banco da Republica do Brazil em sua nova phase: - seu estado por occasião da suspensão de pagamentos; liquidações;

Conta Nova: - carteira commercial e carteira de cambio. (p.7) (...)

CAPITULO I - BANCO DO BRAZIL: -estado e avaliação do seu activo, na época da fusão ; suas responsabilidades.

(...) as contas, tanto do activo como do passivo, - mostram que a antiga instituição, atordoada pelo immoderado impulso que, no decurso d'esse periodo, communicou a todos os negocios o sinistro delirio das grandezas, faltal á ordem financeira e economica do paiz, foi, a pouco e pouco, deixando-se 
contaminar pelo contagio das innovações e dos negocios temerarios, que dominava então todos os espiritos. (grifo nosso) Desde o meado de 1889, começam a surgir as sociedades anonymas e a tomar incremento todos os negocios, fomentados pelas emissões de moeda fiduciaria que, como veremos, abalaram profundamente este estabelecimento, levando-o, com o seu capital, se não de todo perdido, pelo menos seriamente compromettido, á uma situação tal, que parecia insustentavel á propria directoria, já destituido de elementos essenciaes de vida e na impossibilidade, portanto, de preencher os fins de uma instituição de credito.

Parte de 1889 a tendencia immoderada do Banco pelas operacões de credito, que dentro em pouco assumiram gigantescas proporções.

(...)

Esses vastos recursos, trazidos pelos accionistas e pelo publico, não inspiraram, infelizmente, a adopção de uma medida de precaução, que a prudencia reclamava: - a de fortalecer a caixa do Banco, a qual, para ocorrer aos collossaes encargos de seus depositos, dispunha apenas de 9.424:943\$080.

(...) D'este modo, as nuvens carregadas se foram dissipando e não tardou muito que esta grande praça commercial apresentasse novo aspecto - de todo differente e em tudo mais normal ou menos inquietador.

Mas, manda a verdade dizer-vos, que a opinião dos que assignalavam entre as causas da crise - a escassez do meio circulante, tanto mais sensivel quanto mais se ostentava a expansão da actividade commercial, agricola e industrial em todo o paiz ganhou força e, desde as camadas mais elevadas até as mais modestas, constituio-se por fórma a não permitir nenhuma illusão, quanto á necessidade de supprir a circulação do indispensavel instrumento de permuta. (p. 12 e 13).

(...)

O que havia, e que se não podia ver n'aquella época de completo esquecimento das normas de prudencia, é que as grandes entradas de ouro e as temerarias emissões já effectuadas, e, mais do que as emissões, o emprego impremeditado que lhes davam os Bancos, tinham creado um mundo de empresas, para constituição de cujos capitaes se fazia preciso appeliar para os Bancos, de maneira cada vez mais insistentes; tinham gerado necessidades até então ignoradas por nós e agiram sobre o commercio, imprimindo-lhe um movimento facticio pelas compras e vendas a credito, em proporções desarrazoadas.

Não! A inspecção do balanço do Banco prova justamente a exhuberancia do meio circulante, que, não achando mais collocação vantajosa nos descontos e nas cauções, concitou a administração a augmentar o emprego de capitaes disponiveis em acções de bancos e companhias (grifo nosso), elevando a respectiva verba de 2.674:646\$278, em junho de 1889, a 9.316:801\$270 em igual mez de 1890 e empregando mais de um quinto de sua emissão auctorizada (50.000:000\$000 sobre lastro de 
25.000:000\$000 em ouro) em um emprestimo, « baseado na solidez do devedor e na certeza de pontualidade nos pagamentos ajustados », mas evidentemente inconveniente pelo seu longo prazo e avultada importancia (12.000:000\$000), em uma época de « extrema tensão do mercado monetario » ; emprestimo este no qual foi esquecido o criterio abraçado pela administração, de que « a circulação monetária é regulada pelas necessidades das permutas ", fundamento pelo qual se havia escusado de não haver emittido até então (Outubro de 1890) mais de vinte mil contos.

(...)

Pelo rapido augmento de volume das contas correntes com garantia e dos titulos de bancos e companhias que foi adquirido, facil é colligir que as phantasias dos annos anteriores se iam, em marcham accelarada, concentrando na carteira do Banco, absorvendo todos os lucros que o estabelecimento podia auferir, e immobilizando rapidamente os recursos provindos dos depositos e o proprio capital do Banco.

Foram-se accumulando, d'est'arte, no activo do Banco, avolumando-o, todos os elementos capazes de reduzil-o a receptaculo de todos os residuos e impurezas, emanados das grandes especulações. (grifo nosso) (p. 18).

(...)

Propunha-se, pois, uma solução facil, para a qual não eram de mistér complicadas combinações e a que estavam tão affeitos homens do governo, para remediar difficuldades financeiras, creadas pelos mesmos Bancos, com o vezo de dar ao credito uma elasticidade prejudicial aos proprios interesses dos que eram por elle favorecidos.

É natural que a contínua queixa do estado da praça constituisse um logar commum em todos os relatorios, porque nunca se cogitava de renovar e ampliar o capital de giro do Banco, adstricto a contas que jámais se liquidavam, a letras descontadas, umas reformadas com pequenas amortisações, quasi sempre dos juros accrescidos, outras reformadas integralmente, com irreprehensivel pontualidade. (grifo nosso) (p. 20)

(...)

Todas as fontes de proventos para uma instituição de credito funccionavam com actividade prodigiosa, alimentadas, sem uma pausa, sem hesitações, com admiravel precisão, pelos recursos dos depositos, que affluiam de modo altamente lisongeiro aos creditos do Banco, juntos aos que lhe liberalisava o Thesouro, por força da benefica e previdente Lei de Maio de 1875, restabelecida na de Julho de 1885. (p. 21)

(...)

Quaes foram as utilidades positivas, obtidas pelo Banco, de 30 de Junho de 1888 a 31 de Dezembro de 1892 ?

Que vantagens reaes, certas, liquidas, produziu essa massa enorme e complexa de operações, que poucos bancos apresentam em paizes 
mais adiantados, mais bem organizados e de maior movimento commercial e industrial que o nosso? (p. 22).

(...)

(...) negativa, si attendermos não só aos collossaes prejuizos derivados das facilidades de credito prodigalizadas pelo Banco e do desenvolvimento exaggerado de contas correntes garantidas por titulos absolutamente sem valor, como tambem á extrema fraqueza das disponibilidades de caixa, fraqueza que significa perigosa immobilização dos depositos e do capital social, e que, de um para outro momento, poderia exigir o sacrificio de venda precipitada de valores em carteira.

(...) Faremos, em seguida, uma analyse do activo d'este ultimo,de modo a poder formar uma idéa das condições em que se achavam esses dois estabelecimentos, que, reunindo-se, não adquiriam elementos de resistencia, antes deviam caminhar para um desastre, que talvez fosse possivel impedir, mas que os gravissimos erros e inadvertencias commettidos na fusão tornaram inevitavel.

$O$ rapido incremento das contas, constitutivas do activo e das quaes falámos nas linhas precedentes, está a mostrar - ainda mesmo aos que não guardam memoria das phantasias d'aquella época - que outra coisa não exprime esse alinhamento de cifras, que a derivação para a carteira do Banco dos productos de quantas especulações foram engendradas pela mais desenfreada agiotagem. (p. 24).

(...)

Tanto que seja possivel, pelo que vamos dizer, ajuizar d'essa situação, diligenciaremos, descendo a pormenores, patentear a verdadeira devastação que os grandes negocios do periodo passado em revista levaram ao capital bancario, reduzindo-o ás mais mingoadas proporções.

Certamente não haverá exaggero em dar um valor de $75 \%$ ás letras descontadas; um rapido exame d'ellas, seguindo-as atravez os longos mezes em que figuravam em successivas reformas nos livros do Banco, até de todo perderem o valor, nos actoriza, mesmo, a arbitrar-lhes valor mais baixo. (p. 25)

$\mathrm{O}$ resultado, porém, d'este succinto balanço de lucros e perdas, procedentes da liquidação verificada, demonstra que o Banco não tem auferido dos auxilios prestados á lavoura vantagens reaes, que pudessem induzil-o a acceitar novos accôrdos com o Governo; mas que só os realizou para corresponder ao apello feito a seus sentimentos de patriotismo pelo mesmo Governo, que se manifestava então empenhado em debellar a crise do trabalho, com que luctava a lavoura. (p. 27).

(...)

N'esse ramo de operações, só justificaveis pela céga obcessão das idéas então preponderantes, foram esquecidos os conselhos da segurança, acceitando-se em penhor mercantil todos os productos elaborados na tavolagem da bolsa. Acções não integradas de sociedades anonymas incipientes, sem elementos de vida, creadas pela phantasia, sem direção criteriosa, foram 
admittidas a garantir elevadissimos emprestimos; debentures emittidas quase ao mesmo tempo que as acções, tiveram o mais largo acolhimento por parte do Banco, que outra preocupação não parecia nutrir que a de dar vazão ás temerarias emissões auctorizadas (grifo nosso). (p. 48).

(...)

Constituir, por conseguinte, um estabelecimento de credito com a somma dos capitaes dos dois Bancos, sem attender a que esses capitaes estavam seriamente compromettidos, foi erro gravissimo e cujas consequencias, sem a mão forte do Thesouro Federal, seriam muito mais cedo apreciadas, produzindo-se para logo o desastre a que assistimos sete annos mais tarde.

Por outro lado, a systematica distribuição de dividendos de $6 \%$ ao anno sobre um capital que não existia foi exhaurindo as ultimas forças da instituição ; porque esses $6 \%$ tmando por base o capital maximo de 50.000:000\$000, correspondiam a taxas excessivas, a dividendos elevadissimos, que os negocios regulares não podiam custear. (p. 49).

(...)

Assim é que todos esses dividendos, distribuidos desde o inicio do Banco até 30 de Junho de 1900 , perfazem a avultada somma de 53.270:736\$000, em 15 semestres, ou sejam 3.551:382\$400 semestralmente, o que corresponde ao juro annual de $14,25 \%$.

Iniciando as suas operações com um reduzidissimo encaixe e tendo de responder por avultados compromissos, resultantes de depositos que attingiam á grande somma, com o melhor do seo activo immobilizado e de realização difficil, era de prever que a nova instituição iria pesar enormemente sobre o Thesouro, solicitando e obtendo, como aconteceo, constantes supprimentos de fundos, que mais tarde ou edo viriam collocar o Banco ainda em mais precaria situação.

Como si não fosse bastante o erro apontado, adoptou-se outra providencia que, favoravel aos accionistas, cujos interesses foram assim largamente beneficiados, foi altamente lesiva aos credores do Banco, constituindo um verdadeiro attentado, que o decreto da fusão legitimou e que ppassou despercebido aos interessados, si é que os credores dos dois Bancos, deixando de protestar, não entenderam que o Thesouro Federal os indemnisaria dos prejuizos que futuramente soffressem. (p. 50).

(...)

Tudo isso, como se vê, parece irregular : os credores, entre os quaes sobresahia o Thesouro Federal, iam sendo assim esquecidos, e este teria, mais tarde, de supportar todo o peso d'essas operações, que importavam em rateios de capital accionista, com os respectivos juros, sob a fórma de dividendos. (grifo nosso) (p. 51)

(...)

Nosso intuito é simplesmente mostrar que, com os elementos advindos dos dois Bancos fusionados, as administrações que se succederam na direcção do novo Banco, durante o periodo de sete 
annos e meio, não poderiam operar o milagre de impedir a ruina do estabelecimento, eivado de vicios diathesicos profundos, sinão suspendendo, até sua restauração completa, a activas pelo recebimento de acções do proprio Banco, uma vez que se não adoptou a medida radical de reducção do capital á justa medida do seu valor effectivo, eliminando-se a parte que a agiotagem e os excessos de credito dispensado a empresas inviaveis e a individuos sem outros cabedaes que os titulos do encilhamento, tinham absorvido. (p. 54).

(...)

O simples exame dos algarismos em que taes perdas se cifravam estava a mostrar que os dividendos distribuidos em somma approximada de 54.000:000\$000, e que de preferencia deveria ter sido retida para reconstituição do capital, contribuiram em muito para depaupear o organismo da instituição que, não podendo impunentemente ser objecto d'essas sangrias semestraes, viria inevitavelmente a cahir, arrastando em sua ruina os proprios accionistas e compromettendo os interesses dos depositantes. (grifo nosso). (p. 74).

(...)

Para concluir esta parte, que já vai longa, podemos em poucas palavras resumir o que nos foi possivel fazer para minorar os enormes compromissos que gravavam sumir o que nos foi possivel fazer para minorar os enormes compromissos que gravavam a instituição, vencendo as difficuldades proprias de uma epocha, como esta, em que uma crise economica de proporções desconhecidas entre nós, provocou a explosão de uma crise bancaria e commercial até então latente e combatida por meios palliativos, alguns dos quaes se transformaram em agentes do proprio mal, que se tinha em vista debellar.

Temos para nós, que ás falsas noções da moeda e do credito, applicando-se mal a primeira e dando ao segundo as mais funestas proporções, podemos attribuir a serie de desastres que nos têm affligido e cujos effeitos só com o tempo lograremos dissipar.

Essa obra de saneamento, de purificação, na parte que compete a este Banco, não poderia ser emprehendida sem sacrificios e perdas, mais apparentes, entretanto, do que reaes; porque, por um lado, ella elimina o que nada significa ou reduz á realidade o excesso que a fascinação creou, e, por outro, desperta a prudencia, dá aos negocios mais estabilidade e resultados mais positivos e seguros (grifo nosso). (p. 132). 


\section{Conclusão da seção:}

Quando da transição dos diferentes regimes políticos brasileiros ocorridos em tão pequeno espaço de tempo (1889-1894), verificamos dois fenômenos quando falamos das relações entre sociedade civil e sociedade político no tocante ao discurso.

O primeiro corresponde a uma interferência cada vez menor da sociedade política na sua par civil: os tons das críticas e a penetração de termos de cunho republicanos e militares, como vimos mais acima são demonstrações desse evento.

Aqueles rasgados elogios de outrora não eram mais tão frequentes e as críticas, cada vez mais pesadas. De alguma maneira esse enfraquecimento do poder político afetou a sua relação com o Banco, já que aquele apoderamento de outrora na construção da modelagem da opinião público por parte do governo, não é observada.

O segundo fenômeno corresponde na tentativa de construção de seu discurso já na época de desempenho do poder, quer através da crítica (em maior extensão), quer em ideais construtivos, de renovação (em menor extensão).

O Relatório de 1902 é um exemplo disso: em relação à crítica, trazendo à luz uma análise, no seu ponto de vista, "verdadeira e imparcial" nos pontos de falha dos bancos, incluindo o Banco do Brasil à época da fusão.

Faz uma análise minuciosa a fim de atribuir os percalços que sofrera a instituição aos governos anteriores.

Nesse sentido, ocorre o fenômeno inverso do tratado no primeiro ponto, já que o fenômeno observado é um apoderamento da sociedade civil (BB) por parte do Estado para a construção de seu discurso.

Também menciona seu discurso em relação ao novo e para isso, o próprio nascimento do Banco da República do Brasil, com novo nome e "nova história" aparece como exemplo primeiro.

Porém percebemos que nesses dois momentos de transição do poder político, o grupo dominante e o discurso empregado continuam os mesmos: o de servir liberalmente a lavoura, os acionistas e o Governo - confundidos estes com a sociedade brasileira. Em 1894 com Prudente de Morais e mais tarde, coma eleição de Campos Sales do PRP em 1898 há o coroamento da hegemonia do grupo dominante, com o alcance do poder político. 


\section{CAPÍTULO 4 - FINANCIAL REPORTING COMO INSTRUMENTO DE DISSEMINAÇÃO IDEOLÓGICA: ELEMENTOS CONCEITUAIS CONTÁBEIS}

Inúmeras pesquisas tanto nacionais quanto internacionais em outros campos que não a contabilidade, como economia, história, se utilizam de dados contábeis para a confecção de seus estudos.

Contudo, poucos autores se preocupam com a qualidade do número disponibilizado. Quero dizer qualidade como conteúdo informacional em relação ao processo contábil: reconhecimento, mensuração e evidenciação. Será que estes realmente sabem como estão contabilizados tais valores? Eles sabem quais as "políticas e rotinas contábeis adotadas" e qual o impacto desse cenário para suas conclusões?

Nesse sentido, o estudo histórico efetuado por alguém já iniciado em contabilidade pode auxiliar muito na elucidação de algumas questões importantes, como as mencionadas acima.

Diferentemente dos dias atuais, não tínhamos regras contábeis propriamente ditas a serem observadas (Silva, 2005) menciona algumas regulamentações, leis e decretos que impactam ou definem a contabilidade brasileira do século XIX, bem como levanta as obras com algum trecho (ou em sua plenitude) sobre matéria contábil.

Em relação aos dispositivos legais, essencialmente se referem ao método de escrituração, tais como partidas simples, dobradas e livros obrigatórios.

Mas para rotinas e políticas específicas para transações, não temos conhecimento de tais regulamentações.

Falemos brevemente de algumas leis, decretos e regulamentos específicos.

Já no período anterior ao relevante para essa tese, segundo Silva (2005) já tínhamos algumas disposições contábeis, inclusive no ano da chegada da família real com o Decreto de 24 de fevereiro de 1808 sobre a primeira companhia de seguros nacional, que em seu artigo 7.o faz menção à necessidade de "um escriptorio, no qual mercantilmente se façam os precisos e necessarios assentos em livros proprios com limpeza e methodo (...)" (p. 10). 
E em muitos outros alvará, com a criação de órgãos públicos são mencionados os sistemas de escrituração contábil, como a criação do Erário Régio (1808), Conselho de Fazenda (1808), Real Junta de Comércio (1808), Hospital Militar da Corte (1813). No período pós-independência percebe-se um aumento do controle do Governo para com as empresas públicas, bancos e comércio, inclusive com remessas de balancetes mensais, como por exemplo a decisão 93 de 1827 do Ministro e Secretário de Estado dos Negócios da Fazenda e Presidente do Thesouro para as provincias. (Silva, 2005). E posteriormente idem, mas sobretudo requerendo o método das partidas dobradas na escrituração (1828, 1831, 1833,1834, 1835, 1837, 1842, 1850).

Após a primeira metade do século XIX foram verificadas algumas regulamentações no tocante às sociedades anonomias, como por exemplo o decreto 575 de 1849, o decreto 2457 de 1859 e a lei 1083 de 1860, sempre de caráter austero no tocante ao controle do governo. Também relevante o Código Comercial Brasileiro de 1850, com seus dez artigos destinados à contabilidade (Silva, 2005).

No caso dos bancos esse controle era mais grave e severo (Decreto 2457 de 1859) com o demonstrativo semanal a ser enviado à Secretaria do Estado nos Negócios da Fazenda, com composição dos ativos, estado de capital e reservas, bem como todas as emissões e movimentos de ativo e funding. (Silva, 2005).

Inclusive a Lei 1083 de 1860 mantém esse caráter austero no teor coertivo, similar aos decretos e atos institucionais emanados do regime militar brasileiro (1964-1985), segundo Ricardino e Iudícibus (2002).

Os dispositivos da mesma permanceram praticamente inalterados, mesmo com a publicação da nova regulamentação para as sociedades anônimas com a Lei 3150 de 4 de novembro de 1882, complementada pelo decreto 8821 de dezembro de 1882 . (Silva, 2005).

No segundo ponto, buscamos as obras contábeis de época do Brasil para tentar nos ajudar nas questões abaixo levantadas, através das definições e esquemas. Silva (2005\) traz rica pesquisa documental sobre as obras do século XIX.

Com a tentativa de identificar mudanças conceituais e evoluções inerentes à passagem do tempo, usamos como bibliografia dois livros disponíveis: A Metaphysica da Contabilidade Commercial (1837, editado em 1987) de Estevão Raphael de Carvalho e o Tratado Elementar de Contabilidade para Uso dos Alumnos dos Institutos de 
Commercio (1912) de Carlos de Carvalho. Ambos estão disponíveis e foram obtidos na Biblioteca da Faculdade de Economia, Administração e Contabilidade da Universidade de São Paulo (FEA-USP).

Mas o documento que explica algumas, mas não todas, as rotinas e políticas contábeis é o estatuto da empresa, o Banco do Brasil no caso.

A empresa contabilizava discricionariamente elementos importantes de seus livros, com algumas transações, inclusive, de política bem contestável, como veremos nos itens $4.1,4.2$ e 4.3 .

Nesse cenário, a própria interface entre a sociedade civil e a sociedade política, através do Estado Ampliado, permitia uma certa benevolência quanto a quaisquer ruídos nas políticas e práticas contábeis adotadas pelo Banco do Brasil.

Mais importante, o estudo desses temas contábeis permite-nos analisar tanto a causa quanto a consequencia, ou o objetivo, do discurso adotado em todo o período de nossa pesquisa.

Veremos, como conclusão, mais a frente, que nessa época o grupo dominante brasileiro, através de suas diversas camadas de intelectuais, se apropria do financial reporting para o atingimento de seus interesses materiais e de dominação.

Este capítulo está estruturado nas seguintes partes:

A Parte 4.1 que vai discutir o conceito de lucro adotado pelo Banco do Brasil. Será isso mesmo lucro? Comentaremos a questão da remuneração dos diretores e seu tratamento contábil dispensado. Examinaremos as consequências em relação à rentabilidade e dividendos distribuídos.

A Parte 4.2 vai comentar o tratamento contábil dispensado e o impacto sobre a despesa maior importância de todo banco de crédito em qualquer momento da história: a questão dos títulos de liquidação duvidosa. Qual o seu impacto nos números e crescimento do Banco?

A Parte 4.3 vai abordar talvez a questão mais nefasta proporcionada pela sinergia entre a sociedade política e civil para o Banco e para a sociedade brasileira como um todo: o cálculo, a demonstração e o pagamento de dividendos aos acionistas. 


\section{1 - A DEFINIÇÃO DE LUCRO E A REMUNERAÇÃO DOS DIRETORES}

O que é lucro? Para nós, contadores, a resposta é bem simples e direta: a diferença entre as receitas e despesas. Logo para entendermos a definição de lucro, obrigatoriamente devemos saber o que é uma receita e uma despesa. Com isso, conseguimos diferenciar com claridade do outro conceito contábil, patrimônio líquido.

O que diferencia a receita/despesa do patrimônio líquido é sua relação direta com os sócios, já que se houver na transação contábil esse relacionamento, estamos falando de uma transação patrimonial.

Porém um fato muito curioso surge na análise dos relatórios do Banco do Brasil, sobretudo a Demonstração de Lucros e Perdas, a antecedente da atual Demonstração de Resultados: a remuneração/comissão dos diretores.

Segundo os estatutos da instituição que tivemos acesso, a Diretoria tinha direito a 4\% - $6 \%$ de direito de comissão no tocante ao lucro líquido.

Conforme verificado nos relatórios, esse gasto é tratado como redução do patrimônio líquido, não como despesa. Um equivoco conceitual.

Mas será este um erro conceitual, ou apenas uma "questão de época"?

Para isso vejamos que desde 1828, o conceito de despesa, inclusive com sua exemplificação já é conhecido à época, com "segregação extremamente clara do que eram consideradas despesas fixas e variáveis, conforme pode ser observado no corpo do texto (Silva, 2005):

(...) todos os ordenados, soldos, pensões ou vencimentos quaesquer a empregados permanentes e outras despezas fixas e, compreendo-se na segunda todos os jornaes, fornecimentos de armazéns, suprimentos e embarcações do Estado, e finalmente tudo quanto são despezas variáveis, segundo as exigências occorrentes. (p. 19).

Mesmo na bibliografia contábil brasileira, o assunto parece claro. Inclusive na diferenciação desta com o patrimônio dos sócios, a conta capital das obrigações. 
Já em 1837 na Metaphysica da Contabilidade Commercial, Raphael de Carvalho (1987) bem colocava:

21. Durante o giro do negocio, despesas improdutivas, por exemplo, comedorias, alugueis, etc., ha que são indispensaveis de fazer. Ora sendo estas despesas huma quantia que o individuo consome, e que foge d'uma vez para sempre do dominio de seu capital, cumpre saber a quanto ellas montão, a fim de que não reste embaraço, quando houver logar de conhecer o estado de sua fortuna. $\mathrm{O}$ assento das despesas he pois indispensavel. (p. 7).

Em relação ao patrimônio líquido, verificamos nos modelos de balanços e nas peças contábeis obtidas durante as pesquisas documentais, que não havia a segregação específica do passivo com o mesmo, ficando o lado direito de obrigações.

Porém nesse sentido, Raphael de Carvalho (1987) tece alguns comentários à conta capital nos artigos 131 da Metaphysica, principalmente no tocante às suas movimentações:

131. Feita esta operação, o capital toma hum caráter tão particular e reservado, que nehuma outra conta torna a encontra-lo. Entre ellas e elle colloca-se então huma conta que única tem o direito de jogar com elle; he a conta de ganhos e perdas, para por seu intermedio chegar ao grande credor: outro tanto acontece quando qualquer experimenta hum revez, do qual participa o capital, que se empresta a si mesmo risco. Por esta consideração vê-se que o capital he creador de huma potencia; a qual, apenas creada, só pode dirigir-se ao seu chefe supremo pelo intermedio do ministro perdas e ganhos. (p. 63).

(...)

Veja-se o caracter sagrado que apresenta a conta capital! Ella não entra no jogo dos balanços, pois deve ser hum arcano só penetrável pelo negociante. (p. 71).

Mesmo na obra de no Tratado Elementar de Contabilidade de 1912, Carvalho (1912) já coloca a relação da conta capital exclusivamente com os proprietários, no sentido em que "o proprietário deve ter, em primeiro logar, uma conta de capital. Nesta conta se registra o seu haver líquido, a somma de que elle poderá livremente dispor (...).” (p. 
11). O autor continua em relação as contas do proprietário em que são constituídas pelo "capital e todas as contas de renda e despeza, ou de lucros e prejuisos chamadas contas de resultado.” (p. 13).

Mas, nos questionamos? Por que este lançamento está debitando o patrimônio? A resposta pode estar na sua origem, já que pelos Estatutos do Banco, os diretores tem direito a uma parcela do lucro, em torno de $4 \%-5 \%$.

Qual a primeira consequência? Um aumento do lucro, por não ser computada uma despesa relevante. Qual a segunda? Uma diminuição do patrimônio líquido. E qual a terceira, finalmente? Um aumento da rentabilidade, vide que o ROE, por exemplo é a relação entre lucro líquido e patrimônio líquido.

Além disso, vejamos que além dos ordenados mensais e demais benefícios o corpo diretivo tem direito a quase $5 \%$ do lucro anualmente.

Outra consequência é o valor a ser destinado ao Fundo de Reserva, conta de patrimônio, que tinha a função de absorver prejuízos da carteira hipotecaria, que era calculado após a constituição da comissão de diretoria.

Abaixo, elucidamos os efeitos da não-consideração da referida comissão como um elemento de patrimônio e sim de resultado. Quais os impactos na rentabilidade e na constituição do fundo de reserva?

Efetuaremos a análise segregando por década e em seguida, no efeito acumulado no período de 10 anos da pesquisa: 
Tabela 4 - Efeitos da remuneração dos diretores na rentabilidade, constituição de fundo de reserva e distribuição de dividendos para os anos bancais de 1850 (em réis-mil)

\begin{tabular}{|c|c|c|c|c|c|c|c|}
\hline & 1854 & 1855 & 1856 & 1857 & 1858 & 1859 & Anos 1850 \\
\hline Lucro líquido divulgado & 1.332 .833 & 1.870 .136 & 2.552 .061 & 2.552 .461 & 4.436 .241 & 3.037 .965 & 15.781 .698 \\
\hline (-) Comissão para diretores & 49.912 & 69.621 & 113.585 & 113.585 & 177.450 & 121.519 & 645.671 \\
\hline (=) Lucro líquido ajustado & 1.282 .922 & 1.800 .515 & 2.438 .476 & 2.438 .876 & 4.258 .791 & 2.916 .447 & 15.136 .026 \\
\hline \multicolumn{8}{|l|}{ Efeitos em \% } \\
\hline Relativos aos lucros e distribuição de dividendos & $-3,74 \%$ & $-3,72 \%$ & $-4,45 \%$ & $-4,45 \%$ & $-4,00 \%$ & $-4,00 \%$ & $-4,09 \%$ \\
\hline Relativo à constituição do fundo de reserva & $-3,35 \%$ & $-2,76 \%$ & $-4,45 \%$ & $-4,43 \%$ & $-3,65 \%$ & $-3,98 \%$ & $-3,84 \%$ \\
\hline Relativo ao ROE & $-0,15$ p.p. & $-0,20 p \cdot p$. & $-0,30$ p.p. & $-0,30$ p.p. & $-0,40$ p.p. & $-0,31$ p.p. & n/a. \\
\hline \multicolumn{8}{|l|}{ Efeitos absolutos } \\
\hline Fundo de reserva divulgado $(6 \%)$ & 79.647 & 111.097 & 153.124 & 153.122 & 265.208 & 182.247 & 944.444 \\
\hline Fundo de reserva ajustado (6\%) & 76.975 & 108.031 & 146.309 & 146.333 & 255.527 & 174.987 & 908.162 \\
\hline Dividendos divulgados & 1.202 .300 & 1.688 .000 & 2.282 .400 & 2.282 .400 & 3.962 .100 & 2.679 .000 & 14.096 .200 \\
\hline Dividendos ajustados & 1.157 .276 & 1.625 .160 & 2.180 .817 & 2.180 .833 & 3.803 .616 & 2.571 .840 & 13.519 .542 \\
\hline ROE divulgado & $4,41 \%$ & $6,07 \%$ & $8,00 \%$ & $7,99 \%$ & $13,46 \%$ & $9,38 \%$ & $\mathrm{n} / \mathrm{a}$ \\
\hline ROE ajustado & $4,25 \%$ & $5,87 \%$ & $7,69 \%$ & $7,69 \%$ & $13,05 \%$ & $9,07 \%$ & $\mathrm{n} / \mathrm{a}$ \\
\hline
\end{tabular}

A análise dos anos de 1850, iniciada com o ano bancal de 1854 evidencia, além do pagamento dos ordenados mensais aos diretores da instituição, havia essa gratificação que diferentemente daquela era debitada ao patrimônio e não ao resultado na ordem de $4 \%$ a.a.

Retirando os efeitos de tal remuneração do lucro líquido, mantendo, assim, uniformidade conceitual e por conseguinte de tratamento contábil, verificamos que mesmo de valores relativamente pequenos em relação ao lucro gerado pela instituição, a distribuição de dividendos aos acionistas seria menor na ordem entre $3,72 \%$ e $4,45 \%$ daquele que fora de fato pago à época.

Na mesma direção a constuição do fundo de reserva também seria afetado, já que o lucro base para o seu cálculo seria também reduzido. Assim, nos anos de 1850, verificamos que caso fosse considerada despesa a gratificação à administração, o fundo de reserva contabilizado seria menor entre $2,76 \%$ e $4,45 \%$ do real. 
A rentabilidade vista sob a ótica do patrimônio liquido contábil (ROE) também é afetada pela tratativa dispensada à remuneração supracitada. Nos anos componentes de 1850 , diminuiria na faixa de .10 p.p. e .40 p.p.

Verifica-se pois como seria afetada a instituição e seus principais componentes (acionistas, diretoria e governo), apenas desconsiderando esse efeito "contábil". Teriam seus rendimentos anuais, já diminutos em sua visão como verificamos na análise do discurso (Partes 3.1 e 3.2).

Tabela 5 - Efeitos da remuneração dos diretores na rentabilidade, constituição de fundo de reserva e distribuição de dividendos para os anos bancais de 1860 (em réis-mil)

\begin{tabular}{|c|c|c|c|c|c|c|c|c|c|c|c|}
\hline & 1860 & 1861 & 1862 & 1863 & 1864 & 1865 & 1866 & 1867 & 1868 & 1869 & Anos 1860 \\
\hline Lucro líquido divulgado & 3.037 .445 & 2.919 .444 & 2.572 .730 & 3.307 .372 & 3.194 .918 & 4.806 .443 & 6.014 .768 & 6.476 .288 & 5.642 .834 & 4.813 .871 & 42.670 .650 \\
\hline (-) Comissão para diretores & 145.999 & 136.647 & 126.519 & 165.805 & 163.307 & 203.120 & 248.068 & 200.504 & 125.400 & 653.800 & 2.169 .169 \\
\hline (=) Lucro líquido ajustado & 2.891 .446 & 2.782 .796 & 2.446 .211 & 3.141 .567 & 3.031 .611 & 4.603 .323 & 5.766 .700 & 6.275 .783 & 5.517 .434 & 4.160 .071 & 40.501 .481 \\
\hline \multicolumn{12}{|l|}{ Efeitos em \% } \\
\hline $\begin{array}{l}\text { Relativos aos lucros e } \\
\text { distribuição de dividendos }\end{array}$ & $-4,81 \%$ & $-4,68 \%$ & $-4,92 \%$ & $-5,01 \%$ & $-5,11 \%$ & $-4,23 \%$ & $-4,12 \%$ & $-3,10 \%$ & $-2,22 \%$ & $-13,58 \%$ & $-5,08 \%$ \\
\hline $\begin{array}{l}\text { Relativo à constituição do } \\
\text { fundo de reserva }\end{array}$ & $-4,81 \%$ & $-3,68 \%$ & $-4,85 \%$ & $-4,80 \%$ & $-2,47 \%$ & $-1,54 \%$ & $-0,76 \%$ & $-19,81 \%$ & $-29,31 \%$ & $-36,15 \%$ & $-17,81 \%$ \\
\hline Relativo ao ROE & $-0,37$ p.p. & $-0,35$ p.p. & $-0,33$ p.p. & $-0,38$ p.p. & $-0,38$ p.p. & $-0,42$ p.p. & $-0,49$ p.p. & $-0,18$ p.p. & 0,00.p. & $-1,20$ p.p. & $\mathrm{n} / \mathrm{a}$ \\
\hline \multicolumn{12}{|l|}{ Efeitos absolutos } \\
\hline $\begin{array}{l}\text { Fundo de reserva divulgado } \\
(6 \%)\end{array}$ & 182.247 & 173.344 & 154.247 & 197.991 & 186.508 & 965.644 & 2.136 .700 & 2.315 .783 & 2.382 .434 & 1.725 .071 & 10.419 .969 \\
\hline $\begin{array}{l}\text { Fundo de reserva ajustado } \\
(6 \%)\end{array}$ & 173.487 & 166.968 & 146.773 & 188.494 & 181.897 & 950.726 & 2.120 .498 & 1.856 .938 & 1.684 .032 & 1.101 .473 & 8.564 .356 \\
\hline Dividendos divulgados & 2.679 .000 & 2.608 .500 & 2.289 .840 & 2.937 .000 & 2.887 .500 & 3.630 .000 & 3.630 .000 & 3.960 .000 & 3.135 .000 & 2.970 .000 & 30.726 .840 \\
\hline Dividendos ajustados & 2.550 .230 & 2.486 .407 & 2.177 .233 & 2.789 .763 & 2.739 .907 & 3.476 .596 & 3.480 .288 & 3.837 .399 & 3.065 .331 & 2.566 .627 & 29.164 .836 \\
\hline ROE divulgado & $9,40 \%$ & $9,07 \%$ & $7,95 \%$ & $9,18 \%$ & $8,85 \%$ & $12,70 \%$ & $15,98 \%$ & $16,94 \%$ & $14,49 \%$ & $12,36 \%$ & $\mathrm{n} / \mathrm{a}$ \\
\hline ROE ajustado & $9,03 \%$ & $8,72 \%$ & $7,62 \%$ & $8,80 \%$ & $8,47 \%$ & $12,28 \%$ & $15,49 \%$ & $16,76 \%$ & $14,49 \%$ & $11,16 \%$ & $\mathrm{n} / \mathrm{a}$ \\
\hline
\end{tabular}

Com os anos bancais da década de 60 , verificamos que os lucros e dividendos seriam menores na razão de $2,22 \%$ e $13,58 \%$, caso a remuneração da direção fosse tratada como despesa do exercício bancal. Esse último decréscimo de 13,58\% é ocorrido devido ao pagamento na ordem de 653.800\$000 em 1869 aos administradores. Mas desconsiderando esse exercício atípico, os lucros e dividendos seriam menores entre $2,22 \%$ e $5,11 \%$ nesse período. 
Já as constituições dos fundos de reserva sofrem uma alteração importante já que após 1865 são contabilizados valores adicionais nessa rubrica para facer face à eventuais prejuizos, como já verificamos mais acima. Nos números ajustados de fundos de reserva apresentados na Tabela $\mathrm{Y}$, consideramos as adicionais divulgadas separadamente nas demonstrações da conta ganhos e perdas da instituição e o valor estipulado pelos estatutos dos respectivos anos de $6 \%$. Logo, a variação a menor se situa entre $0,76 \%$ e $36,15 \%$ nos anos de 1860 .

Na mesma direção se comportou o ROE que variou entre nulo (0p.p) e -1,2p.p nos anos de 1860, este último devido ao motivo citado no parágrafo anterior.

Tabela 6 - Efeitos da remuneração dos diretores na rentabilidade, constituição de fundo de reserva e distribuição de dividendos para os anos bancais de 1870 (em réis-mil)

\begin{tabular}{|c|c|c|c|c|c|c|c|c|c|c|c|}
\hline & 1870 & 1871 & 1872 & 1873 & 1874 & 1875 & 1876 & 1877 & 1878 & 1879 & Anos 1870 \\
\hline Lucro líquido divulgado & 5.331 .642 & 4.988 .325 & 4.439 .432 & 4.697 .572 & 4.615 .113 & 4.475 .030 & 4.363 .247 & 5.294 .977 & 4.841 .969 & 4.337 .244 & 47.384 .551 \\
\hline (-) Comissão para diretores & 118.800 & 75.900 & 66.000 & 66.000 & 66.000 & 71.125 & 74.643 & 80.094 & 81.218 & 78.122 & 777.901 \\
\hline (=) Lucro líquido ajustado & 5.212 .842 & 4.912 .425 & 4.373 .432 & 4.631 .572 & 4.549 .113 & 4.403 .906 & 4.288 .604 & 5.214 .883 & 4.760 .751 & 4.259 .122 & 46.606 .650 \\
\hline \multicolumn{12}{|l|}{ Efeitos em \% } \\
\hline $\begin{array}{l}\text { Relativos aos lucros e } \\
\text { distribuição de dividendos }\end{array}$ & $-2,23 \%$ & $-1,52 \%$ & $-1,49 \%$ & $-1,40 \%$ & $-1,43 \%$ & $-1,59 \%$ & $-1,71 \%$ & $-1,51 \%$ & $-1,68 \%$ & $-1,80 \%$ & $-1,64 \%$ \\
\hline $\begin{array}{l}\text { Relativo à constituição do } \\
\text { fundo de reserva }\end{array}$ & $-29,01 \%$ & $-26,63 \%$ & $-30,96 \%$ & $-28,50 \%$ & $-29,22 \%$ & $-33,85 \%$ & $-35,59 \%$ & $-28,52 \%$ & $-32,72 \%$ & $-40,74 \%$ & $-30,92 \%$ \\
\hline Relativo ao ROE & $-0,01 p \cdot p$ & 0,02p.p. & 0,01 p.p. & 0,04 p.p. & 0,04p.p. & 0,02p.p. & 0,00p.p. & 0,04p.p. & 0,00p.p. & $-0,03 p . p$ & $\mathrm{n} / \mathrm{a}$ \\
\hline \multicolumn{12}{|l|}{ Efeitos absolutos } \\
\hline $\begin{array}{l}\text { Fundo de reserva divulgado } \\
(6 \%)\end{array}$ & 2.242 .842 & 2.272 .425 & 1.733 .432 & 1.991 .573 & 1.909 .113 & 1.598 .906 & 1.483 .604 & 2.244 .883 & 1.790 .751 & 1.289 .122 & 18.556 .651 \\
\hline $\begin{array}{l}\text { Fundo de reserva ajustado } \\
(6 \%)\end{array}$ & 1.592 .263 & 1.667 .367 & 1.196 .740 & 1.423 .903 & 1.351 .339 & 1.057 .635 & 955.536 & 1.604 .680 & 1.204 .842 & 763.965 & 12.818 .271 \\
\hline Dividendos divulgados & 2.970 .000 & 2.640 .000 & 2.640 .000 & 2.640 .000 & 2.640 .000 & 2.805 .000 & 2.805 .000 & 2.970 .000 & 2.970 .000 & 2.970 .000 & 28.050 .000 \\
\hline Dividendos ajustados & 2.903 .822 & 2.599 .831 & 2.600 .752 & 2.602 .908 & 2.602 .246 & 2.760 .418 & 2.757 .014 & 2.925 .075 & 2.920 .182 & 2.916 .505 & 27.589 .510 \\
\hline ROE divulgado & $13,83 \%$ & $11,69 \%$ & $10,92 \%$ & $12,28 \%$ & $12,22 \%$ & $11,86 \%$ & $11,19 \%$ & $12,69 \%$ & $11,50 \%$ & $10,08 \%$ & $\mathrm{n} / \mathrm{a}$ \\
\hline ROE ajustado & $13,82 \%$ & $11,71 \%$ & $10,93 \%$ & $12,33 \%$ & $12,26 \%$ & $11,88 \%$ & $11,18 \%$ & $12,73 \%$ & $11,51 \%$ & $10,05 \%$ & $\mathrm{n} / \mathrm{a}$ \\
\hline
\end{tabular}

Nos anos de 1870, após aquele pagamento importante aos diretores em 1869 e agora, em 1870, mais um não tão aumentativo, mas bem acima da média e também acima do determinando em seus estatutos de $118.800 \$ 000$. Também a se destacar a variação alta no fundo de reserva constituído, quando comparados os reais e os ajustados, 
devido a contabilização de valores adicionais para absorção de perdas na carteira em todos os anos de 1870 .

Consequentemente, verificamos que os lucros e dividendos (reais e ajustados) se manteriam em uma mesma faixa com variação situando-se entre $-1,40 \%$ e $-2,23 \%$, fato esse que implica em ROEs praticamente similares. Mas percebamos que o efeito da crise dos anos 60 já se faz sentida na rentabilidade da instituição que supera a marca dos $10 \%$ em todos os anos bancais. Mas gerou insatisfação em seus acionistas já que seu retorno foi inclusive menor que na década de 60 , no auge da crise.

Tabela 7 - Efeitos da remuneração dos diretores na rentabilidade, constituição de fundo de reserva e distribuição de dividendos para os anos bancais de 1880 (em réis-mil)

\begin{tabular}{|c|c|c|c|c|c|c|c|c|c|c|c|}
\hline & 1880 & 1881 & 1882 & 1883 & 1884 & 1885 & 1886 & 1887 & 1888 & 1889 & Anos 1880 \\
\hline Lucro líquido divulgado & 4.937 .822 & 4.590 .658 & 4.820 .191 & 5.061 .200 & 5.119 .836 & 3.895 .202 & 3.854 .652 & 4.325 .558 & 3.289 .265 & 3.551 .608 & 43.445 .991 \\
\hline (-) Comissão para diretores & 86.336 & 82.500 & 82.500 & 82.500 & 82.500 & 70.125 & 70.125 & 74.250 & 74.250 & 51.040 & 756.126 \\
\hline$(=)$ Lucro líquido ajustado & 4.851 .486 & 4.508 .158 & 4.737 .691 & 4.978 .700 & 5.037 .336 & 3.825 .077 & 3.784 .527 & 4.251 .308 & 3.215 .015 & 3.500 .568 & 42.689 .865 \\
\hline \multicolumn{12}{|l|}{ Efeitos em \% } \\
\hline $\begin{array}{l}\text { Relativos aos lucros e } \\
\text { distribuição de dividendos }\end{array}$ & $-1,75 \%$ & $-1,80 \%$ & $-1,71 \%$ & $-1,63 \%$ & $-1,61 \%$ & $-1,80 \%$ & $-1,82 \%$ & $-1,72 \%$ & $-2,26 \%$ & $-1,44 \%$ & $-1,74 \%$ \\
\hline $\begin{array}{l}\text { Relativo à constituição do } \\
\text { fundo de reserva }\end{array}$ & $-38,53 \%$ & $-77,61 \%$ & $-77,59 \%$ & $-77,57 \%$ & $-82,60 \%$ & $-77,50 \%$ & $-76,82 \%$ & $-80,09 \%$ & $-77,17 \%$ & $-75,59 \%$ & $-73,32 \%$ \\
\hline Relativo ao ROE & 0,00p.p. & 0,07p.p. & 0,10p.p. & 0,13p.p. & $0,24 p . p$. & 0,03p.p. & 0,03p.p. & 0,11 p.p. & $-0,03 p . p$ & 0,03p.p. & $\mathrm{n} / \mathrm{a}$ \\
\hline \multicolumn{12}{|l|}{ Efeitos absolutos } \\
\hline $\begin{array}{l}\text { Fundo de reserva divulgado } \\
(6 \%)\end{array}$ & 1.551 .486 & 1.208 .158 & 1.268 .566 & 1.331 .994 & 1.737 .336 & 1.020 .077 & 979.527 & 1.281 .308 & 845.015 & 860.568 & 12.084 .034 \\
\hline $\begin{array}{l}\text { Fundo de reserva ajustado } \\
(6 \%)\end{array}$ & 953.768 & 270.489 & 284.261 & 298.722 & 302.240 & 229.505 & 227.072 & 255.078 & 192.901 & 210.034 & 3.224 .070 \\
\hline Dividendos divulgados & 3.300 .000 & 3.300 .000 & 3.300 .000 & 3.300 .000 & 3.300 .000 & 2.805 .000 & 2.805 .000 & 2.970 .000 & 2.370 .000 & 2.640 .000 & 30.090 .000 \\
\hline Dividendos ajustados & 3.242 .301 & 3.240 .695 & 3.243 .519 & 3.246 .208 & 3.246 .824 & 2.754 .502 & 2.753 .971 & 2.919 .019 & 2.316 .501 & 2.602 .061 & 29.565 .600 \\
\hline ROE divulgado & $11,37 \%$ & $10,55 \%$ & $11,08 \%$ & $11,64 \%$ & $11,65 \%$ & $9,23 \%$ & $9,43 \%$ & $10,37 \%$ & $7,81 \%$ & $8,78 \%$ & $\mathrm{n} / \mathrm{a}$ \\
\hline ROE ajustado & $11,37 \%$ & $10,63 \%$ & $11,18 \%$ & $11,76 \%$ & $11,89 \%$ & $9,26 \%$ & $9,46 \%$ & $10,48 \%$ & $7,78 \%$ & $8,81 \%$ & $\mathrm{n} / \mathrm{a}$ \\
\hline
\end{tabular}

$\mathrm{Na}$ década da abolição da escravatura, verificamos que a instituição passa a contabilizar fundos de reserva de maneira não segregada, isto é, classificando separadamente aquela estipulada em seus estatutos daquelas adicionais. Assim sendo, a constituição do fundo de reserva em nossos ajustes contém apenas aquele evidenciado (6\%). Esse fato implica na constituição desse fundo que tem variância importante, com um mínimo de $-38,53 \%$ em 1880, ano último em que havia a classificação separada e, -80,09\% em 1888 ano da abolição. 
Os lucros e dividendos distribuídos novamente seriam diminuídos numa faixa de $1,44 \%$ e $-1,82 \%$ caso a remuneração dos diretores fossem tratadas como despesas do ano bancal.

Nessa direção aquela reclamação dos acionistas nos anos de 1870 agora fora atendida já que seus dividendos voltaram aos níveis da década anterior, mesmo com todas as dificuldades causadas pelo ato de abolição e a queda da rentabilidade da instituição, que nos anos próximos à assinatura da lei Áurea voltam aos níveis do período da crise bancária dos anos 60 .

Tabela 8 - Efeitos da remuneração dos diretores na rentabilidade, constituição de fundo de reserva e distribuição de dividendos para os anos bancais de 1890 a 1893 (em réis-mil)

\begin{tabular}{|c|c|c|c|c|}
\hline & 1890 & 1891 & 1892 & 1893 \\
\hline Lucro líquido divulgado & 6.016 .132 & 12.970 .968 & 15.964 .741 & 4.784 .340 \\
\hline (-) Comissão para diretores & 66.585 & 157.275 & 159.600 & - \\
\hline (=) Lucro líquido ajustado & 5.949 .547 & 12.813 .693 & 15.805 .141 & 4.784 .340 \\
\hline \multicolumn{5}{|l|}{ Efeitos em \% } \\
\hline Relativos aos lucros e distribuição de dividendos & $-1,11 \%$ & $-1,21 \%$ & $-1,00 \%$ & $0,00 \%$ \\
\hline Relativo à constituição do fundo de reserva & $-76,37 \%$ & $-7,93 \%$ & $-76,29 \%$ & $-84,97 \%$ \\
\hline Relativo ao ROE & 0,00 p.p. & $-0,08$ p.p. & 0,14p.p. & $\mathrm{n} / \mathrm{a}$ \\
\hline \multicolumn{5}{|l|}{ Efeitos absolutos } \\
\hline Fundo de reserva divulgado $(6 \%)$ & 1.510 .547 & 2.328 .676 & 4.000 .000 & 1.909 .401 \\
\hline Fundo de reserva ajustado (6\%) & 356.973 & 2.144 .099 & 948.308 & 287.060 \\
\hline Dividendos divulgados & 4.439 .000 & 10.485 .018 & 10.640 .000 & 7.952 .952 \\
\hline Dividendos ajustados & 4.389 .870 & 10.357 .885 & 10.533 .632 & 7.952 .952 \\
\hline ROE divulgado & $5,10 \%$ & $9,11 \%$ & $10,94 \%$ & $2,03 \%$ \\
\hline ROE ajustado & $5,09 \%$ & $9,03 \%$ & $11,09 \%$ & $2,04 \%$ \\
\hline
\end{tabular}

Nos anos primeiros da República, a entidade continua a utilizar a mesma prática de contabilizar fundos de reserva sem distinção de sua categoria, o que implica na distribuição dos números ajustados apenas daqueles permitidos em seus estatutos.

Com a reorganização societária promovida nos anos 90 e consequente aumento de capital adicionados às crises sociais e econômicas, a rentabilidade da instituição sofre 
no primeiro ano mas retoma no segundo, com distribuição novamente avultada de dividendos.

Assim, o ROE que parte de 5,10\% em 1890 vai a 10,94\% em 1892, indo a mínima de 2,03\% em 1893 devido ao aumento de capital ocorrida neste ano e o fraco desempenho operacional do banco. Comparando-se com os ajustados, o ROE, lucros e dividendos permaneceriam numa faixa similar, com pequena redução situada entre .08 p.p. e .14 p.p. para o ROE e $-1,21 \%$ e zero para lucro e dividendos. 


\section{2 - A PRINCIPAL DESPESA DE UM BANCO: OS TÍTULOS DUVIDOSOS}

Como a função do banco é fornecer crédito, é sabido que muitos devedores não honrem seus compromissos, ainda mais em períodos de crise como os últimos cinquenta anos dos Oitocentos.

Porém não é efetuada nenhuma divulgação acerca da contabilização como despesa (ou não) desses eventos. Há apenas descrições breves sobre poucos casos de falências (apenas um parágrafo, em muitos casos).

O único lançamento contábil efetuado era a saída da carteira (normal) a crédito e debitando-se a rubrica chamada títulos em liquidação.

Quando efetuados todos os esforços para a cobrança dos títulos já vencidos era efetuada a transferência ou a absorção pela conta de patrimônio Fundo de Reserva. Vejamos então que uma perda na carteira, não transitava nunca pelo resultado, não afetando o lucro, e por conseguinte, a distribuição de dividendos aos acionistas, nem a comissão dos diretores.

A própria transferência para as contas tanto de "Títulos em Liquidação" como "Fundo de Reserva" não respeitava nenhuma "regra", ficando à mercê da tempestividade desejada pela Administração do Banco.

Como vimos na seção acima, a descrição conceitual da despesa já existia (Raphael de Carvalho, 1987):

22. Se algum artigo do negocio fôr arruinado ou extraviado por qualquer accidente que seja, o valor delle deve figurar ao lado das despesas improductivas (21) ou perdas.

23. Se o individuo, em vez de empregar em effeitos todo o seu capital, emprestar parte delle mediante algum beneficio, como este seja sempre hum ganho, do mesmo modo que as despesas acima (21) são perdas, não só he indispensável assentar a quantia emprestada, como o juro ou benefício que fôr produzindo. (p. 7).

Vemos que Raphael de Carvalho já nos anos 30 (1837) deixa bem claro a existencia conceitual das despesas inclusive na visão de fornecimento pecuniário, como no item 
23, que na situação análoga, porém contrária ao ganho, a perda ou malefício causado também deveria ser refletido como despesa improductiva.

Vemos adicionalmente que mesmo a questão da dúvida em relação ao recebimento de um item não implicava necessariamente na sua não contabilização, já que de acordo com Raphael de Carvalho (1987), “(...) o fiado encerre certo gráo de probabilidade duvidosa para o recebimento, elle espera então para levar essa quantia ao assento respectivo, como se fôra à vista.” (p. 20)., isto é, lançando-se ou assentando uma despesa.

Essa visão é reforçada nos artigos 89 e 92 da Metaphysica (Raphael de Carvalho, 1987):

89. Outro elemento da contabilidade vem a ser os ganhos e perdas; aquelles são valores recebidos, estas são quantias dadas, extraviadas ou consumidas. E pois o fim do negocio seja o lucro (13) e este só appareça depois de deduzidos os prejuisos, naturalmente nasce a conta de ganhos e perdas. (p. 38) (...)

92. (...) De modo que, quer quando dá, quer quando recebe, como isto seja sempre por troca de outro gênero, inclusive o dinheiro, assim á vista como a tempo, segue-se que sempre mais de huma conta tem que ser considerada; não exceptuando os casos em que se ganha ou perde alguma coisa, porque a conta a que essa cousa pertencer, vai jogar com a de ganhos e perdas. (p. 39)

A própria tratativa conceitual contábil é dada por Carvalho (1912) no sentido em que "na transformação de um activo em um de menor valor (...)", "debita-se a despeza e credita-se a conta de quem pagou a importância.” (p. 34).

Mais a frente a clareza fica evidente, quando Carvalho (1912) afirma que "si ha prejuizo na liquidação o prejuizo é debitado á conta Lucros e Perdas.” (p. 49).

Inclusive no capítulo sobre contabilidade bancária, Carvalho ensina que o uso da conta "Fundo de Reservas" deve ser apenas para prejuízos extraordinários, eventuais, (Carvalho, 1912) bem diferente de perdas no recebimento de créditos quando se trata de uma instituição financeira. 
Sua função, como bem pontua Carvalho (1912), é "geralmente fazer face aos prejuizos eventuais, de modo que o capital não seja tocado.” (p. 322).

Agora apresentaremos o efeito da não contabilização como despesa das perdas estimadas com a carteira de crédito para o Banco do Brasil no tocante à lucratividade e distribuição de dividendos no período de 1853 a 1900, separando pelo período de 10 anos compreendidos.

A proxy que utilizamos para a despesa para devedores duvidosos foi a constituição do fundo de reserva no período, já que o caminho natural das perdas na carteira de crédito da instituição transitavam diretamente para a referida conta e nos exercícios imediatamente subsequentes eram consumidas e lançadas novas, que também no próximo exercício eram revertidas, isto é, utilizadas.

Tabela 9 - Efeitos da contabilização do fundo de reserva no patrimônio na rentabilidade e distribuição de dividendos para os anos bancais de 1850 (em réis-mil)

\begin{tabular}{|c|c|c|c|c|c|c|c|}
\hline & 1854 & 1855 & 1856 & 1857 & 1858 & 1859 & Anos 1850 \\
\hline Lucro líquido divulgado & 1.332 .833 & 1.870 .136 & 2.552 .061 & 2.552 .461 & 4.436 .241 & 3.037 .965 & 15.781 .698 \\
\hline (-) Costituição de fundo de reserva & 79.647 & 111.097 & 153.124 & 153.122 & 265.208 & 182.247 & 944.444 \\
\hline (=) Lucro líquido ajustado & 1.253 .187 & 1.759 .039 & 2.398 .937 & 2.399 .339 & 4.171 .033 & 2.855 .719 & 14.837 .254 \\
\hline \multicolumn{8}{|l|}{ Efeitos em \% } \\
\hline Relativos aos lucros e distribuição de dividendos & $-5,98 \%$ & $-5,94 \%$ & $-6,00 \%$ & $-6,00 \%$ & $-5,98 \%$ & $-6,00 \%$ & $-5,98 \%$ \\
\hline Relativo ao ROE & $-0,23$ p.p. & $-0,30$ p.p. & $-0,37$ p.p. & $-0,37$ p.p. & $-0,50$ p.p. & $-0,42$ p.p. & $\mathrm{n} / \mathrm{a}$ \\
\hline \multicolumn{8}{|l|}{ Efeitos absolutos } \\
\hline Dividendos divulgados & 1.202 .300 & 1.688 .000 & 2.282 .400 & 2.282 .400 & 3.962 .100 & 2.679 .000 & 14.096 .200 \\
\hline Dividendos ajustados & 1.130 .454 & 1.587 .723 & 2.145 .456 & 2.145 .479 & 3.725 .237 & 2.518 .288 & 13.252 .636 \\
\hline ROE divulgado & $4,41 \%$ & $6,07 \%$ & $8,00 \%$ & $7,99 \%$ & $13,46 \%$ & $9,38 \%$ & $\mathrm{n} / \mathrm{a}$ \\
\hline ROE ajustado & $4,17 \%$ & $5,77 \%$ & $7,62 \%$ & $7,62 \%$ & $12,95 \%$ & $8,96 \%$ & $\mathrm{n} / \mathrm{a}$ \\
\hline
\end{tabular}

No item anterior, quando examinados os efeitos da remuneração dos diretores no patrimônio da instituição, percebemos a dimensão diminuta nos períodos estudados.

Porém o assunto se torna mais delicado quando falamos da principal despesa de uma instituição financeira, a questão com as perdas estimadas da carteira. 
Nos anos de 1850, percebemos que o lucro e por conseguinte a distribuição de dividendos seriam razoavelmente menores caso fosse adotada a prática da contabilização como despesa. Em média foram pagos dividendos $6 \%$ maiores durante esses primeiros anos. Verificamos, pois, que o banco praticamente foi comprometido em 50\% do seu capital social (14.096.200\$000 de 33.000.000\$000) e praticamente a totalidade do lucro majorado com a não contabilização dos títulos duvidosos (14.096.200\$000 de 15.781.697\$518) já nesses primeiros seis anos de existência, com a transferência de recursos a título de dividendos.

O ROE acompanha esse raciocínio, variando na ordem de negativos .23p.p. a .50 p.p. no período.

Nos relatórios do banco da época há uma série de menções aos problemas com as contrapartes, sobretudo nos casos de falências dos devedores.

Comecemos em 1857 (BB, 1857):

A declaração de fallencia da firma commercial de Araujo Braga \& Oliveira, trouxe a de outras firmas que com aquella erão coobrigadas por Letras que existião no Banco: a importancia dessa responsabilidade collectiva que na occasião da fallencia subia a Rs. 134.000\$ acha-se reduzida a Rs. 92.914\$, em consequencia de haverem sido pagas algumas Letras por terceiros endossadas. Não será possível desde já calcular o prejuizo que o Banco tem de soffrer, mas he de esperar que os rateios a receber pelas liquidações das massas dos fallidos diminuão muito aquelle algarismo. (p. 10)

No ano bancal de 1858, temos (BB, 1858):

No anno passado deu-vos conta o relatorio do fallimento da firma social de Araújo Braga e Oliveira, ficando por liquidar ainda a somma de 92:914\$000. Achão-se ainda pendentes em juizo os processos a que deu occasião esta fallencia, e espera-se receber o rateio de hum dos socios que obteve concordata de seus credores.

Sendo a Directoria de anunciar-vos este anno sucessos ainda mais desastrosos, não só pela sua importancia, como pelo nexo em que se acharão com muitas e importantes casas (...).

Nutro, porém, bem fundadas esperanças de que o prejuizo possivel do Banco no meio de todas as calamidades que por modo tão assustador assaltárão a nossa Praça, será pouco considerável 
comparada com o débito das diversas firmas fallidas; pelo que não podemos deixar de render graças á Divina Providencia. (p. 18).

Apelou-se para a "Divina Providência" em virtude do aumento descomunal da carteira de títulos em liquidação.

Tabela 10 - Efeitos da contabilização do fundo de reserva no patrimônio na rentabilidade e distribuição de dividendos para os anos bancais de 1860 (em réis-mil)

\begin{tabular}{|c|c|c|c|c|c|c|c|c|c|c|c|}
\hline & 1860 & 1861 & 1862 & 1863 & 1864 & 1865 & 1866 & 1867 & 1868 & 1869 & Anos 1860 \\
\hline Lucro líquido divulgado & 3.037 .445 & 2.919 .444 & 2.572 .730 & 3.307 .372 & 3.194 .918 & 4.806 .443 & 6.014 .768 & 6.476 .288 & 5.642 .834 & 4.813 .871 & 42.670 .650 \\
\hline $\begin{array}{l}\text { (-) Costituição de fundo } \\
\text { de reserva }\end{array}$ & 182.247 & 173.344 & 154.247 & 197.991 & 186.508 & 965.644 & 2.136 .700 & 2.315 .783 & 2.382 .434 & 1.725 .071 & 10.419 .969 \\
\hline $\begin{array}{l}(=) \text { Lucro líquido } \\
\text { ajustado }\end{array}$ & 2.855 .199 & 2.746 .100 & 2.418 .483 & 3.109 .381 & 3.008 .410 & 3.840 .800 & 3.878 .068 & 4.160 .504 & 3.260 .400 & 3.088 .800 & 32.250 .681 \\
\hline \multicolumn{12}{|l|}{ Efeitos em \% } \\
\hline $\begin{array}{l}\text { Relativos aos lucros e } \\
\text { distribuição de } \\
\text { dividendos }\end{array}$ & $-6,00 \%$ & $-5,94 \%$ & $-6,00 \%$ & $-5,99 \%$ & $-5,84 \%$ & $-20,09 \%$ & $-35,52 \%$ & $-35,76 \%$ & $-42,22 \%$ & $-35,84 \%$ & $-24,42 \%$ \\
\hline Relativo ao ROE & $-0,47$ p.p. & $-0,45 p \cdot p$ & $-0,41 p . p$ & $-0,46 p . p$ & $-0,43 p . p$ & $-2,08$ p.p. & $-4,64$ p.p. & $-4,88$ p.p. & $-5,24$ p.p. & $-3,82$ p.p. & $\mathrm{n} / \mathrm{a}$ \\
\hline \multicolumn{12}{|l|}{ Efeitos absolutos } \\
\hline Dividendos divulgados & 2.679 .000 & 2.608 .500 & 2.289 .840 & 2.937 .000 & 2.887 .500 & 3.630 .000 & 3.630 .000 & 3.960 .000 & 3.135 .000 & 2.970 .000 & 30.726 .840 \\
\hline Dividendos ajustados & 2.518 .260 & 2.453 .619 & 2.152 .553 & 2.761 .181 & 2.718 .938 & 2.900 .711 & 2.340 .470 & 2.543 .988 & 1.811 .387 & 1.905 .688 & 23.223.492 \\
\hline ROE divulgado & $9,40 \%$ & $9,07 \%$ & $7,95 \%$ & $9,18 \%$ & $8,85 \%$ & $12,70 \%$ & $15,98 \%$ & $16,94 \%$ & $14,49 \%$ & $12,36 \%$ & $\mathrm{n} / \mathrm{a}$ \\
\hline ROE ajustado & $8,93 \%$ & $8,62 \%$ & $7,54 \%$ & $8,72 \%$ & $8,42 \%$ & $10,62 \%$ & $11,33 \%$ & $12,06 \%$ & $9,25 \%$ & $8,54 \%$ & $\mathrm{n} / \mathrm{a}$ \\
\hline
\end{tabular}

Verificamos que com a entrada dos anos de 1860 e por consequência de sua crise econômica, que a entidade faz um reforço importante no fundo de reserva sobretudo após 1866, que faz com que os efeitos sobre os lucros e dividendos sejam de ordem importante, diminuindo entre $35,52 \%$ a $42,22 \%$ menores com a contabilização como despesa.

A rentabilidade do patrimônio também é afetada de maneira extensa com valores menores nos primeiros anos de 1860 passando a valores altos após a segunda década, superando a faixa dos 4 p.p. em boa parte dos anos bancais.

As menções nos relatórios desses anos às perdas são diversas, bem como as esperanças da instituição. 
Lembremos nos últimos relatórios dos anos 50 que o banco apelava à divina providência. E já em 1860, a Divina Providência agiu, mesmo em período de redução das operações do Banco e em crise, o que seria de se supor seria um incremento em “Títulos em Liquidação", mas a Divina Providência não falhou (BB, 1860):

De 1 de Julho de 1859 a 30 de Junho do corrente anno, tem o Banco recebido em pagamentos por conta de titulos em liquidação, Rs. 252:707\$480.

Passaram a essa conta durante o anno bancario alguns titulos duvidosos na importancia de Rs. 39:387\$781.

Tendo passado para o fundo de reserva conforme a deliberação da Directoria, de que se vos deu conta no Relatorio do anno passado, R2. 109:979\$120; sendo no primeiro semestre Rs. 57:979\$120, e no segundo R2. 52:000\$000.

Cumpre acrescentar, que da importancia lançada á conta titulos em liquidação ainda tem o Banco uma grande parte a receber, vindo portanto a ser verdadeiramente insignificante o prejuiso real, mórmente attendendo-se á massa das transacções e á reducção que soffrera a carteira do Banco. (p. 14).

E por esse último parágrafo dá a entender que a rubrica Títulos em Liquidação tem mais saldos a receber do que a vencer, o que o futuro mostrou ser um engano.

$\mathrm{E}$ as menções às possíveis perdas na carteira, mesmo em ambiente pré-crise chegam a ser bem simplórias, como no caso de 1863 (BB, 1863):

A verba que figurava sob este titulo teve uma diminuição de 120:734\$896 em relação ao anno anterior. (p. 14).

No próprio ano cabal da crise (1864), o discurso em relação às perdas continuava bem tímido (BB, 1864):

A verba que figurava sob este titulo, teve uma alteração de 86:679\$308 em relação ao anno anterior. (p. 12).

Já em 1865, após o estopim, as divulgações e as contabilizações começam a ser mais entusiasmadas (BB, 1865): 
A verba que figurava sob este titulo teve um augmento de 4.814:349\$175 em relação ao anno anterior (...) (i.e. saiu de 753637\$020 para 5.567:986\$193)

Pelos dados que ficão expostos reconhece-se quaes forao em relação aos interesses do Banco os effeitos da crise de 1864.

Pela suspensão de pagamentos, e consequente fallencias de algumas importantes casas bancarias, intermediarias de avultadas transacções com o Banco, deixárão de ser pagos em seus respectivos vencimentos, titulos em grande numero que fazião parte da Carteira do Banco, e que todos forão immediatamente levados á conta de titulos em liquidação.

$\mathrm{Na}$ somma que representão esses titulos, incluem-se todos os que não são pontualmente solvidos no dia do vencimento, até que na liquidação final delles se reconheça o prejuiso que venha a resultar na cobrança de diversos coobrigados, ou sejão esses titulos objecto de nova convenção e accordo.

Assim é que a somma de 13.834:530\$900 que representa a importancia total desses titulos nos dous semestres do anno bancario, figura em 30 de Junho na quantia de 5.567:986\$195, sendo que o restante, deduzido os valores cobrados, e os prejuisos liquidados, apparecem com a denominação de letras de concordatas. Nas circumstancias em que se tem achado o nosso commercio, e no empenho de não contribuir para aggravar os fataes effeitos da crise, e reflectindo seriamente sobre esse ponto, entendeu a directoria que consultava melhor os interesses do estabelecimento, entrando em novos ajustes e convenções com os seus devedores, do que recorrendo aos meios judiciaes, no que aliás, pareceu-lhe que procedia de accordo com as vistas dos decretos expedidos pelo governo imperial em 17 e 20 de Setembro do anno passado.

Sendo a maior parte dos titulos em liquidação provenientes das fallencias das casas bancarias, julgo conveniente dar-vos conta da responsabilidade que tinhão para com o Banco essas casas na épocha em que suspendèrão os seus pagamentos, e do ultimo estado dessa responsabilidade, depois da liquidação que tem feito as respectivas comissões (p. 14). 
Tabela 11 - Efeitos da contabilização do fundo de reserva no patrimônio na rentabilidade e distribuição de dividendos para os anos bancais de 1870 (em réis-mil)

\begin{tabular}{|c|c|c|c|c|c|c|c|c|c|c|c|}
\hline & 1870 & 1871 & 1872 & 1873 & 1874 & 1875 & 1876 & 1877 & 1878 & 1879 & Anos 1870 \\
\hline $\begin{array}{l}\text { Lucro líquido } \\
\text { divulgado }\end{array}$ & 5.331 .642 & 4.988 .325 & 4.439 .432 & 4.697 .572 & 4.615 .113 & 4.475 .030 & 4.363 .247 & 5.294 .977 & 4.841 .969 & 4.337 .244 & 47.384 .551 \\
\hline $\begin{array}{l}\text { (-) Costituição de } \\
\text { fundo de reserva }\end{array}$ & 2.242 .842 & 2.272 .425 & 1.733 .432 & 1.991 .573 & 1.909 .113 & 1.598 .906 & 1.483 .604 & 2.244 .883 & 1.790 .751 & 1.289 .122 & 18.556 .651 \\
\hline $\begin{array}{l}\text { (=) Lucro líquido } \\
\text { ajustado }\end{array}$ & 3.088 .800 & 2.715 .900 & 2.706 .000 & 2.705 .999 & 2.706 .000 & 2.876 .125 & 2.879 .643 & 3.050 .094 & 3.051 .218 & 3.048 .122 & 28.827 .900 \\
\hline \multicolumn{12}{|l|}{ Efeitos em \% } \\
\hline $\begin{array}{l}\text { Relativos aos lucros e } \\
\text { distribuição de } \\
\text { dividendos }\end{array}$ & $-42,07 \%$ & $-45,55 \%$ & $-39,05 \%$ & $-42,40 \%$ & $-41,37 \%$ & $-35,73 \%$ & $-34,00 \%$ & $-42,40 \%$ & $-36,98 \%$ & $-29,72 \%$ & $-39,16 \%$ \\
\hline Relativo ao ROE & $-5,02$ p.p. & $-4,76$ p.p. & $-3,78 p . p$ & $-4,58$ p.p. & $-4,44 p . p$ & $-3,67$ p.p. & $-3,31$ p.p. & $-4,71$ p.p. & $-3,72$ p.p. & $-2,62 p . p$. & $\mathrm{n} / \mathrm{a}$. \\
\hline \multicolumn{12}{|l|}{ Efeitos absolutos } \\
\hline $\begin{array}{l}\text { Dividendos } \\
\text { divulgados }\end{array}$ & 2.970 .000 & 2.640 .000 & 2.640 .000 & 2.640 .000 & 2.640 .000 & 2.805 .000 & 2.805 .000 & 2.970 .000 & 2.970 .000 & 2.970 .000 & 28.050 .000 \\
\hline Dividendos ajustados & 1.720 .621 & 1.437 .351 & 1.609 .179 & 1.520 .751 & 1.547 .923 & 1.802 .788 & 1.851 .235 & 1.710 .825 & 1.871 .577 & 2.087 .252 & 17.065 .110 \\
\hline ROE divulgado & $13,83 \%$ & $11,69 \%$ & $10,92 \%$ & $12,28 \%$ & $12,22 \%$ & $11,86 \%$ & $11,19 \%$ & $12,69 \%$ & $11,50 \%$ & $10,08 \%$ & $\mathrm{n} / \mathrm{a}$ \\
\hline ROE ajustado & $8,81 \%$ & $6,93 \%$ & $7,14 \%$ & $7,70 \%$ & $7,78 \%$ & $8,19 \%$ & $7,88 \%$ & $7,98 \%$ & $7,78 \%$ & $7,46 \%$ & $\mathrm{n} / \mathrm{a}$ \\
\hline
\end{tabular}

Nos anos de 1870 os efeitos da crise da década passada são minorados aos poucos, porém a contabilização dos fundos de reserva ainda se mantém em níveis razoáveis, contudo não como outrora.

Mesmo assim, os lucros e dividendos distribuídos seriam menores na faixa de 29,72\% a $42,40 \%$ se os fundos de reserva contabilizados como despesa fossem na época. A rentabilidade sobre o patrimônio também varia em ordens altas superior a 4p.p. nos anos de 1870.

Interessante notar que os dividendos totais distribuídos correspondem a praticamente à totalidade do lucro líquido ajustado no período. E nesse período de florescimento da produção cafeeira, em 10 anos quase o patrimônio inteiro fora devolvido aos sócios.

Os relatórios dos anos de 1870 já mostram um discurso menos aberto $(\mathrm{BB}, 1870)$ :

Forão descriminados os titulos em liquidação da Carteira hypothecaria, e escripturados nesta verba e na correspondente da Carteira commercial todos os titulos vencidos e ainda não pagos, tudo de conformidade com a resolução tomada pela assembléa geral dos Srs. accionistas no anno passado. A consequencia desta deliberação foi a elevação de taes verbas á quantia de 16.557:118\$432. (p. 11). 
A visão das perdas é contrastada com a "sólida" situação da instituição (BB, 1870):

A' vista deste resultado, se fundos de reserva, principalmente o novo e o especial, forem augmentando annualmente na mesms progressão, é claro que em poucos annos o capital do Banco ficará garantido, ainda mesmo que mais alguns tittulos temhão de ser levados á conta de liquidação, como é certo.

Procurar com esforço destruir a grande quantidade de titulos em liquidação pela sua activa cobrança, descontar sômente aqulles que sejão pagos no dia de seus vencimentos, tal tem sido a marcha da Administração em geral, e se ella fôr continuada com vigor discernimento, os resultados não serão duvidosos. (p. 13)

Mesmo créditos já antigos, como os devidos pela Casa Mauá ainda figuravam nas demonstrações, mesmo após mais de década nos esforços ao recebimento da falência (BB, 1878):

Outro tanto não pôde conseguir a casa Mauá \&C, sendo obrigada a requerer a abertura de sua fallencia.

O processo da fallencia tem caminhado toda a celeridade possível. Encarando a posição do Banco como credor da casa Mauá \& C., devo informar-vos, que nosso credio é hoje de 5,852:156\$130, que se acha em grande parte garantido por hypothecas de prédios nesta côrte, bens ruraes, e pelo estabelecimento denominado ---Ponta da Arêa---, cujas excurssões devem produzir somma elevada, ficando ao Banco o direito de receber como credor chirographario sobre o saldo que accusar a conta os rateios que a massa produzir. (p.11). 
Tabela 12 - Efeitos da contabilização do fundo de reserva no patrimônio na rentabilidade e distribuição de dividendos para os anos bancais de 1880 (em réis-mil)

\begin{tabular}{|c|c|c|c|c|c|c|c|c|c|c|c|}
\hline & 1880 & 1881 & 1882 & 1883 & 1884 & 1885 & 1886 & 1887 & 1888 & 1889 & Anos 1880 \\
\hline $\begin{array}{l}\text { (-) Costituição de } \\
\text { fundo de reserva }\end{array}$ & 1.551 .486 & 1.208 .158 & 1.268 .566 & 1.331 .994 & 1.737 .336 & 1.020 .077 & 979.527 & 1.281 .308 & 845.015 & 860.568 & 12.084 .034 \\
\hline $\begin{array}{l}\text { (=) Lucro líquido } \\
\text { ajustado }\end{array}$ & 3.386 .336 & 3.382 .500 & 3.551 .625 & 3.729 .206 & 3.382 .500 & 2.875 .125 & 2.875 .125 & 3.044 .250 & 2.444 .250 & 2.691 .040 & 31.361 .957 \\
\hline \multicolumn{12}{|l|}{ Efeitos em \% } \\
\hline $\begin{array}{l}\text { Relativos aos } \\
\text { lucros e } \\
\text { distribuição de } \\
\text { dividendos }\end{array}$ & $-31,42 \%$ & $-26,32 \%$ & $-26,32 \%$ & $-26,32 \%$ & $-33,93 \%$ & $-26,19 \%$ & $-25,41 \%$ & $-29,62 \%$ & $-25,69 \%$ & $-24,23 \%$ & $-27,81 \%$ \\
\hline $\begin{array}{l}\text { Dividendos } \\
\text { divulgados }\end{array}$ & 3.300 .000 & 3.300 .000 & 3.300 .000 & 3.300 .000 & 3.300 .000 & 2.805 .000 & 2.805 .000 & 2.970 .000 & 2.370 .000 & 2.640 .000 & 30.090 .000 \\
\hline $\begin{array}{l}\text { Dividendos } \\
\text { ajustados }\end{array}$ & 2.263 .125 & 2.431 .514 & 2.431 .514 & 2.431 .514 & 2.180 .197 & 2.070 .426 & 2.092 .206 & 2.090 .233 & 1.761 .145 & 2.000 .318 & 21.752 .192 \\
\hline ROE divulgado & $11,37 \%$ & $10,55 \%$ & $11,08 \%$ & $11,64 \%$ & $11,65 \%$ & $9,23 \%$ & $9,43 \%$ & $10,37 \%$ & $7,81 \%$ & $8,78 \%$ & $\mathrm{n} / \mathrm{a}$ \\
\hline ROE ajustado & $8,30 \%$ & $8,17 \%$ & $8,59 \%$ & $9,03 \%$ & $8,23 \%$ & $7,11 \%$ & $7,34 \%$ & $7,70 \%$ & $6,01 \%$ & $6,91 \%$ & $\mathrm{n} / \mathrm{a}$ \\
\hline
\end{tabular}

Nos anos de 1880, nos meandros do ato da abolição, os resultados verificados permanecem similares àqueles dos decênios anteriores. Os lucros e dividendos da década seriam 27,81\% menores, alcançando a máxima de 33,93\% negativos em 1884 .

A rentabilidade do patrimônio também seria decrescida em faixas negativas altas, superiores a 2 p.p. na maior parte dos anos bancais, com mínima de -1.80p.p e e máxima de $-3,42$ p.p.

A administração elucida novamente de maneira otimista o cenário e o direcionamento dos títulos em liquidação (BB, 1881):

Convem observar que a maior parte das sommas levadas a credito da conta dos titulos em liquidação representa dividas de antigas massas fallidas, que vão desapparecendo do activo quando a administração do Banco entende que nada mais ha a receber dos respectivos devedores. (p. 6).

Em 1884, a entidade divulga uma listagem analítica da composição dos seus devedores e as expectativas da instituição (BB, 1884): 
13.785.631\$240, que devem 349 mutuarios, acham-se com as prestações pagas em dia.

3.197.707\$050, que devem 84 mutuarios, estão estes em atrazo de uma prestação.

3.310.164\$790, que devem 59 mutuarios, estão estes em atrazo de duas prestações.

1.034.437\$000, que devem 29 mutuarios, estão estes em atrazo de tres prestações.

793.241\$820, que devem 30 mutuarios, estão estes em atrazo de quatro prestações.

3.047.902\$550, que devem 80 mutuarios, estão estes em atrazo de 5 ou mais prestações.

Para se conhecer o estado dos bens dos devedores em atrazo, foram os peritos do Banco encarregados de visitar as propriedades hypothecadas e syndicar quaes as causas determinativas do atrazo d'esses devedores; os peritos já apresentaram relatorios de mais de trinta fazendas, sendo na generalidade lisongeiras as informações prestadas sobre as mesmas.

Foi uma medida salutar e que a gerencia continuará a pôr em execução, porque o conhecimento exacto do estado de prosperidade ou decadencia de uma fazenda, determinará o procedimento a tomar-se para com os devedores remissos.

Como V. Ex. sabe, de um trabalho estatistico que a gerencia fez organisar, ficou averiguado que as terras e benfeitorias hypothecadas ao Banco, abstracção feita dos escravos, e consideradas as avaliações em globo, valem quasi o dobro dos saldos do capital ora devido, e, ainda considerando-se contracto por contracto, como deve ser, valem quasi sempre $50 \%$ ou mais do debito de cada mutuario. (p. 16)

Relevante observarmos que aproximadamente metade da carteira encontrava-se em problemas de atraso e o mesmo assim havia a esperança ou a generosidade em relação aos mesmos.

Já no próximo exercício bancal, a expectativa já não era tão lisonjeira $(\mathrm{BB}, 1885)$ :

Não correrão bem os negocios durante este periodo: a estagnação de avultado capital da carteira commercial, que se acha sob protestos, fallencias e moratorias, e a liquidação de prejuizos realisados, agorentando os lucros e absorvendo uma boa parte dos fundos de reserva (como adiante vereis) determinarão a deliberação que o conselho director tomou de diminuir os dividendos afim de ir fortalecendo as reservas destinadas a compensar as perdas, que por ventura se tenhão ainda de verificar nas contas do activo. E podeis acreditar, Srs. accionistas, que a administração guiando-se pelo que o interesse do Banco a 
aconselha, envida todos os esforços para conseguir minorar aquellas perdas, já que não é possível evital-as de todo.

Façamos votos por melhores tempos. (p. 6).

A menção aqui se torna interessante, já que o lucro não fora afetado pelas perdas na carteira, devido à tratativa adotada quanto à contabilização das mesmas. Porém, o incremento lançado ao fundo de reserva, fez com que a entidade propusesse a diminuição do dividendo, novamente, não apurado conforme o lucro, mas como uma remuneração quase fixa ao capital empregado.

Tabela 13 - Efeitos da contabilização do fundo de reserva no patrimônio na rentabilidade e distribuição de dividendos para os anos bancais de 1890 a 1900 (em réis-mil)

\begin{tabular}{|c|c|c|c|c|c|c|c|c|c|c|c|c|}
\hline & 1890 & 1891 & 1892 & 1893 & 1.894 & 1.895 & 1.896 & 1.897 & 1.898 & 1.899 & 1900 & $\begin{array}{r}\text { De } 1890 \text { a } \\
1900\end{array}$ \\
\hline $\begin{array}{l}\text { Lucro líquido } \\
\text { divulgado } \\
\end{array}$ & 6.016 .132 & 12.970 .968 & 15.964 .741 & 4.784 .340 & 12.729 .340 & 11.938 .397 & 10.601 .908 & 11.295 .489 & 9.945 .966 & 9.274 .459 & 9.009 .208 & 114.530 .950 \\
\hline $\begin{array}{l}\text { (-) Costituição de } \\
\text { fundo de reserva }\end{array}$ & 1.510 .547 & 2.328 .676 & 4.000 .000 & 1.909 .401 & 1.909 .401 & 1.790 .760 & 1.590 .286 & 1.694 .323 & 1.491 .895 & 1.396 .169 & 1.351 .381 & 20.972 .839 \\
\hline $\begin{array}{l}(=) \text { Lucro líquido } \\
\text { ajustado }\end{array}$ & 4.505 .585 & 10.642 .293 & 11.964 .741 & 2.874 .939 & 10.819 .939 & 10.147 .638 & 9.011 .622 & 9.601 .166 & 8.454 .071 & 7.878 .290 & 7.657 .827 & 93.558 .111 \\
\hline \multicolumn{13}{|l|}{ Efeitos em \% } \\
\hline $\begin{array}{l}\text { Relativos aos } \\
\text { lucros e } \\
\text { distribuição de } \\
\text { dividendos }\end{array}$ & $-25,11 \%$ & $-17,95 \%$ & $-25,06 \%$ & $-39,91 \%$ & $-15,00 \%$ & $-15,00 \%$ & $-15,00 \%$ & $-15,00 \%$ & $-15,00 \%$ & $-15,05 \%$ & $-15,00 \%$ & $-18,31 \%$ \\
\hline Relativo ao ROE & $-1,19$ p.p. & $-1,41$ p.p. & $-2,35$ p.p. & $-0,78$ p.p. & $-0,74$ p.p. & $-0,74 p . p$ & $-0,69$ p.p. & $-1,00$ p.p. & $-1,01$ p.p. & $-0,96 p . p$. & $-0,93 p . p$ & $\mathrm{n} / \mathrm{a}$ \\
\hline \multicolumn{13}{|l|}{$\begin{array}{c}\text { Efeitos } \\
\text { absolutos }\end{array}$} \\
\hline $\begin{array}{l}\text { Dividendos } \\
\text { divulgados }\end{array}$ & 4.439 .000 & 10.485 .018 & 10.640 .000 & 7.952 .952 & 7.952 .952 & 7.715 .712 & 7.469 .634 & 7.365 .354 & 7.112 .580 & 6.461 .952 & 6.155 .160 & 83.750 .314 \\
\hline $\begin{array}{l}\text { Dividendos } \\
\text { ajustados }\end{array}$ & 3.324 .443 & 8.602 .644 & 7.974 .125 & 4.778 .977 & 6.760 .009 & 6.558 .355 & 6.349 .189 & 6.260 .551 & 6.045 .693 & 5.489 .175 & 5.231 .886 & 68.414 .006 \\
\hline ROE divulgado & $5,10 \%$ & $9,11 \%$ & $10,94 \%$ & $2,03 \%$ & $5,36 \%$ & $5,34 \%$ & $4,97 \%$ & $7,47 \%$ & $7,58 \%$ & $7,12 \%$ & $6,88 \%$ & $\mathrm{n} / \mathrm{a}$ \\
\hline ROE ajustado & $3,90 \%$ & $7,70 \%$ & $8,59 \%$ & $1,24 \%$ & $4,62 \%$ & $4,60 \%$ & $4,28 \%$ & $6,47 \%$ & $6,57 \%$ & $6,16 \%$ & $5,95 \%$ & $\mathrm{n} / \mathrm{a}$ \\
\hline
\end{tabular}

No anos compreendidos entre 1890 e 1900 e primeiros da República há uma diminuição dos efeitos da contabilização dos devedores duvidosos no resultado ajustado, porém ainda situados em faixas altas superiores a $15 \%$ negativos, mas com um máximo de 39,91\% em 1893. Aparentemente uma política do banco de contabilizar $15 \%$ do lucro com fundo de reserva, porém não explícita nos documentos a que tivemos acesso.

Nessa mesma direção o ROE passa a também oscilar em extremos menores, inferiores a 1 p.p. negativos em boa parte dos exercícios bancais. 
O discurso nos anos 90 já voltam àquele tom menos analítico como verificado nos relatórios dos anos de 1850 e primeiros meados dos anos 60. Vejamos um extrato (BB, 1896):

(...) cumpre reconhecer que os atrazos nos pagamentos das prestações de juros e amortisações vencidas são menores do que seria para receiar. (p. 15). 


\section{3 - A NEFASTA DISTRIBUIÇÃO DO PÚBLICO PARA O PRIVADO}

Mas, talvez, o produto mais nefasto e principal justificativa da dinâmica exploratória burguesa (o lucro, o dinheiro) está na distribuição de dividendos para a classe dominante e para o Estado, já que como sabemos lucro não significa entrada de caixa e como verificamos quase por completude o lucro é distribuído aos capitalistas.

Agora verificaremos os efeitos das duas práticas acima e sua consequencia no tocante à distribuição dos dividendos aos capitalistas brasileiros da época. Elucidaremos o caráter exploratório que o Banco empregou durante todo o período, desfalcando a instituição e o país como um todo, contribuindo, inclusive para o problema de liquidez da mesma, que recorria, como vimos, frequentemente a favores do poder público para a emissão de notas.

A análise se dará novamente por decênios. A tabela abaixo mostra os anos de 1850:

Tabela 14 - A distribuição de dividendos comparando os números reais e ajustados nos anos de 1850 (em réis-mil)

\begin{tabular}{|c|c|c|c|c|c|c|c|}
\hline & 1854 & 1855 & 1856 & 1857 & 1858 & 1859 & Anos 1850 \\
\hline Lucro líquido divulgado & 1.332 .833 & 1.870 .136 & 2.552 .061 & 2.552 .461 & 4.436 .241 & 3.037 .965 & 15.781 .698 \\
\hline (-) Costituição de fundo de reserva & 79.647 & 111.097 & 153.124 & 153.122 & 265.208 & 182.247 & 944.444 \\
\hline (-) Remuneração dos diretores & 49.912 & 69.621 & 113.585 & 113.585 & 177.450 & 121.519 & 645.671 \\
\hline (=) Lucro líquido ajustado & 1.203 .275 & 1.689 .418 & 2.285 .352 & 2.285 .754 & 3.993 .583 & 2.734 .200 & 14.191 .583 \\
\hline \multicolumn{8}{|l|}{ Efeitos em \% } \\
\hline Relativos aos lucros e distribuição de dividendos & $-9,72 \%$ & $-9,66 \%$ & $-10,45 \%$ & $-10,45 \%$ & $-9,98 \%$ & $-10,00 \%$ & $-10,08 \%$ \\
\hline Relativo ao ROE & $-0,40$ p.p. & $-0,52 \mathrm{p} . \mathrm{p}$. & $-0,72 p . p$. & $-0,72$ p.p. & $-1,03$ p.p. & $-0,79$ p.p. & $\mathrm{n} / \mathrm{a}$ \\
\hline \multicolumn{8}{|l|}{ Efeitos absolutos } \\
\hline Dividendos divulgados & 1.202 .300 & 1.688 .000 & 2.282 .400 & 2.282 .400 & 3.962 .100 & 2.679 .000 & 14.096.200 \\
\hline Dividendos ajustados & 1.085 .430 & 1.524 .882 & 2.043 .873 & 2.043 .912 & 3.566 .753 & 2.411 .128 & 12.675 .978 \\
\hline Descapitalização do banco em réis & -116.870 & -163.118 & -238.527 & -238.488 & -395.347 & -267.872 & -1.420 .222 \\
\hline Dividendo/lucro divulgado & $90,21 \%$ & $90,26 \%$ & $89,43 \%$ & $89,42 \%$ & $89,31 \%$ & $88,18 \%$ & $89,32 \%$ \\
\hline Dividendo ajustado/lucro divulgado & $81,44 \%$ & $81,54 \%$ & $80,09 \%$ & $80,08 \%$ & $80,40 \%$ & $79,37 \%$ & $80,32 \%$ \\
\hline Dividendo real/lucro ajustado & $99,92 \%$ & $99,92 \%$ & $99,87 \%$ & $99,85 \%$ & $99,21 \%$ & $97,98 \%$ & $99,33 \%$ \\
\hline
\end{tabular}


Notemos que já nos seus primeiros relatórios, o banco já era acusado de ser instrumento exclusivo de remuneração de seus acionistas.

Nesses primeiros seis anos de existencia, o banco já se vira desfalcado de praticamente $50 \%$ de seu capital realizado (14.096.200\$000 de 33.000.000\$000), além de ter distribuído praticamente todo o seu lucro aos acionistas a cada exercício social, fazendo com que o banco sofresse com liquidez, já que como sabemos lucro não significa necessariamente caixa, recorrendo comumente aos poderes de estado para regularizar tal problema de encaixe.

Notamos que a instituição distribuiu 89,32\% (!!!) do lucro gerado aos capitalistas, promovendo uma descapitalização total superior a 14 mil contos.

Agora vejamos como eles declaram os pagamentos aos acionistas. A maneira curiosa com que esses dividendos são descritos, já que a conta não é feita sobre o lucro, mas sim sobre o capital realizado. Vejamos o exemplo do ano bancal de 1857 (BB, 1857):

O dividendo do 1.0 semestre está na razão de 3,85 por cento do capital realisado e o do 2 .o de 6,82 por cento, ou termo medio do anno 10,67 por cento. (p. 10)

Dá a impressão de que a taxa de distribuição é de apenas $10 \%$.

Caso utilizemos os números ajustados, aplicando-se a mesma taxa absurda de distribuição sobre o lucro, o desfalque na instituição seria 1.420.222\$101 menor que o real. A sua rentabilidade e a distribuição de dividendos com os números ajustados seriam diminuídos em média $10 \%$ nesse período e a rentabilidade do patrimônio decrescente entre -.4p.p. e -1,03 p.p.

Abaixo, vejamos o caso dos anos de 1860: 
Tabela 15 - A distribuição de dividendos comparando os números reais e ajustados nos anos de 1860 (em réis-mil)

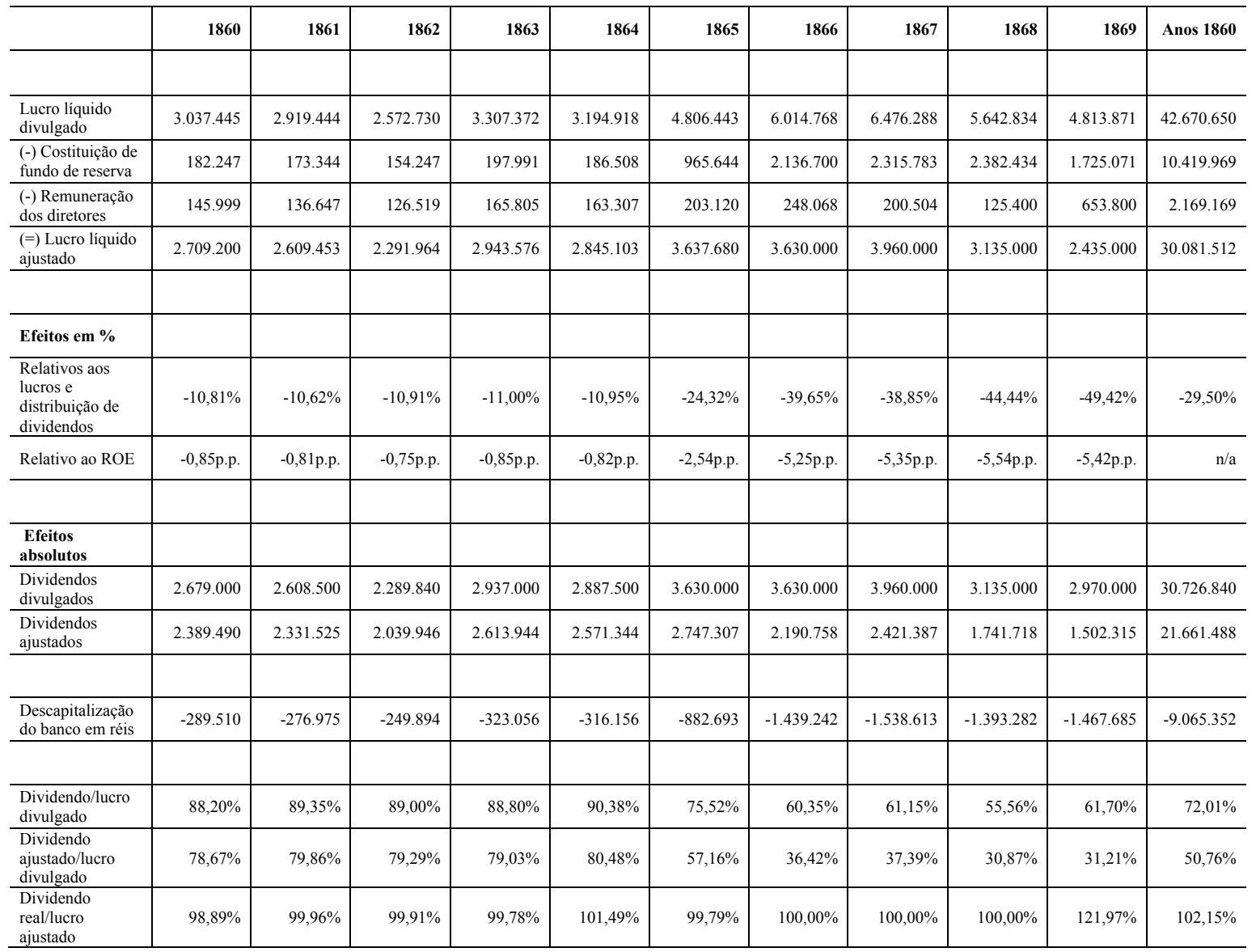

Nessa década, como vimos mais acima houve o incremento do fundo de reserva para compensar os prejuizos da carteira decorrente da crise de meados dos anos 60. Assim sendo, verificamos que mesmo nesse cenário, a distribuição de recursos para os acionistas continua em alta.

Considerando os números reais, talvez possamos pensar que há uma diminuição no pagamento aos sócios, oscilando em faixas menores que $60 \%$ sobretudo após a primeira metade da década; porém o que ocorre é justamente o contrário, já que após as destinações para o fundo de reserva e a parcela dos diretores, verificamos que ou todo o lucro fora pago aos acionistas, inclusive com alguns anos bancais, como 1864 e 1869, valores superiores ao lucro ajustado.

A descapitalização total atinge nesse decênio a marca de quase $100 \%$ do capital realizado, sendo distribuido mais que a totalidade do lucro líquido ajustado no período para os acionistas. 
Se os dividendos distribuídos fossem calculados com base no lucro ajustado, o desfalque nos cofres do banco e a remuneração aos sócios seria de quase 9 mil contos a menor para os dois envolvidos. Além disso, a rentabilidade e distribuição de dividendos seriam bem menores, em especial após a segunda metade, atingindo máxima de 49,42\% a menor em 1869 com os números ajustados.

Nesse cenário, o banco sofreu desencaixe de maneira relevante no período, novamente recorrendo aos poderes políticos para honrar seus problemas de liquidez. Assim, além do ônus de financiamento da guerra do Paraguai, o banco também foi instrumento de remuneração aos acionistas.

Mas nos relatórios a menção aos dividendos continuam bem menos entusiasmados e praticamente uma cópia dos textos da década passada (BB, 1861, 1863):

O dividendo do 1.0 semestre regulou a $6,25 \%$ e o do 2.0 semestre a $5,31 \%$, e calculado por anno sobre o capital realisado, produzio $11,56 \%$. $(1861$, p. 11$)$

(...)

O dividendo do primeiro semestre foi de $7 \$ 800$ por acção ou $4,875 \%$ do capital realisado e o segundo $10 \$ 000$ na razão de $6,250 \%$; e sendo reunidos os dous dividendos dão $17 \$ 800$ por acção ou $11,125 \%$ ao anno. (1863, p. 13)

Mas os acionistas não estavam satisfeitos (BB, 1864):

O facto de haver o Banco do Brasil distribuido aos seus accionistas, nos ultimos dous semestres, dividendos comparativamente diminutos, em relação aos de annos anteriores, ao passo que fôra o seu capital social completado com o producto das duas ultimas chamadas na subida importancia de 6,600 contos, parece ter impressionado desfavoravelmente alguns espiritos menos reflectidos, os quaes, comparando instictivamente os referidos dividendos com os que repartira outro Banco de simples desconto, que funcciona nesta praça com um capital inferior á quarta parte do que actualmente dispõe o Banco do Brasil, não hesitão em tirar d'ahi argumento, no seu entender concludentes, contra as vantagens reaes que possam auferir aquelles que tem ligado os seus interesses á existencia e futuro dessa primeira instituição de credito do nosso paiz. (grifo nosso) 
Entre outras causas de influencia secundaria, cumpre aqui assignalar tres factos que mais directamente concorrerão para amesquinhar o valor numerico das quotas que representão os dividendos em questão, a saber:

1.o A recente fundação de mais dous Bancos de desconto, os quaes funcionando nesta praça em livre concorrencia com todos os outros estabelecimentos bancarios, tem desviado destes uma consideravel massa de negocios.

(...) A presente situação do Banco do Brasil, com respeito ao facto de que venho a fallar, não somente terá de experimentar sensível melhoramento, mediante a maior actividade commercial, estimulada por um progressivo augmento em nossa producção; mas até poderão desde já os seus accionistas contemplar nas suas previsões a certeza de verem augmentada permanentemente, em um futuro mui proximo, a massa dos dividendos anuaes, com a importante addição da parte da renda liquida do Banco, que é destinada á formação do seu fundo de reserva, o qual, representando já metade do seu valor integral de 3,300 contos se completará talvez em menos de 4 annos. (p. 11)

Como verificamos não houve redução nos dividendos, muito pelo contrário, os mesmos permaneceram em níveis extremamente altos quando colocados em perspectiva comparativa com os lucros gerados.

E no ano seguinte, a insatisfação é amenizada, com a remuneração e a divulgação dos mesmos voltando aos níveis antigos (BB, 1865):

Os dividendos distrbuidos aos accionistas durante o anno estão na razão de $11 \%$ do valor nominal das acções. (p. 11).

Agora abordaremos os anos de 1870: 
Tabela 16 - A distribuição de dividendos comparando os números reais e ajustados nos anos de 1870 (em réis-mil)

\begin{tabular}{|c|c|c|c|c|c|c|c|c|c|c|c|}
\hline & 1870 & 1871 & 1872 & 1873 & 1874 & 1875 & 1876 & 1877 & 1878 & 1879 & Anos 1870 \\
\hline $\begin{array}{l}\text { Lucro líquido } \\
\text { divulgado }\end{array}$ & 5.331 .642 & 4.988 .325 & 4.439 .432 & 4.697 .572 & 4.615 .113 & 4.475 .030 & 4.363 .247 & 5.294 .977 & 4.841 .969 & 4.337 .244 & 47.384 .551 \\
\hline $\begin{array}{l}\text { (-) Costituição de } \\
\text { fundo de reserva }\end{array}$ & 2.242 .842 & 2.272 .425 & 1.733 .432 & 1.991 .573 & 1.909 .113 & 1.598 .906 & 1.483 .604 & 2.244 .883 & 1.790 .751 & 1.289 .122 & 18.556 .651 \\
\hline $\begin{array}{l}\text { (-) Remuneração } \\
\text { dos diretores }\end{array}$ & 118.800 & 75.900 & 66.000 & 66.000 & 66.000 & 71.125 & 74.643 & 80.094 & 81.218 & 78.122 & 777.901 \\
\hline $\begin{array}{l}\text { (=) Lucro líquido } \\
\text { ajustado }\end{array}$ & 2.970 .000 & 2.640 .000 & 2.640 .000 & 2.639 .999 & 2.640 .000 & 2.805 .000 & 2.805 .000 & 2.970 .000 & 2.970 .000 & 2.970 .000 & 28.049 .999 \\
\hline \multicolumn{12}{|l|}{ Efeitos em \% } \\
\hline $\begin{array}{l}\text { Relativos aos } \\
\text { lucros e } \\
\text { distribuição de } \\
\text { dividendos }\end{array}$ & $-44,29 \%$ & $-47,08 \%$ & $-40,53 \%$ & $-43,80 \%$ & $-42,80 \%$ & $-37,32 \%$ & $-35,71 \%$ & $-43,91 \%$ & $-38,66 \%$ & $-31,52 \%$ & $-40,80 \%$ \\
\hline Relativo ao ROE & $-5,31 \mathrm{p} . \mathrm{p}$ & $-4,93$ p.p. & $-3,93$ p.p. & $-4,75$ p.p. & $-4,60$ p.p. & $-3,85$ p.p. & $-3,49$ p.p. & $-4,89$ p.p. & $-3,90$ p.p. & $-2,79$ p.p. & $\mathrm{n} / \mathrm{a}$. \\
\hline \multicolumn{12}{|l|}{ Efeitos absolutos } \\
\hline $\begin{array}{l}\text { Dividendos } \\
\text { divulgados }\end{array}$ & 2.970 .000 & 2.640 .000 & 2.640 .000 & 2.640 .000 & 2.640 .000 & 2.805 .000 & 2.805 .000 & 2.970 .000 & 2.970 .000 & 2.970 .000 & 28.050 .000 \\
\hline $\begin{array}{l}\text { Dividendos } \\
\text { ajustados }\end{array}$ & 1.654 .443 & 1.397 .182 & 1.569 .931 & 1.483 .660 & 1.510 .169 & 1.758 .206 & 1.803 .250 & 1.665 .900 & 1.821 .759 & 2.033 .757 & 16.604 .620 \\
\hline $\begin{array}{l}\text { Descapitalização } \\
\text { do banco em réis }\end{array}$ & -1.315 .557 & -1.242 .818 & -1.070 .069 & -1.156 .340 & -1.129 .831 & -1.046 .794 & -1.001 .750 & -1.304 .100 & -1.148 .241 & -936.243 & -11.445 .380 \\
\hline $\begin{array}{l}\text { Dividendo/lucro } \\
\text { divulgado }\end{array}$ & $55,71 \%$ & $52,92 \%$ & $59,47 \%$ & $56,20 \%$ & $57,20 \%$ & $62,68 \%$ & $64,29 \%$ & $56,09 \%$ & $61,34 \%$ & $68,48 \%$ & $59,20 \%$ \\
\hline $\begin{array}{l}\text { Dividendo } \\
\text { ajustado/lucro } \\
\text { divulgado }\end{array}$ & $31,03 \%$ & $28,01 \%$ & $35,36 \%$ & $31,58 \%$ & $32,72 \%$ & $39,29 \%$ & $41,33 \%$ & $31,46 \%$ & $37,62 \%$ & $46,89 \%$ & $35,04 \%$ \\
\hline $\begin{array}{l}\text { Dividendo } \\
\text { real/lucro ajustado }\end{array}$ & $100,00 \%$ & $100,00 \%$ & $100,00 \%$ & $100,00 \%$ & $100,00 \%$ & $100,00 \%$ & $100,00 \%$ & $100,00 \%$ & $100,00 \%$ & $100,00 \%$ & $100,00 \%$ \\
\hline
\end{tabular}

Os anos de 1870 assistem a completa distribuição dos lucros do banco aos acionistas, como demostra o dividendo real em relação ao lucro ajustado (100\% em todos os períodos).

Caso o lucro considerado fosse o ajustado, o banco pagaria dividendos de aproximadamente $40 \%$ menores no decênio aos capitalistas, devido à diminuição da sua base de cálculo, o lucro, fato este que diminuiria seus rendimentos numa faixa anual de mil contos de réis, totalizando mais de 11 mil contos nos anos de 1870 .

Com os mesmos ajustes, a rentabilidade sobre o patrimônio seria reduzida na faixa de $-2,79$ p.p e 5,31 p.p.

Nos anos 70, a divulgação dos dividendos continuam naquele formato mais simples (BB, 1873, 1879): 
Os dividendos distribuídos durante o anno estão na razão de $8 \%$ do valor nominal das acções. (1873, p. 17).

\section{(...)}

Os dividendos distribuídos durante o anno estão na razão de $9 \%$ do valor nominal das acções. (p. 20).

No decênio dos anos de 1880, o efeito dos dividendos sobre a instituição continua o mesmo dos anos bancais anteriores.

Tabela 17 - A distribuição de dividendos comparando os números reais e ajustados nos anos de 1880 (em réis-mil)

\begin{tabular}{|c|c|c|c|c|c|c|c|c|c|c|c|}
\hline & 1880 & 1881 & 1882 & 1883 & 1884 & 1885 & 1886 & 1887 & 1888 & 1889 & Anos 1880 \\
\hline $\begin{array}{l}\text { Lucro líquido } \\
\text { divulgado }\end{array}$ & 4.937 .822 & 4.590 .658 & 4.820 .191 & 5.061 .200 & 5.119 .836 & 3.895 .202 & 3.854 .652 & 4.325 .558 & 3.289 .265 & 3.551 .608 & 43.445 .991 \\
\hline $\begin{array}{l}\text { (-) Costituição de } \\
\text { fundo de reserva }\end{array}$ & 1.551 .486 & 1.208 .158 & 1.268 .566 & 1.331 .994 & 1.737 .336 & 1.020 .077 & 979.527 & 1.281 .308 & 845.015 & 860.568 & 12.084 .034 \\
\hline $\begin{array}{l}\text { (-) Remuneração } \\
\text { dos diretores }\end{array}$ & 86.336 & 82.500 & 82.500 & 82.500 & 82.500 & 70.125 & 70.125 & 74.250 & 74.250 & 51.040 & 756.126 \\
\hline $\begin{array}{l}\text { (=) Lucro líquido } \\
\text { ajustado }\end{array}$ & 3.300 .000 & 3.300 .000 & 3.469 .125 & 3.646 .706 & 3.300 .000 & 2.805 .000 & 2.805 .000 & 2.970 .000 & 2.370 .000 & 2.640 .000 & 30.605 .831 \\
\hline \multicolumn{12}{|l|}{ Efeitos em \% } \\
\hline $\begin{array}{l}\text { Relativos aos } \\
\text { lucros e } \\
\text { distribuição de } \\
\text { dividendos }\end{array}$ & $-33,17 \%$ & $-28,11 \%$ & $-28,03 \%$ & $-27,95 \%$ & $-35,54 \%$ & $-27,99 \%$ & $-27,23 \%$ & $-31,34 \%$ & $-27,95 \%$ & $-25,67 \%$ & $-27,81 \%$ \\
\hline Relativo ao ROE & $-3,26 p . p$ & $-2,56 \mathrm{p} . \mathrm{p}$ & $-2,67$ p.p. & $-2,78$ p.p. & $-3,59$ p.p. & $-2,27 p . p$ & $-2,25 p . p$ & $-2,84$ p.p. & $-1,96 p . p$. & $-1,99$ p.p. & $\mathrm{n} / \mathrm{a}$ \\
\hline \multicolumn{12}{|l|}{$\begin{array}{c}\begin{array}{c}\text { Efeitos } \\
\text { absolutos }\end{array} \\
\end{array}$} \\
\hline $\begin{array}{l}\text { Dividendos } \\
\text { divulgados }\end{array}$ & 3.300 .000 & 3.300 .000 & 3.300 .000 & 3.300 .000 & 3.300 .000 & 2.805 .000 & 2.805 .000 & 2.970 .000 & 2.370 .000 & 2.640 .000 & 30.090 .000 \\
\hline $\begin{array}{l}\text { Dividendos } \\
\text { ajustados }\end{array}$ & 2.205 .426 & 2.372 .209 & 2.375 .033 & 2.377 .723 & 2.127 .021 & 2.019 .927 & 2.041 .177 & 2.039 .251 & 1.707 .646 & 1.962 .379 & 21.227 .792 \\
\hline $\begin{array}{l}\text { Descapitalização } \\
\text { do banco em réis }\end{array}$ & -1.094 .574 & -927.791 & -924.967 & -922.277 & -1.172 .979 & -785.073 & -763.823 & -930.749 & -662.354 & -677.621 & -8.862 .208 \\
\hline $\begin{array}{l}\text { Dividendo/lucro } \\
\text { divulgado }\end{array}$ & $66,83 \%$ & $71,89 \%$ & $68,46 \%$ & $65,20 \%$ & $64,46 \%$ & $72,01 \%$ & $72,77 \%$ & $68,66 \%$ & $72,05 \%$ & $74,33 \%$ & $69,26 \%$ \\
\hline $\begin{array}{l}\text { Dividendo } \\
\text { ajustado/lucro } \\
\text { divulgado }\end{array}$ & $44,66 \%$ & $51,67 \%$ & $49,27 \%$ & $46,98 \%$ & $41,54 \%$ & $51,86 \%$ & $52,95 \%$ & $47,14 \%$ & $51,92 \%$ & $55,25 \%$ & $48,86 \%$ \\
\hline $\begin{array}{l}\text { Dividendo } \\
\text { real/lucro ajustado }\end{array}$ & $100,00 \%$ & $100,00 \%$ & $95,12 \%$ & $90,49 \%$ & $100,00 \%$ & $100,00 \%$ & $100,00 \%$ & $100,00 \%$ & $100,00 \%$ & $100,00 \%$ & $98,31 \%$ \\
\hline
\end{tabular}

Verificamos que praticamente $100 \%$ do lucro líquido ajustado fora distribuido aos acionistas, fato esse que pode contrastar quando notamos a taxa de $69,29 \%$ utilizando os números reais do efeito acumulado no período analisado. 
Na mesma direção, o banco praticamente fora descapitalizada em $100 \%$ do capital realizado, em época que as instituições financeiras, empresas e agricultores sofriam com a questão do fim do trabalho servil.

Se o conceito de lucro fosse aquele o mais adequado, os dividendos e lucratividade da empresa diminuiriam numa faixa de $27 \%$ no período, o que implicaria numa remuneração menor aos seus acionistas de 8,8 mil contos de réis no decênio e a rentabilidade sobre o patrimônio oscilaria em quedas importantes de 1.96p.p. até 3.59p.p.

As divulgações dos anos 80 continuam as mesmas e interessante o trecho em que o banco fala da segurança quanto aos níveis de remuneração dos acionistas (BB, 1887):

Pelo que respeita á situação geral do Banco, considerada a intensidade de suas operações, os lucros que ellas produzem e as sobras de dividendos remunerados, podemos consideral-a isempta de perigos, não obstante a prolongada crise que atravessamos e cujas consequencias tendem a estender-se no tempo e na acção deprimente dos valores que constituem boa parte, a melhor talvez, da riqueza do paiz. (p. 14).

Com a reorganização do banco em 1902, em que inclusive, como verificamos era acusado e fazia mea culpa acerca de ser um grande distribuidor de capital aos detentores de ações da entidade, a distribuição de dividendos assiste a uma diminuição pequena quando comparada ao lucro daquele observado durante a Monarquia e os primeiros anos, antes da reorganização. Todavia, a taxa acumulada nesse período continua próxima de $90 \%$ em relação ao lucro líquido ajustado, promovendo um desfalque de recursos no montante de 83 mil contos no período e que se comparando com o dividendo que seria pago utilizando a base de cálculo mais apropriada, os acionistas veriam seus recursos diminuírem na ordem de 15 mil contos de réis, conforme evidenciado abaixo: 
Tabela 18 - A distribuição de dividendos comparando os números reais e ajustados nos anos de 1890 a 1900 (em réis-mil)

\begin{tabular}{|c|c|c|c|c|c|c|c|c|c|c|c|c|}
\hline & 1890 & 1891 & 1892 & 1893 & 1.894 & 1.895 & 1.896 & 1.897 & 1.898 & 1.899 & 1900 & $\begin{array}{r}\text { De } 1890 \text { a } \\
1900 \\
\end{array}$ \\
\hline $\begin{array}{l}\text { Lucro líquido } \\
\text { divulgado }\end{array}$ & 6.016 .132 & 12.970 .968 & 15.964 .741 & 4.784 .340 & 12.729 .340 & 11.938 .397 & 10.601 .908 & 11.295 .489 & 9.945 .966 & 9.274 .459 & 9.009 .208 & 114.530 .950 \\
\hline $\begin{array}{l}\text { (-) Costituição de } \\
\text { fundo de reserva }\end{array}$ & 1.510 .547 & 2.328 .676 & 4.000 .000 & 1.909 .401 & 1.909 .401 & 1.790 .760 & 1.590 .286 & 1.694 .323 & 1.491 .895 & 1.396 .169 & 1.351 .381 & 20.972 .839 \\
\hline $\begin{array}{l}\text { (-) Remuneração } \\
\text { dos diretores }\end{array}$ & 66.585 & 157.275 & 159.600 & - & - & - & - & - & - & - & - & 383.460 \\
\hline $\begin{array}{l}\text { (=) Lucro líquido } \\
\text { ajustado }\end{array}$ & 4.439 .000 & 10.485 .018 & 11.805 .141 & 2.874 .939 & 10.819 .939 & 10.147 .638 & 9.011 .622 & 9.601 .166 & 8.454 .071 & 7.878 .290 & 7.657 .827 & 93.174 .650 \\
\hline \multicolumn{13}{|l|}{ Efeitos em \% } \\
\hline $\begin{array}{l}\text { Relativos aos } \\
\text { lucros e } \\
\text { distribuição de } \\
\text { dividendos }\end{array}$ & $-26,22 \%$ & $-19,17 \%$ & $-26,05 \%$ & $-39,91 \%$ & $-15,00 \%$ & $-15,00 \%$ & $-15,00 \%$ & $-15,00 \%$ & $-15,00 \%$ & $-15,05 \%$ & $-15,00 \%$ & $-18,31 \%$ \\
\hline Relativo ao ROE & $-1,25 \%$ & $-1,51 \%$ & $-2,45 \%$ & $-0,78 \%$ & $-0,74 \%$ & $-0,74 \%$ & $-0,69 \%$ & $-1,00 \%$ & $-1,01 \%$ & $-0,96 \%$ & $-0,93 \%$ & $\mathrm{n} / \mathrm{a}$ \\
\hline \multicolumn{13}{|l|}{$\begin{array}{c}\begin{array}{c}\text { Efeitos } \\
\text { absolutos }\end{array} \\
\end{array}$} \\
\hline $\begin{array}{l}\text { Dividendos } \\
\text { divulgados }\end{array}$ & 4.439 .000 & 10.485 .018 & 10.640 .000 & 7.952 .952 & 7.952 .952 & 7.715 .712 & 7.469 .634 & 7.365 .354 & 7.112 .580 & 6.461 .952 & 6.155 .160 & 83.750 .314 \\
\hline $\begin{array}{l}\text { Dividendos } \\
\text { ajustados }\end{array}$ & 3.275 .314 & 8.475 .512 & 7.867 .757 & 4.778 .977 & 6.760 .009 & 6.558 .355 & 6.349 .189 & 6.260 .551 & 6.045 .693 & 5.489 .175 & 5.231 .886 & 68.414 .006 \\
\hline $\begin{array}{l}\text { Descapitalização } \\
\text { do banco em réis }\end{array}$ & -1.163 .686 & -2.009 .506 & -2.772 .243 & -3.173 .975 & -1.192 .943 & -1.157 .357 & -1.120 .445 & -1.104 .803 & -1.066 .887 & -972.777 & -923.274 & -15.336 .307 \\
\hline $\begin{array}{l}\text { Dividendo/lucro } \\
\text { divulgado }\end{array}$ & $73,78 \%$ & $80,83 \%$ & $66,65 \%$ & $166,23 \%$ & $62,48 \%$ & $64,63 \%$ & $70,46 \%$ & $65,21 \%$ & $71,51 \%$ & $69,67 \%$ & $68,32 \%$ & $73,12 \%$ \\
\hline $\begin{array}{l}\text { Dividendo } \\
\text { ajustado/lucro } \\
\text { divulgado } \\
\end{array}$ & $54,44 \%$ & $65,34 \%$ & $49,28 \%$ & $99,89 \%$ & $53,11 \%$ & $54,93 \%$ & $59,89 \%$ & $55,43 \%$ & $60,79 \%$ & $59,19 \%$ & $58,07 \%$ & $59,73 \%$ \\
\hline $\begin{array}{l}\text { Dividendo } \\
\text { real/lucro } \\
\text { ajustado }\end{array}$ & $100,00 \%$ & $100,00 \%$ & $90,13 \%$ & $276,63 \%$ & $73,50 \%$ & $76,03 \%$ & $82,89 \%$ & $76,71 \%$ & $84,13 \%$ & $82,02 \%$ & $80,38 \%$ & $89,89 \%$ \\
\hline
\end{tabular}

A consequência em todos os períodos é uma fatal descapitalização da instituição, com conseguinte menor capacidade de efetuar empréstimos, ainda mais para as classes menos favorecidas, além de agravar os problemas de liquidez persistentes da instituição.

Outrossim, verificamos nesse capítulo como a contabilidade foi usurpada pelo poder dominante em seus conceitos e técnicas para fins materiais, de dominação e de controle social. 


\section{CAPÍTULO 5 - CONSIDERAÇÕES FINAIS E CONCLUSÕES}

O objetivo central do nosso trabalho foi entender através de uma abordagem gramsciana como o Banco do Brasil, entidade palco da união entre sociedade civil e sociedade política brasileira, se utilizou do financial reporting como instrumento de disseminação ideológico do grupo dirigente no período compreendido entre 1853 e 1902.

A análise dos dados permitiram-nos tirar as seguintes conclusões em uma abordagem teórica material, sobretudo da obra gramsciana: (a) a existência de uma interface entre sociedade civil e sociedade política ao seio do Estado Brasileiro com benefícios materiais diretos para as partes; (b) o vinculo orgânico entre a estrutura e a superestrutura; (c) os conflitos entre intelectuais orgânicos e os tradicionais; (d) o transformismo do intelectual rural e de algumas classes subalternas e por fim, (e) o abandono das regiões e classes mais desfavorecidas.

Em relação ao ponto primeiro (a), a interface entre a sociedade civil e a sociedade política se dá além de seus estatutos, com a indicação por parte do governo de presidente e vice em boa parte dos anos bancais, mas também aos auxílios mútuos entre a instituição financeira e os diversos representantes maiores do país, quer na Monarquia ou na República, com os empréstimos a taxas módicas (Capítulo 3.2a), a ideia de que o café era o bem nacional a ser empreendido com todas as forças, notadamente com ajuda pública e da referida instituição financeira (Capítulo 3.1a).

Em relação ao vínculo necessário e orgânico entre estrutura e superestrura (b), novamente é fundamental que a dominação seja mais consentida que imposta na visão gramsciana; assim, nessa visão material, os benefícios que o país teria com os esforços dispendidos com a produção cafeeira (Capítulo 3.1a) elucidam e trazem à tona tal vínculo. O próprio discurso empregado em favor do trabalho servil (Capítulo 3.1d) também é evidência desse vínculo.

No tocante ao conflito entre os intelectuais orgânicos e tradicionais (c), vemos sobretudo nos anos imediatamente anteriores à proclamação da república, com o imenso relatório publicado em 1901/1902 (Capítulo 3.2c) que tentava desqualificar o empreendimento do poder político anterior (e também aos membros civis) quanto à administração do banco e também no tocante a revoltas populares (Capítulo 3.2b), 
sobretudo a Revolta da Armada, representantes do poder ditadorial brasileiro da república da espada, insatisfeitos com a sua não-inclusão no bloco de privilégios que vigorava sob a tutela dos dois primeiros marechais.

Agora em relação aos pontos (d), a tentativa de transformismo do intelectual rural e abandono das classes subalternas (e), foram evidenciadas nos itens acerca do discurso elitista, favorável amplamente aos cargos de alto escalão (Capítulo 3.1c) e também na política que focava o Sudeste, mais favorecida em termos materiais, com linhas deveras superiores que as destinadas especificamente às provincias/estados do Norte, que inclusive tinham a alcunha de "Ajuda" (Capítulo 3.1b). A tentativa de transformismo também é amplamente verificada com a política benévola do banco e do governo para com os pequenos e médios proprietários, sobretudos, os cafeicultores (Capítulo 3.1a).

Adicionalmente o abandono das caixas filiais (Capítulo 3.1b) deixava essas regiões mais desfavorecidas à mercê de capitalistas privados e individuais, sem um banco de alcance e porte nacional, voltado aos interesses mais primeiros do país como nação.

Para a obtenção das conclusões acima, nos permitem inferir que o financial reporting e a contabilidade per si foram apropriados pelo grupo dominante para fins de dominação, através da disseminação ideológica. Tanto através do discurso empregado quanto da manipulação de conceitos contábeis: a contabilidade não deve ser encarada como neutra.

Tanto a causa como a consequencia tem origem na transferência de recursos públicos para o grupo dominante brasileiro, como vimos no Capítulo 4 e que ampliaremos tomando os quase 50 anos de dados.

Agora considerando desde sua fundação de 1853 até 1900, evidenciamos o quadro abaixo, que nos permitem tirar conclusões acerca da dimensão temporal como um todo: 
Tabela 19 - Os efeitos da distribuição de dividendos no Banco do Brasil (1853 - 1900)

\begin{tabular}{|c|c|c|c|c|c|c|c|}
\hline & Anos 1850 & Anos 1860 & Anos 1870 & Anos 1880 & Anos 1890-1900 & De 1853 a 1900 - soma & De 1853 a 1900 -média \\
\hline Lucro líquido divulgado & 15.781 .698 & 42.670 .650 & 47.384 .551 & 43.445 .991 & 114.530 .950 & 263.813 .840 & 52.762 .768 \\
\hline Lucro líquido ajustado & 14.191 .583 & 30.081 .512 & 28.049 .999 & 30.605 .831 & 93.174 .650 & 196.103 .575 & 39.220 .715 \\
\hline Variação (ajustado/divulgado) & $-10,08 \%$ & $-29,50 \%$ & $-40,80 \%$ & $-29,55 \%$ & $-18,65 \%$ & $-25,67 \%$ & $-25,67 \%$ \\
\hline Dividendos divulgados & 14.096 .200 & 30.726 .840 & 28.050 .000 & 30.090 .000 & 83.750 .314 & 186.713 .354 & 37.342 .671 \\
\hline Dividendos ajustados & 12.675 .978 & 21.661 .488 & 16.604 .620 & 21.227 .792 & 68.414 .006 & 140.583 .885 & 28.116 .777 \\
\hline Variação (ajustado/divulgado) & $-10,08 \%$ & $-29,50 \%$ & $-40,80 \%$ & $-29,45 \%$ & $-18,31 \%$ & $-24,71 \%$ & $-24,71 \%$ \\
\hline Dividendo/lucro divulgado & $89,32 \%$ & $72,01 \%$ & $59,20 \%$ & $69,26 \%$ & $73,12 \%$ & $70,77 \%$ & $70,77 \%$ \\
\hline Dividendo real/lucro ajustado & $99,33 \%$ & $102,15 \%$ & $100,00 \%$ & $98,31 \%$ & $89,89 \%$ & $95,21 \%$ & $95,21 \%$ \\
\hline Descapitalização do banco em réis & -1.420 .222 & -9.065 .352 & -11.445 .380 & -8.862 .208 & -15.336 .307 & -46.129 .469 & -9.225 .894 \\
\hline
\end{tabular}

Assim sendo verificamos que com a apropriação da contabilidade e do financial reporting, os acionistas do Banco do Brasil puderam receber um total de mais de 186 mil contos de réis, quase 5 vezes o patrimônio médio no período e aproximadamente $95,21 \%$, quase a totalidade do lucro gerado pela instituição em quase 50 anos.

Se o conceito de lucro fosse mais robusto que aquele adotado pela instituição, os acionistas receberiam menos 46 mil contos, superior a uma vez o patrimônio médio do período, um quarto maior que aquele de fato faturado.

A contabilidade, como técnica social, desenvolvida por e para humanos não é e nunca será neutra. Como pode haver neutralidade em um ambiente de conflito de classes?

A ideologia a ser impregnada não era voltada, como acabamos de ver para o bem público, mas sim para fins de lucro das classes dominantes brasileiras com intuitos claramente hegemônicos e de apropriação do Estado pela sociedade política e civil do século XIX e início do XX.

A própria instituição ou era acusada ou se auto intitulava culpada. Concluindo com último relatório do período de nossa pesquisa (BB, 1902):

D'esses lucros, repartiram-se 32.194:017\$600 em dividendos, isto é, não permaneceram no Banco para revigorar o encaixe; e, sendo a cifra correspondente a taes lucros formada em grande parte por lançamentos de juros em debito de contas mal garantidas, de impraticavel liquidação muitas dellas e que nenhum movimento 
tiveram em largo periodo de tempo; não significando, portanto, essas utilidades, beneficios realizados em numerario, mas alinhamento de algarismo, - conjectura-se a que poderia chegar esse systema de trocar moeda corrente por cifras illusorias em fundos de reservas, titulos em liquidação que exprimiam perdas quasi totaes, contas correntes com garantia de acções e debentures desmarcadamente desvalorisados; em vez de reter esses lucros, mesmo ficticios, para afiançar não só o proprio capital que se ia assim desfalcando, como os depositos consideraveis confiados á sua guarda.

Distribuir dividendos n'estas condições equivale a restituição ou rateios de capital, processo censuravel em um estabelecimento de credito collocado nas apertadas conjecturas de não poder repôr, de um momento para outro, os consideraveis depositos em dinheiro de sua extensa clientela.

(...) concorriam para os beneficios do Banco, eram de resultados negativos e, sobretudo, prejudiciaes, porque sobre elles se faziam calculos para dividendos, operando-se, assim, o escoamento de dinheiro e consequente aggravação de todas as dificuldades (grifo nosso). (p. 23)

Como consideração final e não menos importante, gostaria de destacar que em minha visão o objetivo de qualquer pesquisa que adote a perspectiva gramsciana numa abordagem mais ampla deve ter sempre a práxis como seu objetivo final, evidenciando as condições repressivas a que somos submetidos, fornecendo elementos para a elucidação das contradições, incitando, por fim, a ação (política). E nesse certame essa pesquisa tem a ambição de se encaixar, já que como bem ilustrado por Viotti da Costa (2010):

(...) a despeito das transformações ocorridas entre 1822 e 1889 , as estruturas socioeconômicas da sociedade brasileira não se alteraram profundamente, nesse período, de modo a provocar conflitos sociais mais amplos. O sistema de clientela e patronagem que permeava toda a sociedade minimizou as tensões de raça e classe. $O$ resultado desse processo de desenvolvimento foi a perpetuação de valores tradicionais elitistas, antidemocráticos e autoritários, bem como a sobrevivência de estruturas de mando que implicam a marginalização de amplos setores da população (grifo nosso). (p. 18). 


\section{REFERÊNCIAS}

Alencar, F; Carpi L. \& Ribeiro M. (1994), História da Sociedade Brasileira. Rio de Janeiro: Ed. Ao Livro Técnico.

Alvesson, M. \& Deetz, S. (2000), The Critical Tradition: Critical Theory and Postmodernism, in Doing Critical Management Research, London, Sage, pp. 81-111.

Andrada, A. C. R. (1923), Bancos de emissão do Brasil. Rio de Janeiro: Liv. Leite Ribeiro.

Arnold, P. J. (2012). The political economy of financial harmonization: The East Asian financial crisis and the rise of international accounting standards. Accounting, Organizations and Society, 37(6), 361-381.

Arrington, C.E., \& Watkins, A. L. (2002), Maintaining 'critical intent' within a postmodern theoretical perspective on accounting research. Critical Perspectives on Accounting, 13(2), 139-157.

Aversari Martins, E. A. (2012). Pesquisa contábil brasileira: uma análise filosófica. Tese de doutorado. Faculdade de Economia, Administração e Contabilidade, Universidade de São Paulo.

Banco do Brasil (2010), História do Banco do Brasil. Belo Horizonte: UFJF. (1854). Relatório Anual do Exercício de 1854. Rio de Janeiro. Brasil. 
(1855). Relatório Anual do Exercício de 1855. Rio de Janeiro.

Brasil.

(1856). Relatório Anual do Exercício de 1856. Rio de Janeiro.

Brasil.

(1857). Relatório Anual do Exercício de 1857. Rio de Janeiro.

Brasil.

(1858). Relatório Anual do Exercício de 1858. Rio de Janeiro.

Brasil.

(1859). Relatório Anual do Exercício de 1859. Rio de Janeiro.

Brasil.

(1860). Relatório Anual do Exercício de 1860. Rio de Janeiro.

Brasil.

(1861). Relatório Anual do Exercício de 1861. Rio de Janeiro.

Brasil.

(1862). Relatório Anual do Exercício de 1862. Rio de Janeiro.

Brasil.

(1863). Relatório Anual do Exercício de 1863. Rio de Janeiro.

Brasil. 
(1864). Relatório Anual do Exercício de 1864. Rio de Janeiro. Brasil.

(1865). Relatório Anual do Exercício de 1865. Rio de Janeiro.

Brasil.

(1866). Relatório Anual do Exercício de 1866. Rio de Janeiro.

Brasil.

(1867). Relatório Anual do Exercício de 1867. Rio de Janeiro.

Brasil.

(1868). Relatório Anual do Exercício de 1868. Rio de Janeiro.

Brasil.

(1869). Relatório Anual do Exercício de 1869. Rio de Janeiro.

Brasil.

(1870). Relatório Anual do Exercício de 1870. Rio de Janeiro.

Brasil.

(1871). Relatório Anual do Exercício de 1871. Rio de Janeiro.

Brasil.

(1872). Relatório Anual do Exercício de 1872. Rio de Janeiro.

Brasil. 
(1873). Relatório Anual do Exercício de 1873. Rio de Janeiro.

Brasil.

(1874). Relatório Anual do Exercício de 1874. Rio de Janeiro.

Brasil.

(1875). Relatório Anual do Exercício de 1875. Rio de Janeiro.

Brasil.

(1876). Relatório Anual do Exercício de 1876. Rio de Janeiro.

Brasil.

(1877). Relatório Anual do Exercício de 1877. Rio de Janeiro.

Brasil.

(1878). Relatório Anual do Exercício de 1878. Rio de Janeiro.

Brasil.

(1879). Relatório Anual do Exercício de 1879. Rio de Janeiro.

Brasil.

(1880). Relatório Anual do Exercício de 1880. Rio de Janeiro.

Brasil.

(1881). Relatório Anual do Exercício de 1881. Rio de Janeiro.

Brasil. 
(1882). Relatório Anual do Exercício de 1882. Rio de Janeiro. Brasil.

(1883). Relatório Anual do Exercício de 1883. Rio de Janeiro. Brasil.

(1884). Relatório Anual do Exercício de 1884. Rio de Janeiro. Brasil.

(1885). Relatório Anual do Exercício de 1885. Rio de Janeiro. Brasil.

(1886). Relatório Anual do Exercício de 1886. Rio de Janeiro. Brasil.

(1887). Relatório Anual do Exercício de 1887. Rio de Janeiro. Brasil.

(1888). Relatório Anual do Exercício de 1888. Rio de Janeiro.

Brasil.

(1889). Relatório Anual do Exercício de 1889. Rio de Janeiro.

Brasil.

(1890). Relatório Anual do Exercício de 1890. Rio de Janeiro. Brasil. 
(1891). Relatório Anual do Exercício de 1891. Rio de Janeiro.

Brasil.

(1892). Relatório Anual do Exercício de 1892. Rio de Janeiro.

Brasil.

(1893). Relatório Anual do Exercício de 1893. Rio de Janeiro.

Brasil.

(1894). Relatório Anual do Exercício de 1894. Rio de Janeiro.

Brasil.

(1895). Relatório Anual do Exercício de 1895. Rio de Janeiro.

Brasil.

(1896). Relatório Anual do Exercício de 1896. Rio de Janeiro.

Brasil.

(1897). Relatório Anual do Exercício de 1897. Rio de Janeiro.

Brasil.

(1898). Relatório Anual do Exercício de 1898. Rio de Janeiro.

Brasil.

(1899). Relatório Anual do Exercício de 1899. Rio de Janeiro.

Brasil. 
(1900). Relatório Anual do Exercício de 1900. Rio de Janeiro. Brasil.

(1901). Relatório Anual do Exercício de 1901. Rio de Janeiro. Brasil.

(1902). Relatório Anual do Exercício de 1902. Rio de Janeiro. Brasil.

Baker, C.R. \& Bettner, M.S. (1997), "Interpretive and Critical Research in Accounting: A Commentary on its Absence from Mainstream Accounting Research", Critical Perspectives on Accounting, 8(4), 293-310.

Bianchi, A. (2008), O laboratório de Gramsci: Filosofia, História e Política. São Paulo: Ed. Alameda.

Boto, C. (1994), Nova história e seus velhos dilemas. Revista USP, São Paulo, 30(23), $23-33$.

Burke, P. (1992), A escrita da história. São Paulo: Ed. UNESP.

Cardoso, J.L. (2010), A new contribution to the history of Banco do Brasil (1808 1829): chronicle of a foretold failure. Revista Brasileira de História, São Paulo, $30(59), 165-189$.

Carmona, S., Ezzamel, M. \& Gutiérrez, F. (2004), Accounting history research: traditional and new accounting history perspectives, Revista Española de Historia de la Contabilidad, 1, 24-53. 
Carnegie, G.D, \& Napier, C.J. (2012), Accounting's past, present and future: the unifying power of history. Accounting, Auditing \& Accountability Journal Review, 25(2), 328-369.

Carvalho, C. (1912), Tratado elementar de Contabilidade, Rio de Janeiro: Ed. Curiosidades.

Chua, W. F. (1986a), Radical developments in accounting thought. The Accounting Review, 61(4), 601-632.

(1986b), Theoretical constructions of the real. Accounting, Organizations and Society, 11(6), 583-598.

Clarke, C., G. Dean, \& K. Oliver. (2003), Corporate Collapse: Regulatory, Accounting, and Ethical Failure. Melbourne, Australia: Cambridge University Press.

Covaleski, M.A. \& Dirsmith, M.W. (1990), Dialectic tension, double reflexivity and the everyday accounting researcher: on using qualitative methods. Accounting, Organizations and Society, 15(6), 543-573.

Costa Neto, Y. C. C. N.. (2004), Bancos de emissão no Brasil. Brasília: Banco Central do Brasil.

Crook, M. (2008), Finding the stories, Telling the Story In Kouritzin Sandra G., Piquemal, Nathalie A.C., Norman, Renee, Qualitative Research: challenging the orthodoxies in standard academic discourse(s), Abingdon, Routledge.

Crotty, M. (1998), The foundations of social research. Crow Nest: Allen \& Unwin. 
Gramsci (1999). In: Coutinho, C. N., A. Cadernos do Cárcere. Rio de Janeiro: Civilização Brasileira.

Fernandes, F. (1972), O negro no mundo dos brancos. São Paulo: Difel

Fiore, G. (1979), A vida de Antonio Gramsci. Rio de Janeiro: Paz e Terra

Furtado, C. (2007), Formação econômica do Brasil. 22a ed., São Paulo: Cia Editora Nacional.

Gambi, T. F. R (2010), O banco da ordem: política e finanças no império brasileiro. Tese de doutorado. Faculdade de Filosofia, Letras e Ciências Humanas, Universidade de São Paulo.

Gramsci, A. (1999), Cadernos do cárcere. Rio de Janeiro: Civilização Brasileira, 2000 .

Gruppi, L. (1978), O conceito de hegemonia em Gramsci. Rio de Janeiro: Graal.

Hines, R. (1986), Why won't the FASB's conceptual framework work?, Working Paper.

(1987), The social roles and consequences of financial accounting, Working Paper.

(1988), Financial Accounting: in communicating reality, we construct reality, Accounting, Organizations and Society, 13(3), 251-261. 
(1991), The FASB's conceptual framework, financial accounting and the maintenance of social world, Accounting, Organizations and Society, 16(4), 313-331.

Hobsbawn, E. (2005), A era dos impérios. Rio de Janeiro: Paz e Terra.

Holanda, S. B. (1995), Raízes do Brasil. São Paulo: Companhia das Letras.

IASB, (2016), Framework for the preparation and presentation of financial statements. Londres: IASCF Publications Department.

Lamounier, M. (2007), Entre a Escravidão e o Trabalho Livre. Escravos e Imigrantes nas Obras de Construção das Ferrovias no Brasil no Século XIX, Economia Selecta, 9(4), 215-245.

Laughlin, R. (1995), Empirical research in accounting: algternative approaches and a case for 'middle-range'thinking. Accounting, Auditing \& Accountability Journal, 8(1), 63-87.

Lee, T. (2006), The FASB and accounting for economic reality, Accounting and the Public Interest, 6(1), 1-27.

Macintosh, N. B. (2006), Commentary - Accounting - Truth, Lies or "Bullshit"? A philosophical Investigation, Accounting and the Public Interest, 6(1), 22-36.

Martins, J. S. (1986), O cativeiro da terra. São Paulo: Ed. Contexto 
Marx, K. (1999), Para a crítica da economia política. In: Série Os pensadores - Karl Marx, São Paulo: Ed. Nova Cultural

Melo Franco, A. A. (1947), História do Banco do Brasil. São Paulo: Ed. Instituto de Economia da Associação Comercial.

Merino, B. D. (1998), Critical theory and accounting history. Critical Perspectives on Accounting, 9(6), 603-616.

Morgan, G. (1988), Accounting as Reality Construction: Towards a New Epistemology for Accounting Practice, Accounting, Organizations and Society, $13(5), 477-485$

Most, K. (1979), Accounting Theory. Washington, DC: Grid Pub.

Neimark, M. (1990), The king is dead. Long live the king. Critical Perspectives on Accounting, 1(1), 103-104.

Netto, A. D. (2009), O Problema do Café no Brasil. São Paulo: Ed. UNESP.

Nogueira, M. A. (2003), Sociedade civil, entre o político-estatal e o universo gerencial. Rev. Brasileira de Ciências Sociais, 18(52), 185-202.

Orwell, G. (2009), 1984. São Paulo: Siciliano.

Pacheco, C. (1973), História do Banco do Brasil. São Paulo: Ed. Instituto de Economia da Associação Comercial. 
Parker, L. D. (2007), Financial and external reporting research: the broadening corporate governance challenge. Accounting and Business Research, 37(1), 3954.

Portelli, H. (1977), Gramsci e o Bloco Histórico. Rio de Janeiro: Paz e Terra.

Prado Jr, C. (2012), História Econômica do Brasil. São Paulo: Ed. Brasiliense.

Prasad, P. (2005), Crafting Qualitative Research. Newburk Park, CA: Sage.

Quintaneiro, T.; Barbosa, M.L.O. \& Oliveira (2012), Um toque de clássicos. Belo Horizonte: Ed. UFMG.

Raphael de Carvalho, E. (1987), A Metafisica da Contabilidade Comercial, São Luis: Edição fac - símile.

Ribeiro, J.M. (2009), A importância do bloqueio continental para o futuro de Portugal e do Brasil. Revista Faculdade de Letras e História, III(10), 63 - 69.

Ricardino, A. \& Iudícibus, S. (2002), A primeira lei das sociedades anônimas no Brasil: lei $\mathrm{n}^{\circ} 1.083$ - 22 de agosto de 1860, Revista de Contabilidade e Finanças, 13(29), 7-25.

Saez, H. E. L (2008). Nas asas do Dédalo: um estudo sobre o meio circulante no Brasil entre os anos de 1840 e 1853. Tese de doutorado. Faculdade de Filosofia, Letras e Ciências Humanas, Universidade de São Paulo.

Secco, L. (2006), Gramsci e a Revolução. São Paulo: Alameda. 
Silva, A. F. (2005). A contabilidade brasileira no século XIX:- leis, ensino e literatura. Dissertação de mestrado. Pontifícia Universidade Católica de São Paulo.

Souza, S. D. (1994). Cédulas brasileiras. São Paulo: Amato.

Souza Franco, B. (1848 1ed), Os Bancos do Brasil. Brasília: UNB.

Tinker, A. (1988), Panglossian accounting theories: the science of apologizing in style. Accounting, Organizations and Society, 13(2), 165- 169.

Viotti da Costa, E. (2010), Da Monarquia á República. São Paulo: Ed. UNESP.

Vianna, L. W. \& Carvalho, M. A. R. República e civilização brasileira. In: Bignotto, N. (Org.). Pensar a República. Belo Horizonte: Ed. UFMG, 2000.

Watts, R. L., \& Zimmermann, J. L. (1990), Positive accounting theory: a ten year perspective. The Accounting Review, 65(1). 131-156. 